\title{
SOLAR ENERGY SYSTEM CASE STUDY: TELEX COMMUNICATIONS Blue Earth, Minnesota
}

September 1984
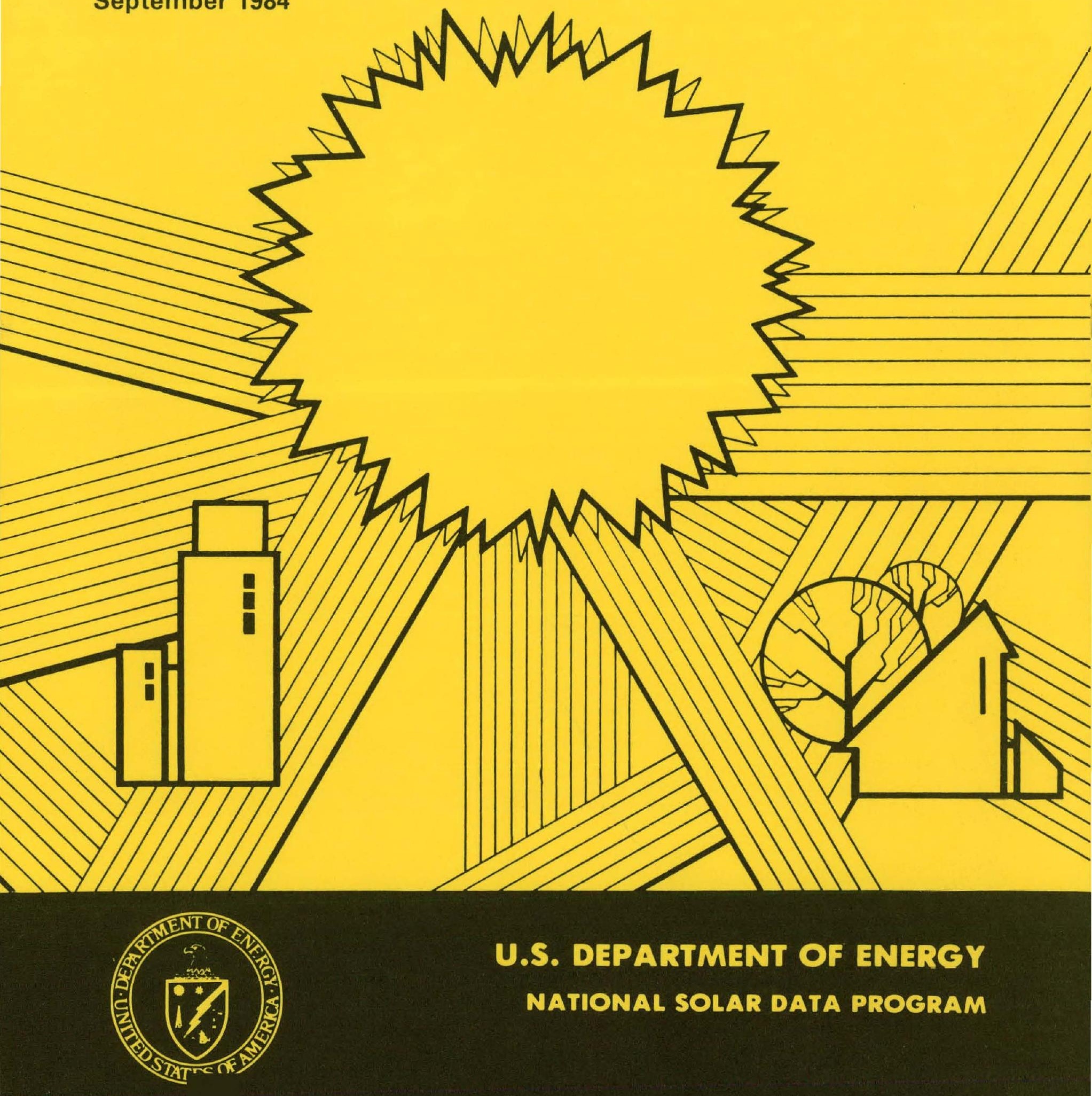

U.S. DEPARTMENT OF ENERGY NATIONAL sOlaR data PROgRaM 


\section{DISCLAIMER}

This report was prepared as an account of work sponsored by an agency of the United States Government. Neither the United States Government nor any agency Thereof, nor any of their employees, makes any warranty, express or implied, or assumes any legal liability or responsibility for the accuracy, completeness, or usefulness of any information, apparatus, product, or process disclosed, or represents that its use would not infringe privately owned rights. Reference herein to any specific commercial product, process, or service by trade name, trademark, manufacturer, or otherwise does not necessarily constitute or imply its endorsement, recommendation, or favoring by the United States Government or any agency thereof. The views and opinions of authors expressed herein do not necessarily state or reflect those of the United States Government or any agency thereof. 


\section{DISCLAIMER}

Portions of this document may be illegible in electronic image products. Images are produced from the best available original document. 


\section{DISCLAIMER}

This report was prepared as an account of work sponsored by an agency of the United States Government. Neither the United States Government nor any agency thereof, nor any of their employees, makes any warranty, express or implied, or assumes any legal liability or responsibility for the accuracy, completeness, or usefulness of any information, apparatus, product, or process disclosed, or represents that its use would not infringe privately owned rights. Reference herein to any specific commercial product, process, or service by trade name, trademark, manufacturer, or otherwise does not necessarily constitute or imply its endorsement, recommendation, or favoring by the United States Government or any agency thereof. The views and opinions of authors expressed herein do not necessarily state or reflect those of the United States Government or any agency thereof.

This report has been reproduced directly from the best available copy.

Available from the National Technical Information Service, U. S. Department of Commerce, Springfield, Virginia 22161.

Price: Printed Copy A10

Microfiche A01

Codes are used for pricing all publications. The code is determined by the number of pages in the publication. Information pertaining to the pricing codes can be found in the current issues of the following publications, which are generally available in most libraries: Energy Research Abstracts (ERA); Government Reports Announcements and Index (GKA and I); Scientific and Technicul Abstruct Reports (STAR); and publication NTIS-PR-360 available from NTIS at the above address. 
SOLAR/0011-84/01

(DE85002140)

Distribution Category UC-59A

\author{
SOLAR ENERGY SYSTEM CASE STUDY \\ TELEX COMMUN I CATI ONS \\ BLUE EARTH, MINNESOTA
}

Prepared by:
M.G. Raymond

Approved by:

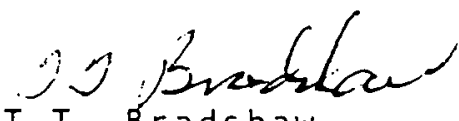

T.T. Bradshaw Program Manager

\author{
Vitro Corporation \\ 14000 Ccorgia Avenue \\ Silver Spring., Maryland 20910
}

The National Solar Data Network

Department of Energy Contract Number DE-ACO1-79CS30027 


\section{EXECUTIVE SUMMARY}

A study is made of a solar energy system for space heating a 97,000square-foot office, factory, and warehouse building owned by Telex Communications, Inc. in Blue Earth, Minnesota. The solar system has 11,520 square feet of ground-oriented flat-plate collectors and a 20,000-gallon storage tank inside the building. Freeze protection is by drainback. Solar heated water from the storage tank circulates around the clock throughout the heating season to heating coils in the ducts. The system achieves its design solar fraction, is efficient, and generally reliable, but not cost-effective.

Performance data for the solar system was collected by the National Solar Data Network for three heating seasons from 1978 to 1981.

Because of a freeze-up of the collector array in December 1978, the solar system was only partially operational in the 1978-1979 heating season. The data in this report was collected in. the 1979-1980 and 1980-1981 heating seasons. Highlights of the performance of the solar system during the above heating seasons are:

- The collector array performance was excellent. The efficiency of the large array was equal to single-panel ASHRAE test results throughout the monitoring period. The operational collector efficiency was $44 \%$. Overall collector efficiency was much lower, only $22 \%$. This is because the collectors did not need to operate full-time in the spring and fall to keep the storage tank hot, and also because the operation of the collector control was conservative to keep the collectors from operating when the possibility of freezing existed. (The collector fluid is water.)

- The solar space heating loop delivered $95 \%$ of the collected solar energy to the load $(86 \%$ through the pipes, nine percent from storage losses). The space heating loop ran continuously throughout the heating season with no minimum temperatures. The temperature of the solar heated water seldom fell below $75^{\circ} \mathrm{F}$, but it did circulate at temperatures as low as $58^{\circ} \mathrm{F}$ after an extended period of cloudy weather.

- There were two major problems encountered with the solar system:

- Two rows of collectors froze on December 2-3, 1978. Improper heat-taping and insulation of the air vents and vacuum breakers resulted in freezing of these devices under near-zero temperatures, preventing the system from draining.

- The original hose connections between the internally manifolded collectors slipped frequently due to thermal expansion and contraction, resulting in leaks. This problem was solved by changing the hose to a type with a hump at its midsection which acts as an expansion compensator. 
These problems were repaired by the fall of 1979, and have not recurred since then. Maintenance has been confined to the occasional tightening of clamps on the hoses connecting the collector manifolds.

- The design solar fraction was $70 \%$ (some documents list a figure of $60 \%$ ). The measured solar fraction for the two heating seasons combined was $66 \%$. No data was collected in two months that undoubtedly had higher solar fractions.

- The solar system was turned off during the summer months, and stagnation temperatures reached $330^{\circ} \mathrm{F}$ on the collector absorber plate. The high stagnation temperatures caused no harm.

- The liel ciecerieal eneigy savings from the solar system amounced to bly million BTU, or 152,000 kwh per season. This is equivalent to $\$ 7,600$ saved at the 1980 rate of $\$ 0.05$ per kwli. Tlie sular syscem cost $\$ 460,000$ to build in 1.977 .

- Weather conditions were about equal tin the long-term aver= age for Rochester, Minnesota. The average insolation was 1,127 BTU/ft2-day over the three heating seasons from 1978 to 1981. Conditions were often bitterly cold. In January 1979, the temperature dropped below zero on 24 days out of 31 , and averaged $00 \mathrm{~F}$ for the month. 
EXECUTIVE SUMMARY

TABLE OF CONTENTS

LIST OF ILLUSTRATIONS

LIST OF TABLES

I INTRODUCTION

2 BUILDING DESCRIPTION 3

2.1 Location 3

2.2 System Description 4

2.3 Operational Modes 15

2.4 Pipes 15

2.5 Pumps 15

3 SYSTEM PRELIMINARY DESIGN ? $\quad 17$

$\begin{array}{lll}3.1 & \text { Requirements } & 17\end{array}$

3.2 Description 17

3.3 Performance Estimates 17

3.4 Operating Mode Analysis 19

3.5 Cost Estimates 19

3.6 Reliability 20

4 SUBSYSTEM PRELIMINARY DESIGN

4.1 Collector 21

4.2 Storage 21

4.3 Heating 22

4.4 Piping . 23

4.5 Pumps 23

4.6 Controls 23

5 ECONOMIC ANALYSIS $\quad 25$

6 DESIGN REVIEWS AND REVISIONS 27

$\begin{array}{ll}6.1 & \text { National Aeronautics and Space } \\ \text { Administration Design Review } & 27\end{array}$

$\begin{array}{lll}6.2 & \text { Final Design Review } & 27\end{array}$

\begin{tabular}{l|l}
7 & FINAL DESIGN
\end{tabular}

$\begin{array}{lll}7.1 & \text { System Description } & 29\end{array}$

$\begin{array}{lll}7.2 & \text { Key Design Trade-Offs } & 30\end{array}$

7.3 Lessons Learned 32 
TABLE OF CONTENTS

(Continued)

Section

Page

8 CONSTRUCTION

8.1 Details and As-Built Changes

8.2 Construction Phase

8.3 Cost

33

34

34

9 ACCEPTANCE TESTING $\quad 45$

9.1 Test. Plan 45

9.2 Test Results $46^{9}$

9.3 System Startup Problems 48

10 SYSTEM THERMAL PERFORMANCE 51

10.1 Solar System 51

10.2 Predicted Versus Actual 54

10.3 Solar Subsystem 56

10.4 Energy Savings $\quad 68$

10.5 Environmental Conditions 69

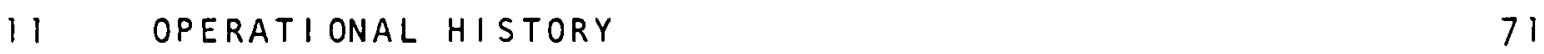

11.1 System 71

11.2 Collection Subsystem Operational History 72

11.3 Storage Subsystem Operational History 74

11.4 Heating Subsystem Operational History 16

12 ECONDMIS. ANAI.YSIS

1.2.1 Design . 79

12.2 Construction 79

12.3 System Startup' 80

12.4 Operaliun dild Maillellalle 80

12.5 Subsidies and Incentiveș 80

$\begin{array}{lll}13 & \text { REFERENCES } & 81\end{array}$

Appendix

A National Solar Data Network Programmatic

Information A-I

B Preliminary Design Drawings B-

C Final Drawings c -1 
TABLE OF CONTENTS

(Continued)

Appendix

Page

D Contract Pricing Proposal from the InterTechnology Corporation Proposal, November 26. 1975

E Thermal Performance Models, TRNSYS Simulation of Original Design of Telex Communications Solar System at Blue Earth, Minnesota by 1 BM Corporation

F Design Review Comments

G Technical Specifications

$G-1$

H Performance Factors and Solar Terms

$\mathrm{H}-\mathrm{I}$ 
Figure

Number

1 Telex Communications Building, South View

2 Telex Communications Solar Energy System Flow Schematic

is

3

4 Collector Row 5, with Pyranometer

5 Collector Hose Connection

6

Title June 9 and 26,1978 $1979-1981$ Collector outlet and Inlet, and outdoor Temperatures, Telex Communications, January 29, 1981 January 1981

Page 


\section{LIST OF ILLUSTRATIONS \\ (Continued)}

Figure

Number

A-1 Schematic Diagram of the NSDN Teleprocessing Network

A-2 Instrumentation, Monitoring and Analysis

Process

A-3 Site Study - Generates Instrumentation Requirements and Performance Evaluation Equations

$A-4$

$A-5$

$A-6$

$A-7$

$A-8$

$A-9$

$A-10$

SDAS Unit Mounted on Wall

SDAS Without Cover

SDAS with the Associated Electrical Junction Box

Eppley Pyranometer Mounted in the Plane of the Solar Collectors

Electrical Power Sensor with Current Sensor Coil Used to Monitor Operational Energy

Résistance Thermal Devices (RTD)

Hersey Totalizing Flow Meters

A-11 WeatherMeasure Wind Speed and Direction Vane and Ambient Air Temperature Sensor

A-12 Junction-Box Mounted on Plywood Sheet Mounted on Masonry Wall

A-13 Energy Flow Diagram for Telex Lommulcatiuls, $1979-1981$

A-14 Monthly Report: January 1981; Site Summary:

Telex Communications

B-1 Preliminary Design Drawing, Telex Communications, Floor Plan and Collector Array Layout

B-2. Preliminary Design Drawing, Telex Communications, Flow Diagram, Collector Row, Storage Tank, Piping

C-1 Final Drawing, Telex Communications, Site/Key

Plan, General Notes
Page

$A-2$

$A-3$

$A-4$

A- 6

A -6

A-7

A- 7

A- 7

A -8

A- 8

A- 8

$A-9$

$A-11$

$A-12$

B - I

B -2

$c-1$ 


\section{LIST OF ILLUSTRATIONS \\ (Continued)}

Figure Number

C-2 Final Drawing, Telex Communications, Solar Heating System, Pier Layout, Framing Plan, and Details

C-3 Final Drawing, Telex Communications, Solar Heating System, Collector Support Details

C-4 Flnal Drawing, Telex Communications, Solar Heating System, Typical Row Elevation and Délals

C-5 Final Drawing, Telex Communications, solar Heating System, Storage Tank Plan and Sections

C-6 Final Drawing, Telex Communications, Solar Heating System, Floor Plan and Collector Array Layout

C-7 Final Drawing, Telex Communications, Solar Heating System, Collector and Storage Sections and Flow Diagram

$c-8$

Final Drawings, Telex Communications, Solar Heating System. Details and Schedules

C-9 Final Drawing, Telex Communications, Solar Heacling System, Underground Collector Pipe Details and Display Panel

C-10 Final Drawings, Telex Communications, Solar Heating System, Storage Tank and Emergency Sump Pump Details
Page

$c-2$

$c-3$

$6-4$

$c-5$

$c-6$

$c-7$

$c-8$

$c-10$ 


\section{LIST OF TABLES}

Table

Number

Heating Coil Schedule, Telex Communications

Title

Page

15 June 9, 1978 Acceptance Test Data, Telex Communications

$$
\text { Support Structure Category Costs, Telex }
$$

16 June 26,1978 Acceptance Test Data, Telex Communications

17 Solar System Thermal Performance, Telex Communications, 1979-1980 Heating Season

18 Solar System Thermal Performance, Telex Communications, 1980-1981 Heating Season

19 Building Load Calculated by the UACd Method, Telex Communications; 1978-1979 Heating Season 


\section{LIST OF TABLES \\ (Continued)}

Table

Number

20 Building Load Calculated by the UACd Method, Telex Communications, 1979-1980 Heating Season

21 Building Load Calculated by the UACd Męthod, Telex Communications, 1980-1981 Heating Season

22 Collection Subsystem Performance, Telex Communications, 1977-1380 Hra! ing Soason

23 Cullecliull Subsystein Hertormance, Telex CommunicaLiuns, 1980-iy8। Heating Season

24 Storage Subsystem Performance, Telex Communications, 1979-1980 Heating Season

25 Storage Subsystem Performance, Telex Communications, 1980-1981 Heating Season

26 Space Heating Subsystem Performance, Telex Communications, 1979-1980 Heating Season

27 Space Heating Subsystem Performance, Telex Communications, 1980-1981 Heating Season

27 b Space Heating Subsystem Performance, Telex Communications, 1980-1981 Heating season (lisntinued)

28 Solur Operatiny Energy, Telex Lommunications, 1979-1980 Heating Season

29 Solar Operating Energy, Telex Communications, 1980-1981 Heating Season

30 Coefficient of Performance, Telex Communications, 1979-1980 Heating Season

31 Cocfficient ur Per rurmance, Telex Communications, 198n-1981 Heating Scninn

32 Energy Savings, Telex Communications, 1979-1980 Heating Season

33 Energy Savings, Telex Communications, 1980-1981 Heating Season

34 Weather Conditions, Telex Communications, 1978-1979 Heating Season 
LIST OF TABLES

(Continued)

Table

Number

35 Weather Conditions, Telex Communications, 1979-1980 Heating Season

36 Weather Conditions, Telex Communications, 1980-1981 Heating Season

37 Storage Water Chemical Analysis, Telex

Communications, February 4, 1981

38 Total System Construction Cost Summary, Telex Commun icat $i$ ons 
SECTION I

INTRODUCTION

Several of the solar systems monitored by the National Solar Data Network (NSDN) have been selected for "case studies," an in-depth history and analysis. This report is a study of the solar system at Telex Communications, Inc., a large space heating system for a 97,000-square-foot office, factory, and warehouse building in Blue Earth, Minnesota. The solar system was designed by InterTechnology/Solar Corporation of Warrenton, Virginia. Mankato Plumbing and Heating Co. began construction in August 1977.

The solar system is large but not complex, with ten rows of singleglazed black chrome flat-plate collectors ( $11,520 \mathrm{ft}^{2}$ ) mounted on wood trusses and concrete piers four feet off the ground about 200 feet from the building. Freeze protection is by drainback to the storage tank. The drainback is complicated by the fact that the storage tank is higher than the collectors (originally the tank was to be buried at the north end of the array, but cost considerations forced its removal to the building). A sump is used to drain the collectors and a sump pump is used to transfer the water from the sump to the storage tank. The sump and its pump are used throughout the collection. All the solar heated water passes through the sump. The sump was disliked by the design reviewers, who felt that it should be bypassed during normal operation, but the designers rejected the reviewers' advice because they believed the automatic valves necessary to bypass the sump would be an unwarranted complication and might interfere with a reliable drainback. The drainback system was chosen in the first place because of its simplicity and reliability. The drainback system and the sump have proved to be reliable, although there was a freeze-up of two collector rows when these rows did not drain in near-zero weather in December 1978. The cause of the freeze-up was traced to air vents and vacuum breakers that were not properly heat-taped and insulated. Water froze in the vents, and the rows did not drain. When the collectors were repaired, standpipes were installed in the outlet pipes of all ten rows. No drainback problems have occurred since this time (as of the summer of 1984).

The solar heating loop was also quite simple; the load pump ran constantly throughout the heating season, circulating heated water to the load heat exchangers which were in the ducts upstream of the electric resistance heaters. This continuous circulation kept the tank well mixed. The collector water return and heating system supply pipes are located very close to each other at the top of the south end of the tank. This design allows collector return water to circulate directly to the load. There was a load bypass line controlled by the demand of the heating coils; as demand dropped, more water went through the bypass, maintaining a constant pressure at the pump outlet. This scheme worked very well; water circulated constantly through the tank as there was no minimum temperature for circulation. Although the temperature of the solar supply water 
fell as low as $580 \mathrm{~F}$ after an extended period of cloudy weather, it did not usually go below $75^{\circ} \mathrm{F}$. The heat was still useful down to these temperatures because it was warmer than the mixture of room and outside air entering the fan coil units.

In short, the solar system is well designed, simple, and efficient, one of the best performers monitored by the National Solar Data Network (NSDN). However, the system cost $\$ 460,000$ to build, and saves less than two percent of that figure per year.

After the monitoring period ended, the system was modified to allow preheating of domestic hot water in the summertime. It is not known whether the savings from this mode of operation are larger than the energy consumed to run the collector pumps in the summer. 


\section{I LOCATION}

The Telex Communications plant is located in southern Minnesota near the town of Blue Earth, at a latitude of 43.6 degrees north. The plant manufacturers tape recorders and other electronic equipment. The 97,000-square-foot building houses administrative offices, assembly areas, and warehouse space. The building is of steel construction with six inches of $\mathrm{fiberglass}$ insulation between the steel skins. The design equipment heating load was 2,600 BTU annually, or 3.35 BTU/ft 2 floor area-heating degree-day. This does not include 2.5 watts/ft 2 of heat supplied by internal lighting, or internal gains from equipment or people. The design UA coefficient is 7,293 BTU/hr-OF. The storage areas are separated from the manufacturing areas with partitions, and the storage areas are maintained at $55^{\circ} \mathrm{F}$, while the work areas are maintained at $68^{\circ} \mathrm{F}$ during the heating season. During cold weather, the space heating load ranges between nine to $12 \mathrm{milli}$ on BTU per day. The average number of heating degree-days for the Blue Earth area is approximately 8,000 . Heat for the building is provided by electric duct heaters mounted in the air-handling units and electric unit heaters. There is very little hot water demand, since none of the manufacturing operations require hot water.

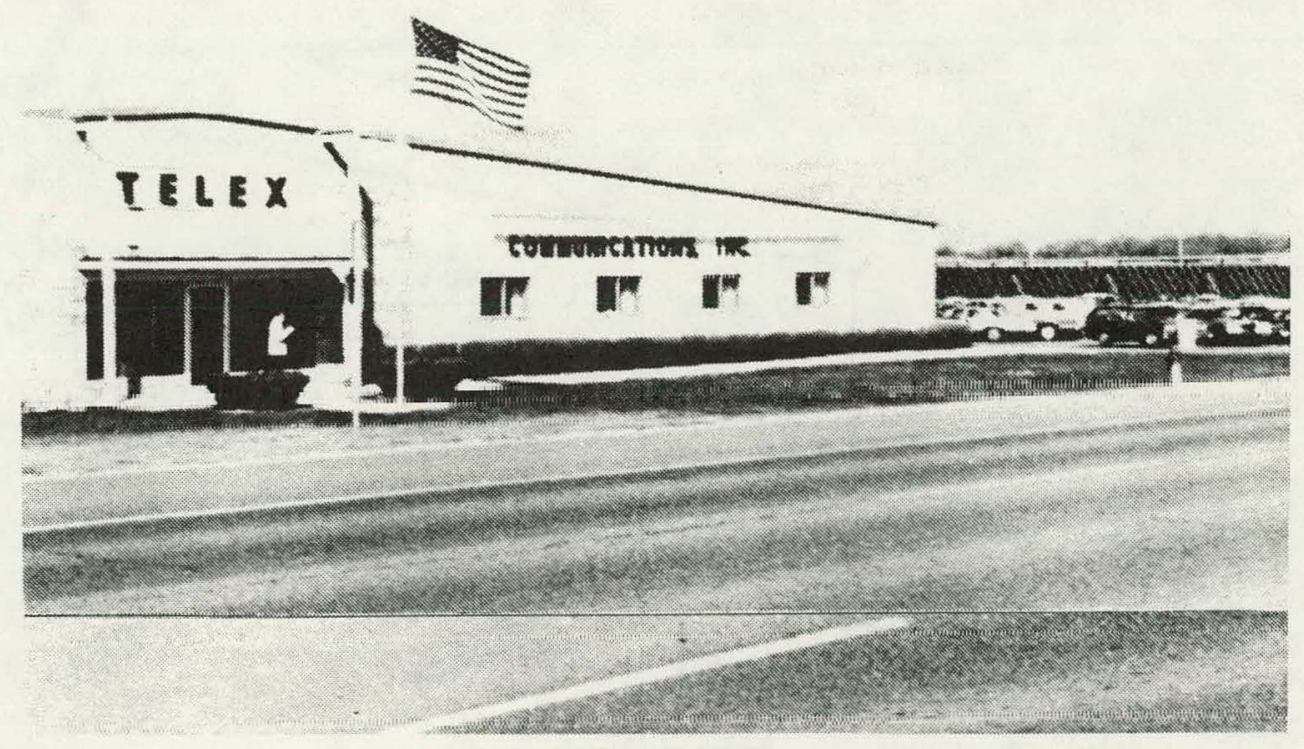

Figure 1. Telex Communications Building, South View

Because of the use of electric resistance heating, the Telex Communications plant was considered a good choice for a solar heating retrofit. A proposal for a solar system was submitted under the PON-l Solar Heating and Cooling Commercial Demonstration Program. 
in June of 1976, Telex Communications was awarded a contract by ERDA (now the Department of Energy) to construct a solar space heating system. InterTechnology/Solar Corporation began the design of the system. in August 1976. Construction of the system by Mankato Plumbing began in August 1977. The system began delivering space heating in February 1978.

\subsection{SYSTEM DESCRIPTION}

The solar energy system is a retrofit, designed to provide $70 \%$ of the annual space heating requirement for the building. Figure 2 is a flow schematic of the Telex Communications solar system. The $11,520-s q u a r e-f o o t$ array of flat-plate collectors is ground-mounted in a field approximately 200 feet east of the building (see Figure 3 ). The array has 10 rows with 36 four-foot by eight-foot collectors in each row. The $20,000-g a l i o n$ storage tank is lucated inside the building. Two 240-gallon-per-minute pumps are used in series to transfer the water from the tank to the collectors, back to a sump, and then from the sump back into the tank. Pre-insulated four-inch copper pipe is buried five feet below-grade to transfer the water to and from the collector field. A pump, with 140-gallonper-minute capacity, is used to draw the heated water from the storage tank, pass it through the coils in the air-handling units, and then return the water to the storage tank. A second load pump is used as a backup; the two pumps do not run together. The only heat exchangers in the system are the air-to-water coils in the airhandling units. Auxiliary heat is provided by electrical resistance heaters in each air-handling unit and by three electrical space heaters. The air-handling units provide ventilation year-round.

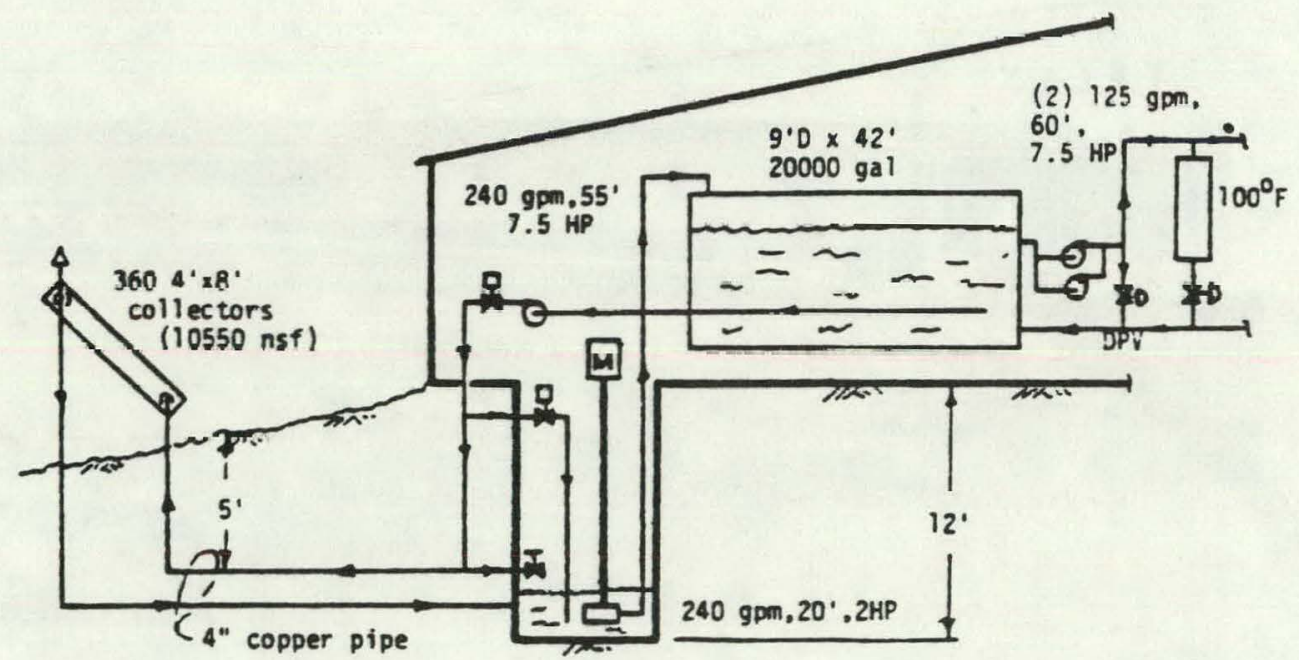

Figure 2. Telex Communications Solar Energy System Flow Schematic 


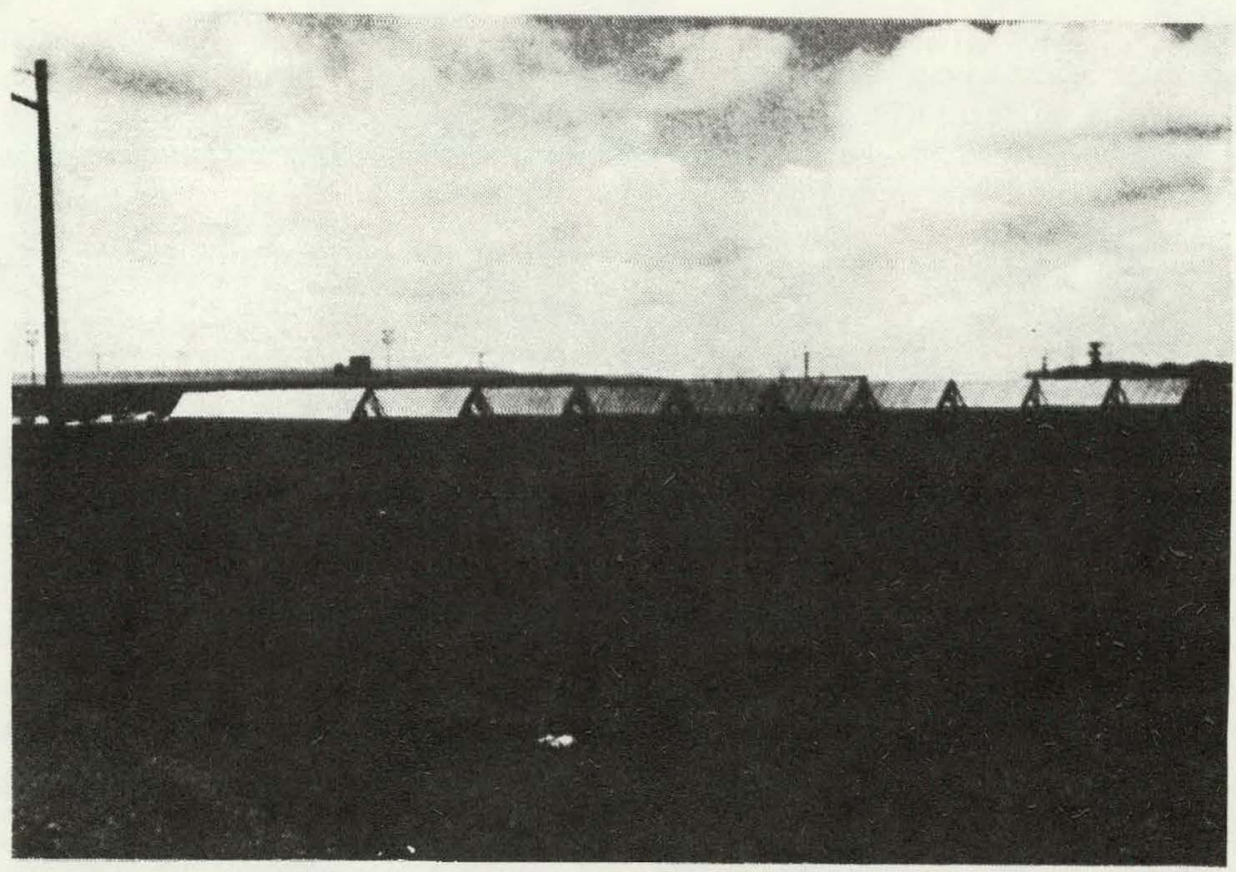

Figure 3. Collector Field

\subsubsection{Collection}

The solar collectors used on the project are the Mark III model manufactured by InterTechnology/Solar Corporation, Warrenton, Virginla. A total of 360 collectors are used, 10 rows of 36 collectors each. The collectors have nominal four-foot by eight-foot dimensions, giving a gross collector area of 11,520 square feet. The collectors are oriented due south and are tilted at an angle of 58.5 degrees from the horizontal.

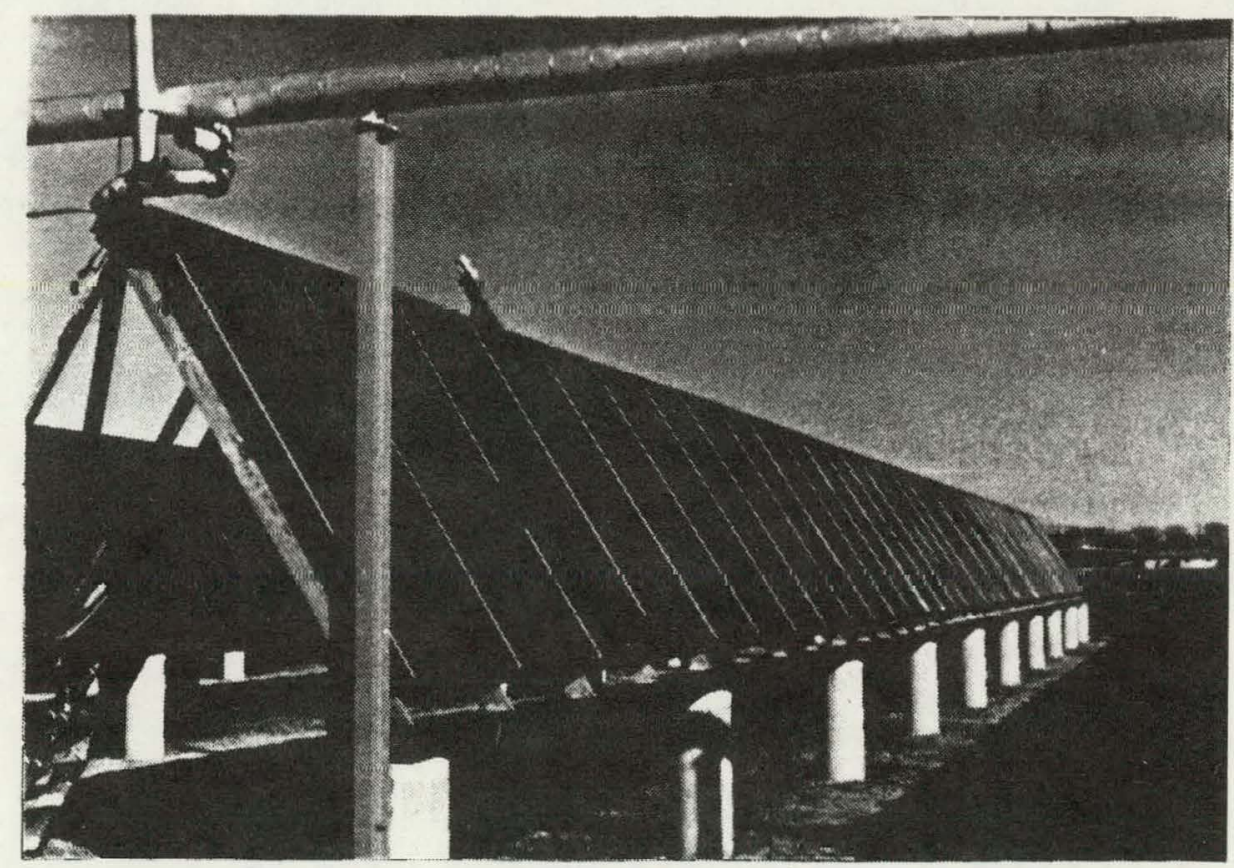

Figure 4. Collector Row 5, with Pyranometer 
The collector specifications are given below. A black chrome selective absorber coating and water-white glass are used. The black chrome selective coating is electroplated on a nickel-coated aluminum extension. The solar absorptivity and thermal emissivity of the black chrome coating are nominally 0.95 and 0.12 , respectively.

Specification 770501

Solar Collector - Medium Temperature

Model Mark III

1. Glazing: Glass, 3/16-inch thick, water-white, singleglazed; transmissivity $=0.91$.

2. Glazing Seal: Continuous molded EPDM rubber.

3. Pressure Plate: 18-gauge stainless steel Type 304.

4. Fasteners: $3 / 4-i n c h \times \# 10$ Truss Head stainless steel sheet metal screws.

5. Frame: 20-gauge galvanized steel, welded corner construction full metal back.

6. Fin Tube Absorber Assembly

a. Manifolds: Two, harddrawn, Type M copper tubes, 2-1/2-inch $\phi$ Nominal.

b. Cross Tubes: Eleven harddrawn, Type M copper tubes, 1/4-inch $\phi$ Nominal.

c. Ahsorber Fins: Eleven Aluminum Extrusions:

$0.060-i n c h \times 4.22-i n c h \times 88.125-i n c h$.

d. Absorber Coating: Black chrome $\alpha 0.95 \varepsilon 0.12$.

7. Manifold Connectors: High temperature formed rubber hose with hose clamps.

8. Insulation: Onc-inch fiberglass around edges, thice-incli fiberglass under absorber.

9. Working Pressure: 50-PSIG; maximum 100-PSIG.

10. Area: 32.0 square feet (47-3/8 inches wide $\times 97-3 / 8$ inches long $\times 5-1 / 4$ inches deep overall dimensions).

11. Effective Absorber Area: 29.7 square feet.

12. Mounting Provisions: Consult factory.

13. Dry Weight: 233 pounds.

14. Liquid Volume: 0.318 cubic feet or 19.87 pounds of water. 
The water-white glass is specially made with a very low iron oxide impurity content (which gives ordinary glass a greenish cast). The solar transmittance of the water-white glass is 0.90 to 0.91 . The slightly rippled pattern in the glass is due to the method of manufacture and has no effect upon its transmittance. The pattern does, however, tend to diffuse the light reflected from the surface of the glass and thus produce a less intense glare.

The InterTechnology/Solar Mark III collector was tested according to ASHRAE Standard $93-77$ in 1976 by the University of Connecticut Solar Energy Test Facility. The resulting $F_{R}(\tau \alpha)$ was 0.75 , with an $F_{R}\left(U_{L}\right)$ of -0.86 , based on gross collector area (32 square feet) with a flow rate of 0.33 to $0.40 \mathrm{gpm}$. The Mark V collector, which is the same as the Mark III except that it is smaller (19square-foot gross area), was tested by the Florida Solar Energy Center. The results were:

$$
\begin{aligned}
& F_{R}(\tau \alpha): 0.704 \\
& F_{R}\left(U_{L}\right): 0.764
\end{aligned}
$$

based on gross area with a flow rate of $0.5 \mathrm{gpm}$.

In a test performed for the Solar Energy Research Institute, (Reference 1 ), the results were:

$$
\begin{aligned}
& F_{R}(\tau \alpha): 0.675 \\
& F_{R}\left(U_{L}\right): 0.973
\end{aligned}
$$

based on gross area with a flow rate of $0.5 \mathrm{gpm}$.

The design flow rate was $240 \mathrm{gpm}$ for the array, or $0.667 \mathrm{gpm}$ for a 32-square-foot panel. The measured collector flow rate was about $210 \mathrm{gpm}$.

The collectors in each row are piped in parallel using the internal manifolds at the top and bottom of each collector. The connections are made inside the collector box using a reinforced silicune "hump" hose and hose clamps. (See Figure 5.) The hump hoses are also bonded to the copper manifolds using a silicone adhesive. Thermal expansion or contraction is absorbed by the hose.

The collectors are supported by a wood structure which is mounted upon poured concrete piers (Figure 6). The concrete piers were poured to varying heights to give a slope to the structure for collector draining. The east side of the structure is approximately 18 inches below the west end, thus allowing the collectors to drain back to the inlet. The system will drain anytime the solar system pump stops. As the water leaves the collectors, air is bled into the system through standpipes located at the upper west end of each row (Figure 7). These standpipes are heat-taped to prevent freezing. Pre-insulated four-inch copper pipe is buried five feet below-grade to transfer the water to and from the collector field. 


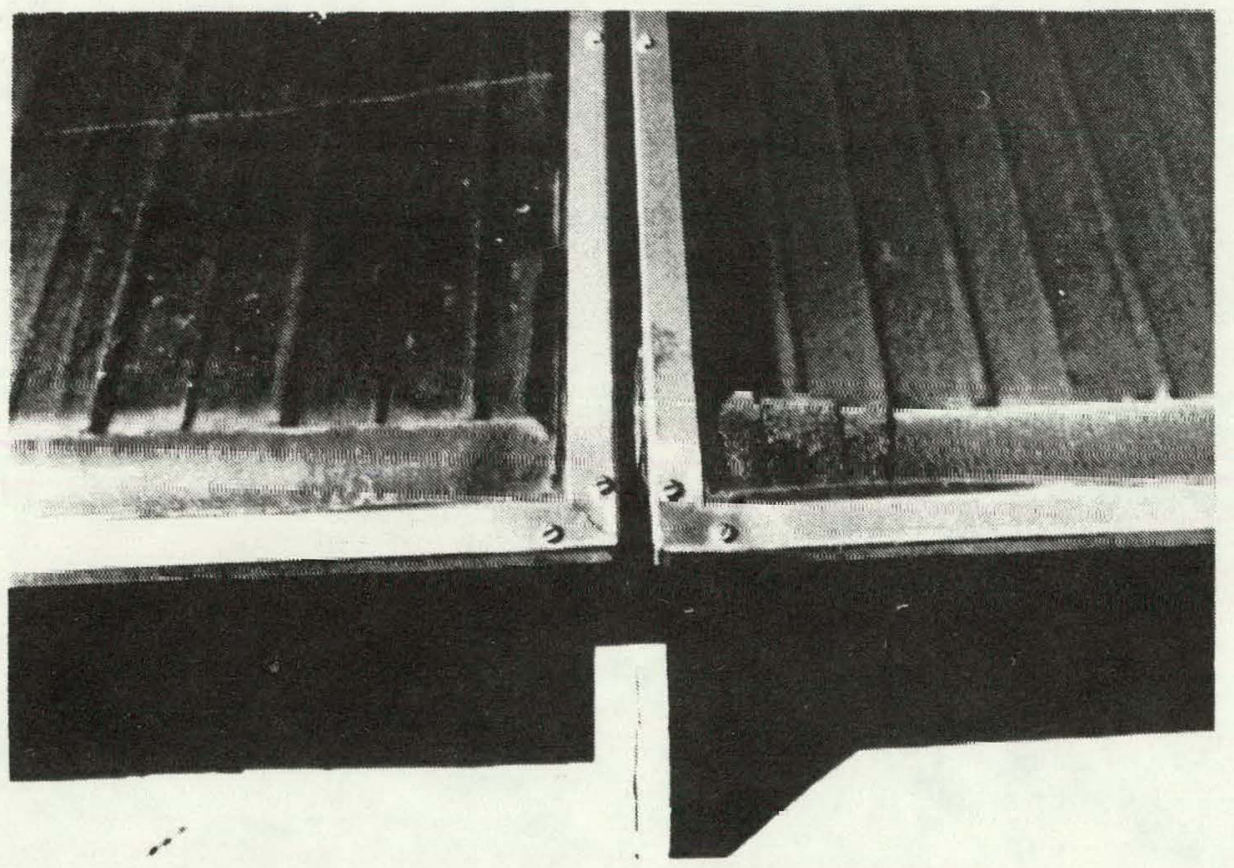

Figure 5. Collector Hose Connection

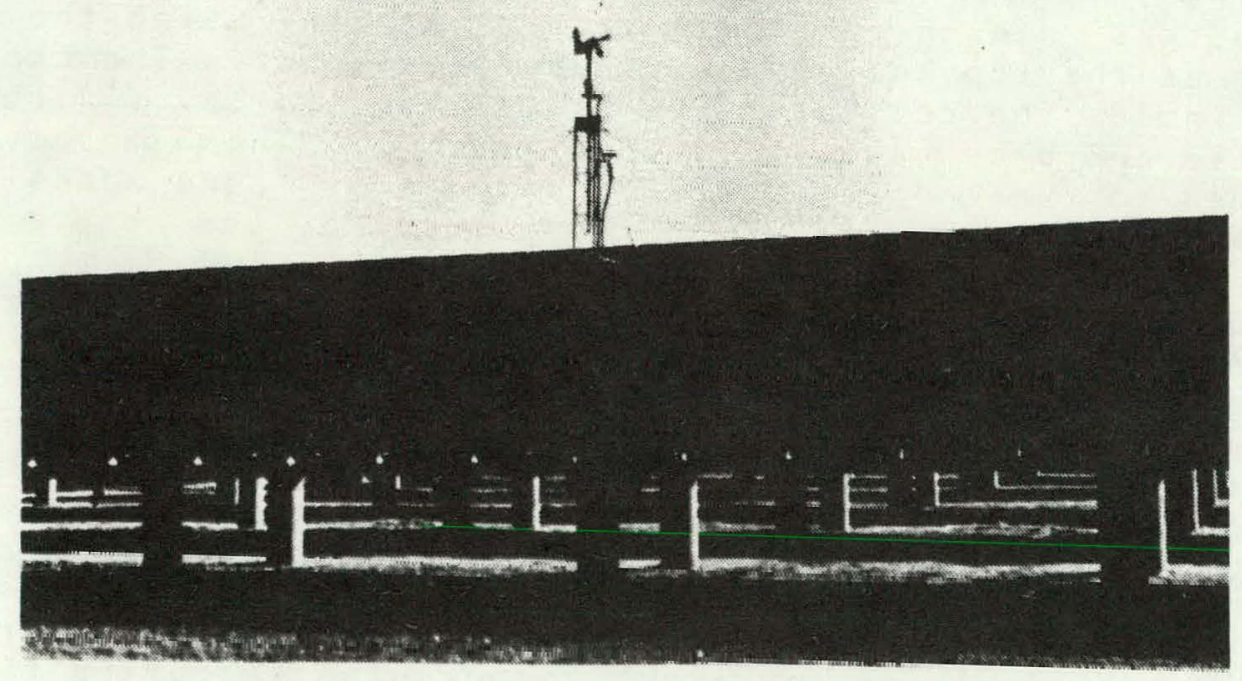

Figure 6. Rear of Row 10, Supporting Truss 


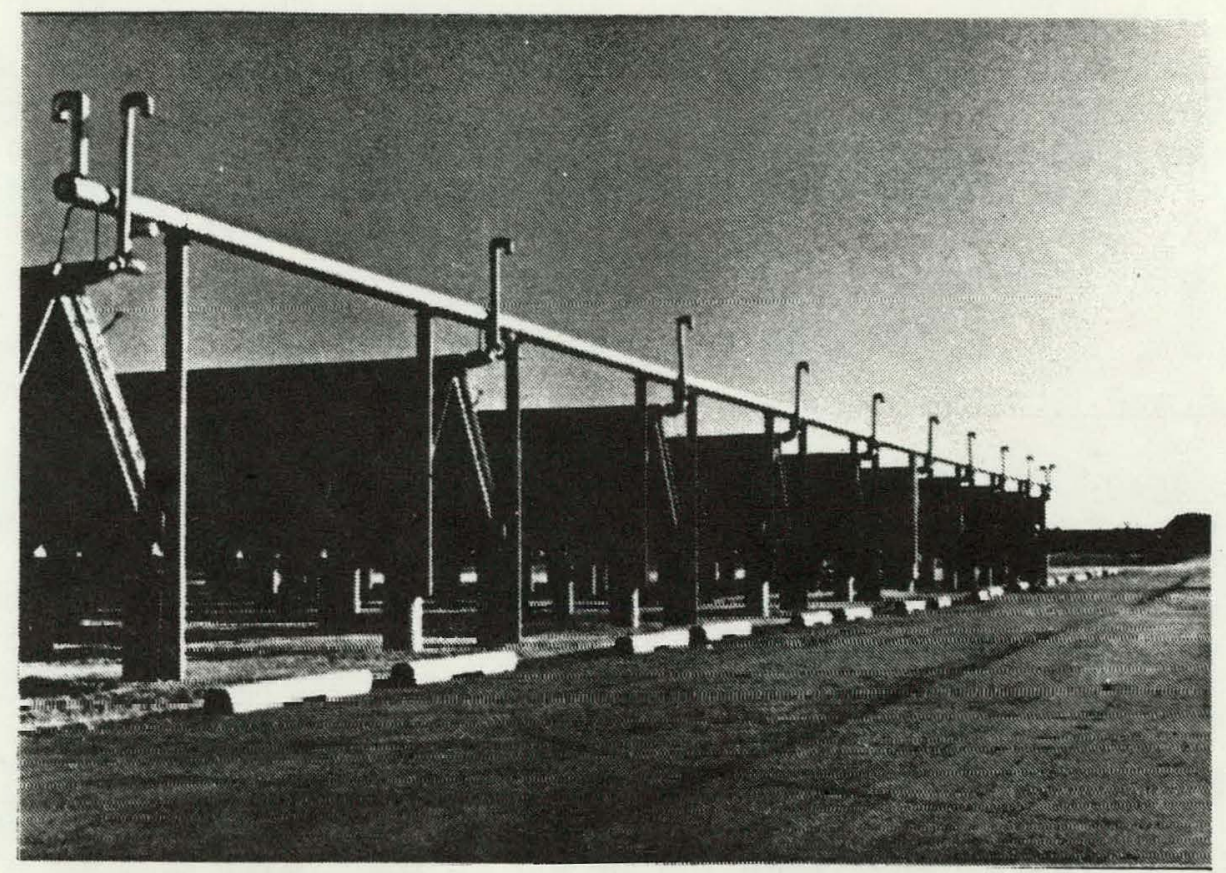

Figure 7. Collector Return Piping and Standpipes

Because the collectors are located below the level of the storage tank, a sump pit is used to hold the return water from the collectors. A sump pump takes the water out of the sump and returns it to the storage tank. An engine-driven sump pump serves as a backup to the primary sump pump if it fails or if there is an electrical power failure. In addition, there is an overflow to carry water from the sump to the outside if the backup fails. The sump is three feet in diameter and 11 feet deep, with a capacity of about 600 gallons. (See Figure 8.) The collectors and associated piping hold $800+$ gallons of water.

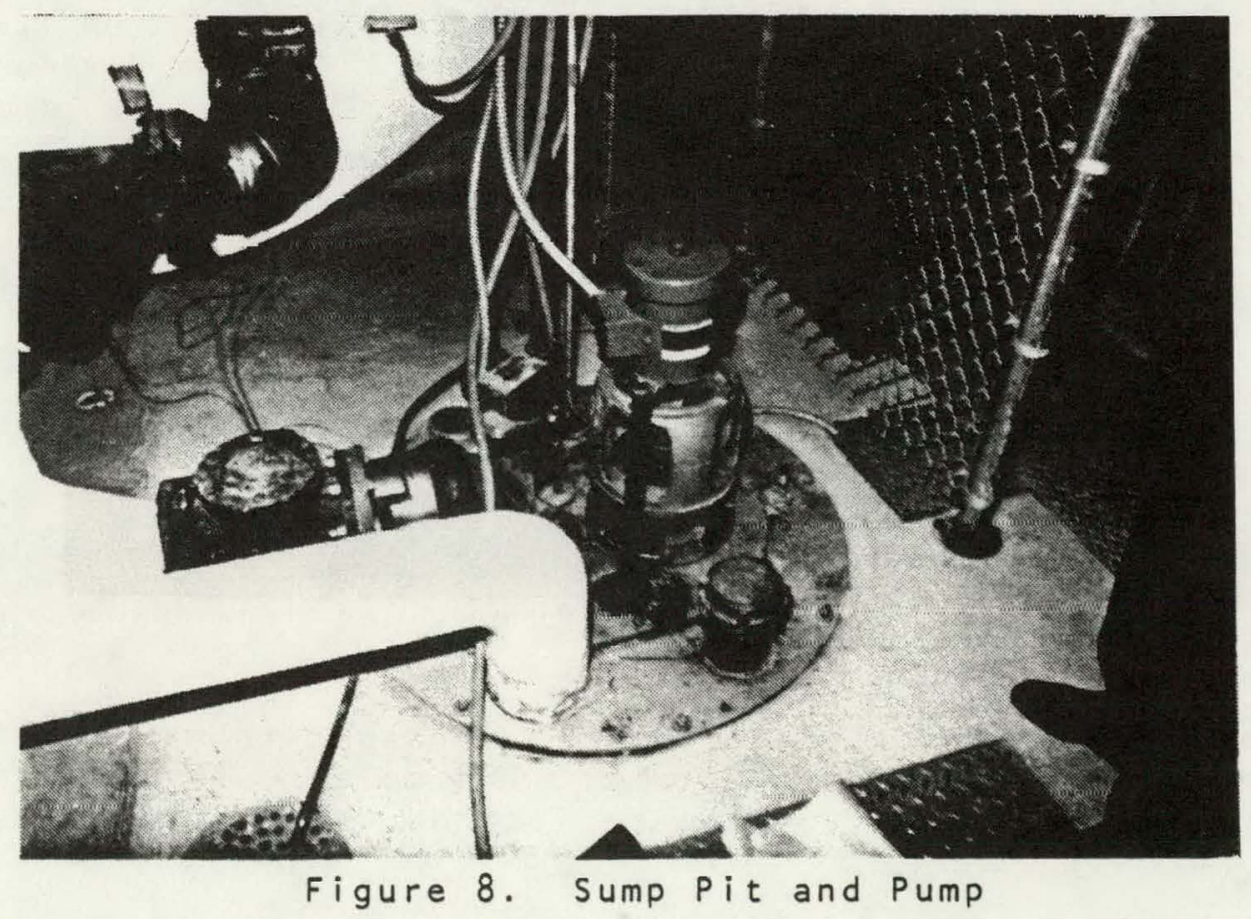


A formal soils report indicates that the water table fluctuates from the surface down to six feet in depth with the last year's variation ranging from three feet to six feet in depth. The soil material is expansive clay, and the frost depth is reported to be at least five feet. There is a paved parking lot (of about

150 feet in width) between the building and the collector field.

\subsubsection{Thermal Storage}

Thermal storage for the solar system is provided by a 20,000-gallon water storage tank located inside the building at the east end. The dimensions of the tank are nine feet in diameter by 42 feet long. The tank was constructed from 5/16-inch-thick hot-rolled sleel. Insulation for the tank is provided by six inches of fiberglass, giving a total $R$ value of 20 .

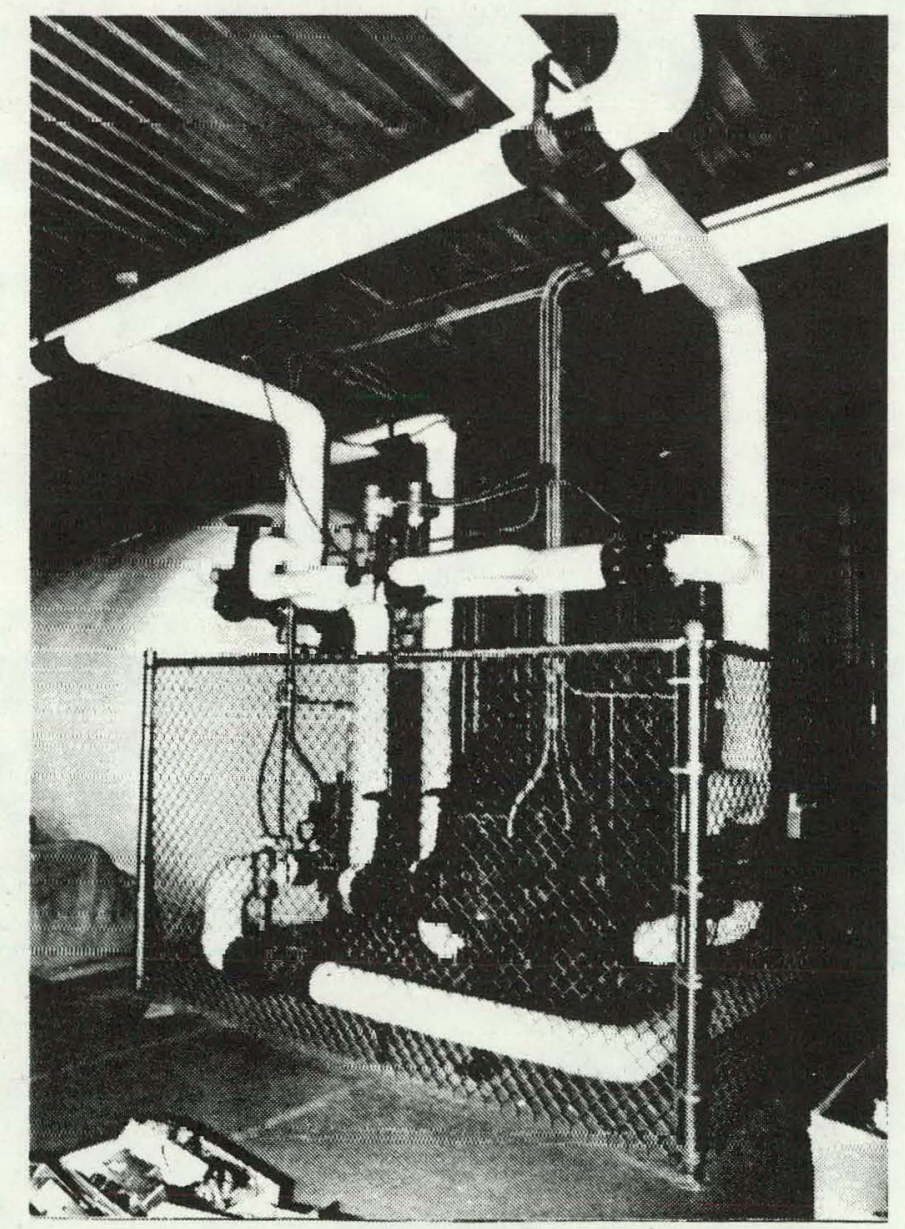

Figure 9. Storage Tank, Pumps, and Piping

Piping to and from the storage tank is arranged to make full use of the storage capacity of the tank. The solar water return and the heating system supply pipes are located very close to each 
other at the top of the south end of the tank. The heating system return water comes back to the tank at the north end. Although the solar pump is physically located at the south end of the tank, it is supplied with water from the bottom of the north end through a four-inch pipe mounted inside the tank. (See Figure 10.)

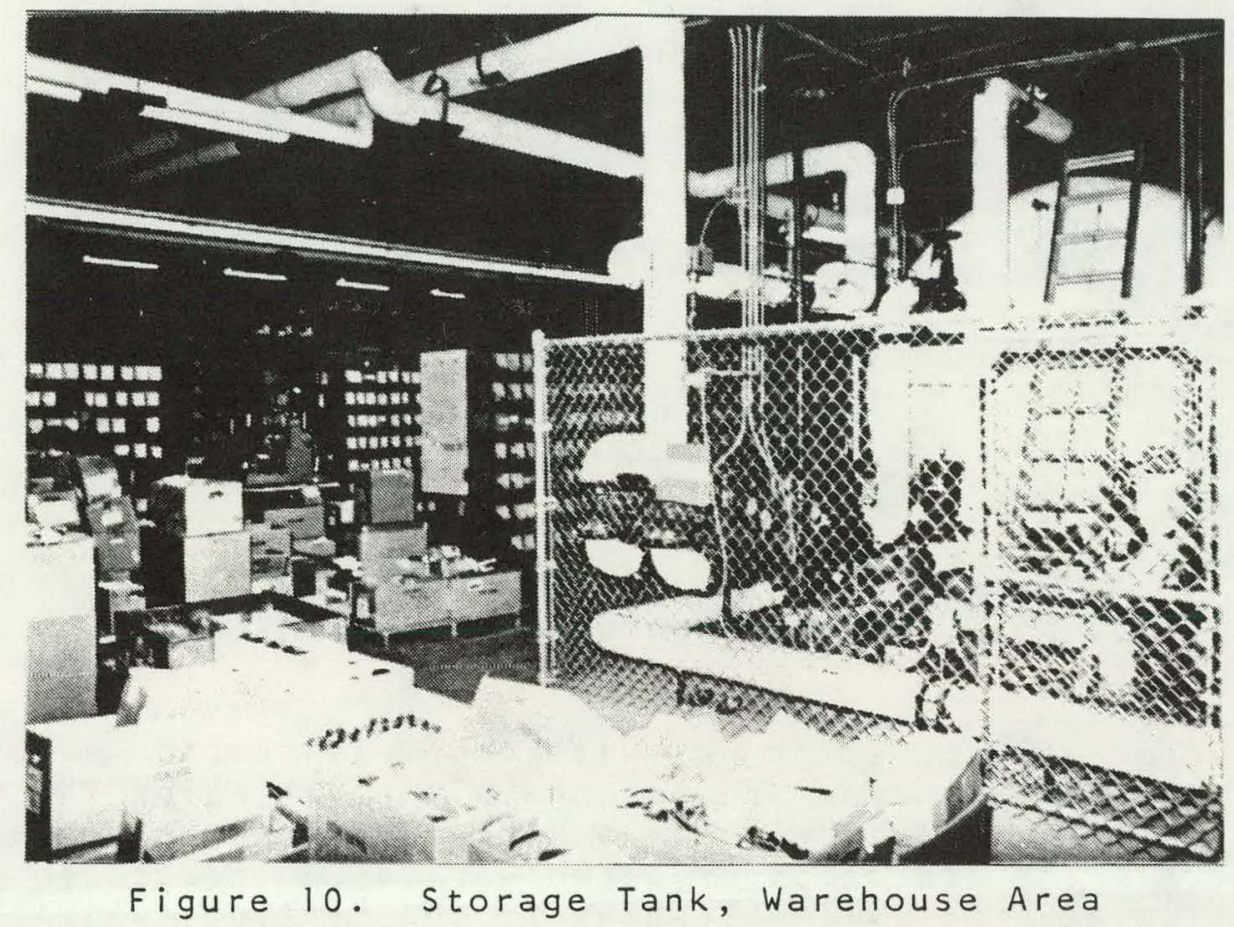

Because the collectors and associated piping hold a significant quantity of water $(800+$ gallons), the water level will vary due to the operation of the solar pump. The water level was measured on February 27,1981 , and at that time the volume of water in the tank (collectors full) was calculated to be 18,040 gallons. Makeup water to the tank is automatically supplied by a low- and highlevel control. The makeup water is treated by a resin-type water softener. Under normal conditions, the amount of makeup water required by the system should not be large (less than l,000 gallons/ year), since the only way water is normally lost is through evaporation.

\subsubsection{Heating}

Heating of the plant is accomplished by water-to-air heating coils located in the nine existing air-handling units, and by three water-to-air unit heaters. The water coils in the air-handling units are located upstream from the existing electric heating elements. This location results in more efficient operation of the solar heating system, since the coldest air reaches the water coils first and can thus be preheated before it reaches the electric elements. In this way, the water in the storage tank can be used down to temperalures of $80^{\circ} \mathrm{F}$ or lower. 


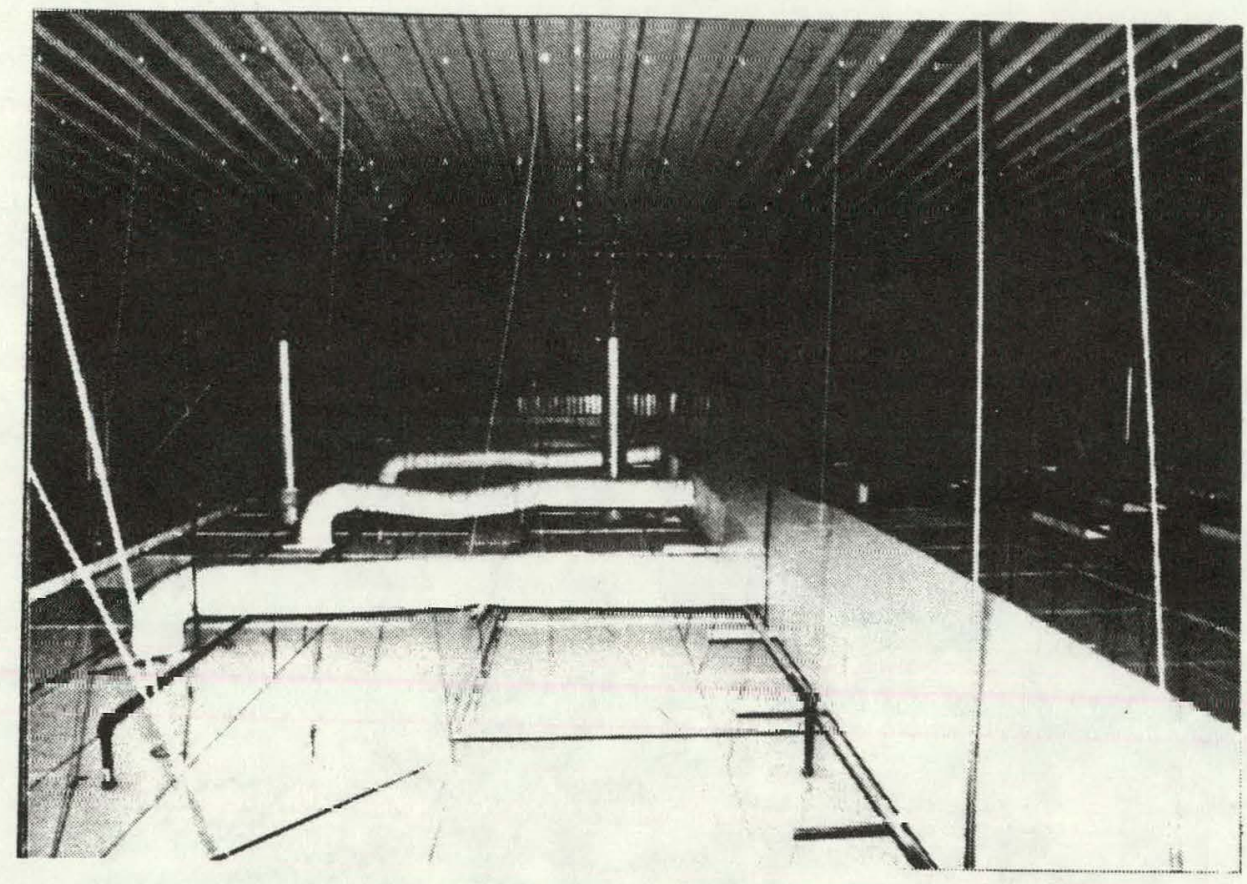

Figure 11. Space Heating Ductwork

The operation of each solar hot water coil is controlled by a thermostat located in the area of the plant served by the airhandling unit in which the coil is located. The thermostat actually controls the operation of a two-way valve located in the solar hot water supply line leading to the heating coil. The thermostat and valve are the proportional type. That is, the opening and closing of the valve are controlled by the thermostat in direct proportion to the deviation of the plant air temperature from that set on the thermostat. This proportional action takes place over a $\pm 2{ }^{\circ} \mathrm{F}$ range. Thus, if the thermostat is set at $66^{\circ} \mathrm{F}$, the heating valve, will be fully clused at $68^{\circ} \mathrm{F}$ and fully open at $64^{\circ} \mathrm{F}$.

If the solar tank temperature is not high enough to provide sufficient heat to meet the requirements of a particular zone, then the temperature of the zulle will continue bo fall. The electric heating thermostats are set $3^{\circ} \mathrm{F}$ to $40^{\circ} \mathrm{F}$ below the solar heating thermostats and will thus turn on the electric heating coils if the tank temperature is too low. Note that, even if the electric heaters turn on, some heat is still being extracted from the solar water coil (since il is upstream from the electric heaters).

Three unit heaters are located in the areas of the plant that are not served by a central air distribution system. These heaters are controlled by standard on-off thermostats. Whenever the space requires heat, the thermostat turns on the unit heater fan. When the heating demand is met, the fan is turned off. 
Hot water from the solar storage tanks is supplied to the heating coils by two hot water supply pumps located at the south end of the tank. These pumps are called $P 2$ and $P 3$ on the solar control panel. During the heating season, pump $P 2$ runs continuously. Pump $P 3$ is used as a backup; the pumps do not run together. Water from the hot water supply pump flows not only through the heating coils but also directly back to the tank through a short bypass line. The amount of water passing through the bypass line is controlled by two regulating valves in the bypass line. These regulating valves are controlled so that a constant pressure is maintained at the outlet of the pumps. If the heating coils demand more water, the pressure will fall and the regulating valves will throttle down the flow in the bypass line to maintain the pressure.

Tables 1 and 2 describe the heating coils and unit heaters at Telex Communications, respectively. Table 3 gives the locations and power ratings for the electric heaters.

Table 1. HEATING COIL SCHEDULE

TELEX COMMUNICATIONS

\begin{tabular}{|c|c|c|c|c|c|c|c|c|}
\hline \multirow[b]{2}{*}{$\begin{array}{l}C 01 L \\
\text { NO. } \\
\end{array}$} & \multirow[b]{2}{*}{ LOCATIOM } & \multirow[b]{2}{*}{ CFH } & \multicolumn{2}{|c|}{ AIR } & \multicolumn{3}{|c|}{ WATER } & \multirow[b]{2}{*}{$\begin{array}{l}\text { CAPACITY } \\
\text { (BTU/HR) } \\
\end{array}$} \\
\hline & & & $\begin{array}{l}\text { EATER ING } \\
\text { TEMPERATURE } \\
\text { (OF) }\end{array}$ & $\begin{array}{c}\text { LEAVING } \\
\text { TEMPERATURE } \\
(O F)\end{array}$ & GPM & $\begin{array}{c}\text { ENTERING } \\
\text { TEMPERATURE } \\
\text { (OF) } \\
\end{array}$ & $\begin{array}{c}\text { TEAVING } \\
\text { TEMPEAATUAE } \\
(\text { OF })\end{array}$ & \\
\hline I & ARUI & 8,000 & so & 80 & 35 & .105 & 90 & 260,400 \\
\hline 2 & AHU2 & 9.200 & so & 80 & to & 105 & 90 & 300,000 \\
\hline 3 & ' ANUS & 9.200 & so & 80 & to & 105 & 90 & 300.000 \\
\hline 4 & AnUS & 3.800 & so & 80 & 16 & 105 & 90 & 124.000 \\
\hline 5 & AnUS & 1.200 & so & 80 & 5 & 105 & 90 & 39.000 \\
\hline 6 & AMU 6 & 1,200 & 50 & 80 & 5 & 105 & 90 & 39.000 \\
\hline 1 & AHU? & 2.000 & 50 & 80 & 9 & 105 & 90 & 65.100. \\
\hline 8 & AHUIA & 10.500 & 50 & 70 & 30 & 105 & 90 & 228.000 \\
\hline 9 & AnU2A & 10,500 & 50 & 70 & 30 & 105 & 90 & 228,000 \\
\hline
\end{tabular}

Table 2. UNIT HEATER SCHEDULE

TELEX COMMUNI ICATIONS

\begin{tabular}{|c|c|c|c|c|c|c|c|c|c|c|c|c|}
\hline $\begin{array}{l}\text { UNIT } \\
\text { No. }\end{array}$ & SERVICE & $\begin{array}{l}\text { CAPACITY } \\
\text { (BTU/HA) }\end{array}$ & CFM & GPN & $\begin{array}{c}\text { ENTERING } \\
\text { TENPERATURE } \\
\text { (OF) }\end{array}$ & $\begin{array}{c}\text { LEAVING } \\
\text { TEMPERATURE } \\
\text { (OF) }\end{array}$ & \multicolumn{2}{|c|}{ MOTOR } & \multicolumn{3}{|c|}{ ELECTRICAL } & $\begin{array}{l}\text { MODEL } \\
\text { NO. }\end{array}$ \\
\hline 1 & storege & 78.000 & 5.430 & 12 & 105 & 90 & 0.5 & 1.140 & 120 & 60 & 1 & $Y U-2620$ \\
\hline 2 & stortege & 78.000 & 5.430 & 12 & 105 & 90 & 0.5 & 1,140 & 120 & 60 & 1 & $Y U=2620$ \\
\hline $\mathbf{3}$ & storege & 78,000 & 5.430 & 12 & 105 & 90 & 0.5 & 1.140 & 120 & 60 & 1 & $Y U-2620$ \\
\hline
\end{tabular}




\section{Table 3. ELECTRIC HEATERS}

TELEX COMMUNICATIONS

\section{LOCATION}

Subassembly

Lunchroom

East Office

West office

Lobby

Center office

ResliuUuII

Amp Wast

Amp North

TMS Line East

TMS Line West

300 Line

QC Receiving

West Building Restrooms

Shipping Dock

Rccciving Dock

East Warehouse

West Building

North Warehouse

North Warehouse

Restrooms
POWER RATING

(kw)

22.5

30.0

12.5

15.0

5.0

10.0

3.0

34.0

34.0

22.0

54.0

17.6

30.0

4.0

20.0

20.0

30.0

18.0

50.0

20.0

13.0

The total power rating of all the electric heaters at Telex Communications is $720.6 \mathrm{kw}$.

\section{2 .4 cunituls}

The control subsystem governs the operation of the solar system pumps and control valves. The design and installation of the control subsystem was performed by Johnson Controls of Minneapolis according to the specifications of the solar system engineer, InterTechnology-/Solar Corporation.

The control panel is located on the east wall of the building adjacent to the solar storage tank. The controls for the solar system pumps, the sump pump, the heating distribution pumps, 
and motorized valves are located in this panel. A number of temperature gauges are also provided on the face of the panel to allow the performance of the systems to be monitorized.

The collector control settings are given in the next section, Operational Modes.

The heating control settings are discussed in section 2.2.3, Heating.

\subsection{OPERATI ONAL MODES}

The system has two modes of solar operation.

Mode 1 - Collector-to-Storage - This mode is entered when the temperature of the collector surface exceeds the water temperature in the water thermal storage by $25^{\circ} \mathrm{F}$. Water is circulated from storage through the collectors until the storage temperature reaches $190^{\circ} \mathrm{F}$, or until the difference between the collector plate temperature and storage temperature is less than $2^{\circ} \mathrm{F}$.

Mode 2 - Storage-to-Space Heating - This mode is controlled by manually preset thermostats. The minimum designed operational temperature in water thermal storage is $100^{\circ} \mathrm{F}$, although the control system does not inhibit operation below this temperature. Water is circulated through the heat exchangers and returned to storage until the demand is satisfied. The heating pump normally runs continuously throughout the heating season.

\subsection{PIPES}

The long underground run of four-inch pipe between the collector field and the storage tank is Rovanco Insul-8, with 0-ring coupled copper Type L pipe pre-insulated in the factory with one inch of polyurethane foam, and jacketed with seamless polyvinylchloride $(P \vee C)$.

\subsection{PUMPS}

The collector pump is a Bell and Gossett Series 80 , size $3 \times 3 \times 9 \frac{1}{2}$, centrifugal pump. The collector pump is a seven and one-half horsepower pump, rated at 200 gallons per minute with a head of 80 feet. it is a bronze fitted pump and runs at $1,750 \mathrm{rpm}$.

The sump pump is an Aurora Model 531 , size $4 \times 4 \times 7 \mathrm{~A}$. Tlite sump pump is a two-horsepower pump, rated at 240 gallons per minute with a 20-foot head.

The load pumps are Bell and Gossett Series 80 , size $2 \frac{1}{2} \times 2 \frac{1}{2} \times 9 \frac{1}{2}$, centrifugal pumps. These pumps are identical, five-horsepower pumps, raled at 125 gallons per minute with a head of 60 feet. They are bronze fitted, and run at $1,750 \mathrm{rpm}$. 


\section{THIS PAGE}

\section{WAS INTENTIONALLY \\ LEFT BLANK}




\section{SECTION 3}

\section{SYSTEM PRELIMINARY DESIGN}

\section{I REQUIREMENTS}

The Telex Communications office and manufacturing plant in Blue Earth, Minnesota was originally all electrically heated. Because of rising electricity costs following the energy shortage which began in october 1973, Telex Communications looked for an alternative fuel source for space heating. Telex Communications was awarded a contract from the Energy Research and Development Administration (ERDA) to construct a solar space heating system. The solar system was required to supply approximately $75 \%$ of the annual space heating load (about 2,600 million BTU) (the domestic hot water load is very small), and to have a 20 -year life.

\subsection{DESCRIPTION}

The retrofit solar energy system was one of those built under the Program Opportunity Notice (PON) program of ERDA. In November 1975, the InterTechnology Corporation (ITC) (now defunct) of Warrenton, Virginia, submitted a proposal to ERDA to design a solar space heating system for Telex Communications.

The original proposal included 20,000 square feet of flat-plate collectors, ground-mounted adjacent to the building, and a 40,000gallon storage tank buried below the frost line beneath the collectors. The collector fluid was water, with freeze protection derived by automatically draining the collector fluid back to the storage tank when the collector pump stopped. The heated water was to be circulated to heat exchangers at each electric heater location.

Two types of collectors were contemplated, one made by solar Corporation of America (later merged with ITC to form ITC/Solar) with a selective absorber surface and the PPG collector with a flat-black painted absorber.

\section{3 PERFORMANCE ESTIMATES}

The performance of the proposed solar system was estimated using an hourly simulation model developed by ITC. The computer program for the simulation of flat-plate solar energy collector performance was based upon detailed heat balance equations for the absorber plate and the cover plates. The analyses were done individually over each month for the geographical location of the solar collector. The weather data required were $\bar{H}$, average daily total radiation (beam + diffuse) on a horizontal surface for the month; to, the average daytime ambient temperature, and $\bar{K}_{T}$, the fraction of extraterrestrial solar radiation that reaches the 
local ground level. Variation of instantaneous solar flux on a horizontal surface over the day, from sunrise to sunset was assumed to be a cosine function such that the flux was zero at sunrise and sunset and maximum at solar noon. The area representing the cumulative energy was $\bar{H}$. The instantaneous value of total solar flux was divided into its beam $(\bar{B})$ and diffuse ( $\bar{D})$ components on the basis of $\bar{K}_{T}$. The beam component $\bar{B}$ was multiplied by a factor (determined by solar declination, tilt angle, and azimuth of solar collector, and solar time), and combined with $\bar{D}$ to get a total instantaneous solar flux on the tilted surface of the collector. The dependence of absorptance-transmittance product on the angle of incidence was taken into account. From the total instantaneous flux, the heat collected per hour was calculated every half hour using detailed heat balance equations for the absorber plate and the cover plates. The storage tank temperature was adjusted according to the solar heat collected and the heating load on the system.

The insolation was varied randomly over the month such that the average was the same as the input value $\bar{H}$.

According to the proposal, the double-glazed selective surface collector used in the performance calculation had an emissivity of 0.4 , which is very high for a selective surface, and a reasonable absorptance-transmittance product of $U .15$. The resules of the calculation are summarized in Table 4.

Table 4. TELEX COMMUNICATIONS PERFORMANCE CALCULATIONS

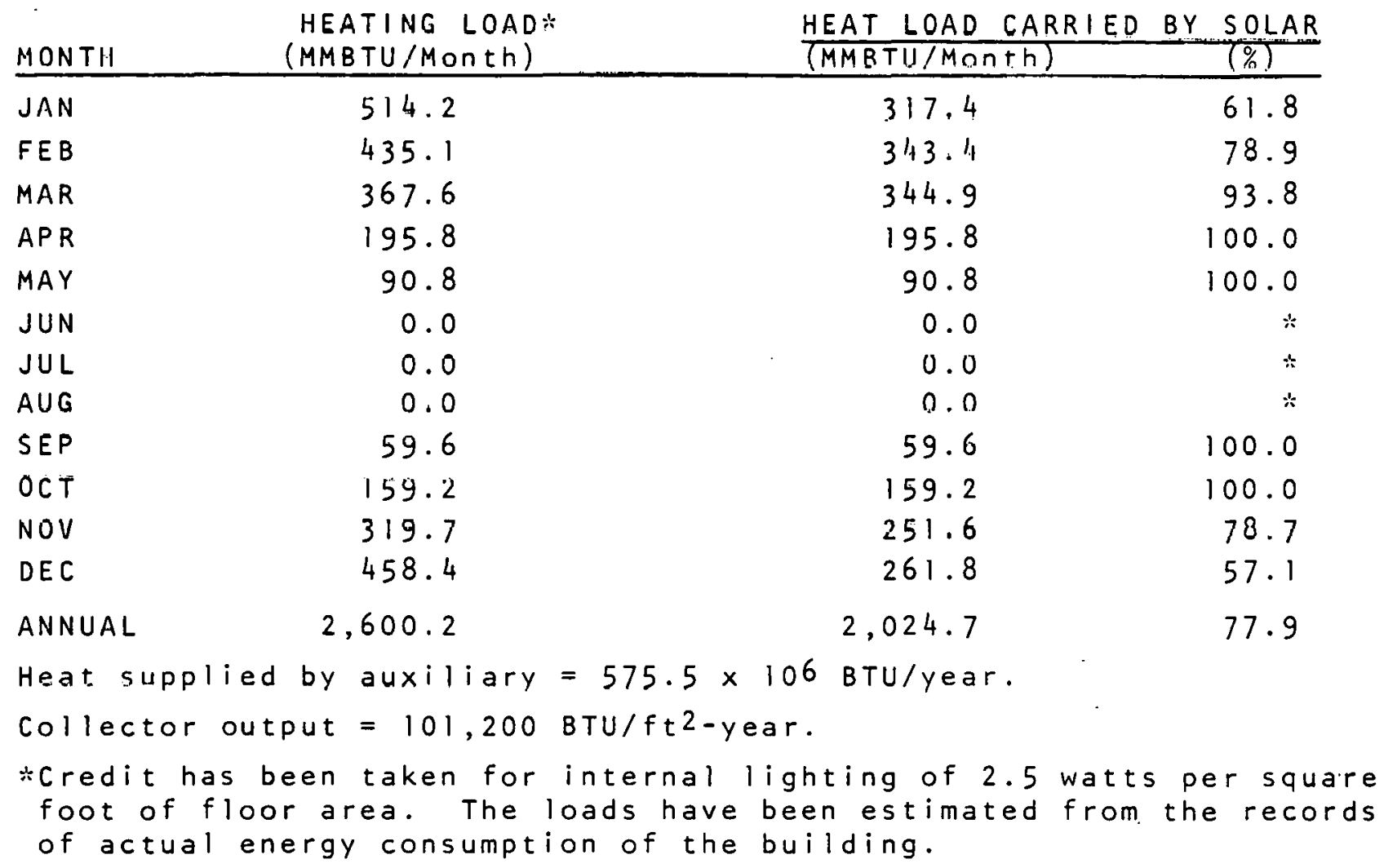


The parameters used in the calculations were:

$$
\begin{array}{ll}
\text { Collector tilt angle } & 55 \text { degrees } \\
\text { Collector area } & 20,000 \mathrm{ft}^{2} \\
\text { Storage size } & 40,000 \text { gallons }
\end{array}
$$

At an energy cost of $3.7 \mathrm{k} / \mathrm{kwh}$, the projected solar system savings were $\$ 21,955 /$ year.

\subsection{OPERATING MODE ANALYSIS}

The proposed operation of the system was as follows:

Collector-Storage Loop - Whenever the collector plate temperature rises above the storage tank temperature, the comparator $(c-1)$ energizes a timer. This sequence will be called the "startup cycle." The timer then shall operate for a period of $f i v e$ minutes irrespective of $\mathrm{c}-1$ with its contactor closed, thereby energizing the collector pump for a minimum of five minutes. At the end of the five-minute run, the timer shall keep the pump energized unless $c-1$ indicates that the tank temperature is warmer than the plate temperature. This sequence will be called the "shutdown cycle." At that time, the timer shall reverse its operation and, at the end of another five minutes (assuming $c-l$ does not call for collection), the timer shall deactivate the collector pump. If c-l should call for collection during the "shutdown cycle," the timer shall then begin to operate on the previous or "startup cycle" with the excep$t i$ on of rigid adherence to the five-minute delay.

Whenever the pump is operating, the two dump valves shall close. Whenever the pump is de-energized, the valves shall open, draining the collector to the tank.

Space Heating Loop - The performance model assumed that the minimum tank temperature for space heating was $110^{\circ} \mathrm{F}$, and the maximum allowable tank temperature was $2200^{\circ}$. It was assumed that, with $1100 \mathrm{~F}$ or hotter tank water, solar energy could carry the heating load. If the tank temperature was less than $110^{\circ} \mathrm{F}$, elcctrical energy would heat the building. Solar and auxiliary energy would not be used together.

\subsection{COST ESTIMATES}

The capital cost of the solar system was estimated at $\$ 360,482$.

The breakdown was:

solar cullectors

Storage Tank and Insulation

Structural

Pumps

Piping

Controls

ITC Design Fee

$\$ 210,000$

76,000

TOTAL

25,000

2,300

16,250

2,500

28,432

$\$ 360,482$ 
3.6 RELIABILITY

The estimated design lives of the subsystems were:

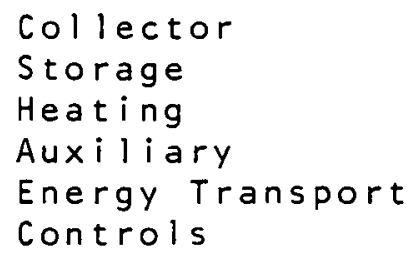




\author{
SECTION 4 \\ SUBSYSTEM PRELIMINARY DESIGN
}

In June 1976, Telex Communications was awarded a contract from the Energy Research and Development Administration (ERDA) to build a solar space heating system. InterTechnology/Solar Corporation began the design in August 1976.

\title{
4. 1 COLLE.CTOR
}

The collector array area in the proposal had been 20,000 square feet. In the first full-fledged preliminary system design, this area was reduced to 14,880 square feet. The design called for 13 rows of collectors, with 36 collectors in 12 . of the rows, and 33 collectors in the 13 th row, a total of 465 four-foot by eightfoot collectors. The collectors chosen at this stage were the (single-glazed, black chrome) ITC/Solar Mark III collectors that were actually installed in the system. They are fully described in the collection subsystem description, section 2.2.1. Each row of collectors is supported by 20 concrete piers in two rows of ten. The rows are spaced eight feet, two and one-half inches apart, with the piers 16 feet apart in the row. The piers are 16 inches in diameter, drilled and cast in place to a depth of six feet beneath the surface. The height of the piers varies to produce a slope in the piping. The west end of the array is one foot higher than the east end. The minimum height from ground-level to the bottom of the collectors is about four feet. The frost depth at the site is reported to be at least five feet. Seasonal movements up and down of the structure due to frost heaving could be tolerated provided there was not any excessive differential movement. A soils engineer, Donovan K. Stormore, P.E., of Soil Exploration Company of St. Paul, Minnesota, was asked to consult on the structural design. He recommended the drilled and cast-in-place pier, with a tip elevation below the frost line. He stated that "since the subsurface profile at the site is relatively uniform, large differential movements would not be expected, assuming similar ground-cover conditions over the site."

The collectors are supported by an inclined vertical truss framing system, constructed of treated wood. The design wind load was 20 PSF, corresponding to a wind speed of $90 \mathrm{miles}$ per hour. The wind loading was considered adequate to support snow loads, because the collectors are four feet of the ground and steeply sloped ( 58.5 degrees). Snow should not stand on the collectors.

\subsection{STORAGE}

The storage tank designed for the 14,880-square-foot collector array was a buried steel tank with a capacity of 30,000 gallons. The tank was to be 10 feet six inches in diamctcr and 46 feet long. 
It was to be buried at the north end of the collector array, with the top of the tank four feet below-grade. A masonry pit with a 12-inch wall at one end of the tank would contain the collector pump and the two load pumps. Six inches of urethane insulation and a protective coating were specified. All the piping connections (two collectors, two loads, and makeup water) were in one end of the tank, in the masonry pit. There was an internal pipe 38-1/2-feet long running lengthwise about nine inches above the bottom of the tank for the collector supply water. The collector return water came into the pit end of the tank about two-thirds the distance from the bottom. This arrangement should ensure thorough mixing of the collector water with the storage water.

The heating supply water pipe came out of the tank very close to the collector return pipe, allowing a desirable short circuit. The heating return pipe was connected to the tank about one-third the tank diameter from the bottom. The tank was vented to the atmosphere with automatic water makeup. The tank saddles were to be bolted to a concrete pad, using 70 three-quarter-inch anchor bolts with seven-inch embedment.

\subsection{HEATING}

The solar space heating distribution system design included nine heating coils, located in existing air-handler units upstream of the electric heaters, and three solar unit heaters. Two identical pumps were used in parallel to supply the hot water to the heating coils. Each heating coil had a two-way valve that would partially close during periods of reduced heating demand. This closing would cause a valve that was regulated by the pressure differenlial te tween the supply and return lines to open. This pressure differelltial valve was located in a line bypassing the heating coils as heating demand was reduced. A flow switch in lhe bypass line would sliut off one pump whon the flow in the hypass loop was one-half of the total flow. At this point, the pressure differential valve closed, allowing the total flow from one pump to pass through the heating coils. As the heating demand was further reduced, the pressure differential valve would open lu bypass somc of the flow around the heating coils. If the heating demand increased, the pressure differential valve would close to divert more flow to the heating coils. If the fluw in the bypass line fell too low, a second flow switch would activate the other pump.

From the heat exchanger characteristics, it was determined that $70 \%$ to $80 \%$ of the design heating capacity would be retained If the water flow to the coil were halved. It was concluded that only one pump would be running for the large majority of the total operating hours. The two-pump design also allowed the system to remain in operation if nne pump failed. 


\subsection{PIPING}

The piping size and layout are shown in considerable detail in the drawings in Figures $\mathrm{C}-6, \mathrm{C}-7$, and $\mathrm{C}-8$ in Appendix $\mathrm{C}$. The underground pipe was to be polytherm, a steel pipe system factory-insulated with one-inch of polyurethane foam, coated with a fiberglass reinforced polyester resin.

\subsection{PUMPS}

Four pumps were required, a collector pump, two load pumps, and a small sump pump to evacuate water from the masonry pit when necessary. Their characteristics are outlined in Table 5.

\section{Table 5. PUMP SCHEDULE FOR TELEX COMMUNICATIONS}

\begin{tabular}{|c|c|c|c|c|c|c|c|}
\hline $\begin{array}{l}\text { PUMP } \\
\text { NO. }\end{array}$ & SERV I CE & GPM & HEAD & RPM & $\begin{array}{l}\text { MOTO } \\
\text { HP }\end{array}$ & TYPE & REMARKS \\
\hline 1 & Solar collectors & 300 & 80 & 3,500 & 15 & $\begin{array}{l}\text { Centrifugal } \\
\text { in line }\end{array}$ & $\begin{array}{l}\text { Similar to BEG } \\
\text { Series } 80\end{array}$ \\
\hline 2 & Heating Coils & 125 & 110 & 3.500 & 15 & $\begin{array}{c}\text { Cencrirugal } \\
\text { in line }\end{array}$ & $\begin{array}{l}\text { Similar to } B \varepsilon G \\
\text { Series } 80\end{array}$ \\
\hline 3 & Heating Coils & 180 & 110 & 3,500 & 15 & $\begin{array}{c}\text { Centrifugal } \\
\text { in line }\end{array}$ & $\begin{array}{l}\text { similar to } B \varepsilon G \\
\text { Series } 80\end{array}$ \\
\hline 4 & Sump Pit & 5 & 15 & 1.725 & 0.5 & Sump Pump & $\begin{array}{l}\text { Similar iu Aurora } \\
\text { Series } 510\end{array}$ \\
\hline
\end{tabular}

\subsection{CONTROLS}

Tank-collector Operation - Whenever the collector plate temperature would rise $5^{\circ} \mathrm{F}$ above the storage tank temperature, a comparator, c-l, would energize the collector pump. Once the pump starts, it would stay energized for at least 10 minutes. At the end of $10 \mathrm{~min}-$ utes, the pump would shut down if the collector temperatures were within $2{ }^{\circ} \mathrm{F}$ above the tank temperature, otherwise the pump would stay energized. Valve $V-l$ is a normally open solenoid valve that closes whenever the collector pump is energized. 
THIS PAGE

\section{WAS INTENTIONALLY LEFT BLANK}




\section{SECTION 5}

ECONOMIC ANALYSIS

The cost breakdown for the Telex Communications solar system as of January 14,1977 was as follows:

1. Collectors - 14,880 ft2-F.0.B. Blue Earth $\$ 183,551$

2. System Design (ITC) 28,675

3. Mechanical E Electrical Work a. Cement work including pump house and

b. Collector support

37,190

c. Tank and insulation

24,095

d. Outside mechanical

111,695

e. Inside mechanical

66,400

f. Electrical

9,150

4. Miscellaneous (performance bond, building permit, rust inhibitor, etc.)

15,000

TOTAL

$\$ 557,031$

The contract price was $\$ 459,441$, to be paid for by the government $(\$ 350,000)$ and Telex Communications $(\$ 109,441)$. In order to get the cost down to the contract price, a number of modifications were made to the solar system. The storage tank and pumps were moved into the building, saving approximately $\$ 50,000$. The number of collectors was reduced from 465 to 396 (1) rows of 36 , gross area 12,686 square feet). (The collector array was later reduced again; it was built with 10 rows of collectors, with an area of 11,520 square feet.) The storage tank volume was reduced from 30,000 galions to 20,000 gallons. The collector pump size was reduced from 15-hp to 7.5-hp, but a two-hp pump had to be added. The estimated solar fraction dropped from $80 \%$ to $70 \%$. 
THIS PAGE

WAS INTENTIONALLY

$\therefore$ LEFT BLANK 


\title{
SECTION 6
}

\author{
DESIGN REVIEWS AND REVISIONS
}

\section{I NATIONAL AERONAUTICS AND SPACE ADMINISTRATION DESIGN REVIEW}

The National Aeronautics and Space Administration (NASA) reviewed the Telex Communications design in December 1976. The review included civil, structural, architectural, mechanical, and electrical comments. The complete Design Review Comments are included here in Appendix F-l. ITC's structural consultant, Norman C. Pardue, Jr., P.E., "much dismayed and incensed at the quality of the review," wrote a long, detailed rebuttal to the comments, which is also included in Appendix F-2. ITC's comments on the review are included in Appendix F-3. Many of the comments simply asked for more detail or clarification in the specifications. No changes in the design were made as a result of the review.

In order to bring the system cost within the budget, the system was redesigned with an above-grade storage tank near the collector array. This design required considerable complexity to prevent freezing in the case of a power failure. The design finally used, with an indoor storage tank, was the third design.

\subsection{FINAL DESIGN REVIEW}

A final design review was conducted at Blue Earth, Minnesota on May 4, 1977 with representatives from Telex Communications, Marshall Space Flight Center, InterTechnology, ASHRAE, IBM, the American Institute of Architects ( $A \mid A$ ), and Mankato Plumbing and Heating Company in attendance.

The sump was the principal bone of contention at the final design review. When ITC changed the design location of the storage tank from underground to inside the building, the storage tank became higher than the collector field. Because the design depended on drainback for freeze protection, a sump was added to drain the collectors and a sump pump was added to transfer the water from the sump to the storage tank. The sump had a capacity of about 250 gallons. The collectors and associated piping hold about 800 gallons, so a sewer drain one foot below the top of the sump was provided to handle the overflow in case of a power failure. The consensus of those present at the design review (except ITC) was that this design was totally unsuitable. According to the ASHRAE representative, Douglas M. Jardine, P.E., the result would be "constant flooding of the Telex plant, freezing of collectors in the severe climate of southern Minnesota," saying "one year life expectancy may be overly optimistic." 
Mr. Jardine and Marshall Space Flight Center (MSFC) made the following recommendations to Telex Communications concerning the sump pit:

1. Enlarge the sump pit capacity from 250 to 860 gallons.

2. Add a three-way valve in the sump pit to bypass the sump in a normal operating mode. The sump pit would be used only for draindown.

ITC did not agree with these recommendations, but the as-built system has a three-foot-diameter sump pit holding about 600 gallons, and there is a gasoline-powered sump pump to empty the sump during power failure.

MSFC and Douglas Jardine were also concerned with the operation of the space heating loop. The design had no low temperature shut-off control on the storage tank for shutting off the space heating pumps when the storage temperature drops below usable loads. The fear was that the storage system could turn into a heat exchanger between the $70^{\circ} \mathrm{F}$ plant and the $55^{\circ} \mathrm{F}$ storage areas when $\tau$ he storage tank temperature was low.

ITC felt there was no need for such a control and stated they would not add one. They were as good as their word; no such control was ever added, nor was it needed.

The reviewers were also concerned that there was no freeze protection for the solar coils in the air-handling units. The owner said the fresh air dampers had failed in the past. Apparently, ITC said freeze protection was not needed, while Mankato thought their bid covered such devices. The system was built with freeze prtoection provided by a low-limit thermostat located just after the hot water coil. If the air temperature falls below $40^{\circ} \mathrm{F}$, the fan is turned off, and water flow through the coil is maintained.

Some of the reviewers felt that stratification in the storage tank would cause a decreased solar utilization. ITC claimed stratification would increase solar utilization. Because the load pump ran constantly during the heating season, the tank was never stratified. 
FINAL DESIGN

\section{I SYSTEM DESCRIPTION}

Figure 12 is a flow schematic of the Telex Communications solar system. The collectors are mounted in a field approximately 200 feet from the combination of fice, manufacturing, and warehouse building. The collector array consists of 10 rows with 36 fourfoot by eight-foot collectors in each row. The 20,000-gallon storage tank is located inside the building. Two 240-gallon-perminute pumps are used in series to transfer the water from the tank to the collector, back to a sump, and then from the sump back into the tank. Pre-insulated four-inch copper pipe is buried five feet below-grade to transfer the water to and from the collector field. Two pumps, each with 125-gallon-per-minute capacity, are used to draw the heated water from the storage tank, pass it through the coils in the air-handling units, and then return the water to the storage tank. The only heat exchanger used in this system is the air-to-water coil in the air-handling unit.

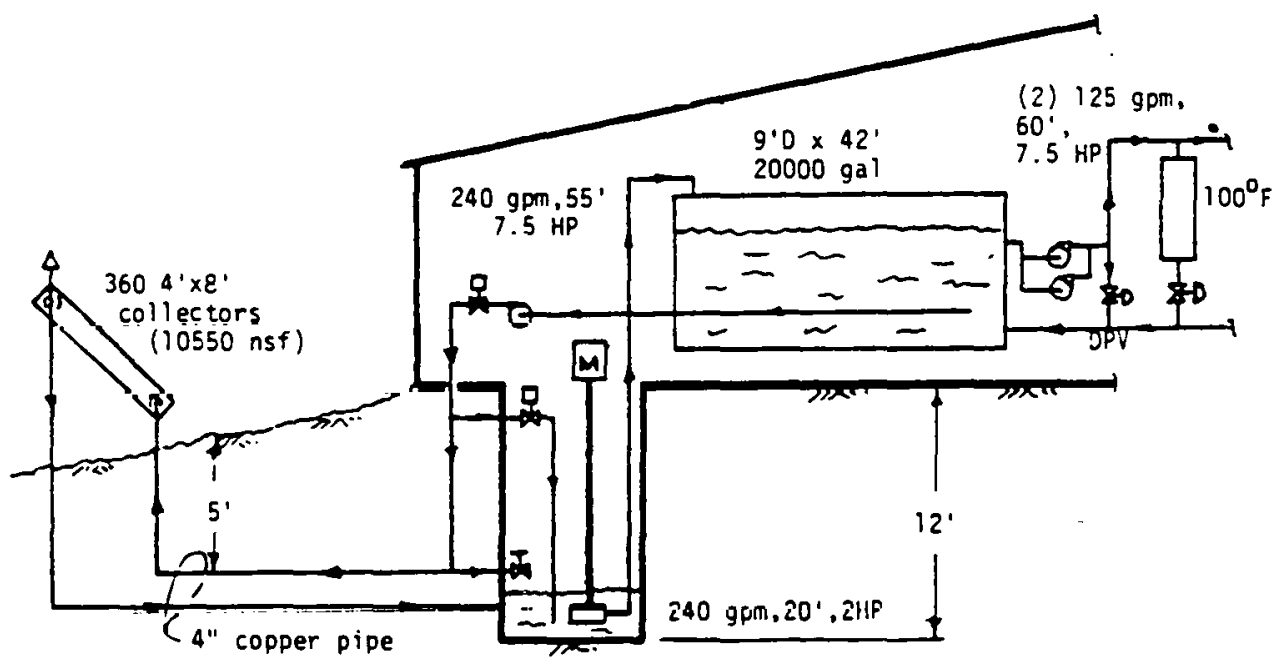

Figure 12. Telex Communications System Flow Schematic 
The simplicity of a draindown system was used to keep costs low and reliability high. However, the draindown concept in the Telex Communications case is somewhat more complicated than normally encountered. The storage tank is located at a higher elevation than the collectors. As a consequence, a sump was used to drain the collectors and a sump pump was used to transfer the water from the sump to the storage tank. Draining of the collector supply line occurs through an inverted U-tube through siphoning action. Motorized shut-off valves are used to open the U-tube and to shut the flow from the storage tank to the sump. If an air leak should develop at either of the motorized valves, the siphoning action would be precluded. In this case, the collector field will drain, but water would stand in the supply and return lines approximately 18 inches above-grade. A small bleed-line has been included in the design to permit draining of the vertical portions of the supply and return lines. This bleed-line is shown with a manually operated valve near the bottom of the sump in Figure 12. The valve is always open, so some water is bypassed directly into the sump even under normal operation. This bypass is the price one pays for a fail-safe design. The valves are selected so a power failure will result in a draining of the collectors. An engine-driven sump pump is used as a backup to the motorized pump in case of power failure. An overflow drain line is also provided in case both sump pumps fail.

The steel storage tank is phenolic-lined on the inside and covered with six inches of fiberglass on the outside.

The two pumps used to circulate water from the tank to the airhandling units are run simultaneously when heating demand is high. Only one pump is run if the demand is low. Pump operation is controlled by the position of the differential pressure valve shown in Figure 12. The solar system supplies water to the air-handing units down to $100^{\circ} \mathrm{F}$.

\section{2 KEY DESIGN TRADE-OFFS}

The selection of a draindown system represents the most significant design decision. Draindown was selected for its simplicity, low cost, and reliability. With the draindown system, no antifreeze is needed. As a consequence, water treatment is simplified and there is no need for periodic replacement of the heat-transport medium. In addition, there is no need for a heat exchanger between the collector fluid and the storage medium. Problems of pressurization during stagnation conditions are also eliminated. Without draindown, a heat dissipator is required to prevent boiling, scaling, and high pressures in the collector. These problems could persist even with a heat dissipator should there be a power failure. Therefore, draindown, with its inherent reliability, was selected.

Although draindown systems have been built and operated for many years with both aluminum and steel in contact with the fluid, the more conservative route of using copper and silicone hoses was chosen. No steel surfaces will be alternately exposed to water and air during the draindown operation. 
The single, water-white glass, black-chrome-coated collector was found to be most cost-effective. Other collectors of lower performance and lower price were considered, but the installed system cost was least for the selected collector.

The InterTechnology/Solar Corporation collector was also selected because it uses an internal manifold. The internal manifold saves approximately 3,000 feet of piping that would otherwise be required. A brief analysis will show the advantages of internal manifolding. For the Telex Communications system, two two-inch lines (on the average) would be required for each collector row. The cost of installed, insulated pipe, complete with contractor's overhead and profit, is approximately $\$ 10$ per inch of diameter per foot of length. As a consequence, the supply and return manifolds for the four-foot-side collectors would cost an average of $\$ 160$ per collector. This cost is equivalent to $\$ 5.35$ per active square foot of collector, or more than $10 \%$ of the installed system cost. Since the price of collectors with internal manifolds is approximately the same as that for collectors with external manifolds, the internal manifold is clearly cost-effective.

The disadvantages of the external manifold are increased when the heat losses from the manifolds are included. If two inches of fiberglass insulation are used, the manifolds in effect increase the loss coefficient from the collector by 0.034 BTU/hr-ft2-OF. The loss in efficiency is approximately $1.4 \%$ out of the average $44 \%$. As a consequence, approximately three percent more collector area is required to obtain the same array performance. At $\$ 20$ per additional square foot, the heat loss from a collector with external manifolds results in an additional equivalent first cost of $\$ 0.60$ per net square foot of collector for the same array performance as obtained with internal manifolding.

The primary disadvantage of the internal manifold is the inherent flow imbalance that occurs even with a reverse return. To maintain proper flow balance, the pressure drop from inlet to outlet manifold within a collector should be approximately equal to the pressure drop from beginning to end of the inlet manifold along any row of collecturs. The low pressure drop associated with the tubes of a typical collector usually results in a pressure drop through the collector being much less than the pressure drop along the manifold. To provide proper flow balance in the Telex Communications system, an internal distribution tube was placed within the supply and return manifolds. These inner tubes were sealed by silicone hoses so the flow was through the inside of the inner tube, through four $0.1=i n c h-d i a m e l e r$ holes in the ininer tube, through the annulus between the inner tube and manifold, and then through the collector tubes toward thc outlet manifold. The 0.1 -inch-diameter holes were sized to provide the desired pressure ratio and acceptable flow bal ance. 


\section{3 LESSONS LEARNED}

The following paragraph is from a paper by Frederick A. Costello of InterTechnology Corporation on the Telex Communications solar system design.

"If ITC were to do the design of the Telex Communications system again, the basic decisions pertaining to draindown and internal manifolding would be repeated. The collector choice would also be the same. The primary, unnecessary expenses encountered in this design were due to: (1) the detailed responses to the questions arising in the Critical Design Review; and (2) the redesign necessary to bring the system cost within the budget. The redesigns centered on the location of the storage tank. Originally the storage tank was to be placed below-grade near the conllector array. The cost of this arrangement exceeded the budget. The first redesign provided an above-grade tank lled lie arroy with a sump tank for draindown. This design requlred cullsideiable comploxity in the use of emergency power to prevent freezing under conditions of adverse weather and eleclicical power failure. The deaign finally chosen was the third design developed." 


\section{I DETAILS AND AS-BUILT CHANGES}

The final drawings are presented in Appendix C. A number of details of these drawings reflect changes made during construction or shortly after.

- Sheet A-4: ( $F$ igure C-4)

- Sheet A-4: (Figure $C-4$ )
The two-inch by six-inch wood braces on the back of the collectors were added in 1978 to prevent sagging.

The final drawings before construction show the supply pipe rising vertically to the bottom of the truss, rather than angling over. This was changed after the freeze-up.
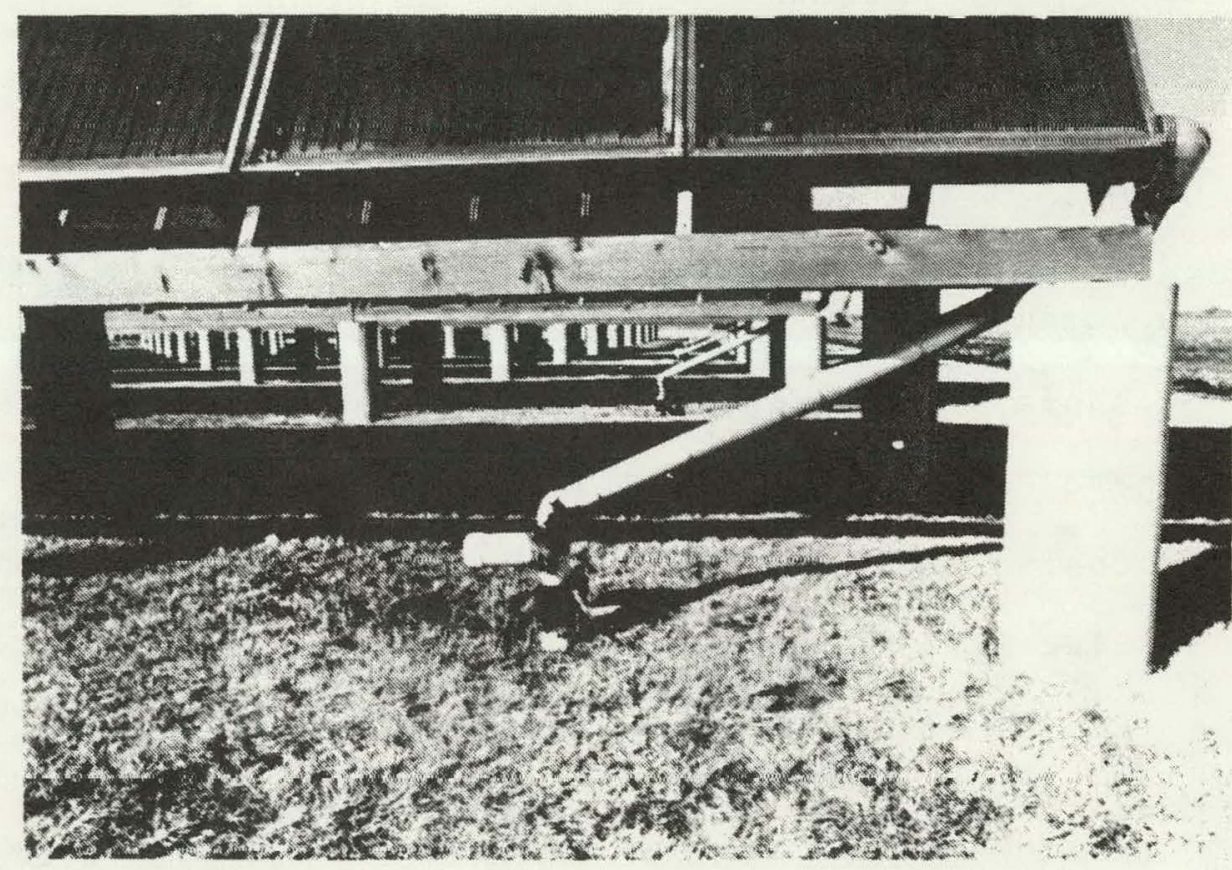

Figure 13. Collector Supply Piping

- Sheets M-2 and M-3: The system was originally built with (Figures C-7 a vacuum breaker, an auto air vent, and a and $(-8)$ pressure relief valve at the outlet of each row. After the freeze-up in December 1978 , the vacuum breakers, auto air vents, and pressure relief valves were removed and replaced by three/fourths-inch copper standpipes on each row, plus two-inch copper standpipes on Rows 1 and 10 only. 
- Sheet M-2:

(Figure $\mathrm{C}-7$ )

- Sheet $M-2$ :

(Figure $\mathrm{C}-7$ )

- Sheet M-2:

(Figure $\mathrm{C}-7$ )

- Sheet M-5:

(Figure $\mathrm{C}-10$ )
The collector supply pipe out of the storage tank, pump $P-1$, and valve $V-l$ were moved during construction from the location shown in the final design drawings.

The sump is shown on the final drawing as being 24 inches in diameter, but it is actually 36 inches.

The three/fourths-inch collector bypass 1 ine shown in the Flow Diagram was originally designed as a one/half-inch pipe.

The gasoline-powered (electric-start) emergency sump pump was originally designed as a batcery-powered electric-motor drain pump.

\section{8.? CONSTRUCTION PHASE}

Construction started on August 12, 1977 and was completed February 8,1978 . The project was organized as follows:

- Owner: Telex Communications, Inc.

- Solar Designer, Architect: InterTechnology/Solar Corporation

- Mechanical Engineer: InterTechnology/Solar Corporation

- General Contractor: Mankato Plumbing and Heating

- Subcontractors:

- Electrical: Electric Service Co.

- Pipe Insulation: General Pipe Covering

- Controls: Johnson Controls, Inc.

\section{$8.3 \operatorname{COST}$}

In the nine subsections that follow, cost information is provided for the following categories of the solar system:

- Collector Array

- Support Structure

- Piping

- Insulation

- Heating Equipment 
- Storage

- Controls

- Electrical Power

- General Construction

In each subsection, descriptions of the category are presented along with the cost components. A tabular presentation of the cost data then follows. All cost data is rounded to the nearest five-dollar increment. The data sources used for each cost item and any unique aspects are discussed along with detailed information related to the basis for the costs. This includes the identification of costs that were either unavailable or impossible to separate from the other categories. The materials and labor columns refer to costs incurred by the general contractor.

\subsubsection{Collector Array}

The collector array category includes costs associated with the purchase, delivery, handling and mounting, and piping of the collectors. Costs associated with the materials and installation of the structural frame are included in the support structure category. For the Telex Communications project, the collector array was constructed approximately 200 feet from the Telex Communications building. This array consists of 10 rows with $36 \mathrm{col}$ lectors in each row, for a total collector aperture area of 10,700 square feet. See Table 6 for collector cost data.

Table 6. COLLECTOR ARRAY CATEGORY COSTS

TELEX COMMUNICATIONS

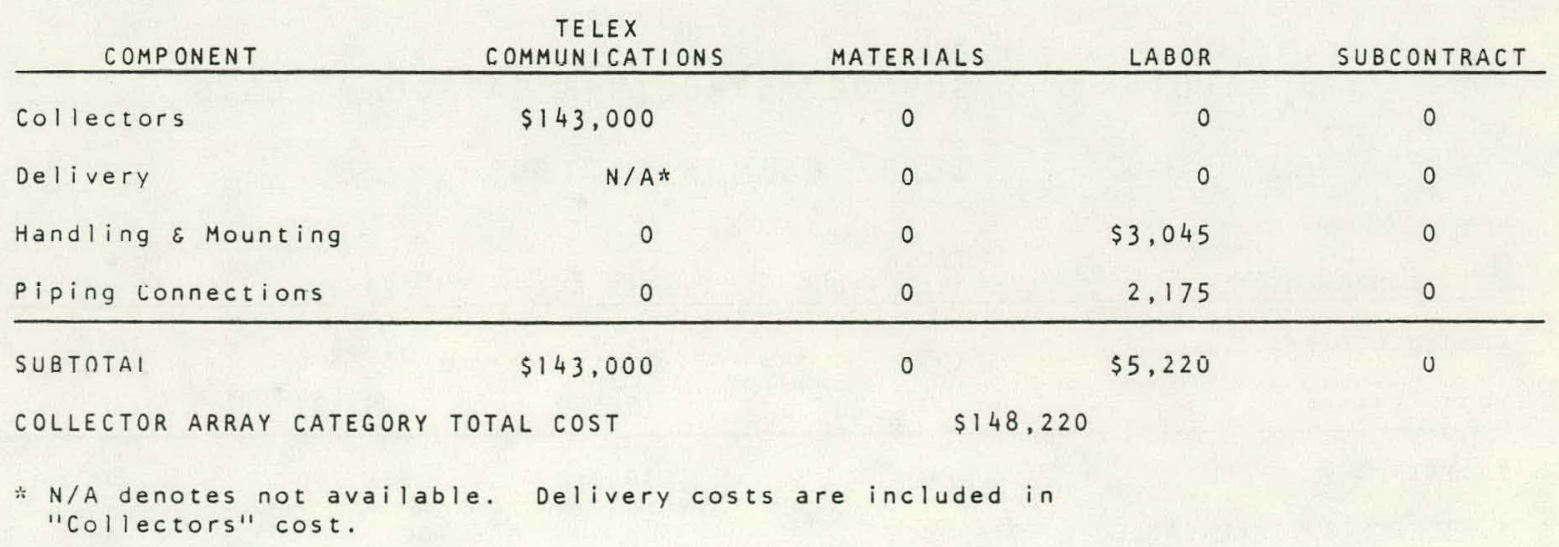


- Collector Materials

- Data source - Records of Project Manager

- Cost components - 360 ITC liquid flat-plate collectors, including glazing, enclosures, insulation, and absorber plates. The delivery costs are included in the collector costs to Telex Communications.

- Collector Labor

- Data source - Records of general contractor

- Cost components - Labor required to unload collectors

from trucks. mount on support structure, and connect collectors to cach other and external piping. Pipefitters and carpenters, with hourly wages of $\$ 11.55$ and $\$ 10.72$ respectively, installed the collectors.

\subsubsection{Support Structure}

The support structure category consists of the structural members and subassemblies used to support the collectors. At Telex Communications, the collectors were secured to a frame of treated wood trusses supported on concrete piers. Since initial construction of the support structure, the trusses have sagged considerably and support braces have been added to stop further deformation. The Project Manager feels that angle iron would have been a better choice for the frame than wood. The trusses were prefabricated, pretreated, and delivered to the site by the supplier. See Table 7 for support structure cost data. Figure 13 is a photograph showing the collector support braces and truss.

TABle 7 . SUPPORT STRUCTURE CATEGORY COSTS

TELEX COMMUNICATIONS

\begin{tabular}{lcccc}
\multicolumn{1}{c}{ COMPONENT } & $\begin{array}{c}\text { TELEX } \\
\text { COMMUNICATIONS }\end{array}$ & MATERIALS & LABOR & SUBCONTRACT \\
\hline CONCrete Piers & 0 & $\$ 15,345$ & $\$ 15,605$ & 0 \\
WOOd TrusSes & 0 & 19,565 & 5,585 & 0 \\
\hline SUBTOTAL & 0 & $\$ 34,910$ & $\$ 21,190$ & 0 \\
SUPPORT STRUCTURE CATEGORY TOTAL COST & & $\$ 56,100$ &
\end{tabular}


- Materials

- Data source - Records of general contractor

- Cost components - Concrete, reinforcing steel, wood trusses, support braces. The delivery cost for the trusses is included.

- Labor
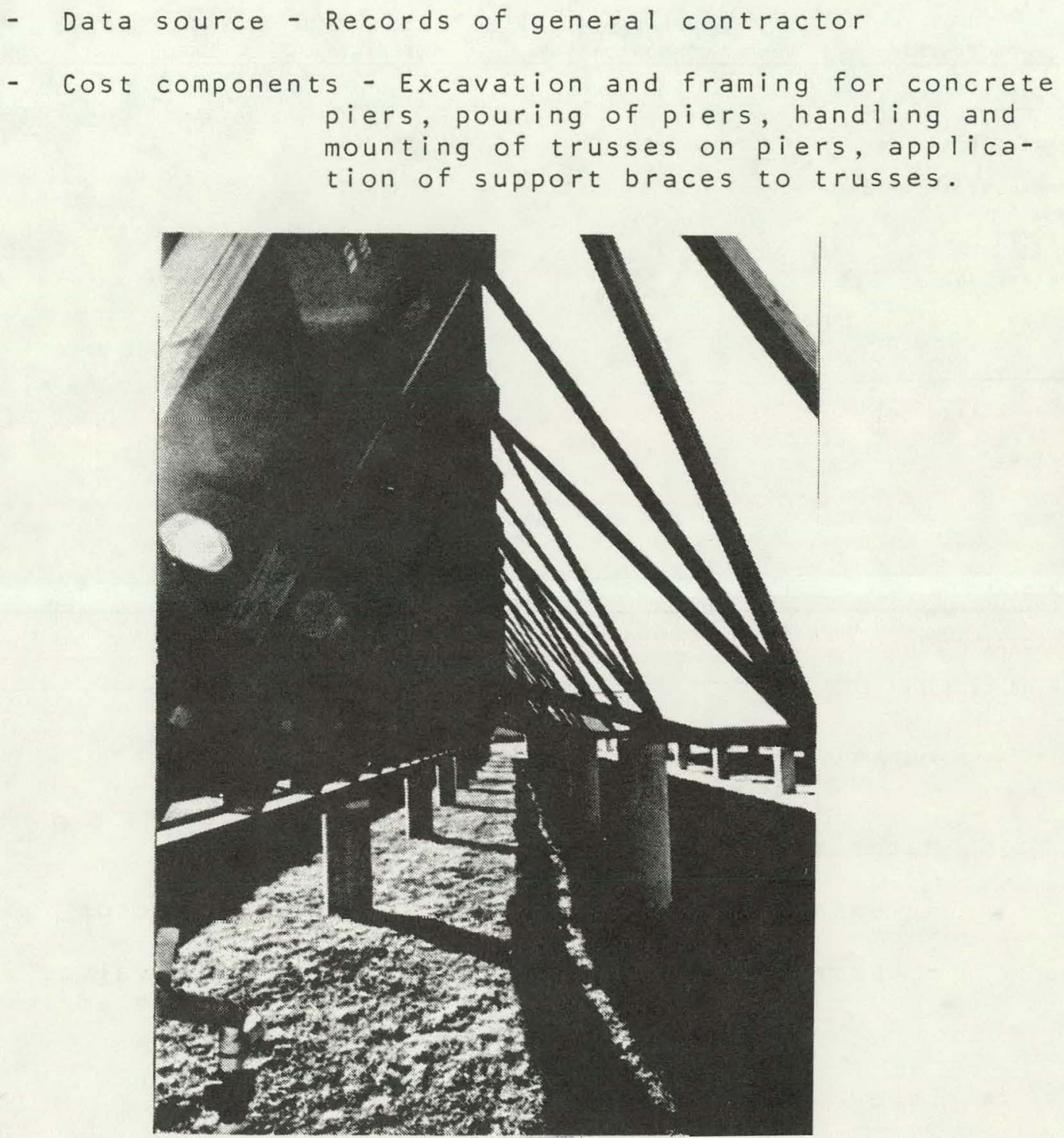

Figure 14. Collector Support Braces and Truss

\subsection{3 piping}

The piping category includes piping, valves, pumps, and miscellaneous components used to transport the system fluids. All piping labor was performed by plumbers and pipefitters at an hourly rate of $\$ 11.55$. In addition, a portion of the system controls cost is 
included in the piping valves and labor costs, since they include automatic valves and their installation. These costs could not be isolated from the other piping costs. See Table 8 for piping category costs.

\section{Table 8. PIPING CATEGORY COSTS \\ TELEX COMMUNICATIONS}

Exterior

\begin{tabular}{|c|c|c|c|c|}
\hline Pipe \& Fittings & 0 & $\$ 15,760$ & 0 & 0 \\
\hline Preinsulated Pipe & 0 & 9,205 & 0 & 0 \\
\hline Valves & $u$ & 1,000 & $u$ & 0 \\
\hline Balancing & 0 & 0 & $\$ 1,390$ & 0 \\
\hline Labor & 0 & 0 & 28,850 & 0 \\
\hline Interior & & & & \\
\hline Pipe \& Fittings & 0 & 14,330 & 0 & 0 \\
\hline Valves* & 0 & 3,155 & 0 & 0 \\
\hline Pumps & 0 & 5.055 & 0 & 0 \\
\hline Balancing & 0 & 0 & 1,740 & 0 \\
\hline Labor & 0 & 0 & 27,685 & 0 \\
\hline SUBTOTAL & 0 & $\$ 48,5 \cap 5$ & 559.665 & 0 \\
\hline PIPING CATEGORY TOTAL COST & \multicolumn{4}{|c|}{$\$ 108,170$} \\
\hline
\end{tabular}

- Materials

- Data source - Records of general contractor

- Cost components - All pipes, fittings, valves, pumps, and miscellancous hardware employed in the piping system.

- Lahor

- Data source - Records of general contractor

- Cost components - Labor required for flow balancing and installation of pipes, fittings, valves, pumps, and other piping hardware, approximately 645 man-days. 


\section{3 .4 Insulation}

The insulation category includes all insulation used in the solar system except that used on the hot water storage tank. The major portion of this category is comprised of the interior and exterior piping insulation. All of the insulation work, including that for the storage tank, was performed by a subcontractor. Preinsulated pipe was used for the piping section under the parking lot between the collector array and the building. The cost of this pipe installation is included in the piping category. See Table 9 for insulation category cost data.

\section{Table 9. INSULATION CATEGORY COSTS}

\section{TELEX COMMUNICATIONS}

\begin{tabular}{lcccc} 
COMPONENT & $\begin{array}{c}\text { TELEX } \\
\text { COMMUNICATIONS }\end{array}$ & MATERIALS & LABOR & SUBCONTRACT \\
\hline Exterior Pipe InSUlation & 0 & 0 & 0 & $\$ 4,290$ \\
Interior Pipe InSulation & 0 & 0 & 0 & 7,715 \\
\hline SUBTOTAL & 0 & 0 & 0 & $\$ 12,005$ \\
INSULATION CATEGORY TOTAL COST & & $\$ 12,005$ & &
\end{tabular}

- Insulation Subcontract

- Data source - Records of general contractor

- Cost components - All labor and materials required for the installation of the insulation, including fiberglass insulation, waterproofing, jacketing, etc. No further cost breakdown could be obtained for the insulation. subsystem.

\subsubsection{Heating Equipment}

The heating equipment category for the Telex Communications solar energy system consists of the water-to-air heating coils used to deliver heat from the storage tank to the conditioned building areas. These coils were installed upstream of the auxiliary electric heating elements in the nine air-handling units ard three unit heaters comprising the existing heating subsystem. This arrangement minimized the cost of modifying the distribution system for solar heat and also allows the use of water from storage at $80^{\circ} \mathrm{F}$ or lower. See Table 10 for heating equipment category cost data. 
Table 10. HEATING EQUIPMENT CATEGORY COSTS

\section{TELEX COMMUNICATIONS}

\begin{tabular}{lcccc} 
COMPONENT & $\begin{array}{c}\text { TELEX } \\
\text { COMMUNICATIONS }\end{array}$ & MATERIALS & LABOR & SUBCONTRACT \\
\hline Heating COIIS & 0 & $\$ 5,370$ & $\$ 3,075$ & 0 \\
\hline SUBTOTAL & 0 & $\$ 5,370$ & $\$ 3,075$ & 0 \\
HEATING/COOLING EQUIPMENT CATEGORY TOTAL COST & & $\$ 8,445$ &
\end{tabular}

- Materials

- Data source - Records of general contractor

- Cost components - Twelve water-to-air heating coils and associated pipes and fittings

- Labor

- Data source - Records of general contractor

- Cost components - All labor required for the installation of the heating coils, approximately 33 man-days. All work was performed by pipefitters and sheet-metal workers with hourly wages of $\$ 11.55$ and $\$ 11.63$, respectively.

\section{3 .6 storagc}

The storage category consists of the storage tank, supports, tank insulation, sight gauge, and miscellaneous equipment specifically related to the tank. The 20,000-gallon phenolic-lined steel tank is located on-grade in the mechanical room of the plant. The tank is insulated with six inches of fiberglass that was installed by a subcontractor after the tank was in place. See Table 11 for storage category cost data.

\section{Table 11. STORAGE CATEGORY COSTS}

TELEX COMMUNICATIONS

\begin{tabular}{lcrrr} 
COMPONENT & $\begin{array}{c}\text { TELEX } \\
\text { COMMUNICATIONS }\end{array}$ & MATERIALS & LABOR & SUBCONTRACT \\
\hline Storage Tank & 0 & $\$ 7,200$ & $\$ 2,290$ & 0 \\
Tank InSUIATion & 0 & 0 & 0 & $\$ 4,230$ \\
\hline SUBTOTAL & 0 & $\$ 7,200$ & $\$ 2,290$ & $\$ 4,230$ \\
STORAGE CATEGORY TOTAL COST & & & $\$ 13,720$ &
\end{tabular}


- Materials

- Data source - Records of general contractor

- Cost components - Tank: 20,000-gallon capacity, 5/16inch-thick hot-rolled steel, phenoliclined, cylindrical. No further breakdown of the insulation cost could be obtained.

- Labor

- Data source - Records of general contractor

- Cost components - Unloading, transfer, and setting in place of the storage tank.

\section{3 .7 Controls}

The controls category includes all equipment in the solar energy system installed for the purpose of automatically regulating system operation. The design and installation of the controls of the controls subsystem was performed by a subcontractor in accordance with the specifications of the solar system designerengineer. However, the control valves were installed by the general contractor and this cost could not be separated from the other piping costs. See Table 12 for the controls category cost data.

Table 12. CONTROLS CATEGORY COSTS

TELEX COMMUNICATIONS

\begin{tabular}{lcccc} 
COMPONENT & COMMUNICATIONS & MATERIALS & LABOR & SUBCONTRACT \\
\hline CONtrols SUbsystem & 0 & 0 & 0 & $\$ 12,435 \%$ \\
\hline SUBTOTAL & 0 & 0 & 0 & $\$ 12,435$ \\
CONTROLS CATEGORY TOTAL COST & & $\$ 12,435$ & & \\
& & & &
\end{tabular}

- Controls Subcontract

- Data source - Records of general contractor

- Cost components - Installation and wiring of the collector loop pump, sump pump, heating distribution pumps, and control panel, and wiring of the control valves. No further breakdown of the controls subsystem cost could be obtalned. 


\subsubsection{Electrical Power}

The electrical power category includes all components, materials, and labor required to install the power distribution system for the electrical energy needs of the solar system. See Table l3 for the electrical power category cost data.

Table 13. ELECTRICAL POWER CATEGORY COSTS

TELEX COMMUNICATIONS

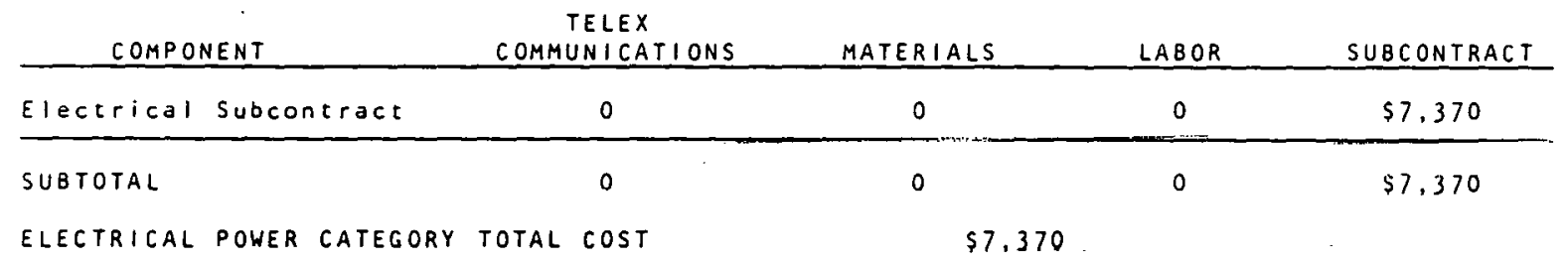

- Electrical Power Subcontract

- Data source - Records of general contractor

- Cost components - Labor and materials for power wiring of pumps and other system equipment.

\subsubsection{General Construction}

The general construction category includes all costs attributable to the solar energy system but not included in other categories. The only building space cost was for the construction of the sump pit, an unusual feature of the Telex Communigatinns system. This pit is necessary for the draindown mode since the storage tank is not below the level of the collector array. Return water from the collectors drains into the pit and is then pumped into the storage tank.

A res In-type water sottener was installed to treat the makeup water for the system. See Table 14 for the general construction ialeyury cost data. 
Table 14. GENERAL CONSTRUCTION CATEGORY COSTS

\section{TELEX COMMUN I CATI ONS}

\begin{tabular}{lcccc} 
COMPONENT & $\begin{array}{c}\text { TELEX } \\
\text { COMMUNICATIONS }\end{array}$ & MATERIALS & LABOR & SUBCONTRACT \\
\hline SUMP Pit & 0 & $\$ 4,280$ & $\$ 1,500$ & 0 \\
Water SOFtener & 0 & 1,925 & 0 & 0 \\
\hline SUBTOTAL & 0 & $\$ 6,205$ & $\$ 1,500$ & 0 \\
GENERAL CONSTRUCTION CATEG ORY TOTAL COST & & $\$ 7,705$ &
\end{tabular}

- Materials

- Data source - Records of general contractor

- Cost components - A resin-type water softener and all materials used in construction of the sump pit.

- Labor

- Data Source - Records of general contractor

- Cost components - All labor required for installation of the sump pit. 
THIS PAGE

\section{WAS INTENTIONALLY LEFT BLANK}


SECTION 9

ACCEPTANCE TESTING

\section{I TEST PLAN}

The test consisted of operating the system on a clear day and measuring the instantaneous efficiency of the collector array. The collector array efficiency was determined by measuring the total rise in storage tempoerature for one hour, with no water being circulated from the storage tank to the load. The data acquisition system was used to collect the data using the OnSite Monitor.

The data from the test was plotted as efficiency versus $\left(T_{i n}-T_{a m b}\right) / 1$. The functional relationship is:

$$
\text { Efficiency }=F_{R}(\tau \alpha)-F_{R}\left(U_{L}\right)\left(T_{i n}-T_{a m b}\right) / 1 \text {. }
$$

A range of $F_{R}(\tau \alpha)$ and $F_{R}\left(U_{L}\right)$ values that were considered acceptable was prepared. This range is depicted in Figure 15.

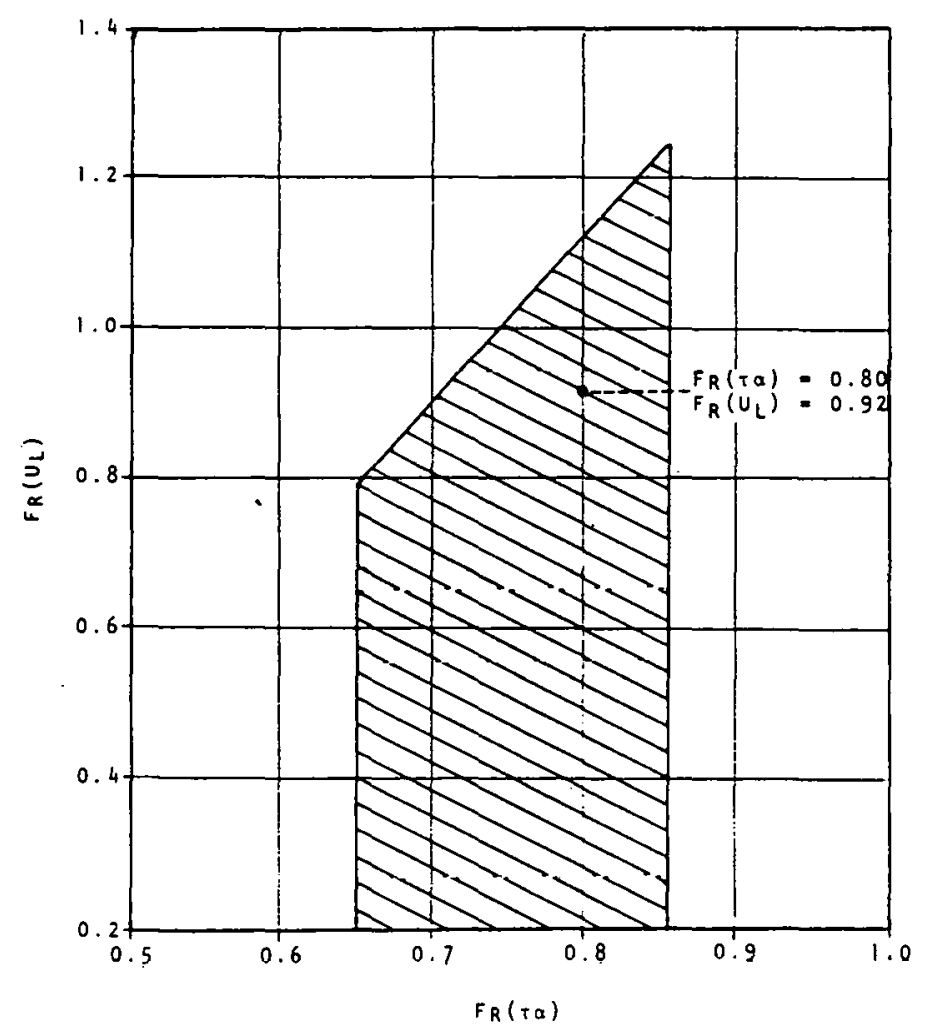

Cross-hatched area indicates acceptable values of $F_{R}(\tau a)$ and $F_{R}\left(U_{L}\right)$.

Figure 15. Manufacturer's Acceptable $F_{R}(\tau \alpha)$ and $F_{R}\left(U_{L}\right)$ Range 


\subsection{TEST RESULTS}

The acceptance test was conducted by the installation contractor, Mankato Plumbing and Heating, in June 1978. The experimentally determined values of $F_{R}(\tau \alpha)$ and $F_{R}\left(U_{L}\right)$ fell within the specified range, so the collector installation was considered acceptable. only two hours of data were used in the acceptance test, one hour from June 9 and one hour from June 26, in 1978. The performance of the collector array during these two hours is plotted in Figure 16 , on a standard collector efficiency plot. No line was drawn connecting the two points; rather, it was agreed that the two points agreed with the manufacturer's (ITC's) expected performance data (the line in Figure 16). The point marked in Figure 15 represents the manufacturer's $F_{R}(\tau \alpha)$ and $F_{R}(U L)$ values. The actual test data is shown in Tables 15 and 16 .

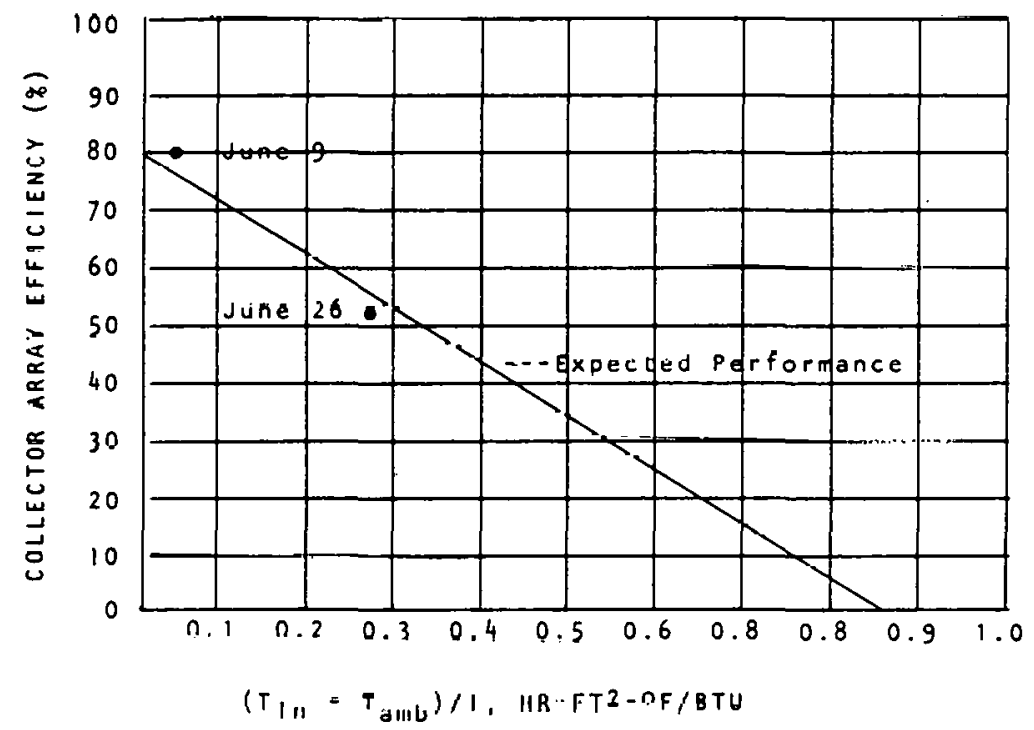

Figure 16. Collector Array Efficiency During Acceptance Test, June $\mathcal{y}$ and 26,1978

The test data taken on the Telex Communications solar heating system appears to cilosely follow the expected performance data as submitted by InterTechnology Solar Corporation. 
Table 15. JUNE 9, 1978 ACCEPTANCE TEST DATA

\section{TELEX COMMUNICATIONS}

\begin{tabular}{|c|c|c|c|c|c|c|c|}
\hline \multirow{10}{*}{$\begin{array}{l}\text { Oata } \\
\text { used } \\
\text { for } \\
\text { Test }\end{array}$} & IIAE & $\begin{array}{l}\text { IMLET } \\
\text { TEPPERATURE } \\
\text { (OF) } \\
\end{array}$ & $\begin{array}{c}\text { OUTLET } \\
\text { TEAPERATURE } \\
(\text { OF) } \\
\end{array}$ & $\begin{array}{c}\text { TEMPERATURE } \\
\text { OIFFEREMCE (AT) } \\
\text { (OF) }\end{array}$ & $\begin{array}{c}\text { AMBIENT } \\
\text { TEMPERATURE } \\
\text { (PE) } \\
\end{array}$ & $\begin{array}{r}\text { INSOLATION } \\
\text { (BTU/f(t)-hr) } \\
\end{array}$ & $\begin{array}{l}\text { Yino } \\
\text { (mph) } \\
\end{array}$ \\
\hline & $1.2: 15$ & 89 & 107 & 18 & 83 & 247 & 0.0 \\
\hline & $12: 25$ & 19 & 109 & 18 & 83 & 238 & 2.1 \\
\hline & $12: 35$ & 94 & 111 & 17 & 83 & 250 & 0.0 \\
\hline & $12: 45$ & 96 & 114 & 18 & 83 & 256 & 2.0 \\
\hline & $12: 55$ & 98 & 116 & 18 & 82 & 253 & 0.0 \\
\hline & $1: 05$ & 100 & 118 & 18 & 84 & $260^{\circ}$ & 0.0 \\
\hline & $1: 15$ & 102 & 120 & 18 & 84 & 256 & 1.2 \\
\hline & $1: 25$ & 105 & 123 & 18 & 84 & 266 & 0.7 \\
\hline & $1: 35$ & 107 & 125 & 18 & 83 & 263 & 2.1 \\
\hline
\end{tabular}

inlet water average rate of change in of $/ \mathrm{hr}=13^{\circ} \mathrm{F}$

Average at - $180 \mathrm{~F}$

Average Ambient Temperature - $83^{\circ} \mathrm{F}$

Average Insolecion - 251.43 oru/ft2-hr

Average Inlet Tomperesure - $96^{\circ} \mathrm{F}$

Efficlency $=\frac{C \Delta T}{T}+$ correction Faccor of $\frac{9.82 \times 18}{251.43}-0.70+0.09-0.79$

correction factor $=\frac{\Delta T i n}{\Delta T} \times \frac{1}{1}$ or $\frac{13}{18} \times \frac{29.7}{251.43}=0.09$

$x=\frac{(96-83)}{251.43} \cdot 0.05$

Table 16. JUNE 26, 1978 ACCEPTANCE TEST DATA

TELEX COMMUNI CATIONS

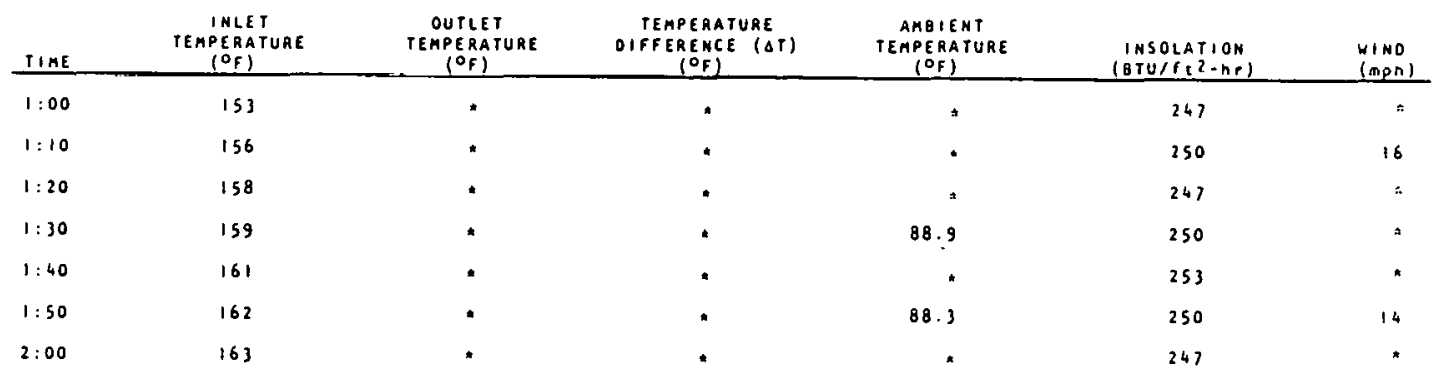

Average Insolacion - 249 gTu/fiz-hr

Average Ambienc Temperecure - od.60

Tolal change in 20,000 gallons storage temperature - $80 \mathrm{~F}$

Average Inlet Temperacure.- $1590 \mathrm{~F}$

$20,000 \times 8.33 \times 8=1.332 .800 \mathrm{BTu} / \mathrm{hr}$

$249 \times 10,692 \mathrm{fz}=2.662,308$ gru/hr

$x=\frac{(159 \cdot 89)}{249}=0.28$

Efficiency 0.50

- venotes unavalable data.

The collector array efficiency in this test was determined by measuring the total rise in storage temperature for one hour, with no water being circulated through the inside building system. Therefore, dll heat being finally collected was being retained in storage. 


\subsection{SYSTEM STARTUP PROBLEMS}

Telex Communications listed the following system startup problems in a memo dated March 13, 1978.

A. Proposed additions that Telex Communications feels should be added to correct or improve the system.

1. The existing fresh air dampers do not close tightly enough and freezestats shut down the blowers twice. cold air continues to enter the ducts after shutdown, which could freeze the water coils. Mankato Plumbing and Heating has given Telex Communications a bid of $\$ 3,065$ to install felt-tipped louvers and replace the ducts.

2. There is no protective device to prevent the collector pump from activating at night. ITC is to review this prohlem with a possible solution being the addition of a photo cell added to the pump circuit.

3. The wood trusses need strengthening to prevent sagging. Mankato Plumbing and Heating has given Telex Communications a bid of $\$ 2,034$ to correct this problem.

4. The present electrical heating system has a night thermostat mode that drops the heating temperature by $100 \mathrm{~F}$. By adding a night mode to the solar system, its efficiency could be improved and its heating time cxtended. Mankoto Plumbing and Hcoting is to review this addition and give Telex Communications a quote.

5. Telex Communications thinks a water meter should be added to the water softener line. This meter would make it possible to monitor the makeup water and manually recharge the softener, rather than letting the softener recharge at the present six-day cycle. The amount of makeup water thus tar has been very low, and recharging the softener only as needed would save on softener salt. Mankato Plumbing and Heating is to give Telex Communications a quote.

B. Items that are the responslbility of ITC

1. At present there are 35-PSI pressure relief valves on each collector row. The rubber connecting hoses will not withstand this amount of pressure, so ITC is to review this problem and glve Telex communlcations a recommendation. ITC has recommended a change to 15-PSI valves already, but this may be too high yet. Possible standpipes will be reviewed by ITC. 
2. Sealing of the collector backs and access plates. ITC has been working on a solution since october of 1977 with no recommendation as yet.

3. The collector connecting hoses are leaking. ITC to review this problem.

4. Draindown time is over one-half hour. ITC is to review this and report what conditions would have to be for any damage to occur.

5. Operating Manual. ITC will have a manual ready one month after all shop material has been supplied by Mankato Plumbing and Heating.

6. Telex Communications has been experiencing collector shutdown at the height tank temperatures. Johnson controls installed the collector sensor in the wrong location, with proper location possibly correcting this problem. If this problem continues, Telex Communications will notify ITC for review of a possible fix using a variable controlled valve on the supply line.

C. Items that are the responsibility of Mankato Plumbing and Heating

1. The high-low water level alarm has not been hooked up to anything. Telex Communications will decide if it is to be hooked up to a telephone line or an audible device installed.

2. The outside wiring of the heat tapes is temporary and has to be put in the conduit.

3. An opening is needed to put chemicals into the system. Mankato Plumbing and Heating will install an opening in the sump and a test spigot at the softener.

4. The tank insulation is not per the specifications. Mankato Plumbing and Heating is to justify the substitution.

5. The heating pump pressure differential board has not been installed by Johnson Controls as yet. Mankato plumbing and Heating is to follow-up and expedite.

6. Sealing of the construction joint on each column remains.

7. Outside cleanup and dirt leveling under the collectors remain.

8. Outside painting of the steel rellains. 
9. The automatic valve $(V-1)$ is leaking, causing the sump to cycle. Mankato Plumbing and Heating is to adjust, repair, or replace.

10. Collector row number six dips, causing a possible low spot. Mankato Plumbing and Heating to review.

11. The collector temperature sensor is located wrong. Mankato Plumbing and Heating is to have the sensor moved to the correct location.

12. The piping is to be marked for type and direction of flow by Mankato Plumbing and Heating. 
SECTION 10

SYSTEM THERMAL PERFORMANCE

\subsection{SOLAR SYSTEM}

After the freeze-up in December 1978, seven of the 10 collector rows were operational. Full operation was restored in the summer of 1979; this section will report in detail the solar system performance in the 1979-1980 and 1980-1981 heating seasons. Data collection closed on August 31,1981 .

The performance of the Telex Communications solar system in the 1979-1980 and 1980-1981 heating seasons is summarized in Tables 17 and 18, respectively. The solar fraction of the heating load was $74 \%$ in the $1979-1980$ heating season and $59 \%$ in the 1980-1981 heating season. The solar fraction in 1980-1981 would have been higher with March included, but the data system was down all of March. The solar fraction for the two seasons combined was $66 \%$, very close to the design solar fraction of $70 \%$. The ITC simulation solar fraction of $79 \%$ was based on a collector area of 13,908 square feet; the system was built with 11,520 square feet of collector area.

Table 17. SOLAR SYSTEM THERMAL PERFORMANCE

TELEX COMMUNICATI ONS

1979-1980 HEATING SEASON

(All values in million BTU, unless otherwise indicated)

\begin{tabular}{|c|c|c|c|c|c|c|c|c|c|c|}
\hline MONTH & $\begin{array}{c}\text { SOLAR } \\
\text { ENERGY } \\
\text { COLLECTEO } \\
\end{array}$ & $\begin{array}{l}\text { SYSTEM } \\
\text { LOAO } \\
\end{array}$ & $\begin{array}{l}\text { SOLAR EN } \\
\text { PREOICTEDO }\end{array}$ & $\frac{\text { GY USEO }}{\text { MEASUAED }}$ & $\begin{array}{l}\text { AUXI I IAAYY } \\
\text { ENERGY } \\
\text { ELECTRICAL }\end{array}$ & $\begin{array}{c}\text { SOLAR } \\
\text { OPERATING } \\
\text { EMERGY }\end{array}$ & $\begin{array}{c}\text { TOTAL } \\
\text { OPERATING } \\
\text { ENERGY } \\
\end{array}$ & $\begin{array}{l}\text { ENERCY } \\
\text { SAVINGS } \\
\text { ELECTRICAL }\end{array}$ & $\begin{array}{r}\text { SOLAR \&R } \\
\text { PAEDTCFET } \\
\text { PREDCTET }\end{array}$ & $\begin{array}{l}\text { ACTION } \\
\text { MEASUAEO }\end{array}$ \\
\hline nov & 74.5 & 85.6 & 64.5 & 17.7 & 0.19 & 7.18 & 8.97 & 70.6 & 82 & $9 !$ \\
\hline aec & 100 & 122 & 79.3 & 103 & 2.98 & 13.2 & 20.0 & 89.4 & 47 & 84 \\
\hline JAM & 80.9 & 164 & 72.8 & 69.6 & 55.0 & 13.0 & 22.0 & 56.6 & 29 & 48 \\
\hline FEB & 112 & 154 & 112 & 102 & 37.5 & 12.3 & 17.6 & 89.6 & 64 & 66 \\
\hline MAR & 143 & 153 & 118 & 125 & 12.1 & 13.4 & 19.7 & 112 & 85 & 82 \\
\hline APA & 70.6 & 61.3 & 43.2 & 53.7 & 0.95 & 7.53 & 9.17 & 46.1 & 100 & 88 \\
\hline TAL & 587 & 720 & 488 & 531 & 109 & 66.6 & 97.3 & 464 & - & . \\
\hline AVE RAGE & 97.8 & 120 & 81.3 & 88.4 & 18.2 & 11.1 & 16.2 & $77: 3$ & 64 & 74 \\
\hline
\end{tabular}

1 prodiced performance was docermined from a modilied i-chart compucer simulatlon using measured weatner, measured syosyscem loads. ana computed loads as inpus. 
Table 18. SOLAR SYSTEM THERMAL PERFORMANCE

TELEX COMMUNICATIONS

1980-1981 HEATING SEASON

(All values in million BTU, unless otherwise indicated)

\begin{tabular}{|c|c|c|c|c|c|c|c|}
\hline NONTH & $\begin{array}{c}\text { SOLAR } \\
\text { EMERGY } \\
\text { COLLECTED } \\
\end{array}$ & $\begin{array}{l}\text { SYSTEN } \\
\text { LOAD } \\
\end{array}$ & $\begin{array}{l}\text { SOLAR } \\
\text { ENERGY } \\
\text { USED } \\
\end{array}$ & $\begin{array}{c}\text { AUXILIAAY } \\
\text { ENERGY } \\
\text { ELECTRICAL } \\
\end{array}$ & $\begin{array}{c}\text { TOTAL } \\
\text { OPERATING } \\
\text { EMEAGY }\end{array}$ & $\begin{array}{l}\text { ENERGY } \\
\text { SAVINGS } \\
\text { ELECTRICAL }\end{array}$ & $\begin{array}{c}\text { SOLAR } \\
\text { FAACTION } \\
(\xi)\end{array}$ \\
\hline$O C T$ & 37.0 & 33.8 & 32.8 & 0.01 & 2.12 & 31.1 & 97 \\
\hline NOV & 111 & 127 & 118 & 0.40 & 10.4 & 110 & 93 \\
\hline DEC & 56.3 & 167 & 58.2 & 72.1 & 19.5 & 46.3 & 40 \\
\hline Jan & 152 & 259 & 148 & 95.9 & 18.7 & 136 & 57 \\
\hline$F E B$ & 109 & 233 & 109 & 113 & 19.2 & $x \cdot 3$ & 47 \\
\hline Man & 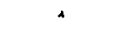 & - & - & 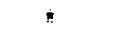 & " & " & - \\
\hline APA & 6.50 & 13.8 & 13.3 & 0.10 & 1.34 & 11.8 & ;0 \\
\hline TOTAL & 471 & 813 & 479 & 281 & 67.2 & 432 & - \\
\hline AVERAGE & 78.5 & Is & 19.0 & 46.9 & $1 ! . ?$ & 71.0 & 59 \\
\hline
\end{tabular}

- Denores unavailable oara.

Collector performance was invariably good; perhaps the pump could have started earlier in the day, but the overall efficiency was one of the best of the NSDN systems.

The solar space heating distribution system also worked well, transferring the collected energy to the load with continuously running pumps. Over the two heating seasons, there were 4,720 million BTU of solar energy incldent on the collectors, and 1,009 milliun BTU, or $21 \%$ of the incident energy, went to the loads. For the months of December through February, this fraction was $28 \%$ over the two seasons. Thc main factor limiting the efficiency of the system was the collector control operation. Over the two seasons, only $51 \%$ of the incident solar energy fell while the collector pump was running, and even in December through February this figure was only $66 \%$ compared to about $80 \%$ at most NSDN buldisystems.

The flow of energy through the Telex Communications solar system for the period November 1979 through April 1980, and October 1980 through April 1981 (except March 1981) is presented in Figure 17. This Energy Flow Diagram shows the amount of energy collected, transported, stored, consumed, or lost at each point in the system. The number for energy out of storage ( 916 million BTU) was calculated from storage energy in and tank losses calculated with an empirical storage tank UA, The measured energy out of storage was too large, implying negative tank losses. All the space heating operating energy, and the motor losses from the collector pumps, are assumed to contribute to the space heating load. The losses from the indoor storage tank also contribute to the space heating load. Collector-to-storage piping losses do not contribute to the space heating load; they are warming the soil beneath the parking lot. 


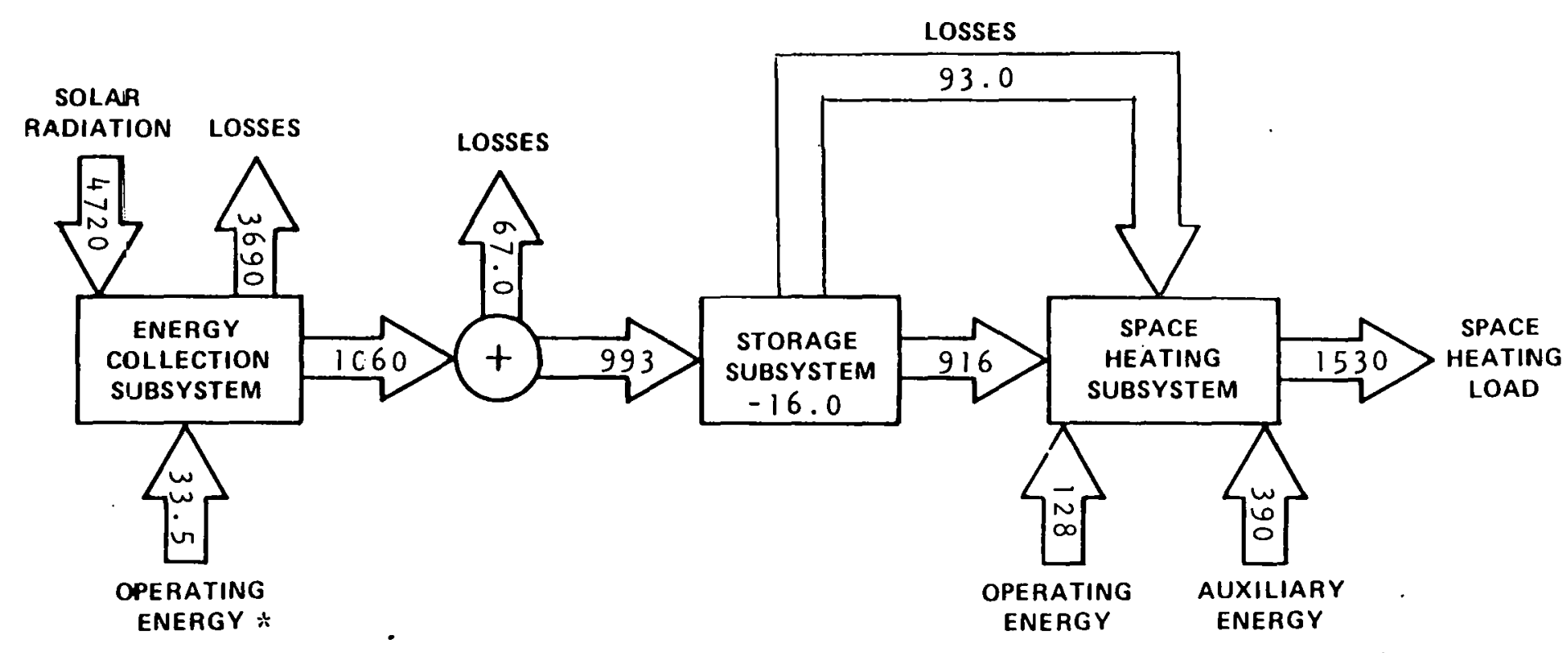

* Six million BTU motor losses contributed to space heating load.

Figure 17. Energy Flow Diagram for Telex Communications $1979-1981$

(A) l figures in million BTU) 


\subsection{PREDICTED VERSUS ACTUAL}

A TRNSYS simulation of the Telex Communications solar system was performed by IBM in January 1977. This simulation was the most detailed prediction of the thermal performance that was made, but it modeled the ITC design at that time, which was not the same as the final design. The system that was modeled had a collector area of 13,908 square feet; the system was built with 11,520 square feet of collectors, $17 \%$ less area. The modeled storage tank was underground, with a volume of 29,796 gallons, filled with 23,000 gallons of water. The actual tank, inside the building, has a capacity of 20,000 gallons, filled with 18,000 gallons of water. This simulation, which predicted a solar fraction of $90 \%$, was run with no minimum tank temperature. As this model did not reflect the actual as-built system, no further discussion will be presented, but IBM's analysis is included in Appendix E.

The as-built system was modeled using f-Chart Version 5.3. The manufacturer's collector performance parameters, together with measured loads, temperatures, and insolation data were used in this model. The f-Chart model predicted a solar fraction of $64 \%$ for the 1979-1980 season; the measured solar fraction was better, $74 \%$.

The building load calculated by the UACd method (ASHRAE 1980 Systems, Page 43.8) is presented in Tables 19, 20 , and 21 for the 1978-1979, 1979-1980, and 1980-1981 heating seasons, respectively. The agreement between the calculated and measured values is very good for the period December 1978 through March 1979. In this period, very little solar energy was used because of the collector freezeup in edrly December 1978. The measured values represent mostly electrical resistance energy, so they should be accurate. This implies that the design UACd value of $7,300 \mathrm{BTU} /$ hr-OF is a good value. In the heating season of 1979-1980, the measured values are consistently lower than the design values. In the 1980-1981 winter, the agreement is again good, except for the month of December. This is hard to understand, especially because total electrical usage was actually less in December 1980 than in November 1980. As there was only one indoor temperature sensor in the 97,000-square-fout building, it may be that the buildinq was just a bit cooler in December than in the other mantha. 
Table 19. BUILDING LOAD CALCULATED BY THE UAC METHOD

TELEX COMMUNICATIONS

1978-1979 HEATING SEASON

\begin{tabular}{|c|c|c|c|c|c|c|}
\hline MONTH & $\begin{array}{c}\text { BUILOINE } \\
\text { TEMPERATUAE } \\
\text { (OF) } \\
\end{array}$ & $\begin{array}{c}\text { AMBIENT } \\
\text { TEMPERATURE } \\
\text { (OF) }\end{array}$ & $\begin{array}{c}\text { HEATING } \\
\text { DEGAEE- DAYS } \\
\left(65^{\circ} \mathrm{F} \text { REF) }\right. \\
\end{array}$ & $\begin{array}{c}\text { UA } x \text { Cd VALUE } \\
\text { (BTU/hr-OF) }\end{array}$ & $\begin{array}{l}\text { DESIGN } \\
\text { HEAT LOAD } \\
\text { (BTU } \times 106) \\
\end{array}$ & $\begin{array}{r}\text { MEASURED } \\
\text { LOAD } \\
\text { (BTU } \times 106) \\
\end{array}$ \\
\hline nOV & 74 & 30 & 1,050 & 7.300 & 184 & 108 \\
\hline$D E C$ & 72 & 13 & 1,612 & 7.300 & 282 & 282 \\
\hline JAN & 70 & 0 & 2,015 & 7,300 & 353 & 351 \\
\hline$f \in B$ & 70 & 7 & 1,624 & 7.300 & 285 & 281 \\
\hline MAR & 73 & 26 & 1,209 & 7.300 & 212 & 211 \\
\hline TOTAL & - & - & 7.510 & & 1.320 & 1.230 \\
\hline AVERAGE & 72 & 15 & 1,502 & 7,300 & 263 & 247 \\
\hline
\end{tabular}

Table 20. BUILDING LOAD CALCULATED BY THE UAC d METHOD

TELEX COMMUNICATI ONS

1979-1980 HEATING SEASON

\begin{tabular}{|c|c|c|c|c|c|c|}
\hline MONTH & $\begin{array}{l}\text { BUILOING } \\
\text { TEMPEAATURE } \\
\text { (OF) }\end{array}$ & $\begin{array}{l}\text { ANQIENT } \\
\text { TEMPEAATUAE } \\
\text { (OF) }\end{array}$ & $\begin{array}{l}\text { HEATING } \\
\text { OEGREE - DAYS } \\
\text { (65OF REF) }\end{array}$ & $\begin{array}{c}\text { UA } X C D \text { VACUE } \\
\text { (BTU/AROCE) }\end{array}$ & $\begin{array}{r}\text { DESIGN } \\
\text { MEAT LOAO } \\
\text { (BTU } \times 106) \\
\end{array}$ & $\begin{array}{l}\text { MEASURED } \\
\text { LOAD } \\
\text { (BTU } \times 106)\end{array}$ \\
\hline nov & 11 & 32 & 992 & 7.300 & 174 & 85.6 \\
\hline OEC & 69 & 26 & 1,219 & 7.300 & 214 & 122 \\
\hline JAN & 69 & 16 & 1,505 & 7.300 & 264 & 144 \\
\hline FE 8 & 68 & 16 & 1,427 & 7.300 & 250 & 154 \\
\hline MAR & 69 & 28 & 1.138 & 7.300 & 199 & 153 \\
\hline APR & 73 & 48 & 531 & 7.300 & 93.0 & 61.3 \\
\hline TOTAL & - & - & 6,812 & - & 1,193 & 720 \\
\hline AVERAGE & 70 & 28 & 1,135 & 7,300 & 199 & 120 \\
\hline
\end{tabular}


TELEX COMMUNICATIONS

1980-1981 HEATING SEASON

\begin{tabular}{|c|c|c|c|c|c|c|}
\hline MONTK & $\begin{array}{l}\text { BUILOING } \\
\text { TEMPERATURE } \\
\text { (OF) } \\
\end{array}$ & $\begin{array}{c}\text { AMBIENT } \\
\text { TEMPERATURE } \\
\text { (OF) }\end{array}$ & $\begin{array}{l}\text { HEATING } \\
\text { DEGREE-DAYS } \\
\text { (65\% REF) }\end{array}$ & $\begin{array}{l}\text { UA } \times \text { CD VALUE } \\
(B T U / h r=O F)\end{array}$ & $\begin{array}{c}\text { DESIGN } \\
\text { HEAT COAD } \\
\text { (BTU } \times 106) \\
\end{array}$ & $\begin{array}{r}\text { MEASURED } \\
\text { COAO } \\
\text { (BTU } \times 106) \\
\end{array}$ \\
\hline OCT & 74 & 49 & 485 & 7.300 & 85.0 & 33.8 \\
\hline NOV & 73 & 28 & 735 & 7,300 & 129 & 127 \\
\hline DEC & 66 & 20 & 1.391 & 7.300 & 244 & 147 \\
\hline JAN & 68 & 19 & 1.428 & 7.300 & 250 & 259 \\
\hline FEB & 69 & 21 & 1.167 & 7.300 & 204 & 233 \\
\hline MAR & " & $\star$ & $\star$ & $\star$ & * & * \\
\hline AP $A$ & 73 & 50 & 401 & 1.300 & 77.3 & 13.8 \\
\hline TOTAL & - & - & 5.647 & - & 989 & 813 \\
\hline AYE RALiE & 71 & 30 & 941 & 7.300 & 165 & 136 \\
\hline
\end{tabular}

- Denotes unavaliable data.

\subsection{SOLAR SUBSYSTEM}

\section{3 .1 Collection}

The Telex Communications collector array has 360 panels in cen rows sloped at 38.3 degrees, with a cocal area ol 11,520 syudie feel. There is a 3/4-inch collector bypass which will drain the vertical portion of the collector-to-storage piping in the event of an air leak in the motorized valves. The flow out of the storage tank is usually 240 gallons per minute. The flow through the collector is less by the amount of bypass flow, which was measured in the spring of 1981 at 26 gallons per minute.

Collection subsystem performance is presented in Tables 22 and 23. Over the two heating seasons, the average collector efficiency was $22 \%$, and the average operational collector efflciency was $44 \%$. To better explain the performance of the collector subsystem, the operation of the collectors on a clear day (January 29, 1981) is presented in Figure 18 . 
Table 22. COLLECTION SUBSYSTEM PERFORMANCE

TELEX COMMUNICATI ONS

1979-1980 HEATING SEASON

(Al) values in million BTU, unless otherwise indicated)

\begin{tabular}{|c|c|c|c|c|c|c|c|c|}
\hline MONTH & $\begin{array}{l}\text { IMGIOENT } \\
\text { SOLAR } \\
\text { RADIATIOA }\end{array}$ & $\begin{array}{c}\text { COLLECTED } \\
\text { SOLAR } \\
\text { ENERGY } \\
\end{array}$ & $\begin{array}{l}\text { COLLECTOA } \\
\text { EFFICIEACY } \\
\text { (\&) }\end{array}$ & $\begin{array}{c}\text { OPERATI OMAL } \\
\text { INCIDEMT } \\
\text { ENERGY } \\
\end{array}$ & $\begin{array}{c}\text { OPERATIONAL } \\
\text { COLLECTOR } \\
\text { EFICIENCY } \\
(\&)\end{array}$ & $\begin{array}{c}\text { ECSS } \\
\text { OPERATING } \\
\text { ENERGY } \\
\end{array}$ & $\begin{array}{r}\text { SOLAR ENERGV } \\
\text { TO STORAGE } \\
\end{array}$ & $\begin{array}{c}\text { DAYTIME } \\
\text { AMQIENT } \\
\text { TEMPEATER } \\
\text { OFF) } \\
\text { OFA }\end{array}$ \\
\hline nov & $320 \%$ & 74.5 & 23 & 176 & 42 & 1.48 & 62.9 & 35 \\
\hline DEC & 308 & 106 & 34 & 229 & 46 & 3.98 & 99.6 & 30 \\
\hline JAM & 266 & 80.9 & 30 & 157 & 52 & 3.28 & 80.0 & 19 \\
\hline FEO & 408 & 112 & 27 & 257 & 44 & 3.89 & 102 & 20 \\
\hline MAR & 455 & 143 & 31 & 293 & 49 & 4.34 & 128 & 32 \\
\hline APR & 511 & 10.6 & 14 & 159 & 44 & 2.93 & 59.2 & 54 \\
\hline TOTAL & 2,270 & 587 & - & 1.270 & - & 19.9 & 531 & - \\
\hline AVERAGE & 378 & 97.8 & 26 & 212 & 46 & 3.32 & 88.6 & 32 \\
\hline
\end{tabular}

Table 23. COLLECTION SUBSYSTEM PERFORMANCE

TELEX COMMUNICATIONS '

1980-1981 HEATING SEASON

(All values in million BTU, unless otherwise indicated)

\begin{tabular}{|c|c|c|c|c|c|c|c|c|}
\hline NONTH & $\begin{array}{c}\text { INCIOENT } \\
\text { SOLAR } \\
\text { RADIATION } \\
\end{array}$ & $\begin{array}{c}\text { COLLECTED } \\
\text { SOLAR } \\
\text { ENERCY } \\
\end{array}$ & $\begin{array}{c}\text { COLLECTOR } \\
\text { EFFICIENCY } \\
\end{array}$ & $\begin{array}{c}\text { OPERATIOMAL } \\
\text { INCLEMT } \\
\text { EMERGY } \\
\end{array}$ & $\begin{array}{c}\text { OPERATIONAL } \\
\text { COLLECTOR } \\
\text { EFFICIENCY } \\
\text { (z) }\end{array}$ & $\begin{array}{l}\text { ECSS } \\
\text { OPERATING } \\
\text { ENERGY } \\
\end{array}$ & $\begin{array}{l}\text { SOLAR ENERGY } \\
\text { TO SORAGE } \\
\end{array}$ & $\begin{array}{c}\text { OAYTIME } \\
\text { AMBIENT } \\
\text { TEMPERATURE } \\
\text { (OF) } \\
\end{array}$ \\
\hline OCT & 493 & 37.0 & 8 & 131 & 28 & 0.97 & 35.2 & 68 \\
\hline nov & 453 & 111 & 24 & 274 & 41 & 1.33 & 105 & 53 \\
\hline$D E C$ & 224 & 56.3 & 25 & 135 & 42 & 2.30 & 55.2 & 46 \\
\hline JAN & 473 & 152 & 32 & 334 & 45 & 3.28 & 152 & 25 \\
\hline$F \in B$ & 404 & 109 & 27 & 247 & 44 & 4.56 & 109 & 25 \\
\hline MAR & $\cdot *$ & " & • & " & " & " & * & " \\
\hline APR & 406 & 6.50 & 2 & $*$ & • & 1.19 & 6.05 & 57 \\
\hline TOTAL & 2,450 & 471 & - & 1,120 & - & 13.6 & 462 & - \\
\hline AVERAGE & 409 & 78.5 & 19 & 224 & 41 & 2.27 & 77.0 & 46 \\
\hline
\end{tabular}

- Denoces unarailable daca. 


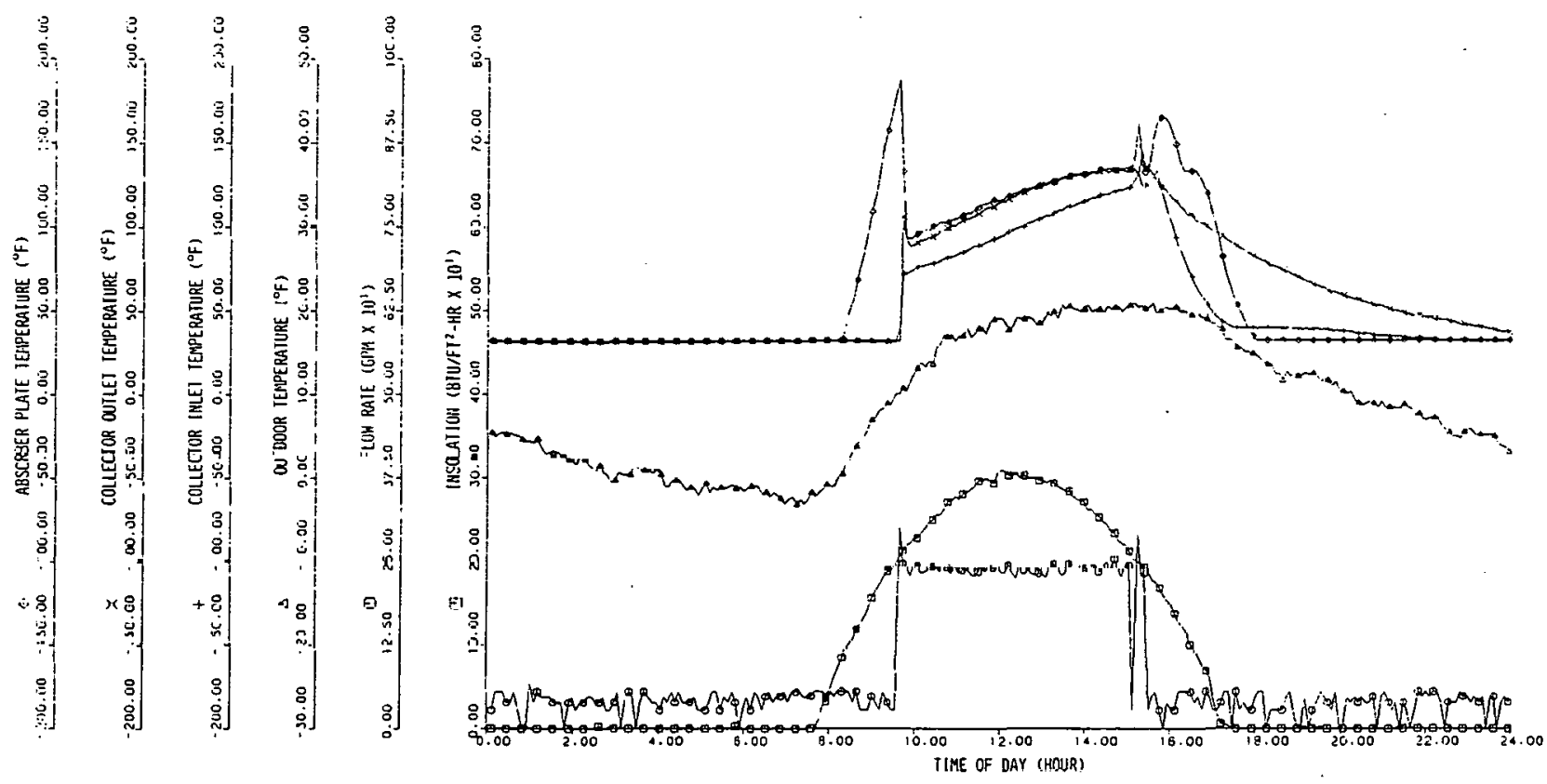

Figure 18. Piot of Collector Pertormance, and Absorber Plate, Collector outlet and Inlet, and Outdoor Temperatures

Telex Communications January 29,1981

It was a clear day, with measured insolation first occurring at 7:46 a.m., peaking at 309 BTU/ft2-hr at 12:02 p.m., and dropping back to zero at $5: 23 \mathrm{p} . \mathrm{m}$. The total insolation for the day was 1,971 BTL/ft2. Solar radiation on the collectors was enhanced by a light snow cover on the ground. The weather was seasonably cold, with an overnight low temperature of $-3^{\circ} \mathrm{F}$ at 7:00 a.m., and a high temperature of $21{ }^{\circ} \mathrm{F}$ at $3: 30 \mathrm{p} . \mathrm{m}$. Winds were lighter than usual, averaging three mph for the day, usually running about seven to $12 \mathrm{mph}$ during the period of collector operation. The collector pump first turned on at $9: 38$ a.m., when insolation was 206 BTU/ft2a hr. The collector plate temperature was $188^{\circ} \mathrm{F}$, and the storage tank temperature was $75^{\circ} \mathrm{F}$. The pump could have started earlier, say at 8:56 a.m., with insolation of 145 BTU/ft2-hr and a collector absorber plate temperature of 1000F. At $9: 54$ a.m., operation had settled down, and, with insolation of 222 BTU/fiz-hr, the cullector array inlet temperature was $76^{\circ} \mathrm{F}$, and the outlet temperature was $880 \mathrm{~F}$. The flow through the collector array was $220 \mathrm{gallons}$ per minute. The collector efficiency was $52 \%$ at this time, with a collector operating point of 0.29 . At 12:02 p.m., the peak insolation time, the collector in let temperature was $970 \mathrm{~F}$, the outlet temperature was $115^{\circ} \mathrm{F}$, with a flow rate of $218 \mathrm{gpm}$. This is a collection rate of $1,880,000$ BTU/hr, with insolation of $3,560,000$ BTU/hr, or $53 \%$ efficiency. The collector outlet temperature peaked at $1340 \mathrm{~F}$ 
at $2: 30 \mathrm{p} . \mathrm{m}$. The collector pumps ran steadily until $3: 05 \mathrm{p} . \mathrm{m}$. , when they cycled off for a couple of minutes, even though insolation was high (210 BTU/ft2-hr) and uninterrupted by clouds. When the pump shut off, the absorber plate temperature was $134^{\circ} \mathrm{F}$, and the storage temperature was $1260^{\circ} \mathrm{F}$. These sensors are not in the same location as the control sensors. The system cycled on and off twice between $3: 05 \mathrm{p} . \mathrm{m}$. and $3: 20 \mathrm{p} . \mathrm{m}$., and twice more after $3: 30 \mathrm{p} . \mathrm{m}$. before shutting down for the day at $3: 45 \mathrm{p} . \mathrm{m}$. At this final shutdown time, the absorber temperature was $133^{\circ} \mathrm{F}$, then it rose to $165^{\circ} \mathrm{F}$ at $3: 51 \mathrm{p} . \mathrm{m}$. With the pump off. There was still a $7^{\circ} \mathrm{F}$ rise across the coll lector array when the pump shut down at $3: 45$ p.m., with insolation of 168 BTU/ft2-hr. The storage tank temperature was $129^{\circ} \mathrm{F}$ at shutdown, a rise of $54^{\circ} \mathrm{F}$ for the day. The operating point at shutdown was 0.65 . At this operating point, the collector efficiency should be about $25 \%$, so it was about time for the collectors to shut down. For the day, total collection was $9.12 \mathrm{million}$ BTU, out of $22.7 \mathrm{milli}$ on BTU incident energy, and $17.7 \mathrm{milli}$ on BTU incident during collector operation. The overall efficiency was $40 \%$, and the operational efficiency was $52 \%$.

Although the pump could have started 40 minutes earlier, this is very fine performance, and the low ratio of operational incident to total incident energy that shows up in monthly totals is not much in evidence on this day. This problem shows up more on partly cloudy days such as January 23,1981 , discussed in Section 11.2 .1 .

The operation of the collector array can be seen in Figure 19, a collector efficiency plot for January 1981. The line on the graph is plotted from the manufacturer's ASHRAE test parameter. The measured data falls right on the line, a very good performance for a large array, where the flow must be perfectly balanced in order to achieve design performance.

The flow through the collector array was just about equal to the "rule-of-thumb" value of $230 \mathrm{gpm}$, or $0.02 \mathrm{gpm}$ per square foot of collector. 


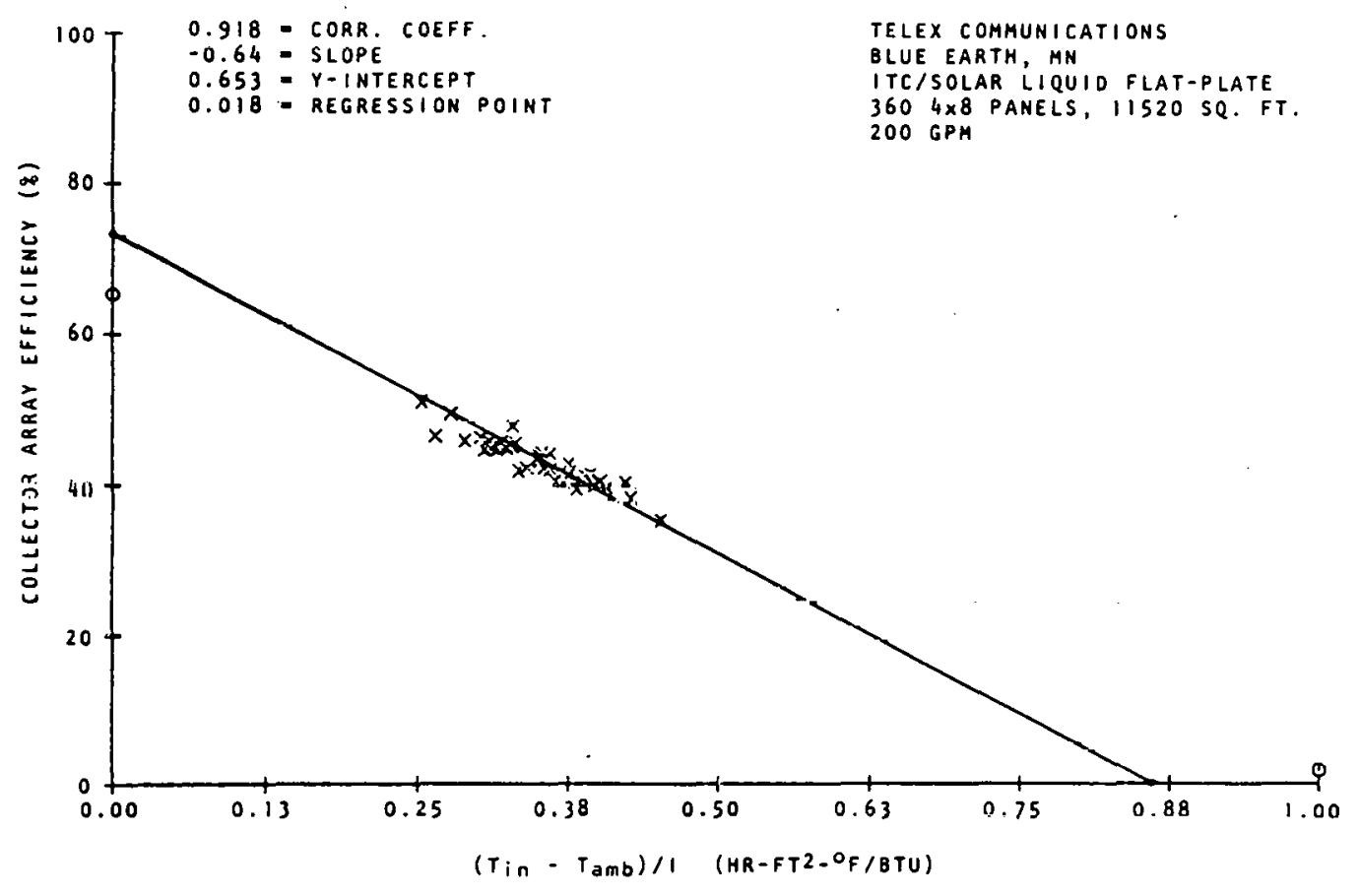

Figure 19. Average Collector Efficiency

Telex Communications

January 1981

\section{3 .2 storage}

Thermal storage for the solar system is provided by a 20,000-gallon steel water storage tank inside the building. The tank is nine feet in diameter and 42 feet long, insulated with six inches of fiberglass. Storage performance for the two heating seasons, 19791980 and 1980-1981 is presented in Tables 24 and 25 . The measured energy out of storage was regularly greater than the measured energy into storage. The measured energy into storage is generally in good agreement with the collected solar energy measurement, but there is no check (other than design heating load - a very rough check) on the measured energy out of storage. The temperature difference between the load supply and return is small, only about $3^{\circ} \mathrm{F}$. The accuracy in the sensors is $\pm 0.5^{\circ} \mathrm{F}$, so the energy out of storage is not a very accurate measurement.

The energy from storage, energy loss, and storage efficiency reported here are calculated values. The values shown were calculated by assuming that the energy into storage (STEI) and the change in stored energy (STECH) were correct, and that storage losses were known. Then the energy out of storage (STEO) = STEI - STECH - STLOSS. 
Table 24. STORAGE SUBSYSTEM PERFORMANCE

TELEX COMMUNICATIONS

1979-1980 HEATING SEASON

(All values in million BTU, unless otherwise indicated)

\begin{tabular}{|c|c|c|c|c|c|c|c|}
\hline MONTH & $\begin{array}{l}\text { ENERGY } \\
\text { TO } \\
\text { STORAGE } \\
\end{array}$ & $\begin{array}{c}\text { ENERGY } \\
\text { FROA } \\
\text { STORACE } \\
\text { (CALCULATED) } \\
\end{array}$ & $\begin{array}{c}\text { ENERGY } \\
\text { FROM } \\
\text { STORAGE } \\
\text { (NEASURED) } \\
\end{array}$ & $\begin{array}{l}\text { CHANGE IN } \\
\text { STOREO } \\
\text { ENERCY } \\
\end{array}$ & $\begin{array}{c}\text { STORAGE } \\
\text { EFFICIENCY } \\
\text { (\&) } \\
\end{array}$ & $\begin{array}{c}\text { AVERACE } \\
\text { STORACE } \\
\text { TEAPERATURE } \\
\text { (OF) }\end{array}$ & $\begin{array}{l}\text { LOSS FROM } \\
\text { STORAGE } \\
\text { (CALCULATED FROM } \\
\text { EMPIRICAL UA) } \\
\end{array}$ \\
\hline nov & 62.9 & 68.7 & 73.0 & -14.9 & 86 & $14+35$ & 9.09 \\
\hline DEC & 99.6 & 97.8 & 117 & -3.04 & 95 & 98 & 4.89 \\
\hline JAN & 80.0 & 66.7 & 82.2 & 10.4 & 96 & 82 & 2.83 \\
\hline$f \in B$ & 102 & 94.4 & 105 & 0.21 & 93 & 122 & 7.46 \\
\hline MAR & 128 & 118 & 133 & 2.42 & 94 & 118 & 7.46 \\
\hline$A P R$ & 59.2 & 42.2 & 45.5 & 5.56 & 81 & 158 & 11.5 \\
\hline TOTAL & 531 & 487 & $\$ 56$ & 0.71 & - & - & 43.2 \\
\hline AVERAGE & 88.6 & 81.2 & 92.6 & 0.12 & 92 & 119 & 7.20 \\
\hline
\end{tabular}

1 Basod on calculaled energy from storage.

Table 25. STORAGE SUBSYSTEM PERFORMANCE

TELEX COMMUNICATIONS

1980-1981 HEATING SEASON

(Al) values in million BTU, unless otherwise indicated)

\begin{tabular}{|c|c|c|c|c|c|c|c|}
\hline MONTH & $\begin{array}{c}\text { ENERGY TO } \\
\text { STORACE } \\
\end{array}$ & $\begin{array}{c}\text { EMERGY FROM } \\
\text { STORAGE }\end{array}$ & $\begin{array}{l}\text { CHAMGE IN } \\
\text { STORED EMEAGY } \\
\end{array}$ & $\begin{array}{c}\text { STORAGE } \\
\text { EFFICIEMCY } \\
(\xi) \\
\end{array}$ & $\begin{array}{c}\text { AVERAGE } \\
\text { STORAGE } \\
\text { TERPRATURE } \\
\text { (OE) } \\
\end{array}$ & $\begin{array}{l}\text { EFFECTIVE } \\
\text { MEAT LOS } \\
\text { COEFFICIENT } \\
\text { (BTU/hR-OF) } \\
\end{array}$ & $\begin{array}{l}\text { LOSS FROM } \\
\text { STORAGE }\end{array}$ \\
\hline OCT & 35.2 & 19.4 & 2.41 & 62 & 170 & 0.13 & 13.4 \\
\hline nov & 105 & 107 & -12.5 & 90 & 152 & 0.13 & 10.8 \\
\hline DEC & 55.2 & 55.0 & -3.01 & 94 & 86 & 0.10 & 3.21 \\
\hline JAN & 152 & 141 & 3.48 & 97 & 116 & 0.06 & 7.03 \\
\hline FEB & 109. & 102 & -0.15 & 94 & 123 & 0.14 & 7.02 \\
\hline MAR & • & - & 7.52 & - & * & $\star$ & " \\
\hline APR & 6.05 & 4.59 & -7.22 & -44 & 136 & 0.12 & 8.68 \\
\hline TOTAL & 462 & 429 & -9.47 & $\cdot$ & - & - & 50.1 \\
\hline AVERACE & 77.0 & 71.5 & -1.35 & 91 & 131 & 0.12 & 8.35 \\
\hline
\end{tabular}

- Denotes unavoilable data. 
The storage losses, STLOSS, were calculated from the measured temperature decay after April 19, 1980, when no energy was put into or taken out of the tank. The storage temperature was $185^{\circ} \mathrm{F}$ on April 19, 1980, and slowly declined over a period of months. (On May 31, 1980, storage temperature was 1160 F.) The temperature of storage should decline expotentionally, according to:

where:

$$
\left.e^{(-A \times T i m e) / R} \times C_{p} \times \text { Mass }\right)
$$

$$
\begin{aligned}
A= & \text { Area of tank }=1,314 \text { square feet } \\
R= & \text { R-value of insulation } \\
C_{p}= & \text { Specific heat of water }=1 \\
\text { Mass }= & \text { Mass of water in storage }=20,000 \times 8.335= \\
& 166,70 n \text { ihr. }
\end{aligned}
$$

An R-value of 7.6 gave the best fit to the decay curve. This value is considerably lower than the R-value of 20 which should nominally be available from six inches of fiberglass.

Using the R-value of 7.6 , the storage loss was calculated from:

$$
S T L O S S=A \times(T S T-T B) / R
$$

where: $\quad T S T=$ Measured storage temperature

$$
\begin{aligned}
T B= & \text { Temperature of building. (The temperature of the } \\
& \text { storage tank room is } 50 \mathrm{~F} \text { to loof cooler than the } \\
& \text { temperature measured during the winter.) }
\end{aligned}
$$

The energy from storage was then calculated from this empirical storage loss, and the measured values of the solar energy entering into and departing from the storage tank.

The plot of storage temperatures for January 29, 1981, Figure 20, shows that there was little stratification in the tank. The load pump runs throughout the heating system, keeping the tank well mixed. 


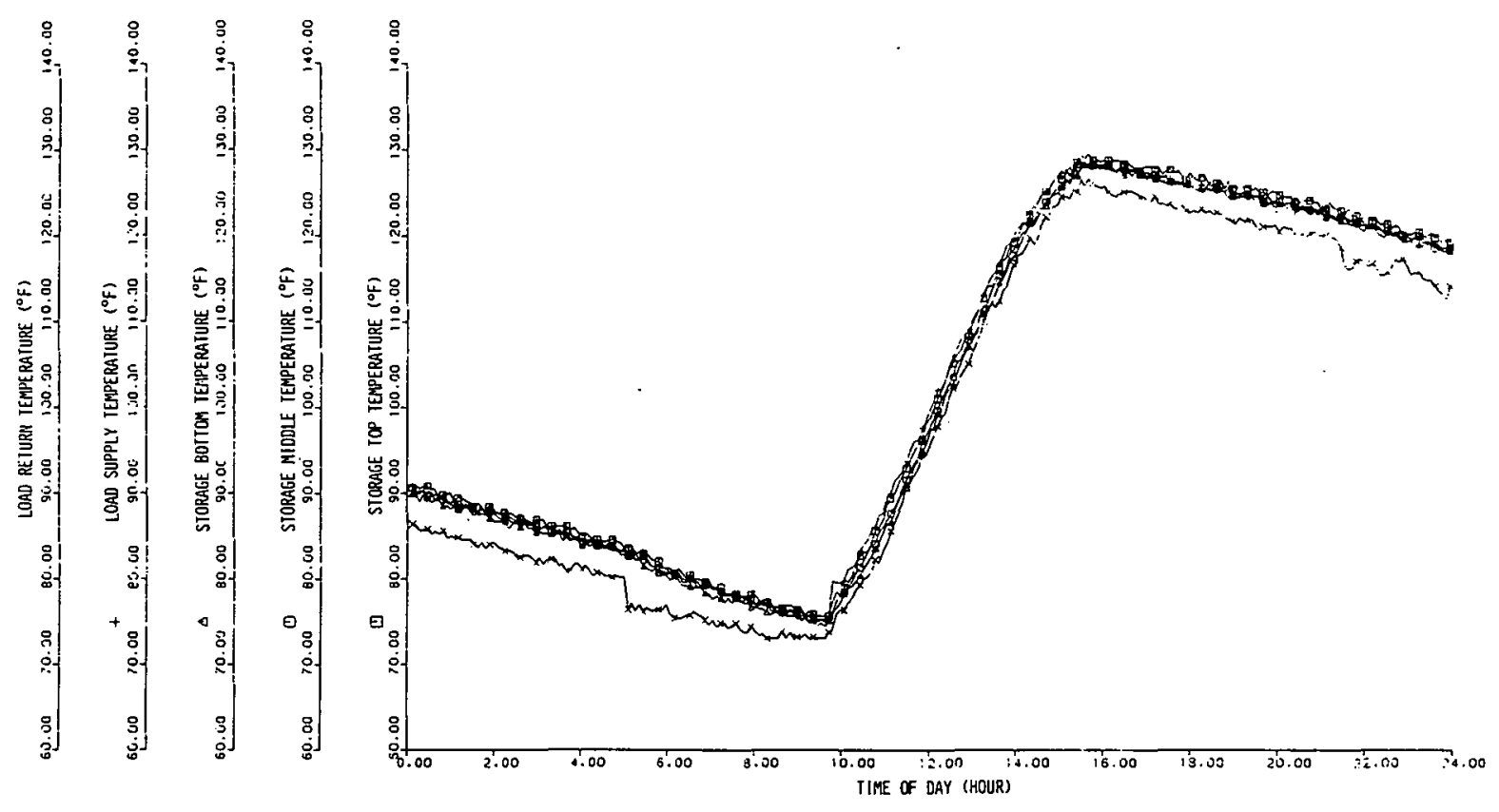

Figure 20. Plot of Storage Temperatures

Telex Communications

January 29,1981

\section{3 .3 Heating}

The space heating performance for the Telex Communications solar system is presented in Table 26 for the 1979-1980 heating season, and in Tables $27 \mathrm{a}$ and $27 \mathrm{~b}$ for the 1980-198i heating season. The performance is consistent in the amount of solar energy used from season to season, and the solar fraction is about equal to the design value (and better than the f-chart prediction). The solar fraction undoubtedly would have been higher in the second season if March were included, but the data collection system was not functiulling durlng March 1981 .

The value of solar energy used for space heating is actually the amount of solar energy that goes into the storage tank from the collectors plus (minus) depletion. of (addition to) stored energy. Once in the tank, all the energy will heat the building. As explained in the storage performance section $(10.3 .2)$, the measured energy going to the space heating load was larger than the energy into storage, so there is no reason to suspect large pipe losses in the space heating distribution system. The plot of heating load and storage temperatures (Figure 20) shows the small temperature difference between the load supply and return. The supply temperature is equal to the well-mixed storage tank temperature, with the return $3 \circ \mathrm{F}$ or $40 \mathrm{~F}$ lower. Note the sharp drop in the return temperature at 5:00 a.m. when the heat is turned up. The solar energy appears to be utilized well at storage temperatures as low as $76^{\circ} \mathrm{F}$. 
Table 26. SPACE HEATING SUBSYSTEM PERFORMANCE

TELEX COMMUNICATIONS

1979-1980 HEATING SEASON

(All values in million BTU, unless otherwise indicated)

\begin{tabular}{|c|c|c|c|c|c|c|c|c|}
\hline \multirow[b]{2}{*}{ MONTM } & \multirow[b]{2}{*}{$\begin{array}{l}\text { SPACE } \\
\text { HEATI NG } \\
\text { LOAD }\end{array}$} & \multicolumn{5}{|c|}{ EHERGY COHSUREO } & \multirow[b]{2}{*}{$\begin{array}{c}\text { SOLAR } \\
\text { FRACTION } \\
(\Phi) \\
\end{array}$} & \multirow[b]{2}{*}{$\begin{array}{l}\text { BUILDING } \\
\text { TENPERATURE } \\
\text { (OF) }\end{array}$} \\
\hline & & SOLAR & $\begin{array}{l}\text { AUX I LIARY } \\
\text { THERMAL }\end{array}$ & $\begin{array}{l}\text { AUXILIAAY } \\
\text { ELECTRICAL }\end{array}$ & $\begin{array}{l}\text { SOLAR } \\
\text { OPERATING } \\
\text { ENERGY }\end{array}$ & $\begin{array}{l}\text { POTAL } \\
\text { OPERATING } \\
\text { ENEREY }\end{array}$ & & \\
\hline nov & 85.6 & 77.7 & 0.19 & 0.19 & 5.70 & 7.49 & 91 & 71 \\
\hline DEC & 122 & 103 & 2.98 & 2.98 & 9.25 & 16.0 & 84 & 69 \\
\hline JAN & 144 & 69.6 & 55.0 & 55.0 & 9.73 & 18.7 & 48 & 69 \\
\hline FEB & 154 & 102 & 37.5 & 37.5 & 8.38 & 13.7 & 66 & 68 \\
\hline$A P R$ & 61.3 & 39,7 & 0.95 & n 95 & 4.60 & 6.24 & 88 & 73 \\
\hline TOTOL & 220 & 911 & 109 & 109 & 46.7 & 77.4 & & \\
\hline AVERAGE & 120 & 38.8 & 18.1 & 18.1 & 7.79 & 12.9 & 74 & 70 \\
\hline
\end{tabular}

Table 27a. SPACE HEATING SUBSYSTEM PERFORMANCE

TFLEX COMMUNICATIONS

1980-1981 HEATING SEASON

(All values in million BTU, unless otherwise indicated)

\begin{tabular}{|c|c|c|c|c|c|c|c|}
\hline MONTH & $\begin{array}{c}\text { SPACE } \\
\text { MEATING } \\
\text { LOAD } \\
\end{array}$ & $\begin{array}{l}\text { CONTROLLED } \\
\text { DELIVEREO } \\
\text { EAERGY }\end{array}$ & $\begin{array}{l}\text { TOTAL SOLAR } \\
\text { EMEACY USED } \\
\end{array}$ & $\begin{array}{c}\text { TOTAL } \\
\text { AUXILIAAY } \\
\text { THERALL USED } \\
\end{array}$ & $\begin{array}{l}\text { SOLAR } \\
\text { FAACTIOM } \\
\text { OF LOAD } \\
\text { (I) }\end{array}$ & $\begin{array}{c}\text { OUILOIAE } \\
\text { TEMPERATURE } \\
\text { JOF) } \\
\end{array}$ & $\begin{array}{c}\text { AMBIENT } \\
\text { TEMPERATUE } \\
\text { (OF) } \\
\end{array}$ \\
\hline OCT & 33.8 & 19.4 & 32.8 & 0.01 & 97 & 74 & 49 \\
\hline nov & 127 & 107 & 118 & 0.40 & 93 & 73 & 38 \\
\hline ott & 141 & 111 & 90.8 & 73.1 & 40 & 66 & 29 \\
\hline JAM & 259 & 239 & 148 & 95.9 & 57 & 68 & 19 \\
\hline$f \in B$ & 233 & 214 & 109 & 113 & 4) & 03 & al \\
\hline MAR & $*$ & " & - & " & * & " & * \\
\hline$A P R$ & .13 .8 & 4.75 & 13.3 & 0.16 & 96 & 7) & 50 \\
\hline TOTAL & 813 & 112 & $4 i y$ & 281 & . & • & \\
\hline AVERAGE & 135 & 119 & 79.8 & 46.9 & 59 & 71 & 30 \\
\hline
\end{tabular}

- Denotes unavailablo data. 
Table 27b. SPACE HEATING SUBSYSTEM PERFORMANCE

TELEX COMMUNICATIONS

1980-1981 HEATING SEASON

(Continued)

(All values in million BTU, unless otherwise indicated)

\begin{tabular}{|c|c|c|c|c|c|c|c|}
\hline MONTH & $\begin{array}{c}\text { SPACE } \\
\text { MEATING } \\
\text { LOAD } \\
\end{array}$ & $\begin{array}{l}\text { MEASUREO } \\
\text { SOLAR } \\
\text { ENERGY USED } \\
\end{array}$ & $\begin{array}{l}\text { SOLAR } \\
\text { ENERGY } \\
\text { COSES } \\
\text { TO LOAO } \\
\end{array}$ & $\begin{array}{l}\text { TOTAL } \\
\text { OPERTING } \\
\text { ENERGY } \\
\end{array}$ & $\begin{array}{l}\text { SOLAR } \\
\text { SPECIFIC } \\
\text { OPERAING } \\
\text { ENERGY } \\
\end{array}$ & $\begin{array}{l}\text { AUXILIARY } \\
\text { ELECTRICAL } \\
\text { FUEL } \\
\end{array}$ & $\begin{array}{l}\text { HEATING } \\
\text { OEGREE } \\
\text { OAYS } \\
\end{array}$ \\
\hline OCT & 33.8 & 19.4 & 13.4 & 0.79 & 0.72 & 0.01 & 485 \\
\hline NOV & 127 & 107 & 10.8 & 8.08 & 6.27 & 0.40 & 735 \\
\hline DEC & 147 & 55.0 & 3.21 & 16.2 & 9.55 & 72.1 & 1.391 \\
\hline JAN & 259 & 141 & 7.03 & 14.1 & 9.24 & 95.9 & 1.425 \\
\hline$F E B$ & 233 & 102 & 7.02 & 11.3 & 7.80 & 113 & 1.167 \\
\hline MAR & . & . & - & - & - & * & " \\
\hline APR & 13.8 & 4.59 & 8.68 & 0.15 & 0.15 & 0.16 & 441 \\
\hline TOTAL & 813 & 429 & 50.1 & 50.6 & 33.7 & 281 & 5.644 \\
\hline AVE AAGE & 135 & 71.5 & 8.35 & 8.44 & 5.62 & 46.9 & 941 \\
\hline
\end{tabular}

* Denozes unavailaole daca.

\section{3 .4 Parasitics}

Measured values of the Telex Communications operating energy for the 1979-1980 and 1980-1981 heating seasons are presented in Tables 28 and 29. The solar system used $66.6 \mathrm{million}$ BTU of operating energy in the period November 1979 through April 1980 , and $47.4 \mathrm{milli}$ ion BTU in the period October 1980 through February 1981, plus April 1981 .

The components which use operating energy are:

$$
\begin{array}{r}
\text { Collector rump ( } \begin{array}{r}
\text { (.5-hp Bell \& Gossett } \\
\text { centrifugal pump) }
\end{array} \\
\text { Sump Pump (2-hp Aurora sump pump) }
\end{array}
$$

Heating Load Pump (5-hp Bell \& Gossett centrifugal pump)

$6.7 \mathrm{kw}$

Distribution Blowers in Air-Handler Units 5,6 , and 7

$3.7 \mathrm{kw}$

$5.4 \mathrm{kw}$ each

Solar Heater with $5-k w$ blower

The three pairs of air handler units known as 1-2, 3-4, and 8-9 run year-round for ventilation, so they are not included. They are each $10.8 \mathrm{kw}$. 
Table 28. SOLAR OPERATING ENERGY

TELEX COMMUNICATIONS

1979-1980 HEATING SEASON

(All values in million BTU)

\begin{tabular}{lccc} 
MONTH & $\begin{array}{c}\text { ECSS } \\
\text { OPERATING ENERGY } \\
(\text { SOLAR-UNIQUE) }\end{array}$ & $\begin{array}{c}\text { SHS } \\
\text { OPERATING ENERGY } \\
\text { (SOLAR) }\end{array}$ & $\begin{array}{c}\text { TOTAL SOLAR } \\
\text { OPERATING ENERGY }\end{array}$ \\
\hline NOV & 1.48 & 5.70 & 7.18 \\
DEC & 3.98 & 9.25 & 13.2 \\
JAN & 3.28 & 9.73 & 13.0 \\
FEB & 3.89 & 8.38 & 12.3 \\
MAR & 4.34 & 9.08 & 13.4 \\
APR & 2.93 & 4.60 & 7.53 \\
\hline TOTAL & 19.9 & 46.7 & 66.6 \\
AVERAGE & 3.32 & 7.79 & 11.1
\end{tabular}

Table 29. SOLAR OPERATING ENERGY

TELEX COMMUNI LATI UNS

IY8U-IY8I HEATING SEASON

(All values in million BTU)

\begin{tabular}{lccc} 
MONTH & $\begin{array}{c}\text { ECSS } \\
\text { OPERATING ENERGY } \\
\text { (SOLAR-UNIQUE) }\end{array}$ & $\begin{array}{c}\text { SHS } \\
\text { OPERATING ENERGY } \\
\text { (SOLAR) }\end{array}$ & $\begin{array}{c}\text { TOTAL SOLAR } \\
\text { OPERATING ENERGY }\end{array}$ \\
\hline OCT & 0.97 & 0.72 & 1.69 \\
NOV & 1.33 & 6.27 & 7.60 \\
OEC & 2.30 & 9.55 & 11.9 \\
JAN & 3.28 & 9.24 & 12.5 \\
FEB & 1.56 & 7.80 & 12.4 \\
MAR & $*$ & $*$ & $*$ \\
APR & 1.19 & 0.15 & 1.34 \\
\hline TOTAL & 13.6 & 33.7 & 47.4 \\
AVERAGE & 2.27 & 5.62 & 7.89 \\
\# DenOtes unavailable data. & &
\end{tabular}


The solar energy Coefficient of Performance (COP) is presented in Tables 30 and 31 . The COP provides a numerical value for the relationship of solar energy used or collected and the energy required to deliver or collect it (higher cop equals greater efficiency). The solar COP for the two heating seasons combined was 8.86: The collection subsystem COP was high in both Novembers because the collector pump was throttled down, pumping at a reduced flow rate and consuming less power per hour of collection.

Table 30. COEFFICIENT OF PERFORMANCE

TELEX COMMUNICATI ONS

1979-1980 HEATING SEASON

\begin{tabular}{lccc} 
MONTH & $\begin{array}{c}\text { SOLAR } \\
\text { ENERGY SYSTEM }\end{array}$ & $\begin{array}{c}\text { COLLECTION } \\
\text { SUBSYSTEM }\end{array}$ & $\begin{array}{c}\text { SPACE HEATING } \\
\text { SOLAR }\end{array}$ \\
\hline NOV & 10.8 & 54.6 & 13.6 \\
DEC & 7.76 & 29.8 & 11.1 \\
JAN & 5.35 & 26.8 & 7.15 \\
FEB & 8.30 & 31.2 & 12.2 \\
MAR & 9.32 & 35.7 & 13.8 \\
APR & 7.12 & 26.1 & 11.7 \\
\hline WEIGHTED & 7.96 & 32.2 & 11.4 \\
AVERAGE & & & .4
\end{tabular}

Table 31. COEFFICIENT OF PERFORMANCE

TELEX COMMUNICATIONS

1980-1981 HEATING SEASON

\begin{tabular}{lccc} 
MONTH & $\begin{array}{c}\text { SOLAR } \\
\text { ENERGY SYSTEM }\end{array}$ & $\begin{array}{c}\text { COLLECTION } \\
\text { SUBSYSTEM }\end{array}$ & $\begin{array}{c}\text { SPACE HEATING } \\
\text { SOLAR }\end{array}$ \\
\hline OCT & 19.4 & 38.2 & 26.9 \\
NOV & 15.5 & 83.4 & 17.1 \\
OEC & 4.9 & 24.5 & 5.8 \\
JAN & 11.8 & 46.3 & 15.3 \\
FEB & 8.8 & 23.8 & 13.0 \\
MAR & $*$ & $*$ & $*$ \\
APR & 9.9 & 5.5 & 30.6 \\
\hline WEIGHTED & 10.1 & 34.6 & 12.7 \\
AVERAGE & & &
\end{tabular}




\subsection{ENERGY SAVINGS}

Energy savings for the Telex Communications solar system are presented in Tables 32 and 33: The total for the two heating seasons was $895 \mathrm{million}$ BTU. Additional savings were realized, but not measured because of data system problems in october 1979 and March 1981. If values for October 1980 and March 1980, respectively, are substituted, the projected savings would be $1,040 \mathrm{mil} 1 \mathrm{i}$ on BTU, or $519 \mathrm{mi} l 1$ ion BTU/season. This is equivalent to $152,100 \mathrm{kwh}$ of electricity saved per season. This is equivalent to $\$ 7,605$ saved at the 1980 rate of $\$ 0.05$ per kwh. Built in 1977 at a cost of $\$ 460,000$, the solar system will not pay for itself quickly.

Table 32. ENERGY SAVINGS

TELEX COMMUNI CATIONS

1979-1980 HEATING SEASON

(All valuas in million BTII)

\begin{tabular}{lcccc} 
MONTH & $\begin{array}{c}\text { SOLAR } \\
\text { ENERGY USED }\end{array}$ & $\begin{array}{c}\text { SPACE HEATIMG } \\
\text { ELECTRICAL }\end{array}$ & $\begin{array}{c}\text { ECSS } \\
\text { OPERATIMG } \\
\text { ENERGY }\end{array}$ & $\begin{array}{c}\text { NET ENERGY SAVINGS } \\
\text { ELECTRICAL }\end{array}$ \\
\hline NOV & 77.7 & 72.0 & 1.48 & 70.6 \\
DEC & 103 & 93.4 & 3.98 & 89.4 \\
JAN & 69.6 & 59.8 & 3.28 & 56.6 \\
FEB & 102 & 93.5 & 3.89 & 89.6 \\
MAR & 125 & 116 & 4.34 & 112 \\
APR & 53.7 & 49.1 & 2.93 & 46.1 \\
\hline TOTAL & 531 & 484 & 19.9 & 464 \\
AVERAGE & 88.4 & 80.7 & 3.32 & 77.3
\end{tabular}

Table 33. ENERGY SAVINGS

TELEX COMMUNICATIONS

1980-1981 HEATING SEASON

(A) l volues in million BTU)

\begin{tabular}{|c|c|c|c|c|}
\hline YOHTH & $\begin{array}{c}\text { SOLAR } \\
\text { EMEROY USLO }\end{array}$ & $\begin{array}{l}\text { SPACE HEATING } \\
\text { ELCCTNICAL }\end{array}$ & $\begin{array}{c}\text { ECSS } \\
\text { OPERATING } \\
\text { ENERCY } \\
\end{array}$ & $\begin{array}{c}\text { NET ENERGY SAVINGS } \\
\text { ELECTRICAL } \\
\end{array}$ \\
\hline OCT & 32.8 & 32.1 & 0.97 & 31.1 \\
\hline NOV & 118 & 111 & 1.33 & 110 \\
\hline DEC & 58.2 & 48.6 & 2.30 & 46.3 \\
\hline JAN & 148 & 139 & 3.28 & 136 \\
\hline FEB & 109 & 101 & 4.56 & 96.3 \\
\hline MAR & * & * & * & * \\
\hline APR & 13.3 & 13.1 & 1.19 & 11.9 \\
\hline TOTAL & 479 & 445 & 13.6 & 431 \\
\hline AVERAGE & 79.8 & 74.2 & 2.27 & 71.9 \\
\hline
\end{tabular}




\subsection{ENVIRONMENTAL CONDITIONS}

Weather conditions for the winters of 1978-1979, 1979-1980, and 1980-1981 are presented in Tables 34, 35, and 36. The insolation values are measured in the plane of the collector, which faces due south with a tilt of 58.5 degrees. The long-term insolation values are modeled to represent insolation on a tilted surface by a TRNSYS-type radiation processor, from SOLMET long-term horizontal values. Long-term temperatures and horizontal insolation values are based on the historical record for Rochester, Minnesota, which is about 75 miles east and 25 miles north of Blue Earth. Insolation was close to, but somewhat above, the long-term average in all three seasons. One would expect the insolation values in the winter to be higher than the long-term average, due to reflection from the persistent snow cover, which would have more effect on our measurements at a 58.5 degree tilt than on the long-term horizontal values. The long-term program uses a $20 \%$ enhancement for ground reflection. The winter of 1978-1979 was especially bitter, with far below normal temperatures. Both 1979-1980 and 1980-1981 were warmer than the long-term average.

Table 34. WEATHER CONDITIONS

TELEX COMMUN I CATI ONS

1978-1979 HEATING SEASON

\begin{tabular}{|c|c|c|c|c|c|c|c|}
\hline \multirow[b]{2}{*}{ MONTH } & \multicolumn{2}{|c|}{$\begin{array}{l}\text { DAILY INCIOENT SOLAR } \\
\text { EAERGY PRER UNIT AARA } \\
\text { (BTU/FT OOAY) }\end{array}$} & \multicolumn{2}{|c|}{ AMBIEAT TEMPERATURE (OF) } & \multicolumn{2}{|c|}{ HEATING DEGREE-DAYS } & \multirow[b]{2}{*}{$\frac{\text { WIND SPEEO (MPH) }}{\text { REASURED }}$} \\
\hline & MEASUREO & $\begin{array}{l}\text {-OAY) } \\
\text { LONG-TERA } \\
\text { AVERAGE }\end{array}$ & MEASUREO & $\begin{array}{l}\text { LATURE }(\text { DF } \\
\text { LOMG-TEAA } \\
\text { AVERAGE }\end{array}$ & MEASURED & $\begin{array}{c}\text { PREE- DAVS } \\
\text { LONG-TERA } \\
\text { AVERAGE }\end{array}$ & \\
\hline OCT & 1.201 & $1.28 y$ & 48 & 50 & 527 & 485 & . \\
\hline nov & 766 & 889 & 30 & 33 & 1.050 & 972 & , \\
\hline Dec & 943 & 734 & 13 & 19 & 1.612 & 1.429 & 8 \\
\hline JAN & 1.159 & 938 & 0 & 13 & 2,015 & 1.615 & 8 \\
\hline FEB & 1.562 & 1.207 & 7 & 17 & 1,624 & 1.347 & 1 \\
\hline MAR & 1.084 & 1.331 & 26 & 28 & 1.209 & 1.153 & 10 \\
\hline TOTAL & . & - & - & - & 8.037 & 7.001 & - \\
\hline AVE nAGE & 1.180 & 1.009 & $\therefore 1$ & « & 1.140 & 1,167 & y \\
\hline
\end{tabular}

- Denoces unavailade daca. 
Table 35. WEATHER CONDITIONS

TELEX COMMUNI CATI ONS

1979-1980 HEATING SEASON

\begin{tabular}{|c|c|c|c|c|c|c|c|}
\hline \multirow[b]{2}{*}{ NOMTH } & \multicolumn{2}{|c|}{$\begin{array}{c}\text { OAILY INCIDENT SOLAR } \\
\text { ENERCY PER UNIT AREA } \\
\text { BTUFT OAYT } \\
\end{array}$} & \multicolumn{2}{|c|}{ AKBIENT TEMPERATURE (OF) } & \multicolumn{2}{|c|}{ HEATING OEGREE-DAYS } & \multirow[b]{2}{*}{$\frac{\text { WIND SPEED (MPH) }}{\text { REASURED }}$} \\
\hline & MEASUREO & $\begin{array}{l}\text { LONG-TERA } \\
\text { AVERAGE }\end{array}$ & MEASURED & $\begin{array}{l}\text { CONG-TERA } \\
\text { AVERAGE }\end{array}$ & MEASUREO & $\begin{array}{l}\text { LONG-TERA } \\
\text { AVERAGE }\end{array}$ & \\
\hline nov & 927 & 899 & 32 & 33 & 992 & 972 & 8 \\
\hline DEC & 848 & 734 & 26 & 19 & 1.219 & 1,429 & 7 \\
\hline JAN & 746 & 938 & 16 & 13 & 1,505 & 1.615 & 9 \\
\hline FEB & 1,223 & 1.207 & 16 & 17 & 1,427 & 1,347 & 7 \\
\hline MAR & 1,275 & 1,331 & 28 & 28 & 1.138 & 1.153 & 9 \\
\hline APR & 1.478 & 1.335 & 48 & 45 & 531 & 615 & 8 \\
\hline TOTAL & - & - & - & - & 6.812 & 7.131 & - \\
\hline AVERACE & 1.083 & 1.072 & 28 & 26 & 1.135 & 1.189 & 8 \\
\hline
\end{tabular}

Table 36. WEATHER CONDITIONS

TELEX COMMUNICATI ONS

1980-1981 HEATING SEASON

\begin{tabular}{|c|c|c|c|c|c|c|c|}
\hline \multirow[b]{2}{*}{ NONTM } & \multicolumn{2}{|c|}{$\begin{array}{l}\text { DAILY IHGIOCNT SOLAN } \\
\text { ENERGY DER UHIT AREA } \\
\text { (OTU/FT2.DAY) } \\
\end{array}$} & \multicolumn{2}{|c|}{ AMOIENT TEMPEAATUAE (OF) } & \multicolumn{2}{|c|}{ HEATIHE DECREE-DAYS } & \multirow{2}{*}{$\begin{array}{c}\text { WIND SPEED } \\
\text { MEASUACD } \\
\text { (MPK) }\end{array}$} \\
\hline & ACASUACO & $\begin{array}{l}\text { CONG-TERH } \\
\text { AVEAAQE }\end{array}$ & NEASUREU & $\begin{array}{l}\text { LOMG-TEAN } \\
\text { AVERAGE }\end{array}$ & NEASUREO & $\begin{array}{l}\text { LONG-TEAA } \\
\text { AVERACE } \\
\end{array}$ & \\
\hline OCT & 1.380 & 1,289 & 49 & 50 & 485 & 485 & 7 \\
\hline Nov & 1.311 & 889 & 40 & 33 & 735 & 972 & 5 \\
\hline OEC & 627 & 734 & 20 & 19 & 1.391 & 1,429 & 7 \\
\hline sAM & 1.325 & 938 & 19 & 13 & 1.425 & 1.615 & 7 \\
\hline PCa & 1.252 & 1.207 & $2 i$ & 17 & 1.167 & $1: 347$ & 10 \\
\hline MAR & * & * & $*$ & $\star$ & * & 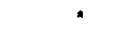 & * \\
\hline$A P R$ & 1.175 & 1.335 & 50 & 45 & 441 & 615 & 9 \\
\hline TOTAL & - & - & - & - & 5.644 & 6.463 & $\cdot$ \\
\hline AVERAGE & 1.178 & 1.065 & 33 & 30 & 941 & 1.077 & 8 \\
\hline
\end{tabular}

- Uenozes unduaitable data. 


\author{
SECTION II \\ OPERATIONAL HISTORY
}

\title{
11.1 SYSTEM
}

System construction began in August 1977, and was substantially complete by December 1977. The system startup problems as of March 1978 are listed in Section 9.3. The system has a space heating load only, so it was not used in the summer of 1978. The system was operated a short time each day on September 25-28, 1978, in preparation for the coming heating season. The storage tank temperature was raised from $81^{\circ} \mathrm{F}$ to $152^{\circ} \mathrm{F}$. The solar heating system began continuous operation on october 1, 1978, and energy collection commenced on october 5, 1978. From this time, through the summer of 1984, the only major operational problems were a freezeup in December 1978, and problems with slipping hose connections that were substantially solved in the summer and early fall of 1979 .

Over the weekend of December 2 and 3, 1978, a freeze-up occurred which was discovered on Monday, December 4. The freeze-up was confined to the lower headers of Rows 7 and 10 (Row 1 is the southernmost row). There was no evidence of freezing in any of the other eight rows. The computer listing of the system performance data showed no unusual behavior other than some cycling of the collector pump, which was to be expected because of the marginal insolation conditions which prevailed over that weekend.

The Telex Communications system relies on the draining of the collectors for freeze protection. To relieve the vacuum caused by the draining water, air vents and vacuum breakers were installed at the outlet of each row. They were specified to be heat-taped and insulated. A close inspection of the air vents and vacuum breakers showed that under near-zero temperatures the heat tape was not keeping these devices above freezing. This problem was due partly to the lack of tight contact between the heat tape and the bodies of the vents and breakers and partly to the lack of insulation around the vent holes.

It was not clear, though, how nonoperative air vents and vacuum breakers could have led to the freezing of only two rows out of 10. The entire system would drain if any of the 10 sets of air vents and vacuum breakers operate, because all the rows are connected in parallel. The actual draindown time was established by test at less that 10 minutes. It was also found that sections of the pipe and valves that contained ice due to incomplete draining could be cleared in a few minutes after the system pump started.

While the freeze problem was being investigated, it was decided to run the system under manual control to eliminate short cycling. The system (eight rows) was then operated through the month of 
December only on clear days. On January 1, 1979, the system was started up and it was noticed that the absorber plate temperature on Row 5 remained high. Upon investigation, it was found that the bottom manifold of this row was frozen. Examination of the previous day on which the system operated revealed no abnormalities. At a meeting in January it was decided to install standpipe vents at each row as well as at the north and south ends of the return header. These standpipes were to be heat-taped and insulated. Also, piping on the supply side was changed to steeper slope. This work was carried out in February and the system was placed into operation with seven rows on February 25 with no further freeze problems.

The problem with the slipping hoses is discussed in Section 11.2.3.

\subsection{COLLECTION SUBSYSTEM OPERATI ONAL HISTORY}

\section{2 .1 Operation}

The Telex Communications collector array has operated efficiently throughout its history. Performance monitoring began on April 7 , 1978. In April 1978, the overall collector efficiency was $42 \%$ for the month. Efficiency was good throughout the monitoring period. Overall collector efficiency was $27 \%$ in February 1981 , with $44 \%$ operational collector efficiency. This was the last full month of monitored operation. Telex Communications says the collectors have produced the continued expected quantity of heat through the subsequent heating seasons.

Early in the history of the Telex Communications solar system, in July 1978, there was some concern that the collector pump might accidentally turn on at night, which would be disastrous in the winter. Johnson Controls quoted a price of $\$ 1,063$ for a photocell and aquastat to prevent this, and Telex Communications decided it was not worth the cost. On october 20, 1978, the collector control failed, and the collector pump ran all night. It was not cold enough to damage the array. Johnson Controls found the problem to be a bad collector control temperature sensor. Telex Communications requested a backup safety to prevent a recurrence. The problem has not recurred.

The operation of the collection subsystem on a typical clear day was described in detail in Section 10.3.1, Collection subsystem. It was pointed out in that section that the collector pump runs for a smaller fraction of the time when the sun is shining than in most of the NSDN-monitored solar systems. To illustrate, the operation of the solar system on a partly cloudy day, January 23,1981 , i.s described.

January 23 was a mild day for January, with an overnight low of $18^{\circ} \mathrm{F}$ and a daytime high temperature of $54^{\circ} \mathrm{F}$ at $2: 25 \mathrm{p.m}$. The collector pump first turned on at $9: 38$ a.m., with an absorber plate temperature of $207^{\circ} \mathrm{F}$, storage temperature of $128^{\circ} \mathrm{F}$, and insolation 
of 220 BTU/ft2-hr. At $9: 58$ a.m., insolation dropped to 115 BTU/ $\mathrm{ft} 2-\mathrm{hr}$, the absorber plate temperature declined to $130^{\circ} \mathrm{F}$, the storage temperature was still $128^{\circ} \mathrm{F}$, and the collector shut off. This seems reasonable for the collector to shut off, with the absorber plate within $2^{\circ} \mathrm{F}$ of storage, but, on the clear day, January 29 , 1981 (see Figure 18 on Page 58), the collector did not turn on unti l the absorber plate was more than $50^{\circ} \mathrm{F}$ warmer than storage. The collector pump came on again at 10:15 a.m., when the storage temperature was $129^{\circ} \mathrm{F}$, the absorber plate temperature was $158^{\circ} \mathrm{F}$, and insolation was $184 \mathrm{BTU} / \mathrm{ft} 2-\mathrm{hr}$. The pump cycled on and off more than a dozen times on that day. Some of the cycling appears to be unnecessary; for example, at $2: 21 \mathrm{p} . \mathrm{m}$., the pump switched off for four minutes when insolation fell to 190 BTU/ft2-hr, the absorber plate temperature went to $153^{\circ} \mathrm{F}$, while storage was at a temperature of $146^{\circ} \mathrm{F}$. There was still a $+60^{\circ} \mathrm{F}$ temperature rise across the collectors when the pump shut off. For the day as a whole, there were $16.5 \mathrm{milli}$ on BTU of incident solar energy, but the collector pump ran while only $9.1 \mathrm{milli}$ on BTU were incident.. of this, $3.8 \mathrm{million}$ BTU were collected.

The collector operation is characterized by very efficient collection, but a tendency to be oversensitive to clouds, starting later and shutting off sooner than necessary for optimum efficiency. The designers wanted to err on the side of safety, because a freeze-up could happen quickly if the pump came on when insolation was too low, but some efficiency was lost as a result. The loss in efficiency is not large, though, considering the system produces more solar energy than f-chart predicts.

The flow equalization tubes in the collector manifolds were removed in July 1979, because Telex Communications feared the tubes had or might contribute to freezing because of the flow restriction. Theoretically, this should imbalance the collector flow, and lead to low flow in the middle of the rows, but no adverse effect upon performance has been detected. Thermography did not reveal any flow imbalance, either.

\subsubsection{Collector Controls}

The collector pump is set to turn on when the absorber plate temperature exceeds the storage temperature by $25^{\circ} \mathrm{F}$, and to turn off when this difference falls to $20 \mathrm{~F}$. This setting was apparently maintained throughout the history of the Telex Communications solar system. For details of the operation of the collectors under the control settings, see the previous section, 11.2 .1 , and also section 10.3 .1 .

On October 20, 1978, approximately five million BTU of energy were rejected by the collectors when the collector pump ran all night. After this problem was discovered, the collector pump was operated manually. The problem was a bad collector control sensor: which was replaced on November 1, 1978, and automatic operation was restored. 
From the beginning of the heating season in 0ctober 1980 until November 19, 1980, the collector pump was operated manually, and with a timer, because the controller had failed. It was repaired November 19,1980 .

\subsubsection{Collector Reliability and Maintainability}

The collector freeze-up in December 1978 was discussed in Section 11.1. The only other problem concerned the hoses joining the collectors. The collectors are internally manifolded with $2 \frac{1}{2}-i n c h$ headers. Connections from collector to collector were initially made with a reinforced silicone rubber hose. Because of the length of the row (144 feet) and the large temperature range to which the manifolds would be exposed, there could be changes in the length of the row of up to \pm two inches due to therma! expansion and contractlull. I $l$ was anticipated thet thc silicone hoses would be capable of absorbing this movement. In the actual installation, however, it was found that the axial forces could be transmitted down the manifolds to the hose that was clamped with the weakest pressure. This hose would then slip on the manifold, eventually resulting in a leak.

The solution was the change all the hoses to a different type. The new hose has a single "hump" at its midsection which allows it to act as an expansion compensator. The new hump hose is also constructed of silicone rubber and is capable of withstanding the $350^{\circ} \mathrm{F}-400^{\circ} \mathrm{F}$ stagnation temperatures that the absorber reaches. As a further precaution against leaks, the hoses were bonded to the copper manifolds using a primer and silicone adhesive. An unlined hose clamp was also used. The installation of the hoses took place in the summer and early fall of 1979.

After this repair, the hoses still sip occasionally, but it is not a major problem. The hose clamps must be retightened several times a year. This job takes about two hours.

\section{2 .4 Maintenance and Repairs - Collector}

There is no regular maintenance required for the solar collectors. During extremely cold weather, the standpipe openings must be inspected for ice buildup. Any ice buildup must be removed. Repairs were discussed in Sections 11.1 and 11.2 .3 .

\subsection{STORAGE SUBSYSTEM OPERATIONAL HISTORY}

\section{3 .1 Operation}

Storage water (which is also collector water and load water) is treated automatically by a Culligan Mark 512 Automatic Water conditioner. The treatment includes a rust inhibitor, $c-70$, 
composed mostly of nitrite, borate, and MBT. The dosage used is $1,500 \mathrm{ppm}$, with a low level of $1,000 \mathrm{ppm}$. Chemical treatment M-25 at a level of $60 \mathrm{ppm}$ is used to control algae, bacteria, and fungi. A chemical analysis of the water is presented in Table 37.

Table 37. STORAGE WATER CHEMICAL ANALYSIS

TELEX COMMUNICATIONS

FEBRUARY 4,1981

\begin{tabular}{ll} 
CHEMICAL/PHYSICAL PROPERTY & ANALYSIS \\
\hline Water Content by KF* (\%) & 97.6 \\
pH & 9.1 \\
Reserve Alkalinity & 2.2 \\
Specific Gravity & 1.003 \\
Ash (\%) & 0.22 \\
Sodium (mg/liter) & 940 \\
Copper (mg/liter) & 0 \\
Iron (mg/liter) & 1 \\
Silicon (mg/liter) & 2 \\
Aluminum (mg/liter) & 0 \\
Calcium (mg/liter) & 11 \\
Magnesium (mg/liter) & 5 \\
Zinc (mg/liter) & 1 \\
Boron (mg/liter & 200 \\
Chlorides (mg/liter) & 6 \\
Sulfates (mg/liter) & 490 \\
Ethylene Glycol (\%) & 0 \\
Propylene Glycol (\%) & 0 \\
Karl Fischer method. &
\end{tabular}

There is an automatic water makeup system to replace water lost through leaks, evaporation, and sump overflows. From system startup to February $1979,4,340$ gallons of makeup water were added. In the 1980-1981 heating season, about 200-300 gallons of makeup water were added per month.

\section{3 .2 Controls}

There are no controls on the storage subsystem. 


\section{3 .3 Reliability and Maintainability}

There were no failures, nor was maintenance required, other than the addition of rust inhibitor.

\section{3 .4 Maintenance and Repairs}

None.

11.4 HEATING SUBSYSTEM OPERATIONAL HISTORY

\section{4 .1 Operaliull}

The solar heating loop always operated continuously throughout the heating season. As explained in the system description, there is always flow (130-165 gallons per minute) out of the storage tank, but the flow to the load is bypassed more as the heating demand decreases. The bypass operation was not monitored by the NSDN, which measured only the flow out of the storage tank, and the supply and return temperatures. There was no minimum tank temperature for circulation to the load, and the water was (very rarely) circulated at a temperature as low as $58^{\circ} \mathrm{F}$ after an extended period of cloudy weather. Below about $64^{\circ} \mathrm{F}$ (depending on the time of day, etc), return water would be as warm or warmer than the supply water. The storage tank was usually much warmer than $640 \mathrm{~F}$ (the lowest storage temperature in January 1981 was $76^{\circ} \mathrm{F}$ ), and the storage tank got as hot as $1670 \mathrm{~F}$ in January 1981, when the average daytime temperature was $410 \mathrm{~F}$.

The maximum rate of solar energy delivered by the storage tank was about 800,000 BTU/hour, representing. 165 gallons per minute flow with a $100 \mathrm{~F}$ temperature drop. For short periods (five to $10 \mathrm{~min}$ utes) a $160 \mathrm{~F}$ temperature drop was occasionally recorded.

The two space heating load pumps never ran together, but one was used as a backup for the other. The pumps were alternated periodically to even out the wear.

\section{4 .2 Heating Subsystem Controls}

The operation of the controls was described in section 2.2.3. Instrumentation was not extensive enough to determine how the controls actually operated during the monitoring periods.

\section{4 .3 Reliability and Maintainability}

The space heating pumps have had no failures. 
On October 24, 1978, a hydronic heating coil froze and burst, flooding the west building. There was about $\$ 1,000$ worth of damage caused by the flooding.

The burst coil was a result of improper integration between the solar space heating subsystem and the vapor compression air conditioning system. When the outside temperature was $40^{\circ} \mathrm{F}$, the air conditioner came on and then the outside vents opened. The cold air caused the freeze stat to cut the blower off, but the air conditioner continued to run. The freeze stat also caused the room thermostat valve to fail closed, so warm water was not circulating through the solar heat coil. This coil, which is only 12 inches from the air conditioner, froze and burst.

\section{4 .4 Maintenance and Repair}

To correct the above problem, the following actions were taken:

- The room thermostat valves were changed to fail open.

- The air conditioning and heating were interlocked so they would not run simultaneously.

- The freeze stat sensor was allowed to close the outside damper.

At the same time, the air mix controller was moved from downstream of the solar coil to upstream of the solar coil. In the old location, the controller had called for too much outside air, resulting in a waste of solar heat. 
THIS PAGE

\section{WAS INTENTIONALLY LEFT BLANK}




\subsection{DESIGN}

The original design estimated cost of the Telex Communications solar system was $\$ 360,482$. The breakdown of this estimate is presented in section 3.5. This estimate proved to be too low and was raised to $\$ 557,031$. (The contract price was $\$ 459,441$, so design changes were made to reduce the price.). A discussion of these matters is found in section 5 .

\subsection{CONSTRUCTION}

Detailed subsystem construction cost analysis is presented in section 8.3. The total system cost is presented in Table 38.

No allowance has been made for general Overhead and Profit (OHEP) or General and Administrative (G\&A) costs. It is important to note that at Telex Communications, subcontractors were significant participants in the system construction. All subcontract costs listed below and in Section 8 include the subcontractors' OHEP. The labor and materials breakouts presented in section 8 and Table 38 represent the costs incurred by the general contractor directly.

Table 38. TOTAL SYSTEM CONSTRUCTION COST SUMMARY

TELEX COMMUNICATIONS

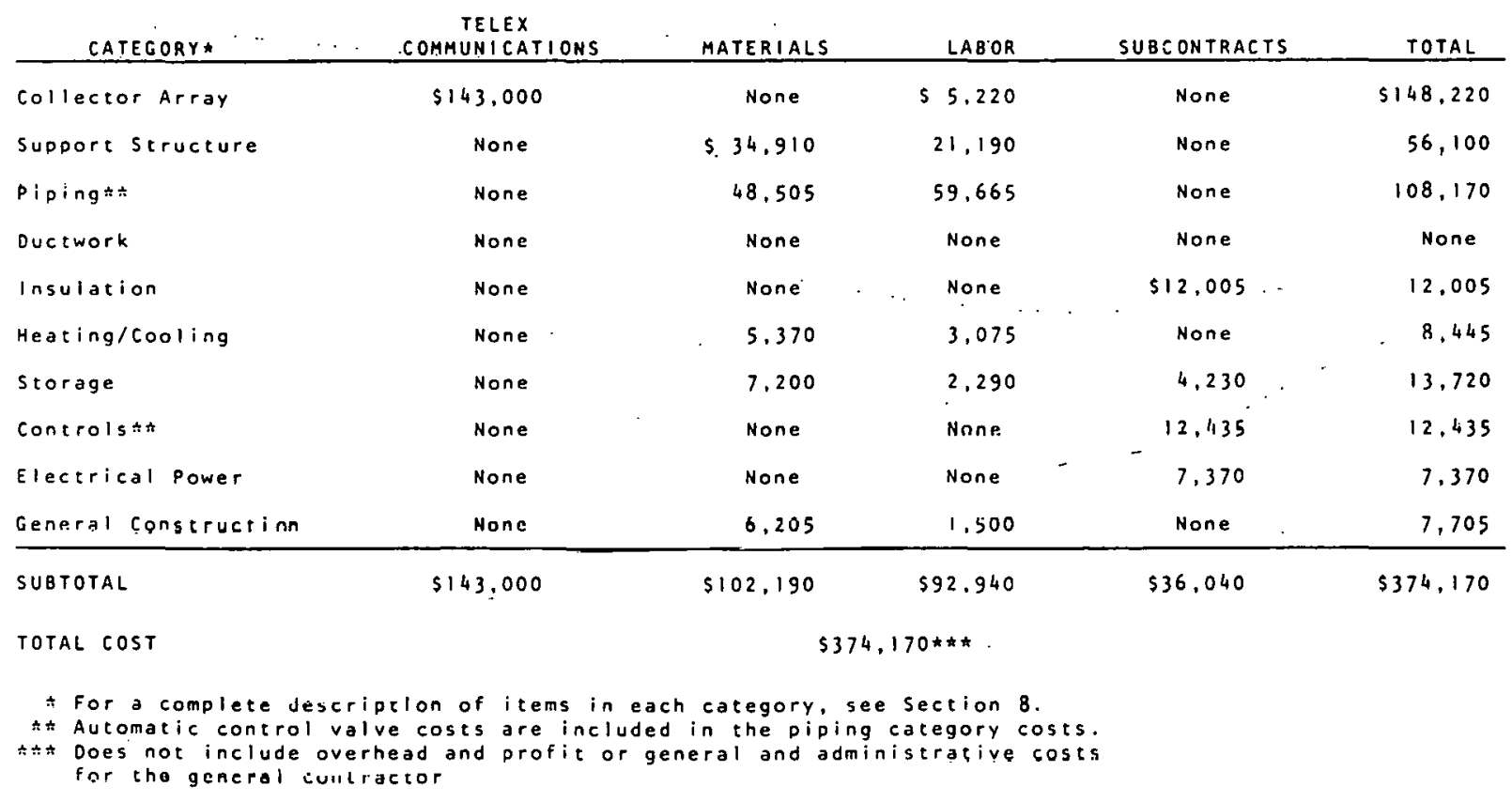


In order to standardize solar system cost analysis, the NSDN Solar Project Cost Report series added a standard percentage of $25 \%$ for overhead and profit to general contractor bare costs and $10 \%$ to all subcontract costs. This brings the Telex communications solar system construction cost with overhead and profit to $\$ 462,305$. In addition, the cost of the system design was $\$ 28,675$. The contract total cost was $\$ 552,136$ including instrumentation, and $\$ 525,728$ not including instrumentation. The difference, $\$ 34,748$, between the construction and design cost and the contract total represents startup costs and instrumentation changes. The Department of Energy's share of the cost was $\$ 409,066$.

\subsection{SYSTEM STARTUP}

- The existing fresh-air dampers did not closo tightly enough to prevent the water coils from freezing. The ducts were replaced and felt tipped louvers installed at a cost of $\$ 3,065$.

- Wood braces were added to the collector support trusses at a cost of $\$ 2,034$.

- The repairs to the system because of the freeze-up cost in excess of $\$ 24,000$.

- Adding heat-taped, insulated, 3/4-inch and two-inch standpipes and moving the balancing and gate valves to vertical pipes cost abour $\$ 3,000$.

- Repairing the freeze-dallaged collector rows cost an estimated $\$ 10,800$.

- Kepairing che flexille hosez and clamps cost $\$ 3,885$ for materials plus $\$ 5,000$ in labor. The cost of heattaping the outside valves and modifying the control system could not be determined.

\subsection{OPFRATION AND MAINTENANCE}

No cost figures are available, but the system has been relatively trouble-free since the freeze-up, with maintenance consisting of occasional tightening of collector hose clamps and maintaining the concentration of rust inhibitor.

\subsection{SUBSIDIES AND INCENTIVES}

The Department of Energy paid $\$ 409,066$ of the contract total of $\$ 525,728$. 
SECTION 13

REFERENCES

1. Kirkpatrick, D.L., Flat-Plate Solar Collector Performance Data Base and User's Manual, SERI/STR-254-1515, JuIy 1983.

*2. National Solar Data Network, SOLAR/0003-80/17, January 1980, Vitro Laboratories, Silver Spring, Maryland

*3. Solar Project Description, Telex Communications, Inc., July 1979, Mueller Associates, Inc.

*4. Solar Project Cost Report, Telex Communications, Inc., July 1979, Mueller Associaties, Inc.

*5. Solar Energy System Performance Evaluation, Telex Communications, November 1979 through April 1980, SOLAR/2033-80/14, Vitro Laboratories, Silver Spring, Maryland.

*6. Solar Performance Bulletin, Telex Communications, November 1979 through April 1980, SOLAR/2033-80/16, Vitro Laboratories, Silver Spring, Maryland.

* Copies of these reports may be obtained from Technical Information Center, P.0. Box 62, Oak Ridge, Tennessee 37831 . 


\section{APPENDIX A}

NATI ONAL SOLAR DATA NETWORK

PR OGRAMMATIC INFORMATI ON 


\section{NATIONAL SOLAR DATA NETWORK PROGRAMMATIC INFORMATION}

One of the principal objectives of the National solar Heating and Cooling Demonstration Program established by the National Solar Heating and Cooling Demonstration Act of 1974 was the collection and evaluation of solar information, and its dissemination to potential users. In order to achieve this objective and to ensure that all related activities are conducted uniformly, the National Solar Data Program, including the National Solar Data Network (NSDN), was established.

Approximately 5,000 residential and commercial solar demonstration sites have been established since the inception of the National Solar Heating and Cooling Demonstration Program. Approximately 150 of these sites were instrumented and included in the National Solar Data Network.

The Department of Energy (DOE) had responsibility for the solar energy program; however, other government agencies were significantly involved. Those agencies include the Department of Housing and Urban Development, the National Aeronautics and Space Administration, the Department of Defense, the National Bureau of Standards, Argonne National Laboratory, and the Department of Health, Education and Welfare. State and local governments, portions of the private sector, and other groups within DoE were active participants.

The National Solar Data Program had a major goal to collect and analyze data from solar sites throughout the United States to enable determination of solar energy system performance. Specifically, the data which is generated and collected in support of this program is used to:

1. Improve the general knowledge and understanding of the performance and operating characteristics of solar energy systems.

2. Develop definitive solar energy system performance criteria.

3. Provide a basis for component and system improvements.

4. Estimate the economic importance of solar energy systems in reducing the consumption of conventional fuels.

The National Solar Data Network provided data to meet this major goal. Accurate, consistent, and orderly data was obtained from a variety of solar energy systems, located in many buildings and exposed to differing climatic conditions. The data was collected, organized, maintained and analyzed at a central poinc assuring consistent system analysis and performance evaluation. 


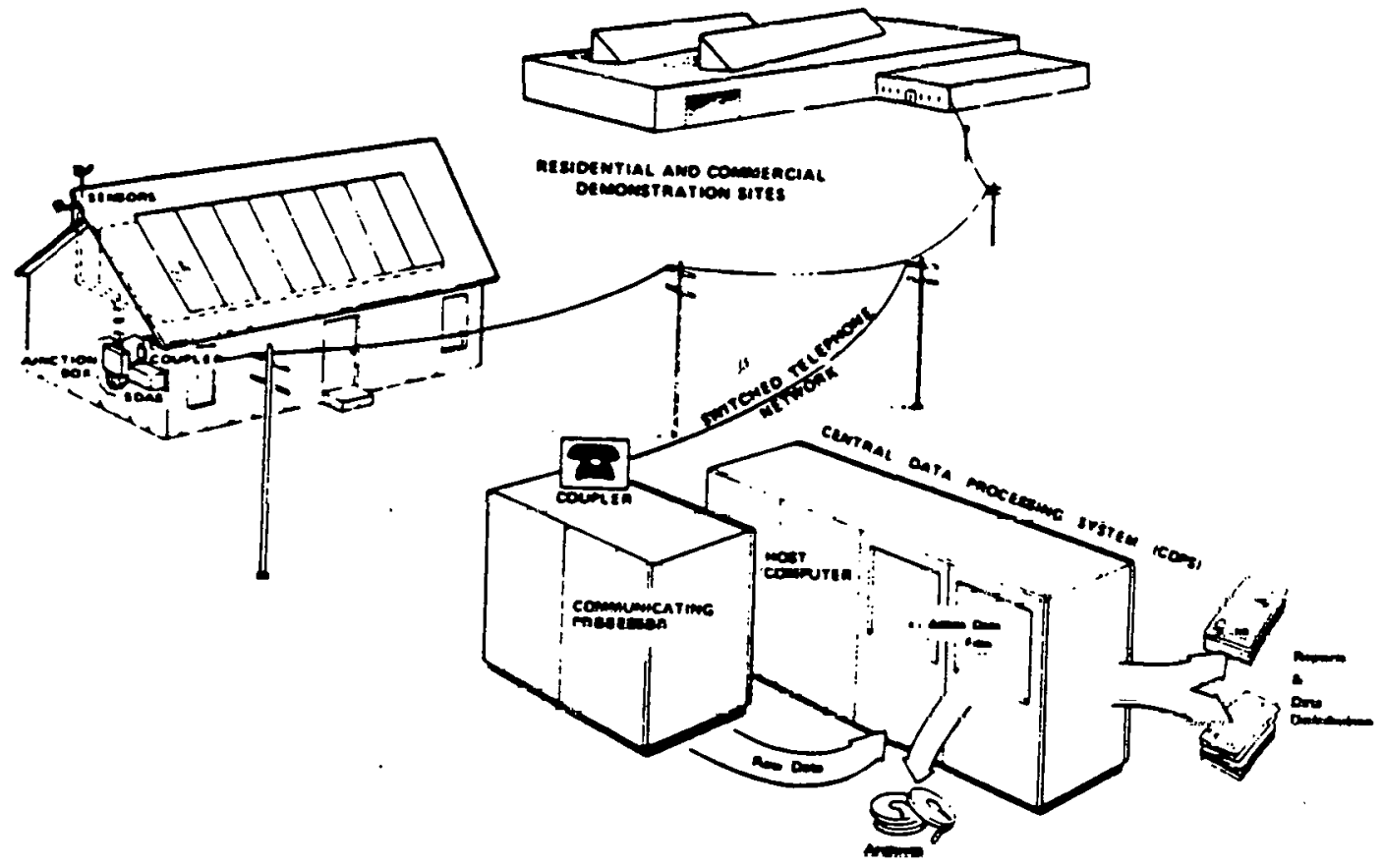

Figure A-1. Schematic Diagram of the NSDN Teleprocessing Network

To meet the goals and objectives of the National Solar Data Program, the National Solar Data Network was operaced ror the Department of Energy by Vitro Corporation. The network concept was based on automatic collection of data from remote solar sites and transmission of this data to a central computer facility. Thus, the Naliunal solar Dota Network was developed to gather, convert, transfer, and analyze solar system data using six basic steps (see Figure $A-2$ ).

1. Evaluate each site and its instrumentation roquirements.

2. Select sensors and personalize standardized data acquisition equlpment in order to meet specific site requirements.

3. Install and check out instrumentation on site.

4. Retrieve automatically collected site data over the telephone network on command from a central computer facility.

5. Process data in centrally located computers; this includes error checking, performance evaluation computations, and data base maintenance. 
6. Analyze data received and document this analysis in a standard report format for distribution.

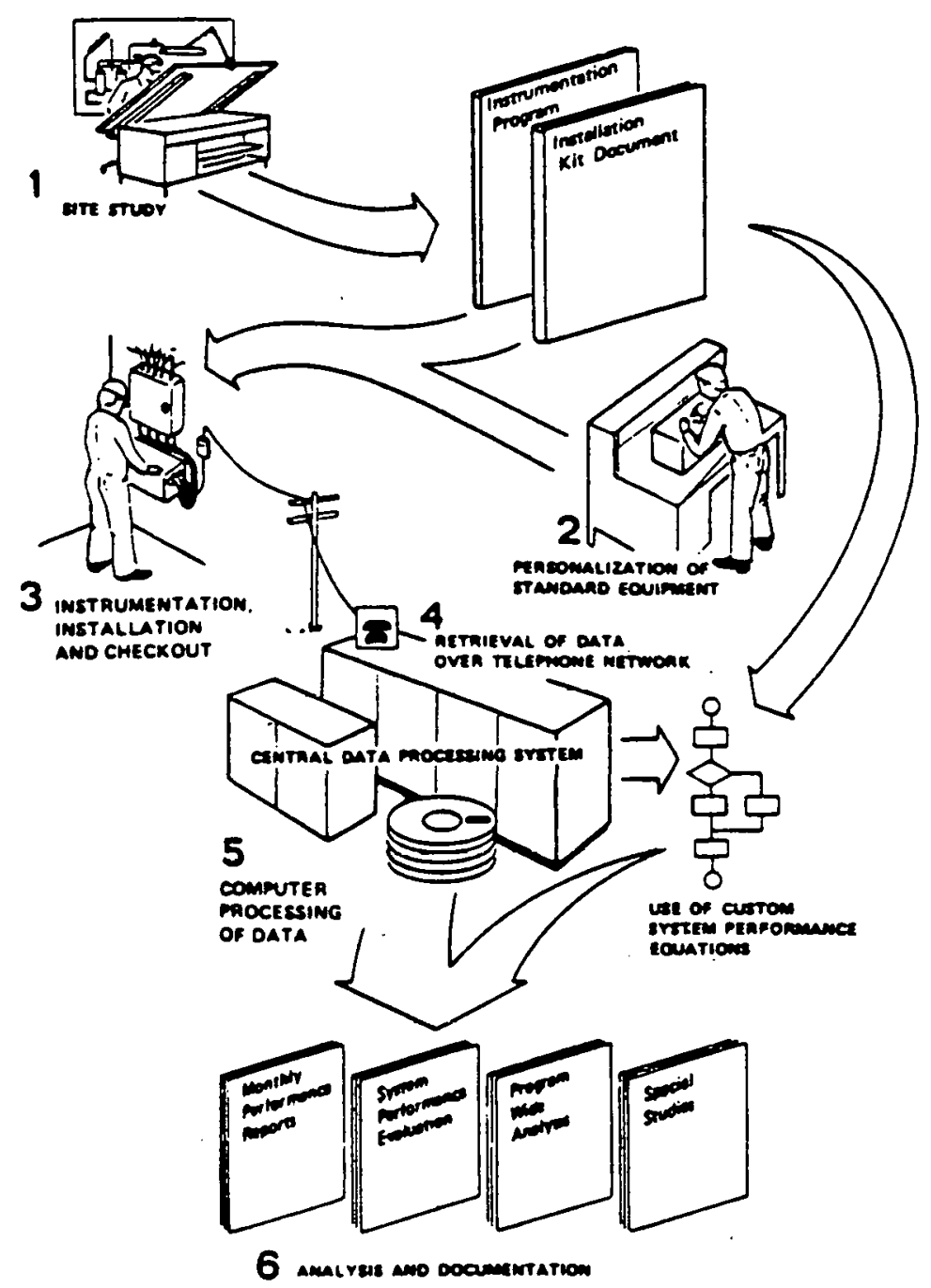

Figure A-2. Instrumentation, Monitoring and Analysis Process

The following discussion will define each step in detail

\section{Site Evaluation}

First, a careful study of the solar energy system design of each demonstration site was conducted. Using detailed information supplied by the solar system designer and the site contractor, the system and its environment was investigated to establish performance evaluation equations and associated site monitoring instrumentation requirements. The details of the site instru-. mentation were documented in the Instrumentation Installation documents generated for each solar site. (See Figure A-3.) 

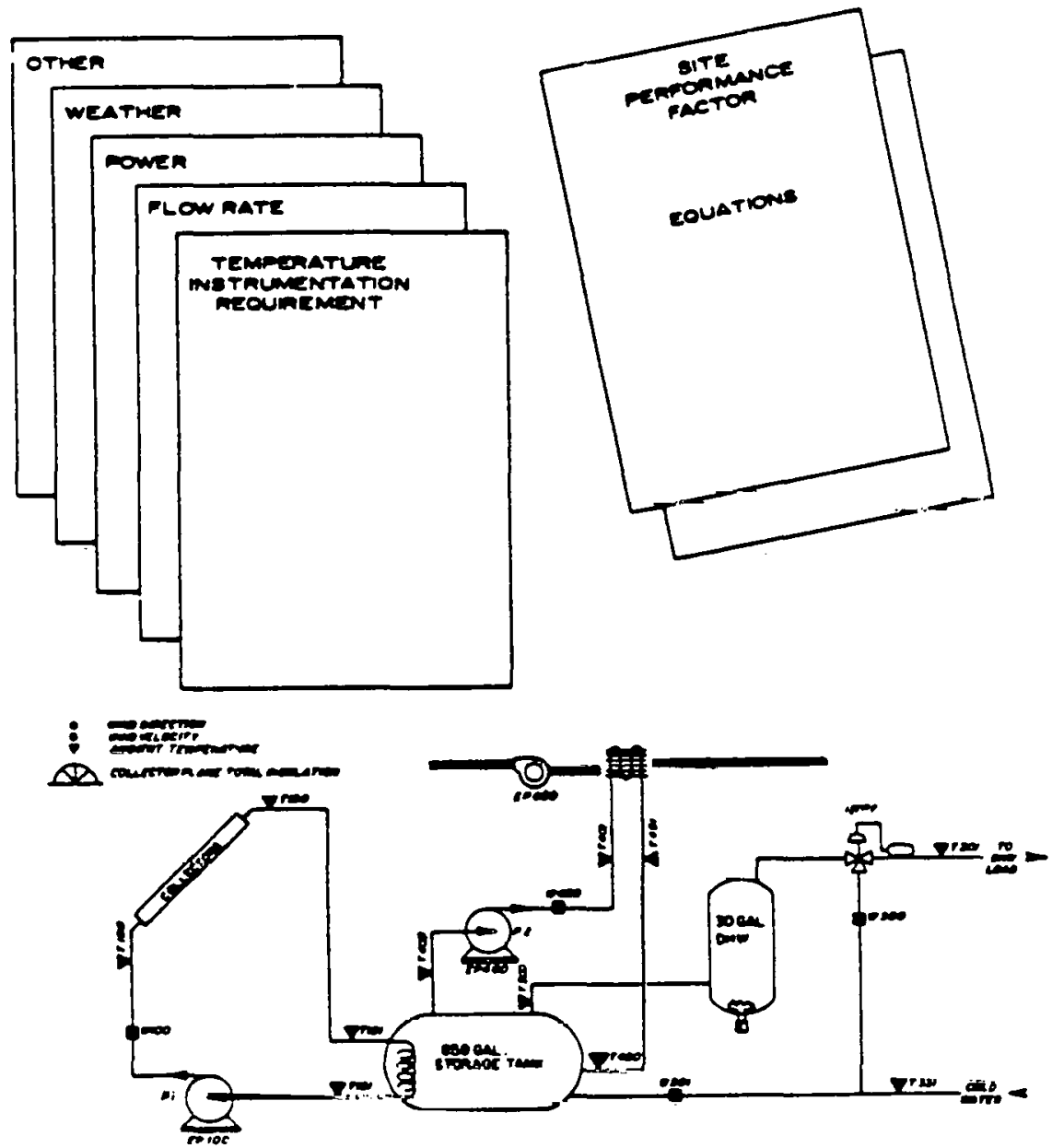

Figure A-3. Site Study - Generates Instrumentation Requirements and Performance Evaluation Equations

Performance evaluation factors were determined using the energy balance concept. Simply stated, energy enterlng a system (or bubsystem) is oqua! to the sum of energy leaving the system, energy accumulated in the system, energy transterred inrough thormal leakage, and conversion inefficiency. As stated in the Instrumentation Program, the sensors selected were lliuse neccssary to accurately and economically dctermine this energy balance.

Performance factors were used to:

1. Determine fossil fuel and electrical energy savings resulting from use of solar energy for space heating, space heating, space cooling, and hot water systems. 
2. Determine total heating, cooling, and hot water thermal energy demands and the fraction of each supplied by solar energy.

3. Measure solar energy system efficiency for converting available solar energy into useful thermal energy.

4. Measure thermal performance of major subsystems or components and thermal interactions between collector array, storage, and energy conversion equipment.

5. Measure occupant's energy usage by means of parameters such as temperature level maintained and hot water demand.

6. Determine major system operational characteristics and degradation over life of the demonstration.

7. Obtain records of incident solar radiation and other pertinent site environmental parameters that affect system performance over life of the site.

\section{Personalization of Standard Equipment}

The second step was to select sensors and personalize the standard data acquisition equipment to meet the requirements specified in the Instrumentation Program. Sensors were selected from a standardized set of sensors which has been established to ensure compatibility with the Site Data Acquisition Subsystem (SDAS) and to minimize software development. The SDAS is a microprocessorcontrolled electronic unit, which collects data from the sensors, stores the data, and on command transmits it to the central

facility. (See Figures $A-4$ and $A-5$.) The scanning process, data treatment procedure, and other functions of the SDAS are directed by a microprogram, which was custom developed for each SDAS, according to the Instrumentation Program for a specific site. Additional personalization was provided through unique wiring of the SDAS and its associated junction-box (see Figure A-6), as described in the sensor Installation Plan. Figures A-7 through A-11 show some of the sensors employed to monitur a solar Domestic Hot Water system. 


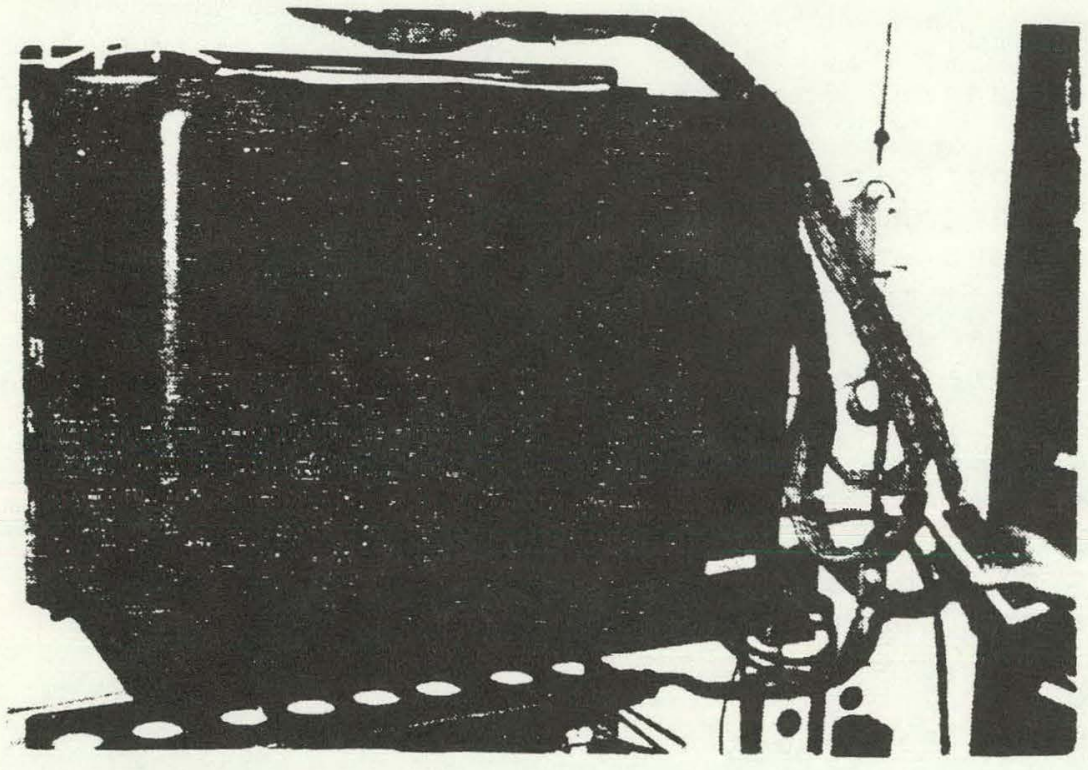

Figure $A-4$.

SDAS Unit mounted on wall. A microterminal is used to obtain sensor measurements for on-site tests.

Figure $A-5$.

SDAS withoul cover reveals internd power supply, tape recorder and arithmetic processor.

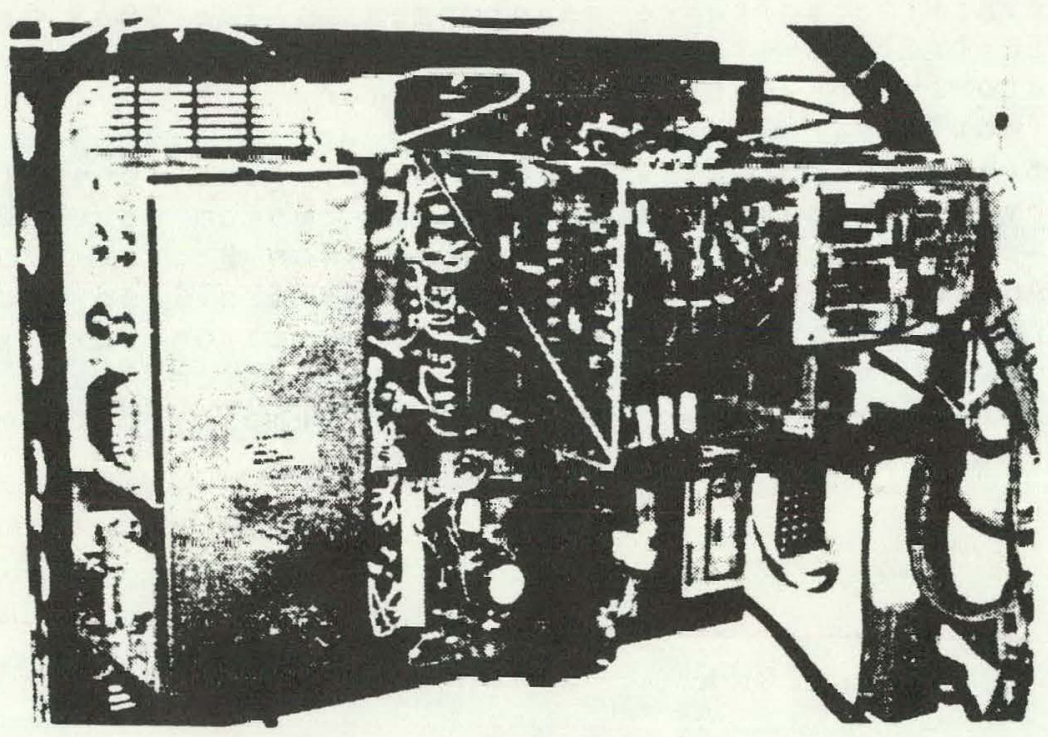




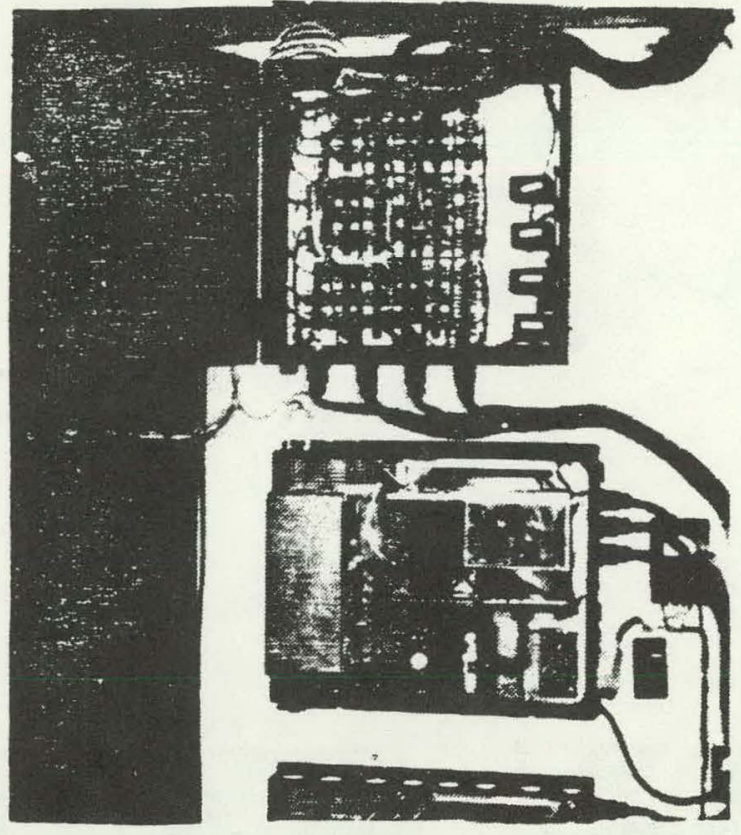

Figure A-6.

SDAS with the associated electrical junction box. Equipment was normally wall-mounted in area easily accessible.

Figure $A-7$.

Eppley Pyranometer mounted

in the plane of the solar collectors
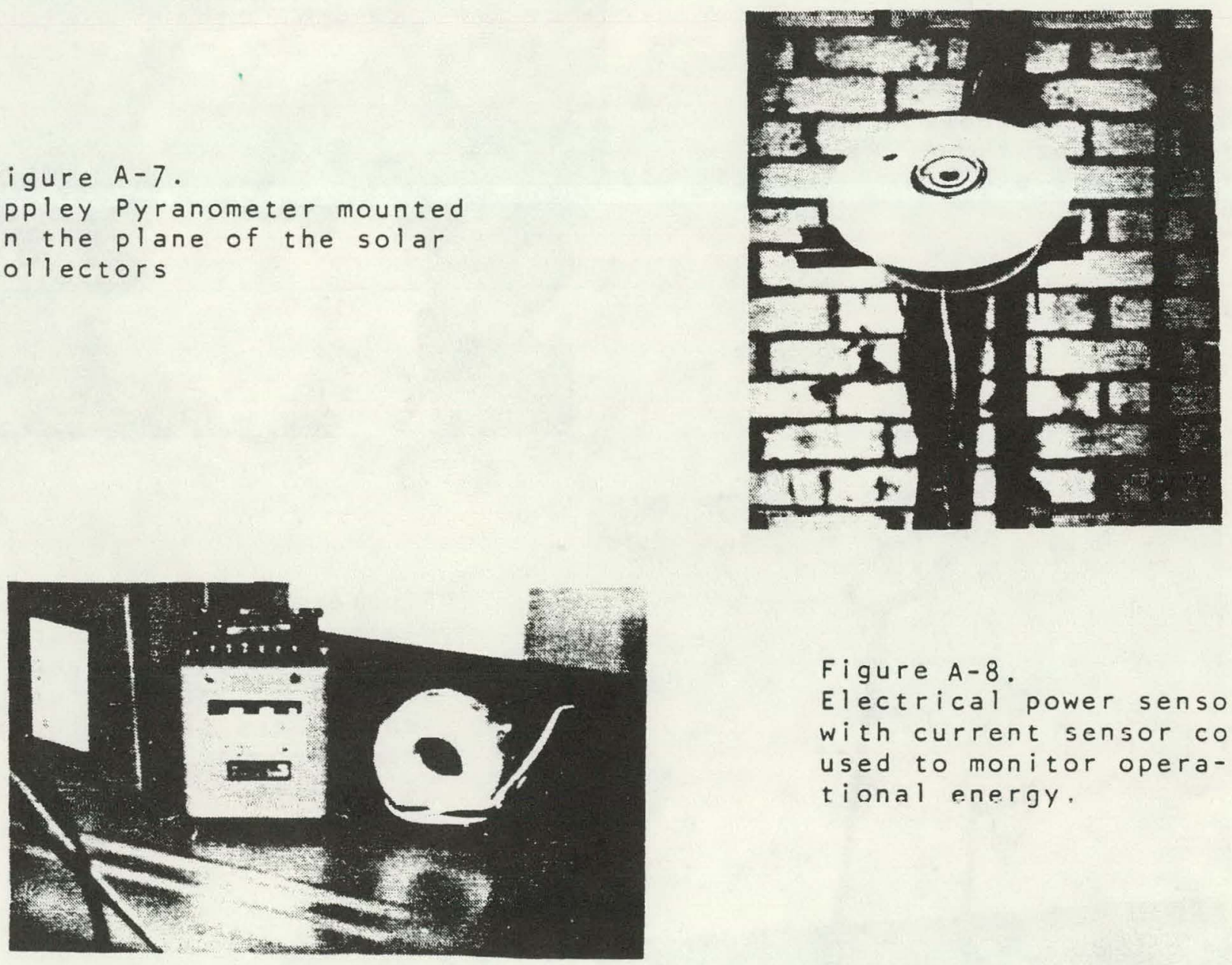

Figure $A-8$.

Electrical power sensor with current sensor coil used to monitor operational energy. 


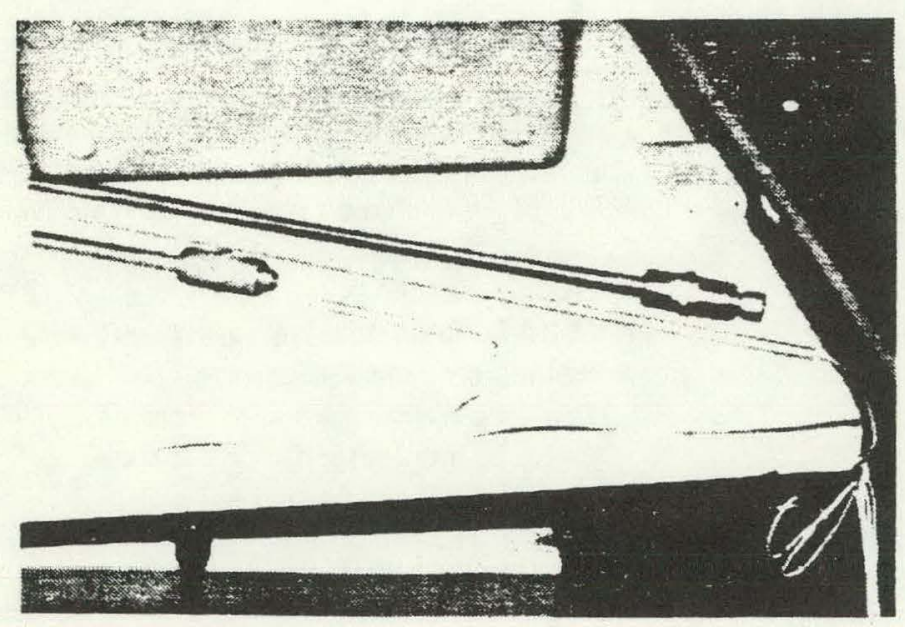

Figure A-9.

Resistance Thermal Devices (RTD) were used to provide accurate temperature measurements. Stainless steel thermal wells were threaded into pipes and house the RTDS.

Figure $A-10$.

Hersey totalizing flow meters provide flow rate data for variable flow loops. Not shown, Ramapo flowmeters used for constant flow rate loops.
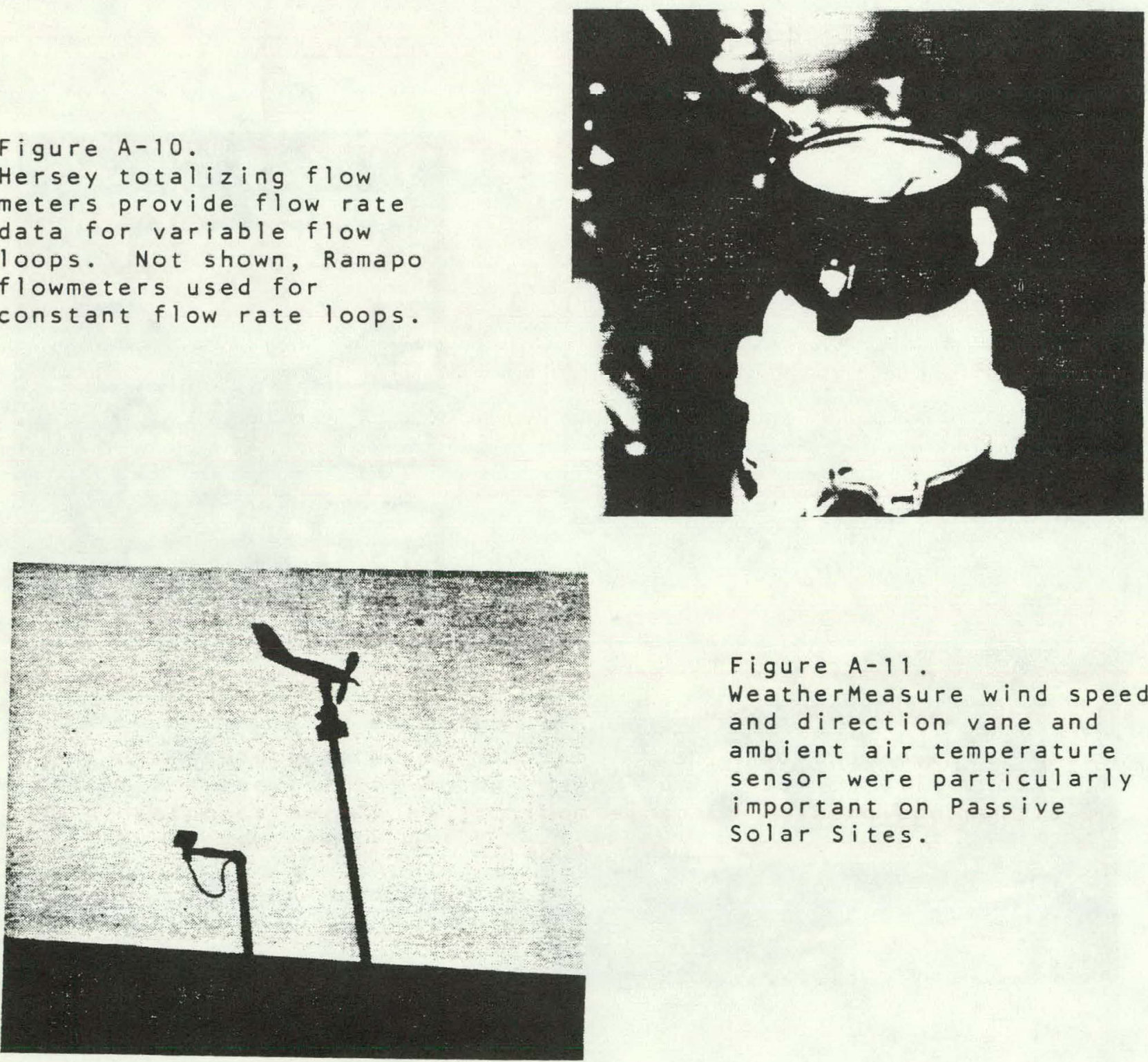

Figure $A-11$.

WeatherMeasure wind speed and direction vane and ambient air temperature sensor were particularly important on Passive Solar sites. 


\section{On-Site Installation and Checkout}

The third step was the installation and checkout of the SDAS and the sensors. The site contractor installed the supplied sensors in accordance with specific installation procedures and verified that the wiring was correct before the SDAS is connected. Sensors were connected to the SDAS through a junction-box, which was wired according to the Installation Plans and at tached to the SDAS by standard interface cables. The SDAS was connected to the National Solar Data Network through a telephone interface installed by the local telephone company. Figure A-12 depicts a typical junctionbox properly wired to reduce line losses and to allow easy access for trouble shooting.

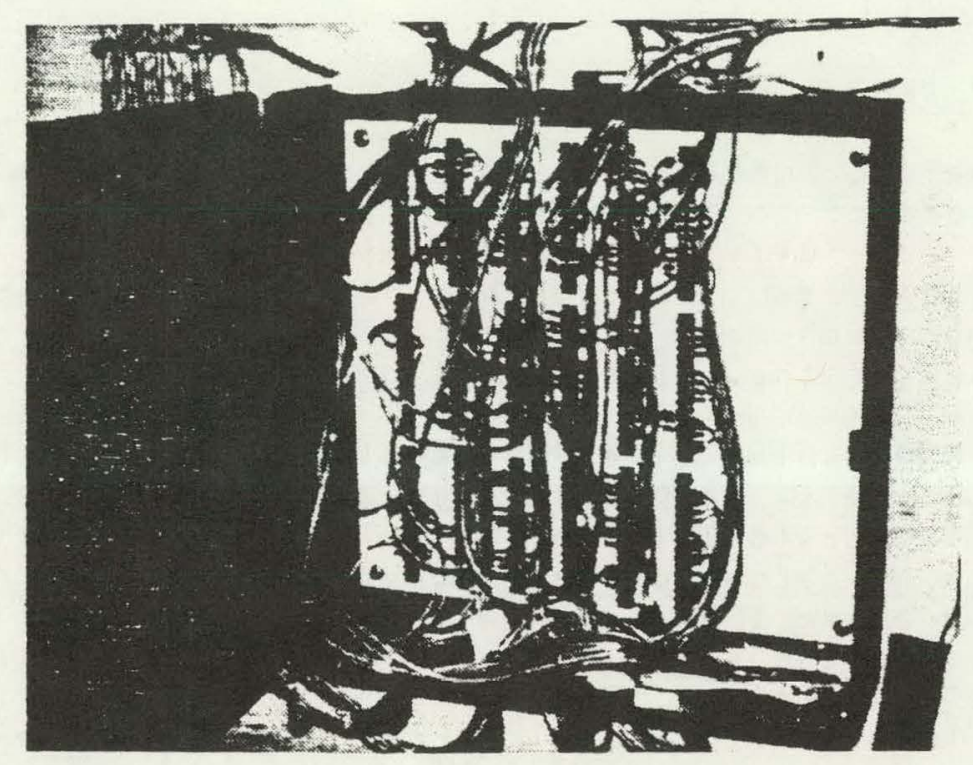

Figure A-12. The junction-box was mounted on a plywood sheet mounted on masonry wall. Wires were terminated with crimped terminals and at tached to terminal boards.

After the SDAS has been installed, checkout procedures were initiated to verify correct local operation of the sensors and data acquisition equipment. Portable monitors were used to obtain a direct readout in Engineering Units of the system measurements and thereby verify that the solar system and SDAS are performing correctly.

The final checkout step was to verify correct transmission of the data to the Central Data Processing System (CDPS). 


\section{Retrieval Over Telephone Network}

After the site data acquisition equipment had been installed and checked out, data retrieval began. Data was transferred from the on-site SDAS to the Central Data Processing System (CDPS) using the standard commercial telephone network. Each SDAS scanned sensor inputs every five minutes and stored the raw data on a cassette tape. The Communications Processor, IBM System 7 , at the CDPS, automatically called each SDAS daily. The SDAS identified itself and then rewound and played back the data sorted on its cassette tape. The Communications Processor received the data, performed error checking and formatting operations, and passed the data to a data storage tape. The SDAS cassette tape was then rewound and proceeded to gather new data. The data storage tape was transferred to the main computer, IBM 3033 , for processing.

\section{Analysis and Reporting}

The energy balance method of systems analysis was used to evaluate the performance of solar systems. Figure A-13 illustrates this process. By carefully monitoring the energy flow patterns

throughout the system, this method not only provided a measure of efficiency for each major component, but it also provides a built-in check of the instrumentation.

Each of the NSDN solar sites was analyzed on a monthly basis. Data collected daily was integrated and performance factors were generated using customized software. Figure A-14 is a summary page for the month of March for one NSDN site. The purpose of this page was to provide the reader with all of the pertinent information regarding the solar system's performance without burdening the reader with details. The remainder of the monthly report contains daily statistics, which could be used to explain operational anomalies. In addition to the monthly reports, the solar analysts also received plots of specific sensor values on a daily basis. This enabled the analysts to detect problems as they occur.

Seasonal reports were also prepared for each of the NSDN sites at the end of the solar system's load season. Since the performance of an individual system was based upon a large number of uncontrollable variables, the evaluation of a system over a larger time horizon was frequently preferable. The seasonal reports provided the same information as a monthly report, however, the conclusions may be drastically different than an individual monthly analysis. The reports also acted as a better check of the system's performance since most systems were designed to operate efficiently over a long time horizon, not a given month. 


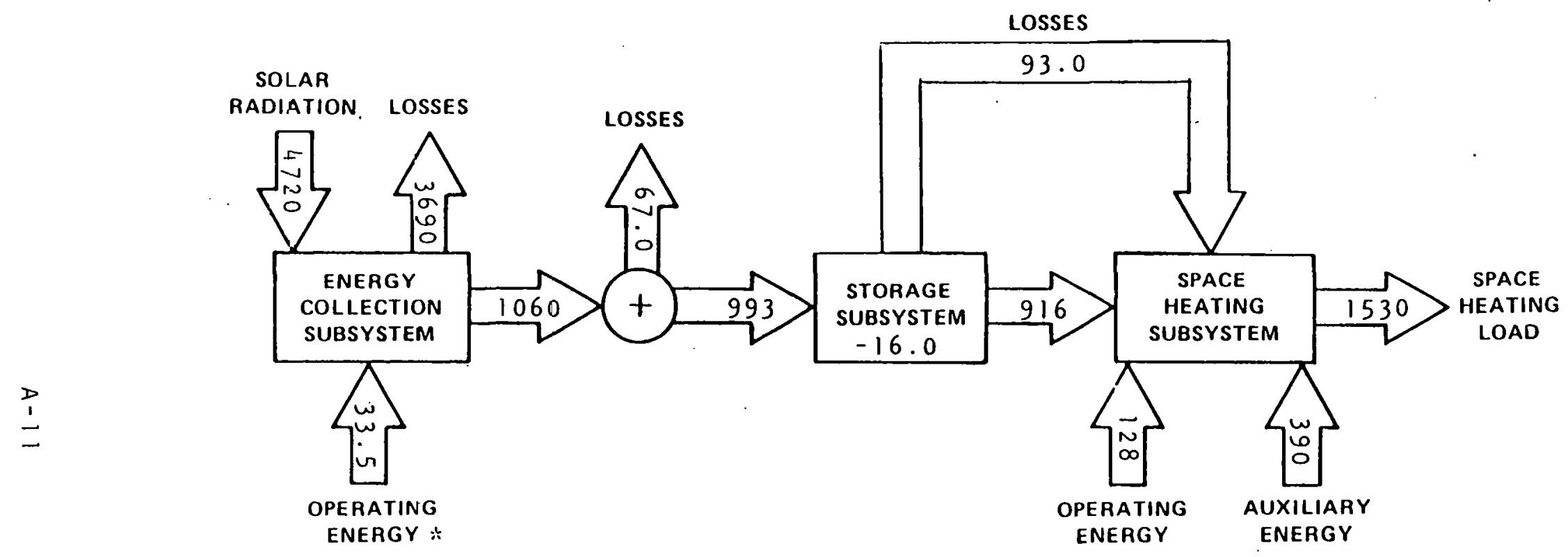

* Six million BTU motor losses contributed to space heating load.

Figure A-13. Energy Flow Diagram for Telex Communications 1979-1981

(Al) figures in million BTU) 


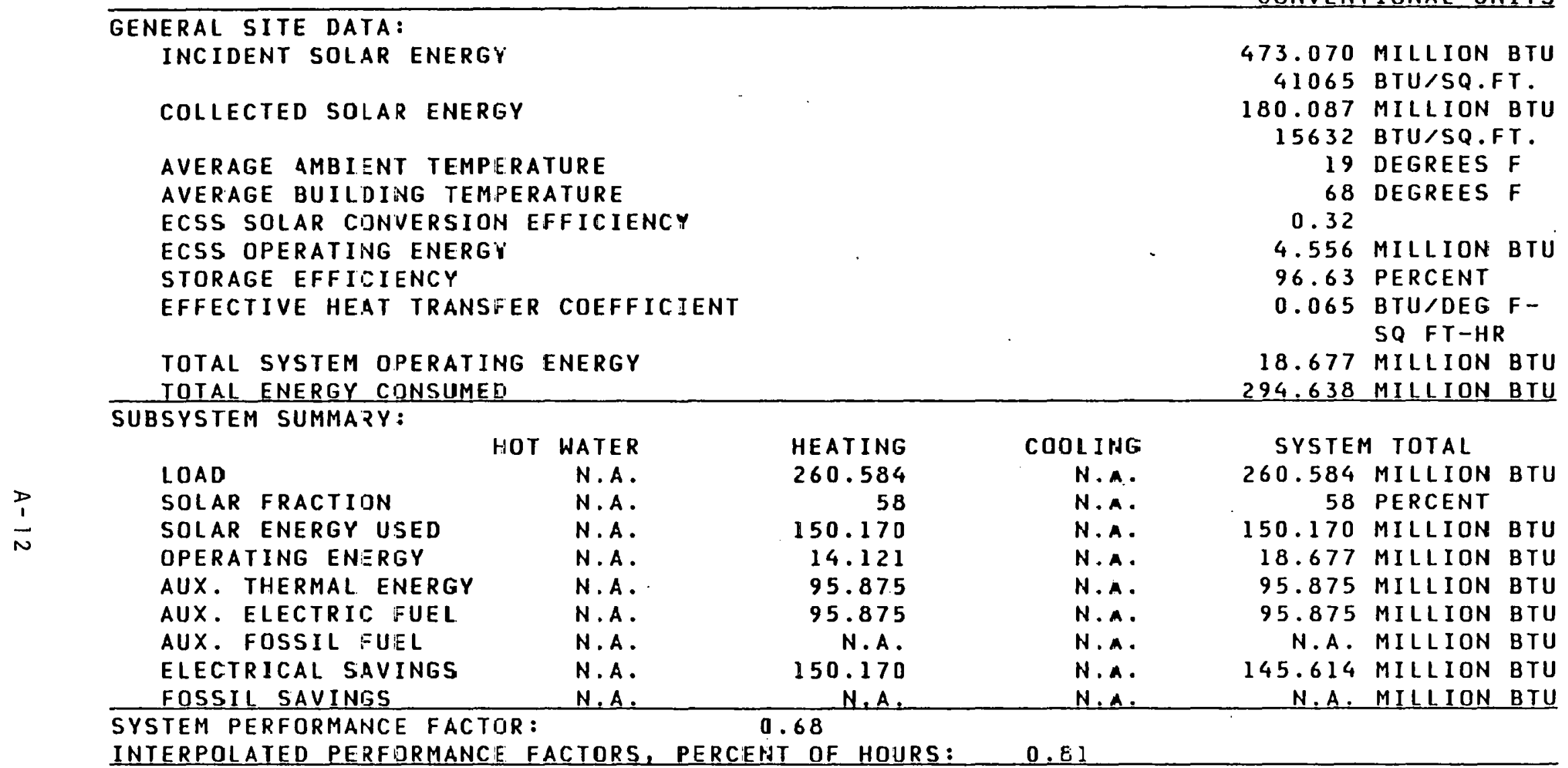

* = UNAVAILABLE; N.A. = NOT APPLICABLE; I = INVALID;E = ESTIMATED.

REFERENCE: USER'S GUIDE TO MONTHLY PERFORMANCE REPORTS, NOVEMGER 1981. SOLAR/D004-81/18

READ THIS BEFORE TURNIMG PAGE.

Figure A-14. Monthly Report: January 1981

Site Summary: Telex Communications 
Comparative reports were also prepared periodically for classes of solar systems. A single comparative report may be based on 20 or more domestic hot water or space heating systems for the purpose of highlighting the effectiveness of systems in a particular environment or under specific load conditions or to identify system components which consistently operate well. 


\section{APPENDIX B}

PRELIMINARY DESIGN DRAWINGS 


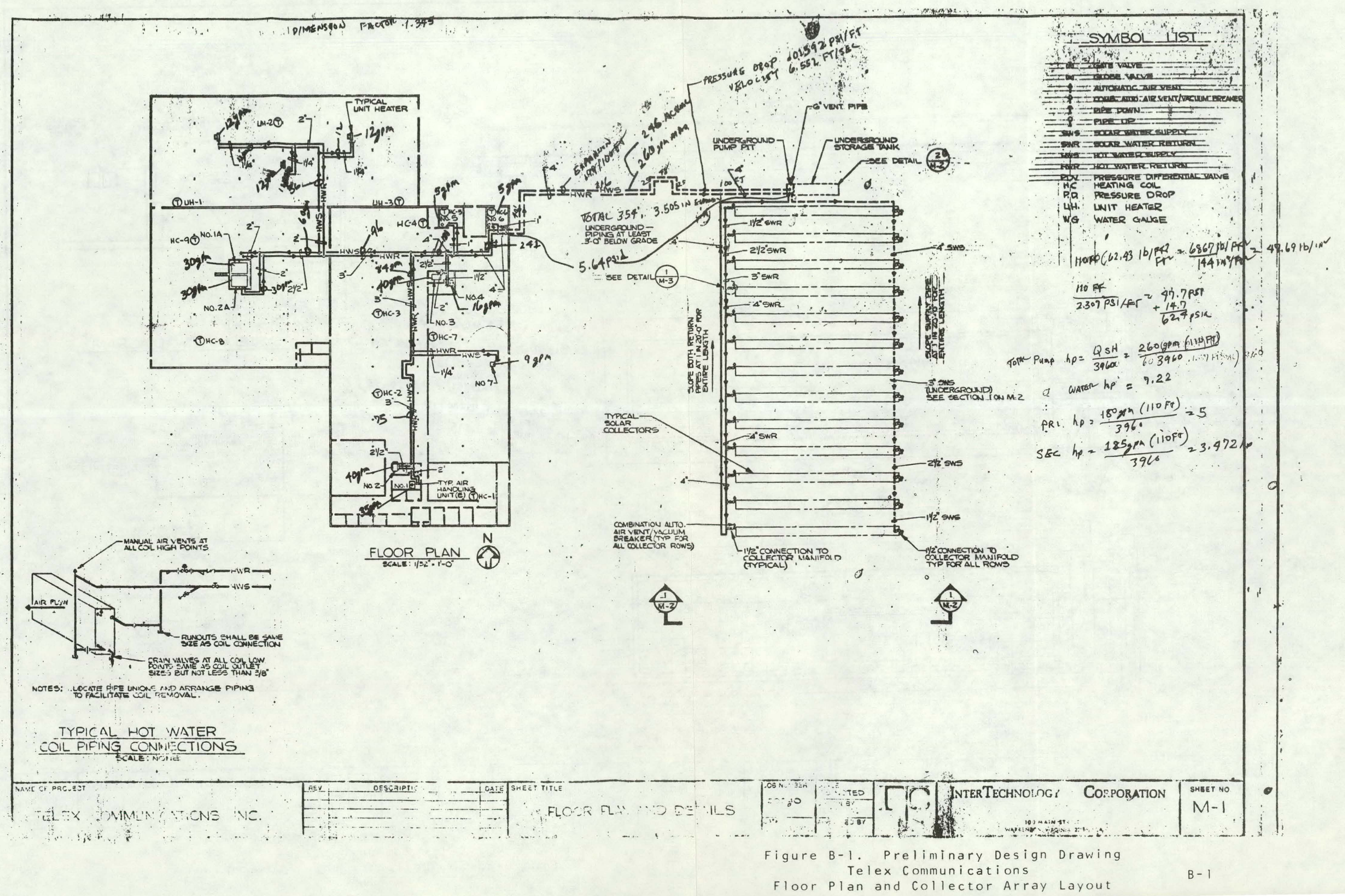




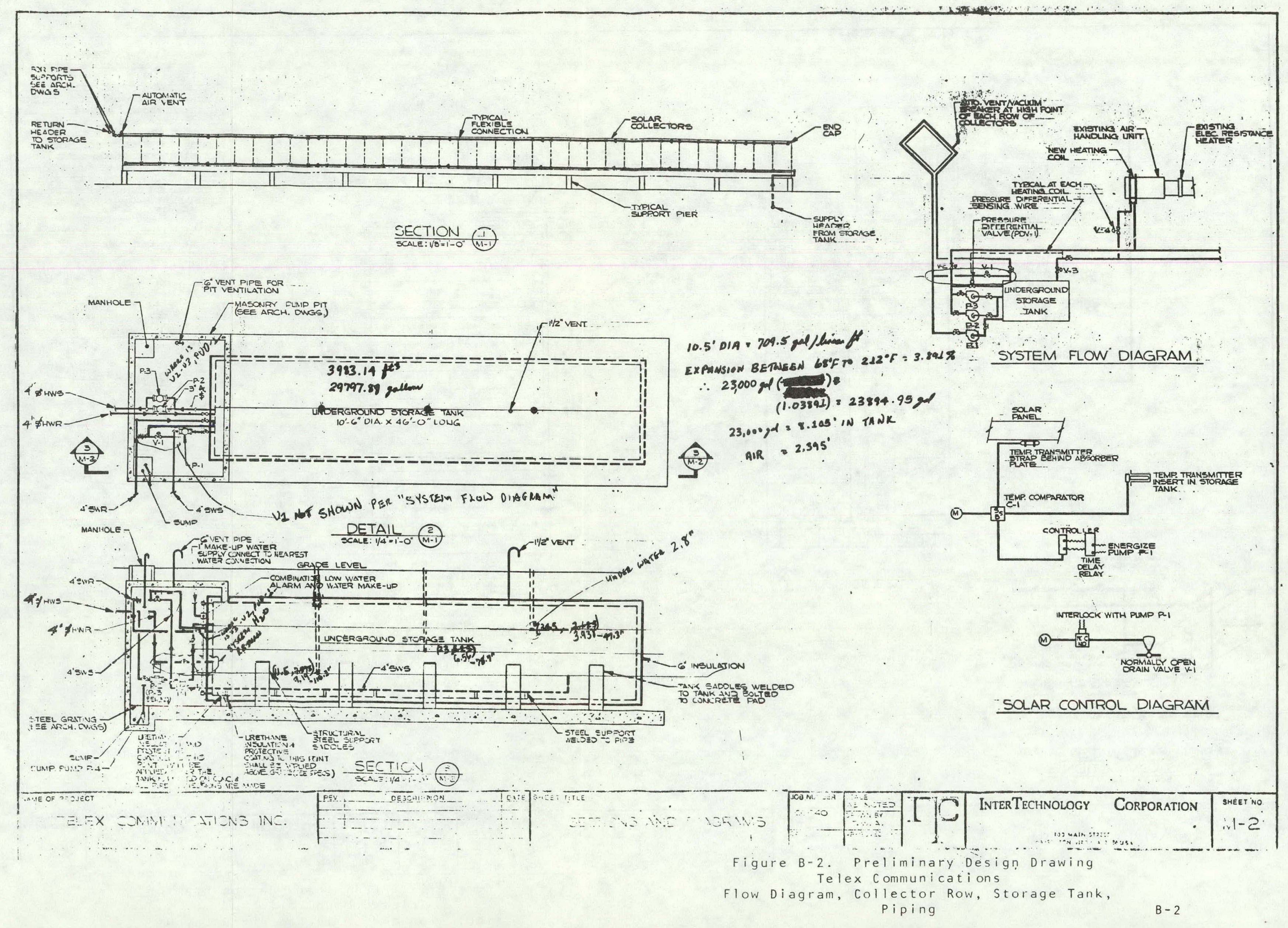


APPENDIX C

FINAL DRAWINGS 


\section{TELEX COMMUNICATIONS, INC.}
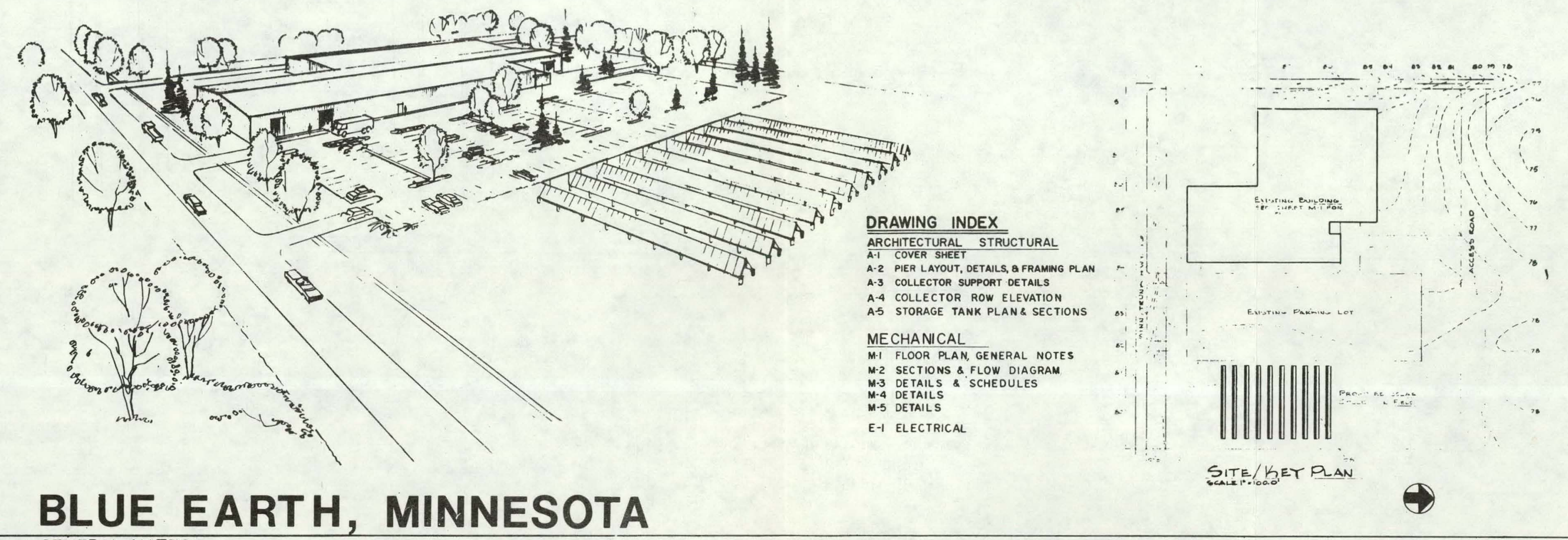

\section{BLUE EARTH, MINNESOTA}

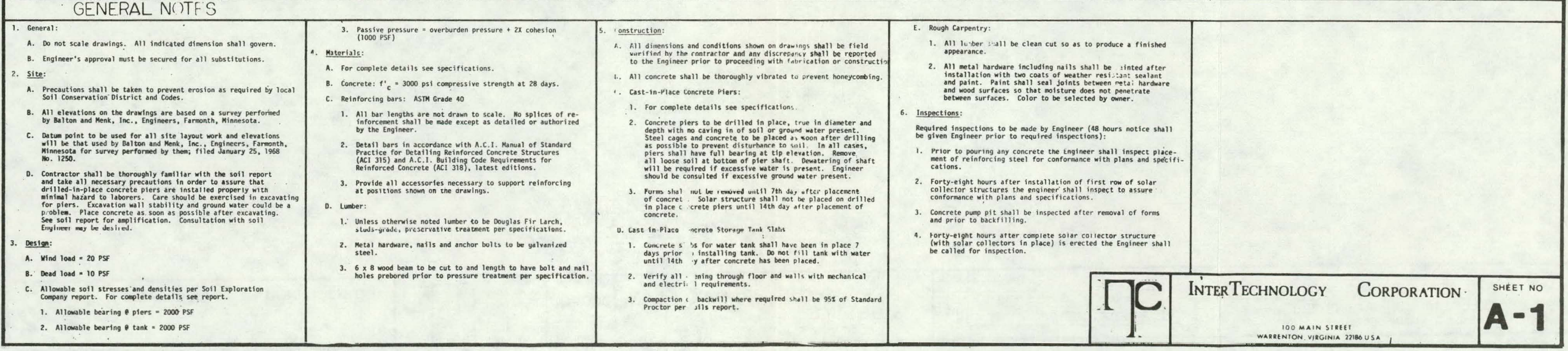

Figure $c-1$. Final Drawing 


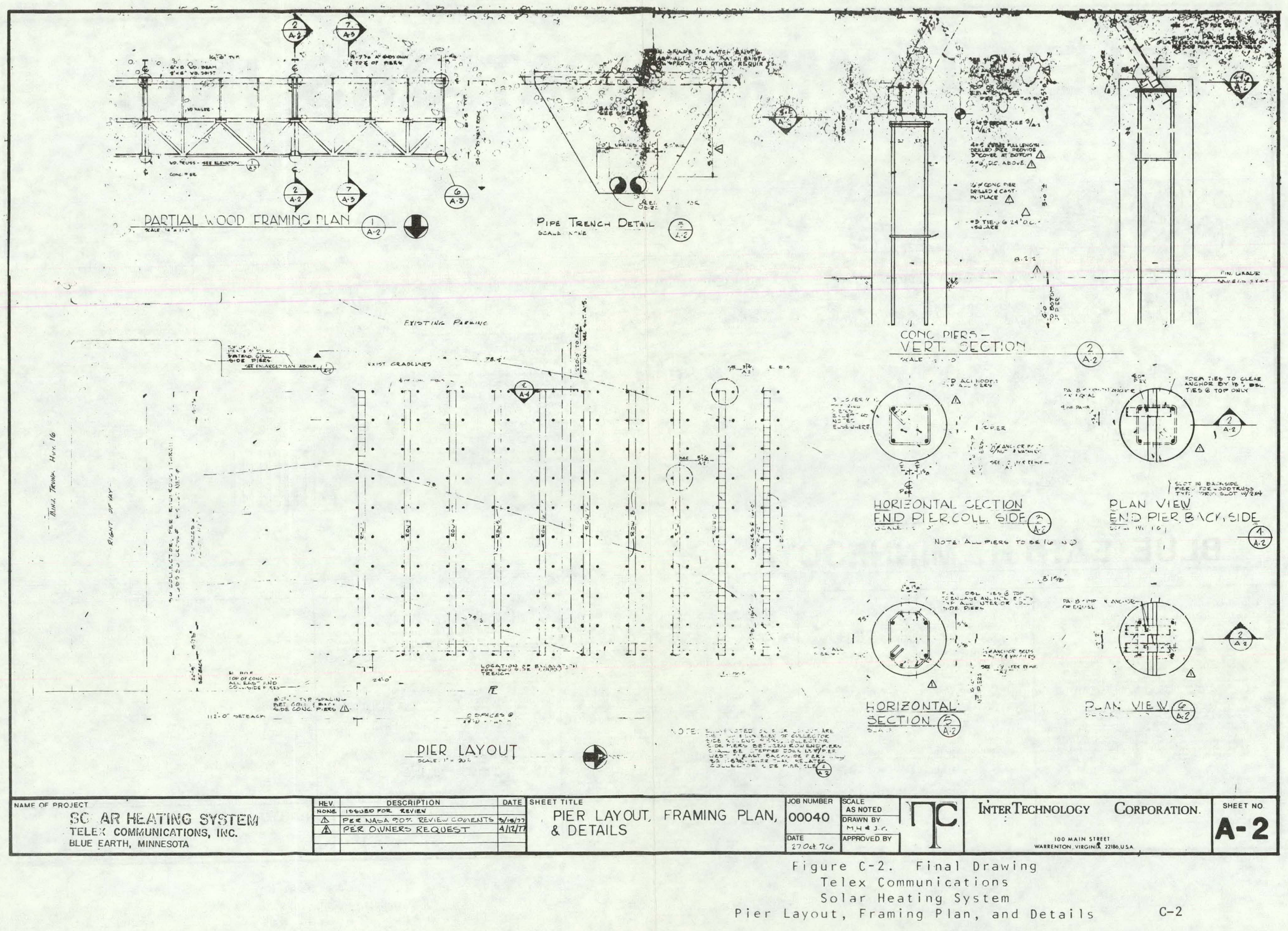




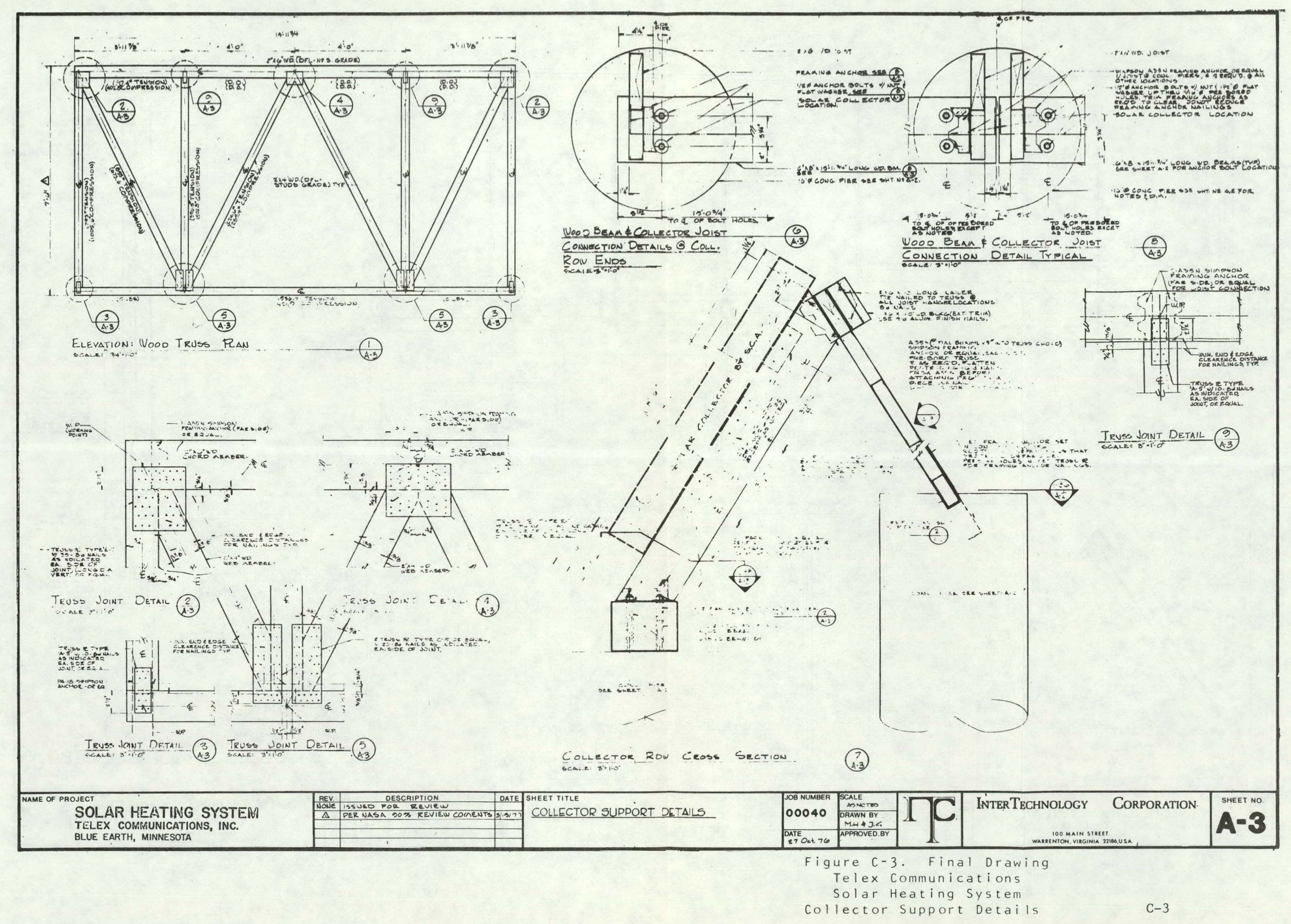




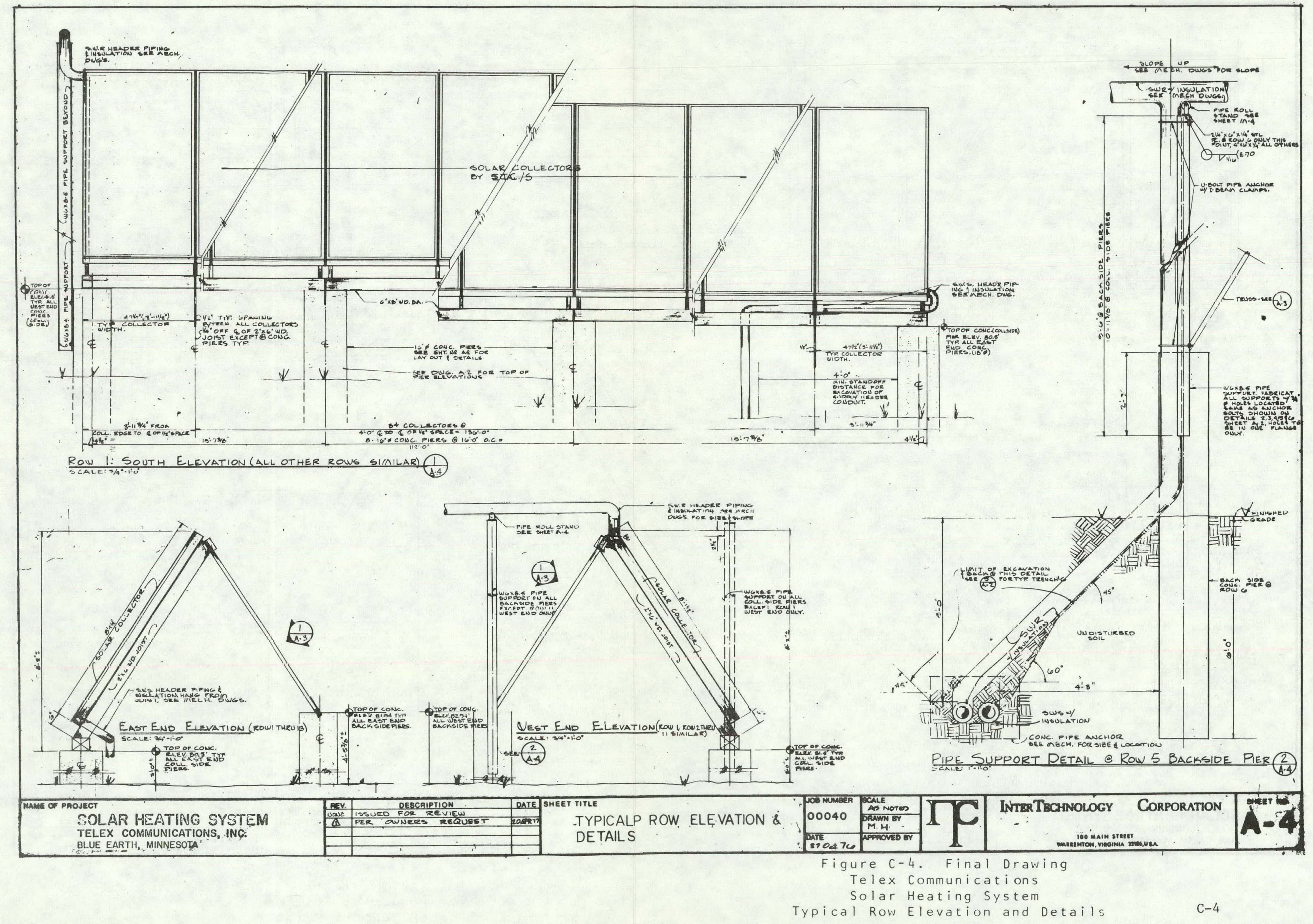




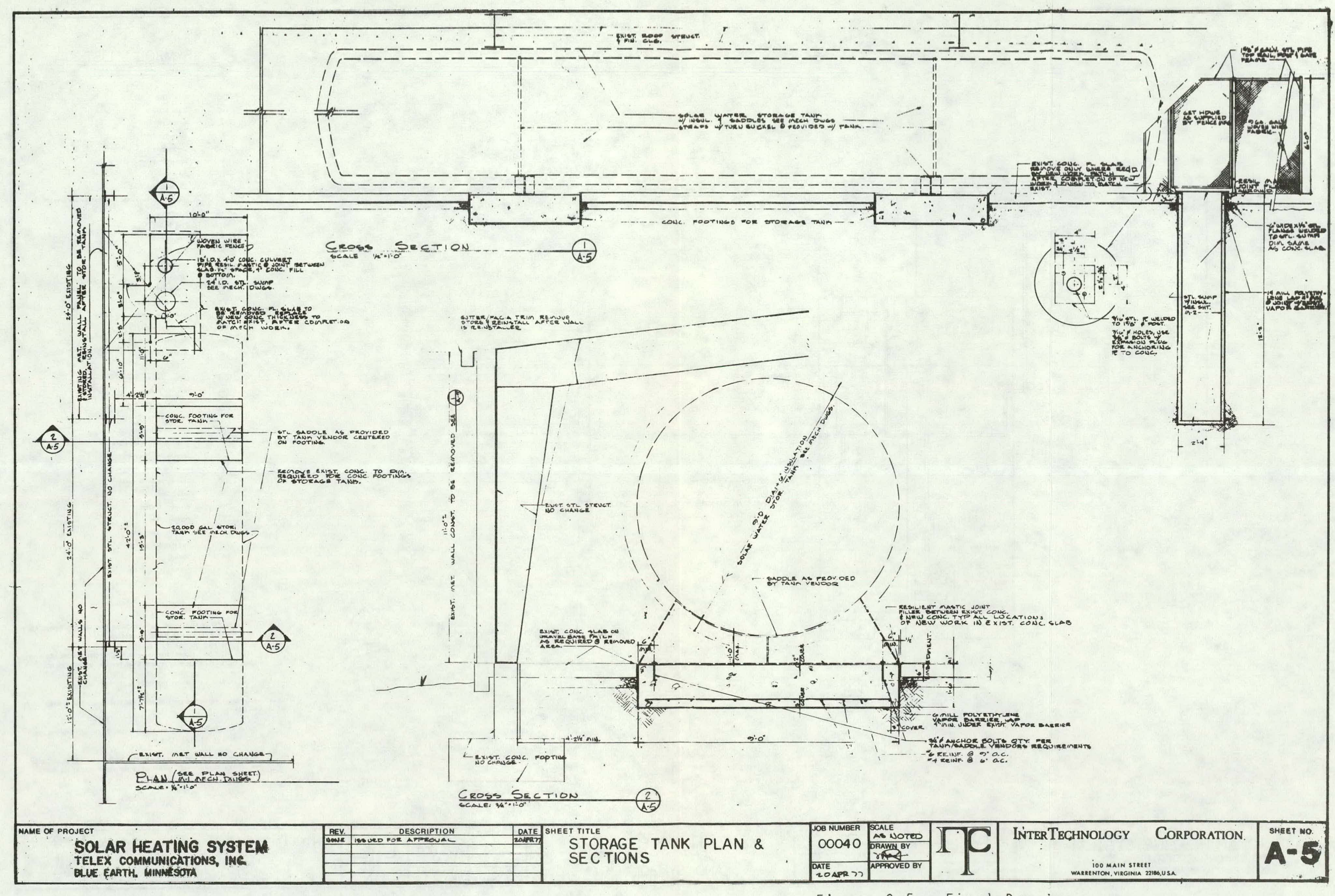

Figure C-5. Final Drawing Telex Communicat $i$ ons

Storage Tank Plan and Sections 


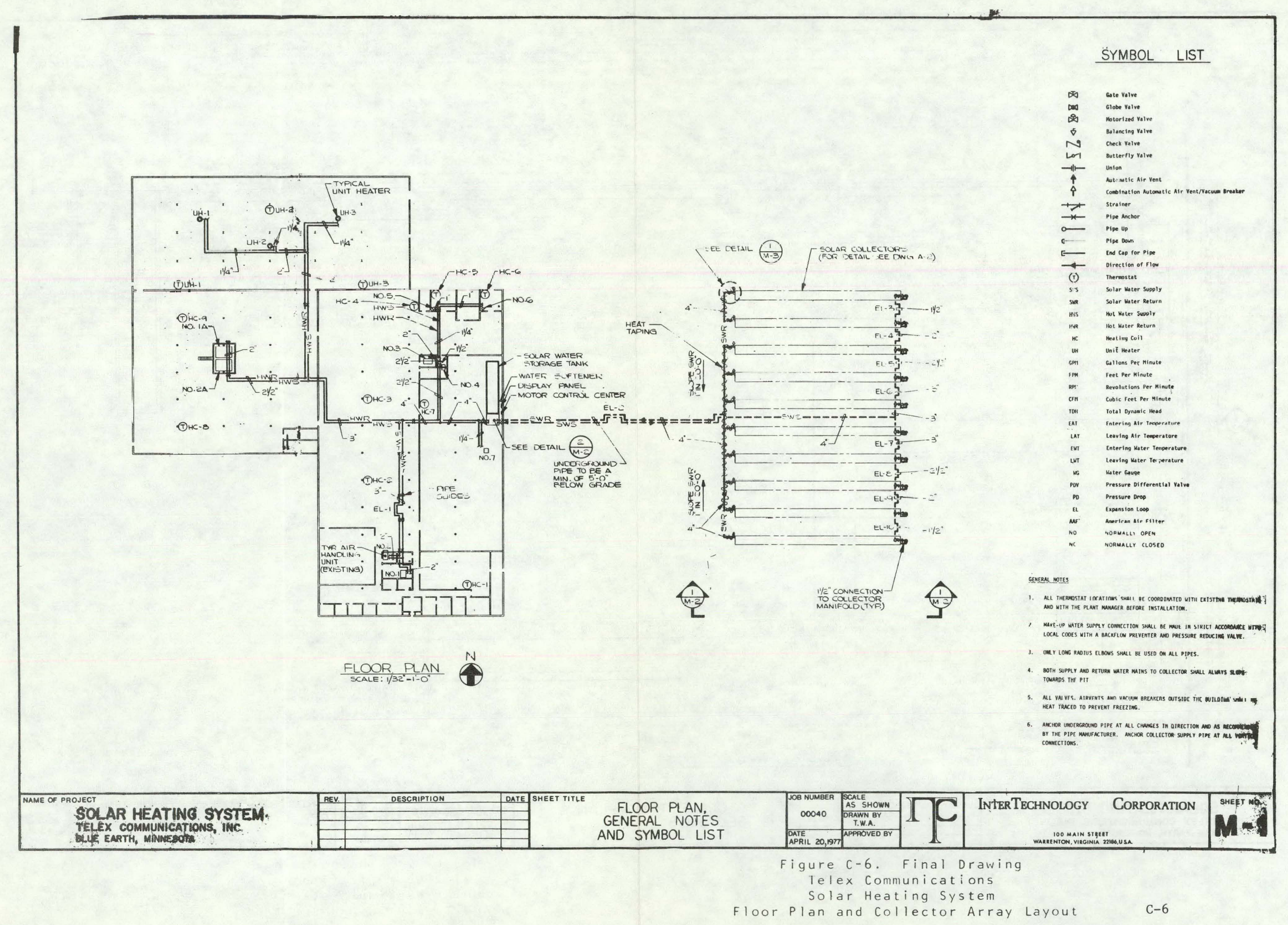




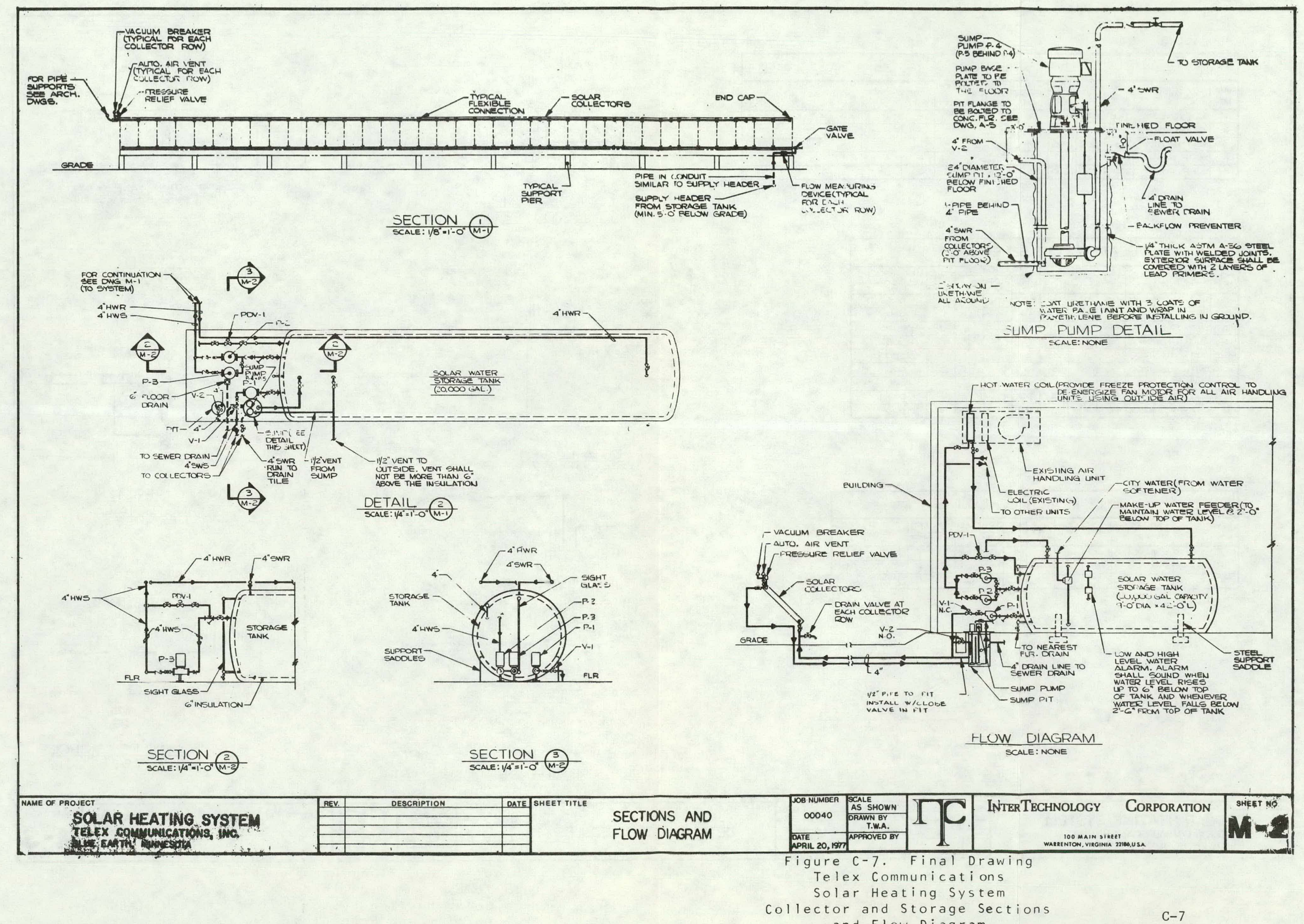

Collector and Storage Sections

and $\mathrm{Flow}$ Diagram 

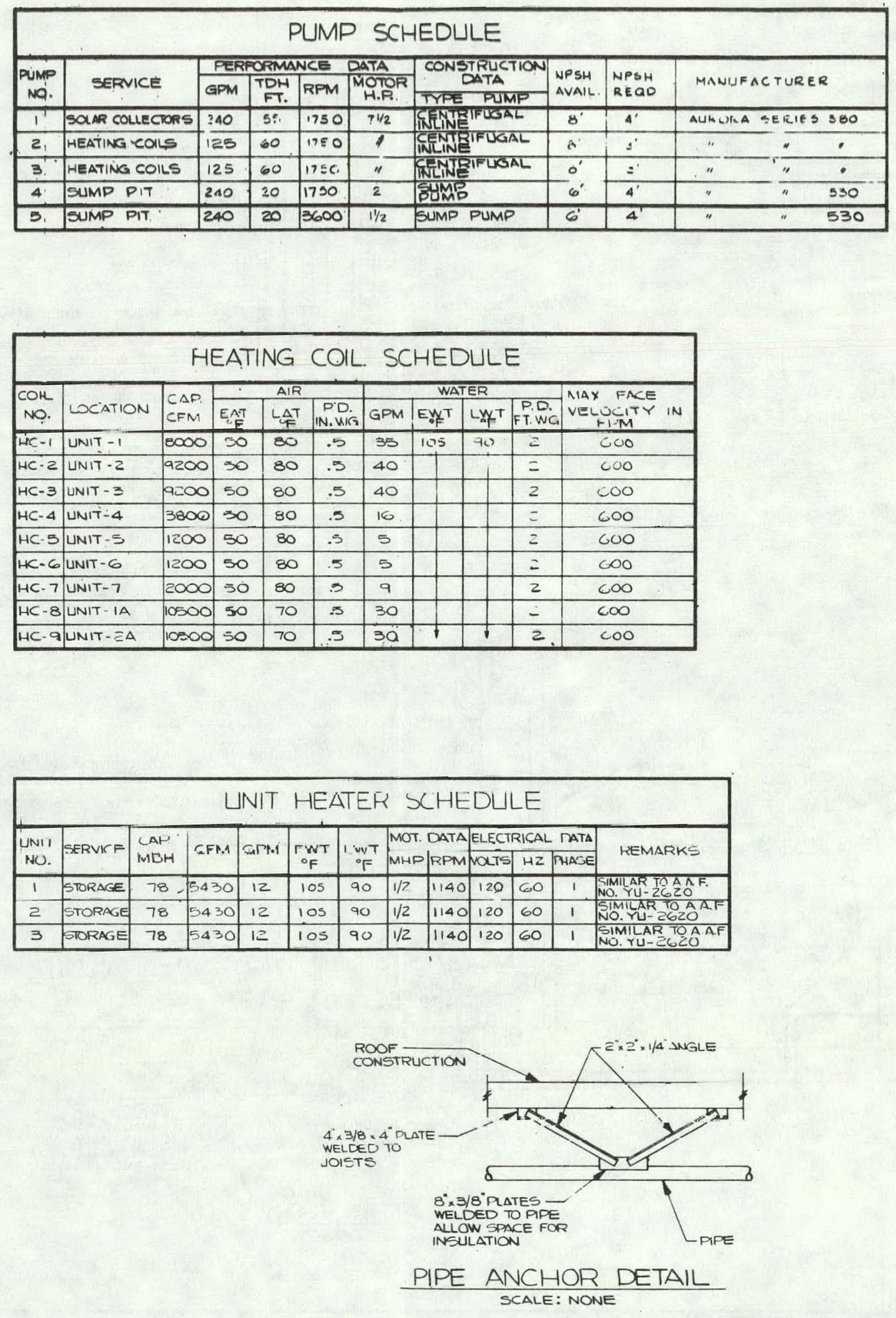

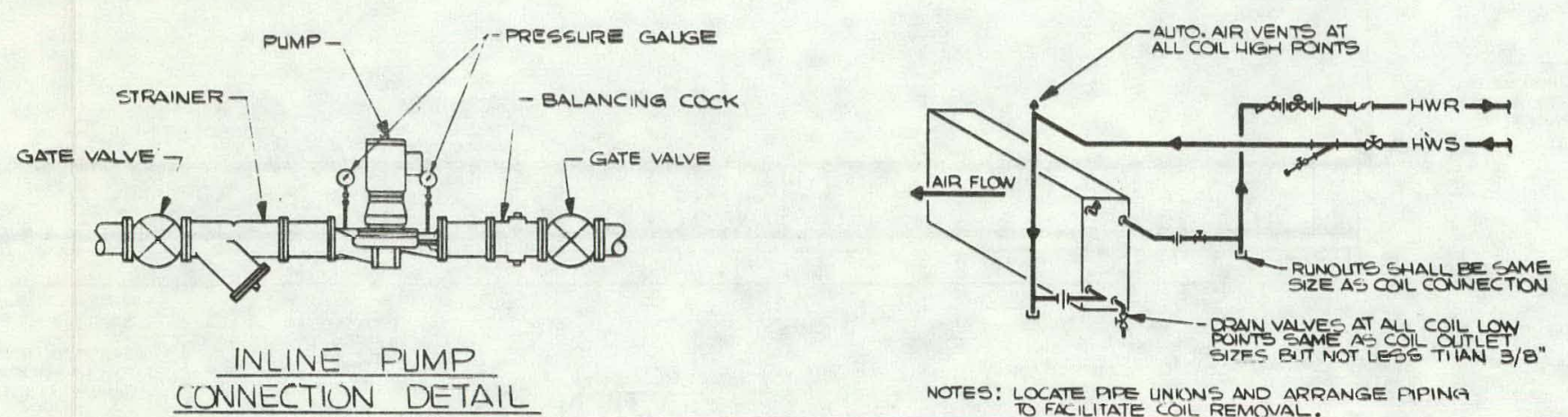

$\frac{\text { CONNECTIUN DETAIL }}{\text { SLALE: NONE }}$
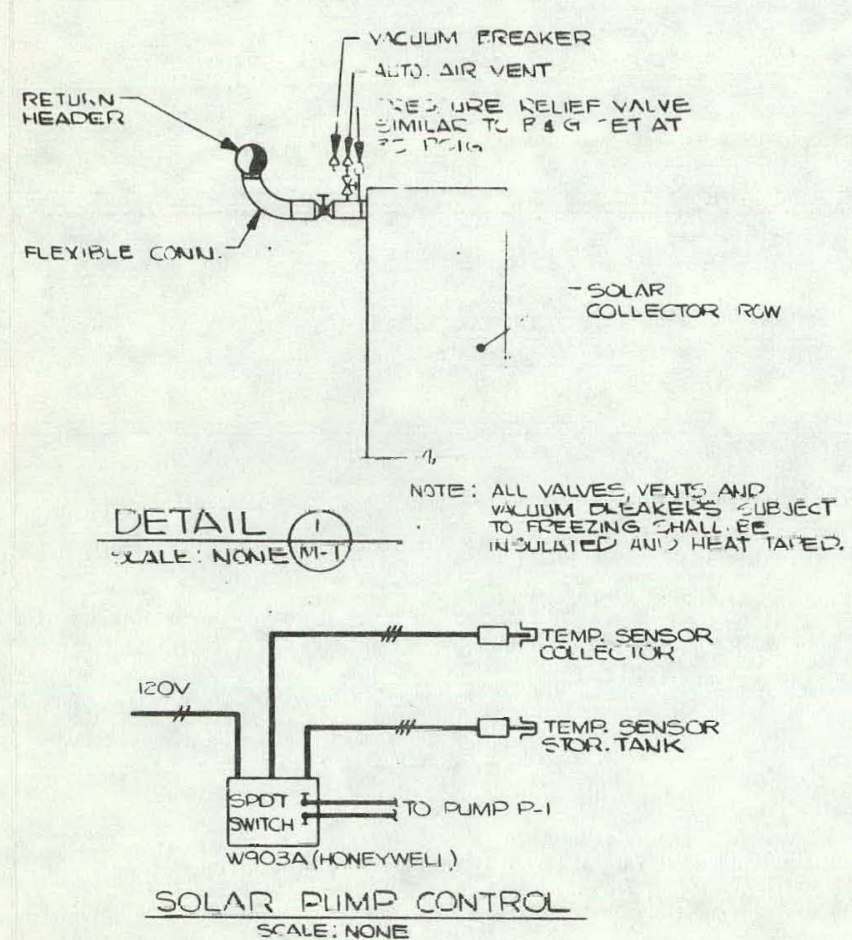

PRESSURE SENSRR
INERETUFN WATERR
MAIN

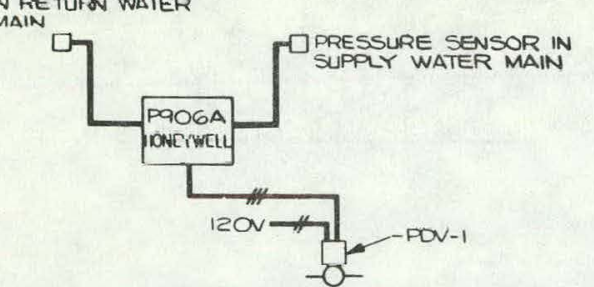

NOTE: LOCATE BOTH SENSORS APPROX, 3/4 OF THE

PRESSURE DIFFERENTIAL VALVE CONTROL
SCALE: NONE

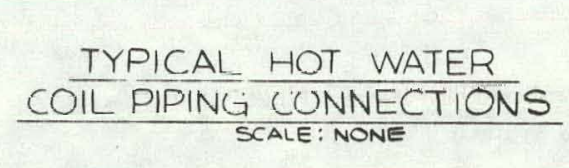

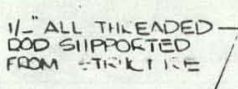

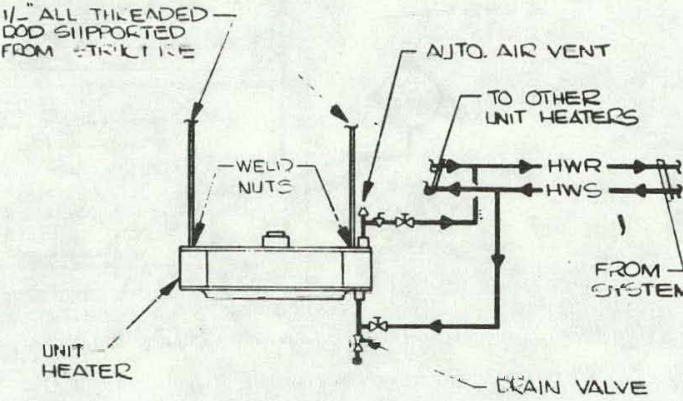

$$
\begin{aligned}
& \text { UNIT HEATER } \\
& \frac{\text { PIFINIC, DETAIL }}{\text { SCALE: NONE }}
\end{aligned}
$$

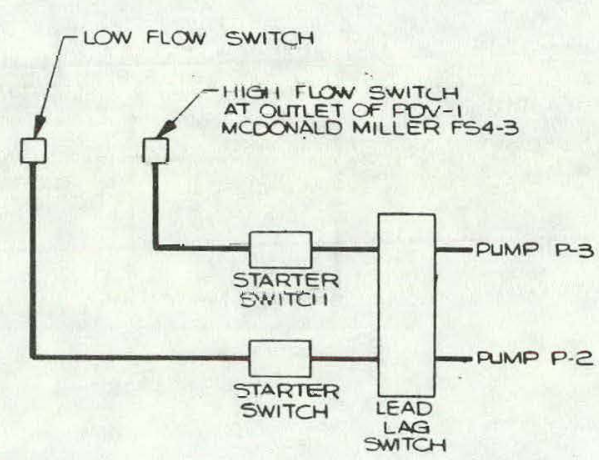

PUMP P-2 AND P-3 CONTROL

\section{NAME OF PROJECT
SOLAR HEATING SYSTEM
TELEX COMMUNICATIONS, ING.}

TLUE EARTH, MINNESOTA

\begin{tabular}{|l|l|l|}
\hline REV. & DESCRIPTION & OATE \\
\hline & SH \\
\hline & & \\
\hline
\end{tabular}

DETAILS AND SCHEDULES

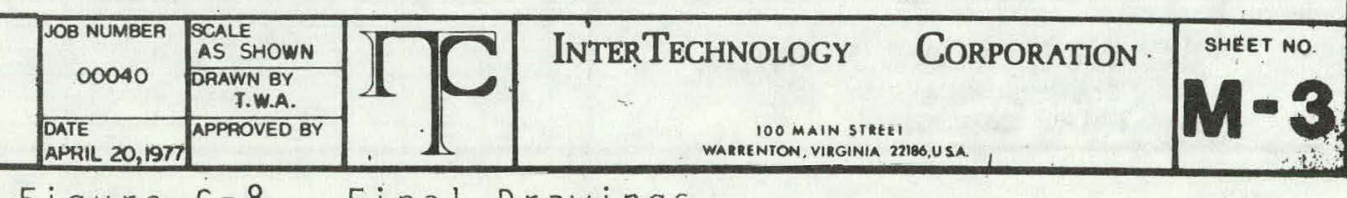

Figure $c-8$. Final Drawings

Telex Communications

Solar Heating System
Details and Schedules 


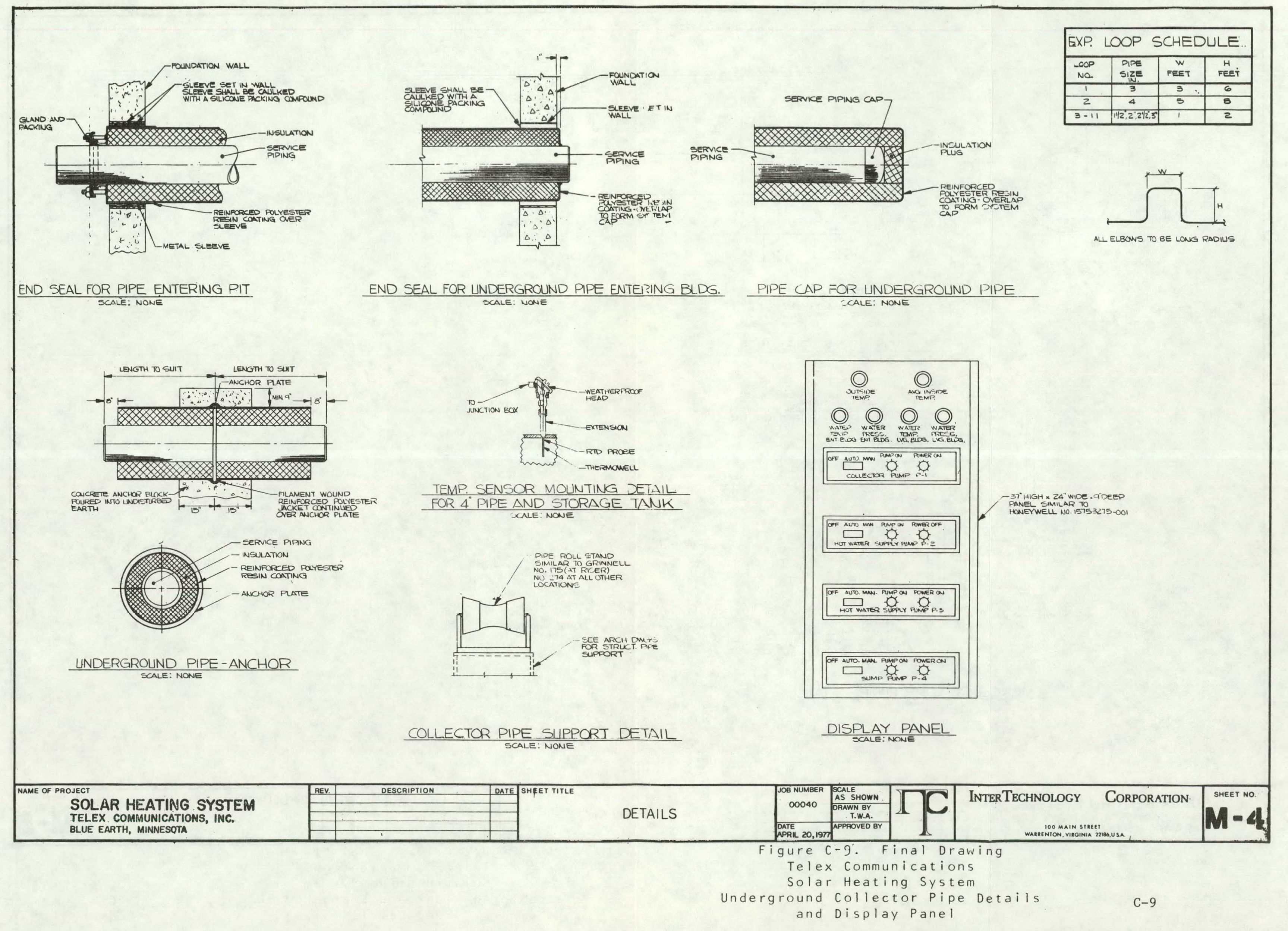



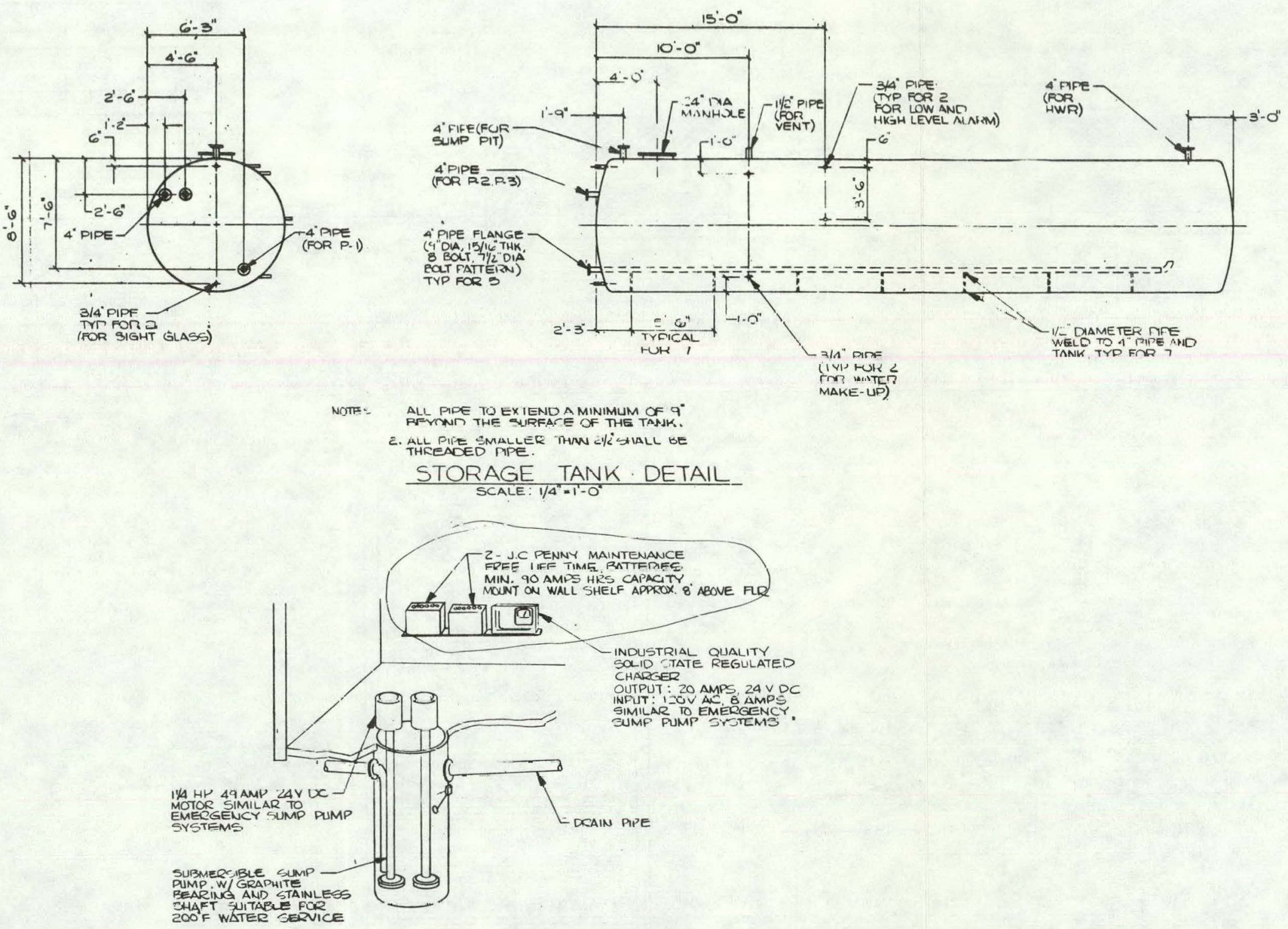

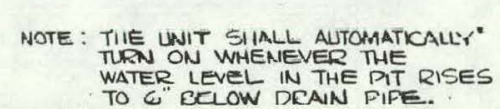

$\frac{\text { ENIERGENCY SUMP. PUMP UEIAIL }}{\text { SCALE: NONF }}$

\section{MME OF PROUECT
SOLAR HEATING SYSTEM
TELEX} TELEX COMMUMICATIONS, IMG.

REV

DESCRIPTION

\begin{tabular}{|l|l|}
\hline DATE \\
\hline
\end{tabular}

\section{DETAILS}

\begin{tabular}{|c|c|c|}
\hline 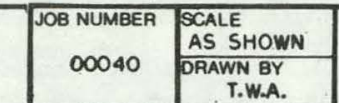 & $\mathbb{D C}$ & IN'TERTECHNOLOGY CORP \\
\hline 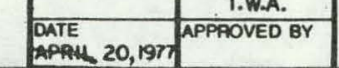 & & 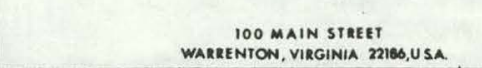 \\
\hline
\end{tabular}

Telex Communications

Storage Tank and Emergency Sump

Pump Details \begin{tabular}{l|l|}
\hline CORPORATION & SHEÉt WQ \\
\hline
\end{tabular} 
APPENDIX D

CONTRACT PRICING PROPOSAL FROM THE INTERTECHNOLOGY CORPORATION PROPOSAL November 26,1975 
APPENDIX D

CONTRACT PRICING PROPOSAL FROM THE

INTERTECHNOLOGY CORPORATION PROPOSAL

November 26,1975

\section{C.1. Cost}

a) Funding Summary

1) Estimated total project cost, including solar energy portion; $\$ 345,050$

2) Estimated total equivalent project cost with conventional energy equipment, so. The project and all conventional equipment is existing.

3) Difference $=$ solar system cost: $\$ 345,050$

4) Payback = solar system cost $\div$ fuel cost savings/year -15.7 years

4.a) If the required instrumentation were not considered the payback period could be reduced to 15 years.

5. Since other costs are involved in the solar system such as design fees, instrumentation, monitoring personnel, and personnel to accompany visitors through the site, the amount of initial cost to the owner (as indicated above) will increase the excecsed payback period. Therefore, it is suggested that the government provice the major portions of the construction monies and the owner will provide the dollars (minus the cost of money to obtain them) equivalent to a payout period of five years. It is understood here that this contract shall be negotiated with the government and that financial ideas expressed herein are not firm but merely. suggestive of the owner's feelings. Future discussions with the proper government agency will define a financially practical and equitable solution. 
THIS PAGE

\section{WAS INTENTIONALLY LEFT BLANK}


This propessal is submitred for ure in connercion with snd in cespunse to lDescribe Rrp.

ERDA PON DSE 75-2

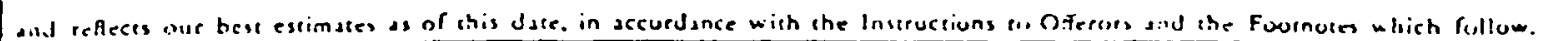

TIPEO NAME ATO TIILE

SICNATURE

NAME OF FIRM

Telex Communications, Inc.

$11 / 26 / 75$

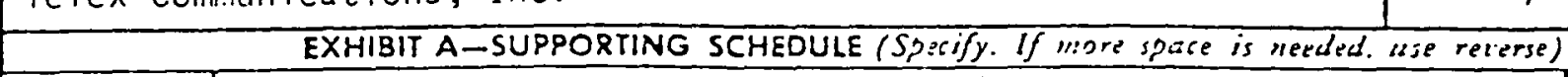

\begin{tabular}{|c|c|c|}
\hline COSTEL NO. & ITEM DESCRIPTION (See fooinote 5) & EST $\operatorname{cost}(3)$ \\
\hline 16 & Solar collectors & 270,000 \\
\hline & Storage tank and insulation & 76,000 \\
\hline & Structural & 25,000 \\
\hline & Pumps & 2,300 \\
\hline & Piping & 16,250 \\
\hline & Controls & 2,500 \\
\hline & Subtotal & 332,050 \\
\hline & Ins Lrunlenlaliuil & $1 J, \cup \cup U$ \\
\hline & Total & 345,050 \\
\hline
\end{tabular}

\begin{tabular}{|l|l|}
\hline & \\
\hline & \\
\hline & \\
\hline & \\
\hline & \\
\hline & \\
\hline & \\
\hline & \\
\hline & \\
\hline & \\
\hline & \\
\hline
\end{tabular}

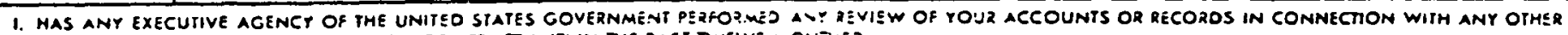
GOVERNMENT PRIME CONIRACT OR SUBCONTRACT WITHIN TME PAST TWE:VE MCNITS?

$\square$ res $\square$ no (If yes. identify bolow.)

HAME ANO ADORESS OF REVIEWING OFFICE AND INOIVIDUAL

TELEPMONE NUMAEZ/EXTENGION

II. WILG YOU REOUIRE THE USSE OF ANY GOVERNMENT PZOPERTY IN THE PERFORMANCE OS THIS PROPOSED CONTRACT?

$\square$ res $\square$ No (If jes. identify on remere or sepurder page)

iII. DO YOU zEOUIRE GOVERMMENT CONTRACT FINANGING IO PERFORM IHIS PROPOSED CONTRACT?

$\square$ res $\square$ no (II yes, identify.): $\square$ adovance payments $\square$ ppogress Payments or $\square$ cuaranteed IOANS

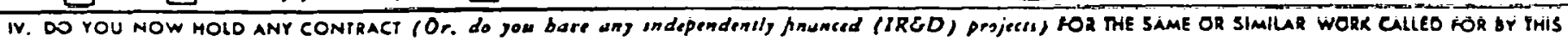
PROPOSED CONTRACT?

$\square$ res $\square$ no (t) ges, idencify.):

V. DOES THIS COST SUMUARY CONFORM WITH THE COST PRINCIPLES SET FORTH IN ACENCY REGULATIONS?

$\square$ res $\square$ no (If no. explwin on rerene or sepurale puge)

See Rereme for Inimecrioni and Fonenores

OPTIONAL. FOKMI $60(10-71)$ 
CONTRACI PRICIISG PROPOSAL

(RESEARCH A.VO DEVELOPAPENT).
O:kice of Hanazement 1 id bu

Aporoval Nio. 2y-h Oly:

This: form is for ux when (i) submistion of cosf or pricing Jao (see FPR $i-3.307-3$ ) is required and (ii) subscicution tor the Uptional Form 59 is autinopied by the conersitinz officer.

VAME OF OFESTOR

InterTechnology Corporation

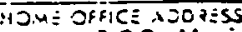

100 Ma in Street

Warrenton, Virginia 22186

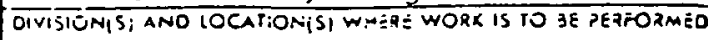

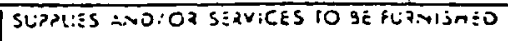

for Telex Communications, Inc.

Feasibility Study, Tradeoff Studies,

Engineering, Construction, Inspection,

Test \& Analysis of System

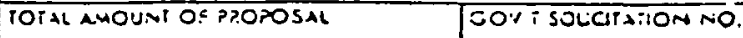

is 28,431

DSE 75-2

\section{DETAIL DESCRIPTION OF COST EIEMENTS}

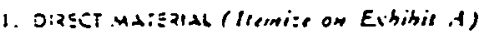

A. PUTEHAJEO PATIS

b. SUzCONTRACTEO ITSMS

c. O:UES-(1) RAW MUTEPAAL

(2) YOUR STANOA2O COMMERCIAL ITENS

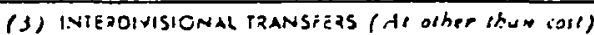

\begin{tabular}{|c|c|c|c|}
\hline 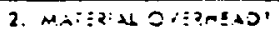 & ifise & $\because$. Is & 6 ie $=$ \\
\hline
\end{tabular}

TOT.L DIPECT .W.TFERIL

J. $0 ! R \equiv C$ U U⿻一 (Sprify)

Feasibility study-tradsoffs, solar enginesinz

onstruction docurents and construction Cost \& Sustem Der formance Analys is

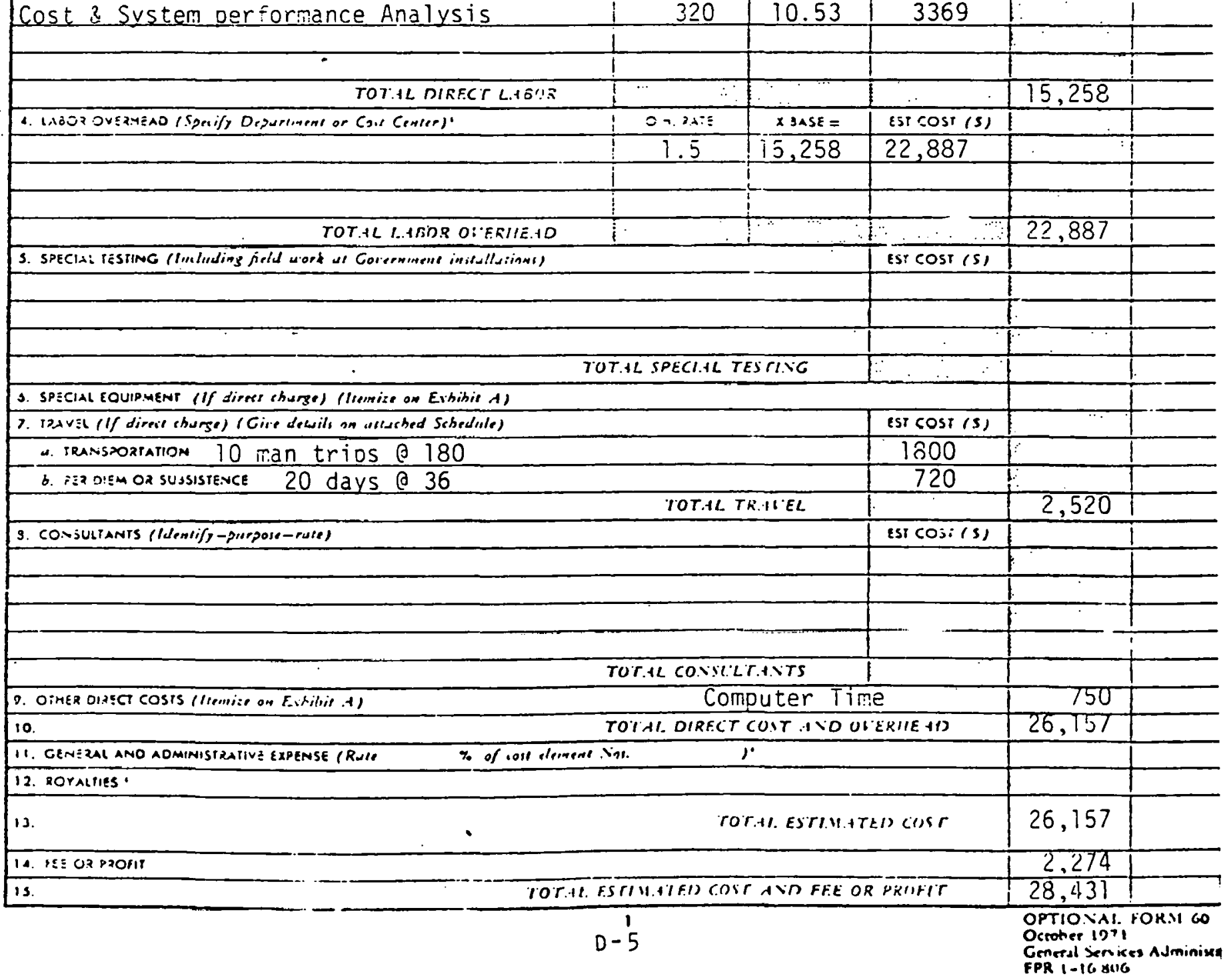




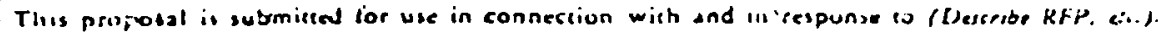

\section{EROA DSE 75-2}

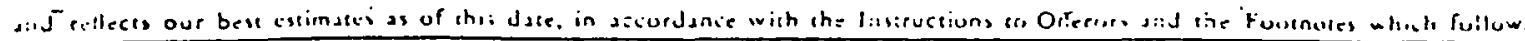

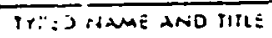
George
C. Szego, President

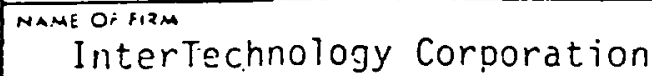
SICNATUZE

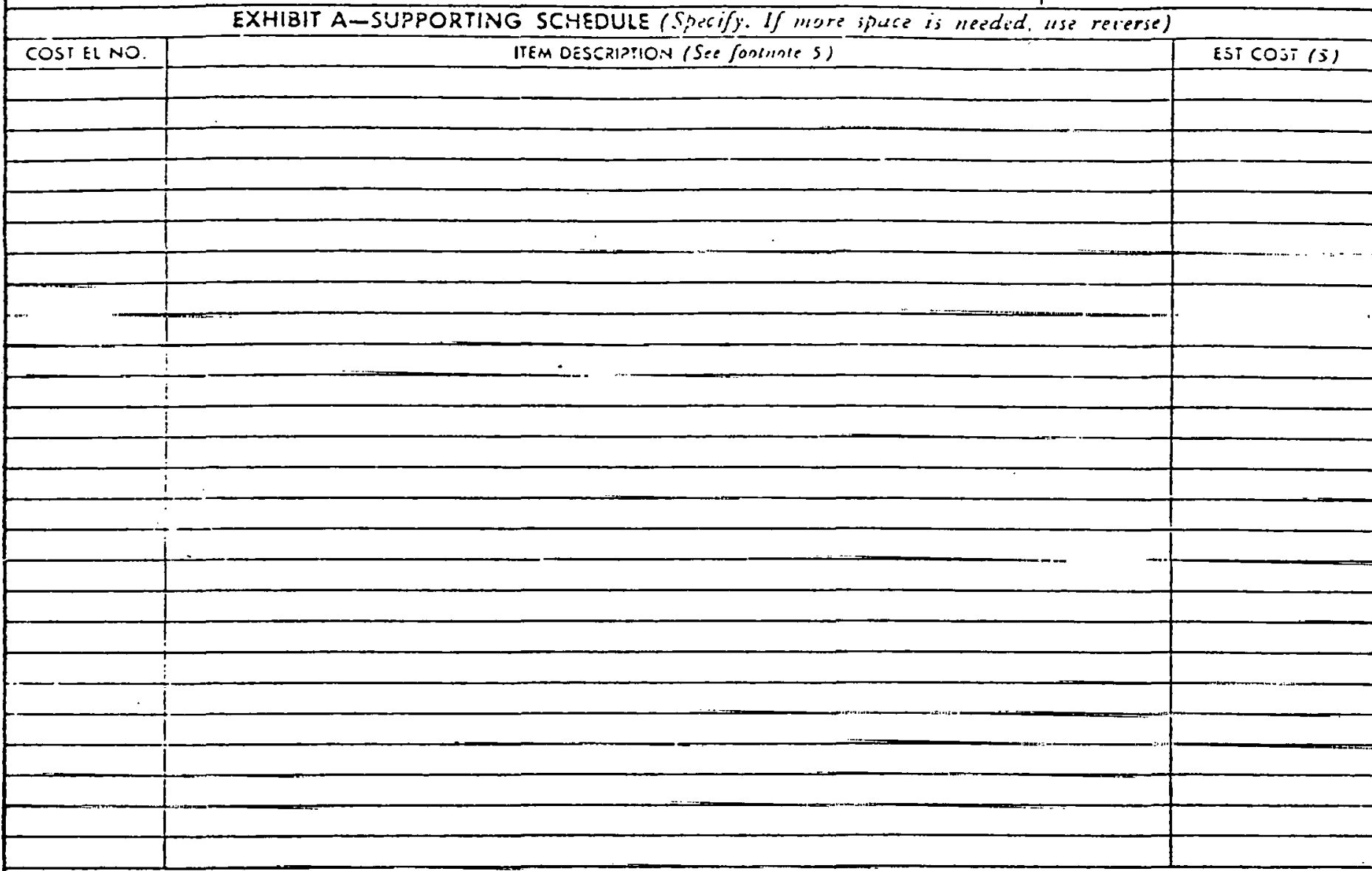

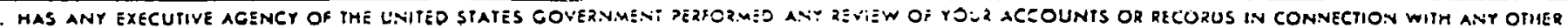
GOVERNMENT PRIME CONTRACT OR SUJCONTRACT WITMIN THE PA5: TW SIVE

$X \mathrm{X}$ YES $\square$ No (If ges. idensiff below.)

NAME AND ADORESS OF REVIEWING OFFICE ANO INUIVIOUAL

J. F. Neury ERDA Washinaton, D.C.

TELEPMONE NUMSER/EXTENSION

II. WIIL YOU REOUIRE THE USE OF ANY COVERNMENT PRDPERTY IN THE PERTOR.MUNEE OE THIS PRDPOSE S CONIZACT?

$\square$ res $R \mathbb{R}$ NO (If ges, identify on reverse or sppurule puge)

iil. DO YOU REOU:RE GOVERMMENT CONTAACT FINANCING IO PERFORM THIS PROPOSEO CONIRACT?

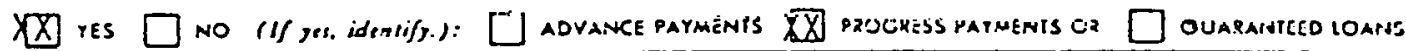

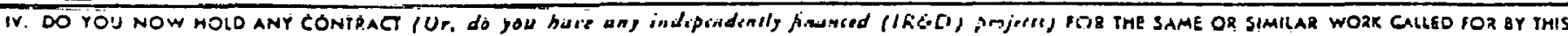
PAOPOSEO CONTRACT?

$\square$ res 28 no (If yes, idenifify.):

Y. DOES THIS COST SUMMARY CONFORM WITH IHE COST PPINCIPLES SET FORIH IN ACENCY RECULAIIOAJ?

$\searrow X$ res $\square$ no (If no. expluin on enterse or sepisesle puge) 


\section{APPENDIX E}

THERMAL PERFORMANCE MODELS

TRNSYS SIMULATION OF ORIGINAL DESIGN OF TELEX COMMUNICATIONS SOLAR SYSTEM

AT BLUE EARTH, MINNESOTA

BY IBM CORPORATION 


\section{APPENDIX E}

THERMAL PERFORMANCE MODELS

TRNSYS SIMULATION OF ORIGINAL DESIGN

OF TELEX COMMUNICATIONS SOLAR SYSTEM

AT BLUE EARTH, MINNESOTA

BY IBM CORPORATION

\subsection{SU'M:ARYY AND CC:ICLUSIOI:S}

$[062-77-1001$

$1 / 5 / 77$

This study was undertaken to assist MSFC in evaluating the ITC croposal to incorporate solar heating in an existing manufacturing building at Blue Earth, Minnesota; specifically, to deterinine the percent soiar coritribution to building heating and to validate the contribution claimed by ITC.

All simulations were made using TRIVSis with MEdison, Wisconsin, design year weather information from the Un: iversity of Wisconsin. Appropriate modifications were made in the temperature profile to match the peak heating season loads given by ITC.

The ITC claim of $79 \%$ appears to be conservative, since IBM results show $90 \%$ (SIM \#1, Table 1) for a comparable situation (no tank mininumi temperature). The primary difference is ir the solur eneroy collected. IBit lised the collector data generated in the University of Connecticut test of the Solar corporation of America collector with a black chrome absorber plate coating. Corresponding data values used by ITC were no: available to IBlA ouring the study.

Solar contribution (as determined by IBM) reduces to $77 \%$ as the ninimum useful tank temperature is increased to $115^{\circ} \mathrm{F}(\operatorname{SIM} \# 3)$; a minimum temperature of $100^{\circ} \mathrm{F}$ produced a solar contribution of $82 \%$. It was also determined that with sufficiently high minimum tank temperatires (e.g., $100^{\circ} \mathrm{F}$ ), only the smal1 (i06 GPM) circulation pump is required. The exact temperature at which the larger pump is required was not determired. Such a determination is beyond the scope of this study. Maxinum solor contribution is obtained with no minimum tank temperature, and, for this situation, both pumps are required. However, it is possible that economic analyses may determine that the extra pump power required may exceed the benefit derived from solar at some minimum temperature and that, therefore, a tank temperature control should be installed. 


\begin{tabular}{|c|c|c|c|c|c|}
\hline & $\begin{array}{l}\text { PIJR } \\
\text { AIVALYSIS } \\
\text { UPDATE }\end{array}$ & $\begin{array}{l}\text { TRNSYS } \\
\text { SIN } \# 1\end{array}$ & $\begin{array}{l}\text { TRASYS } \\
\text { SIM H2 }\end{array}$ & $\begin{array}{l}\text { TRNSYS } \\
\text { SIM } \# 3\end{array}$ & \\
\hline $\begin{array}{l}\text { Tank Minimum Temperature Cutoff Level } \\
\text { Solar Energy Available } \\
\text { Solar Energy Collected } \\
\text { Collector Efficiency } \\
\text { Heating Load } \\
\text { Solar Energy Applied to Heating } \\
\text { Auxiliary Energy Required } \\
\text { Heat Lost Due to Tank Over Temperature } \\
\text { Average Storage Tenperature } \\
\text { Tank Loss. } \\
\text { Percent Solar }\end{array}$ & $\begin{array}{l}\text { Hone } \\
\cdots(81.5)^{\star} \\
\cdots-. . .- \\
15.8 \\
12.5 \\
3.3 \\
0.5(2.8) \\
\cdots(28) \\
\cdots(.308) \\
79\end{array}$ & $\begin{array}{l}\text { lione } \\
53.0(77.6) \\
16.7(20.0) \\
31.6(25.8) \\
17.3 \\
15.7 \\
1.7 \\
1.1(4.1) \\
52.6(66.7) \\
.143(.266) \\
90\end{array}$ & 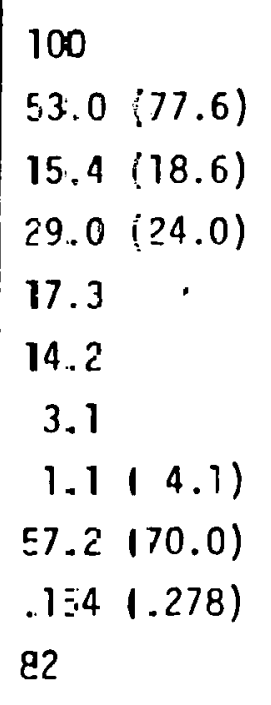 & $\begin{array}{l}115 \\
53.0(77.6) \\
14.4(17.7) \\
27.3(22.7) \\
17.3 \\
13.3 \\
4.1 \\
1.1(4.1) \\
60.8(72.5) \\
.163(.287) \\
77\end{array}$ & $\begin{array}{l}{ }^{\circ} \mathrm{F} \\
10^{8} \mathrm{KJ} \\
10^{8} \mathrm{KJ} \\
\% \\
10^{8} \mathrm{KJ} \\
10^{8} \mathrm{K.J} \\
10^{\circ} \mathrm{KJ} \\
10^{8} \mathrm{KJ} \\
{ }^{\circ} \mathrm{C} \\
10^{8} \mathrm{KJ} \\
\%\end{array}$ \\
\hline
\end{tabular}

* Parenthetical values represent 12 nonth values; .11 others represent September throl.gh April values.

Table 1. Talex Buildinc Salar System Performance Analysis Summary 
Manual startup and shutdown of the olar heating system is planned for the beginning and end of the heating season. Such an operational mode leaves heating during spring and fall transition periods to the auxiliary systen. IBM recommends that an economic analysis of control and operational costs of alternative operational modes be made for (1) leaving the circulation pump on year-round, (2) automatic control of circulation pump when heating load present, and (3) manual control during heating season (current system).

A potential collector pump oscillation problem should also be investigated. IBM was unable to determine the location of the temperature probes of the pump differential controller. Depending on the specific locations, the pump "on" and "off" criteria may be incompatible; i.e., marginai insolation and ambient temperature conditions sufficient to start the pump may be insufficient to continue its operation, resulting in an oscillation. The exact locations should be determined and controller setpoints determined for non-oscillatory operation. 


\subsection{ASSLMPTIONS AND RATIONALE}

This section details the assumptions and approximations made in modeling the Telex solar system and the rationale behind each. Assumptions are divided into three categories below: (1) Weather and Loads; (2) System; and (3) Controls.

\subsection{WEATHER. AND LOADS}

Weather data (including insolation) used was derived from the University of Wiscons in design year for Madison, Wisconsin. Insolation at Madison and Blue Earth. Minnesota, is approximately the same according to Eennett's graphical data. This is further supported by the "solar energy available" data in Table 1, where the annual values differ by approximately $5 \%$.

Temperatures at Madison were significantly altered (by $3.67 c^{\circ}$ 10wer) in order to better match heating loads in the peak heating season of December through February. As a consequence, heating loads (by following the Madison seasonal variation) are modeled larger than the ITC model during the months of ilarch and April. Heating loads were assumed to be zero from May 1 through August 28. The IBP approximation produces a larger total load than ITC (by $9 \%$ ), but this results in a more conservative estimate while still providing good agreement in high load periods.

The load dependence on ambient temperature is shown in figure 1 . It was derived by plotting the Septemter through April monthly load data given in the ITC analysis of $9 / 22 / 76$ against Rochester, Ninnesota, ambient temperatures and fitting a straight line to the points. The load function implies that heat is required if the ambient temperature is less than $20.38^{\circ} \mathrm{C}\left(68.7^{\circ} \mathrm{F}\right)$ and that the overall loss coefficient of the building is $13847 \mathrm{~kJ} / \mathrm{hr}-\mathrm{C}^{\circ}$. This setpoint differs from the setpoints given by ITC $\left(65^{\circ} \mathrm{F}, 55^{\circ} \mathrm{F}\right.$, and $50^{\circ} \mathrm{F}$ in the various zones) but produces the same heating loads. A single zone was used in the TRINSS model since no finer-resolution load data was available. Likewise, no economizers or night setback thermostats were modeled.

Bennett, Iven. "Monthly Maps of Mean Daily Insclation for the United States", Solar Erergy, 9 (3): 145-158 
HEATING LOAD VS. $\left(65^{\circ} \mathrm{F}-T_{\text {AVG }}\right)$ FOR ROCHESTER, MINN.

FROM $09 / 22 / 76$ DATA

TELEX BUILDING

BLUE EARTH, MINN.

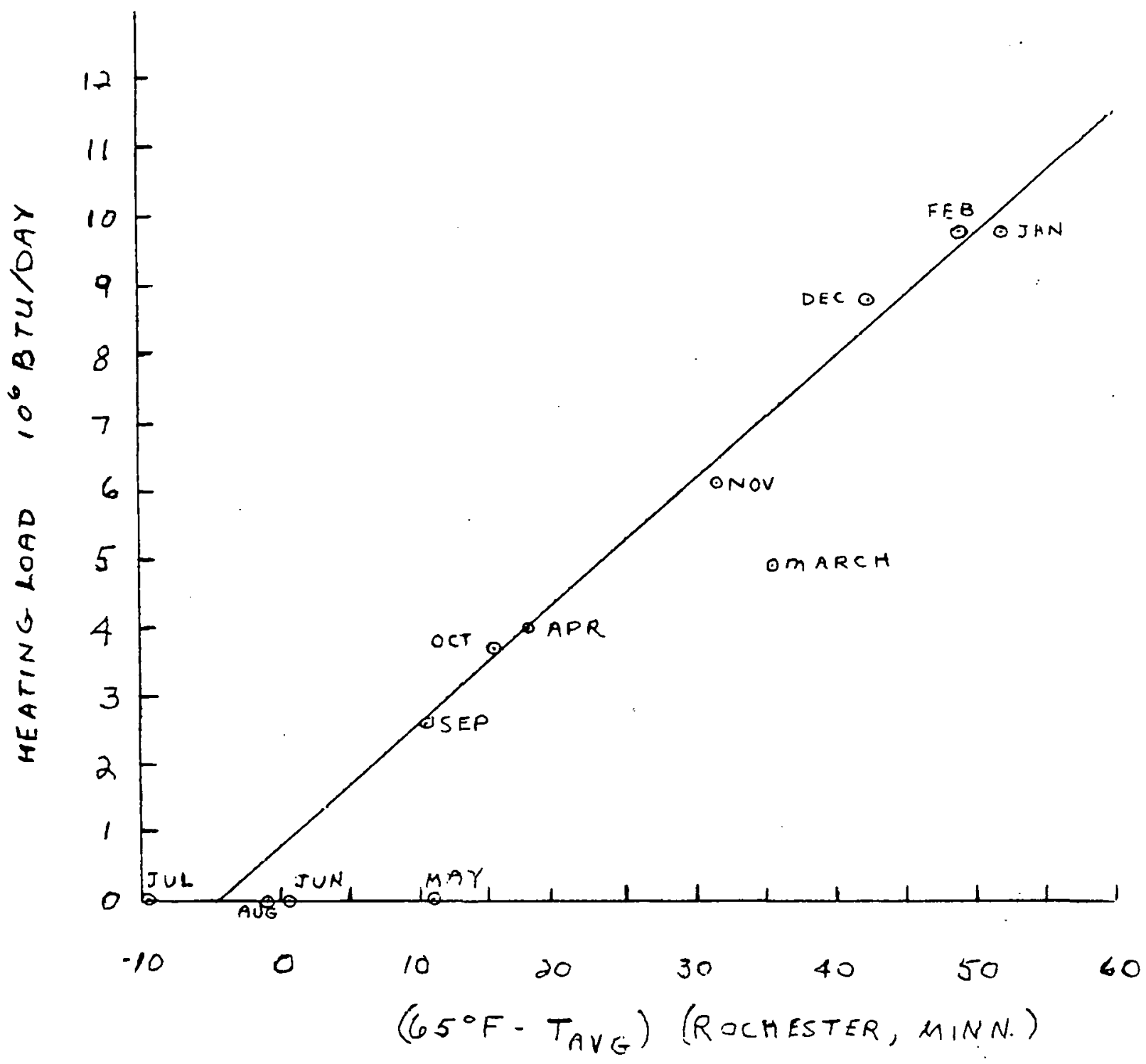

FIGURE 2. HEATING LOAD YS. AMBIENT TEMPERATURE

$E-5$ 


\subsection{SYSTEH}

The present storage tank design is one of 29,796 gallons capacity filled to 23,000 gallons. As a simulation artifice, a 23,000 gallon tank with the same wetted area was chosen for the model to provide a full tank with the same energy loss rate. The tank was assumed to be isothermal. As a first approximation, the tank environment was chosen as the annual average temperature at Rochester $\left(6^{\circ} \mathrm{C}, 42.8^{\circ} \mathrm{F}\right)$. Tank temperature was limited to $99^{\circ} \mathrm{C}$ due to the large atmespheric vent on it and the $1000 \mathrm{ft}$. elevation of Elue Earth. Energy lost due to hoiling was tracked and is shown in Table 1.

Tank-to-buildirg piping was assumed lossless in the model, since a supplementa? analysis showed that less than $0.2 \%$ of the usable energy collected is lost in the piping.

The auxiliary resistance heating capacity was chosen to meet the building loss at the ASHRAE $21 / 2 \%$ Rochester temperature $\left(-25^{\circ} \mathrm{C}\right)$. Since this system currently meets the entire heating load, its capacity is always sufficiert to supplement the solar contribution to $100 \%$ of the load, and its exact capacity is thus not significant to the model. The value chosen is $625,000 \mathrm{KJ} / \mathrm{hr}$.

The heat transfer coefficient of the duct heat exchangers was determined from inlet and outlet temperatures and flow rates given in the mechanical drawings. Assuming a crossflo: heat exchanger, the effectiveness was determined to be 0.55 , which implies a UA of $129,566 \mathrm{~kJ} / \mathrm{hr}-\mathrm{C}^{\circ}$ at the rated conditions. Given this, the model computed effectiveness for all other flow conditions.

Building capacitance vas chosen to be $450,000 \mathrm{KJ} / \mathrm{C}^{\circ}$ to provide a stable simulation with a step size of 0.25 hour. That is, maximum solar combined with auxiliary heat was not sufficierit to cause a building temperature rise of more than $2 \mathrm{C}^{\circ} / \mathrm{hr}$ or $0.5 \mathrm{C}^{\circ} / \mathrm{step}$. In this way, the simulation could not "skip over" a control regime in one time step, and simulation statilitiy vas enhanced.

Building temperature was 1 imited to $25.56^{\circ} \mathrm{C}\left(78^{\circ} \mathrm{F}\right)$ to simulate the eiffects of the cooling system. No energy penalty was assessed for this. 


\subsection{CONTROLS}

The load profile (Figure 2 ) is equivalent to a heating setpoint of $20.38^{\circ} \mathrm{C}$ $\left(6 E .7^{\circ} \mathrm{F}\right)$. Therefore, the first stage heating (solar) is selected when the building temperature falls below that point. Second stage (auxiliary) heating is selected when the building temperature falls $10^{\circ}\left(1.8 \mathrm{r}^{\circ}\right)$ belcir the first stage setpoint; however, solar heating is also continued. The second stage setpoint is $19.38^{\circ} \mathrm{C}\left(66.9^{\circ} \mathrm{F}\right)$.

Selection of the tank to heat exchanger flow rate in the real system is a trial-anc-error function, which may step through several flow rates before deternining the proper one. This produces transients in flow and temperature distribution which do not occur in the model. The model instantaneously selects the minimum flow rate (of the set 106, 154 or $260 \mathrm{GPM}$ ) which meets the heating load.

Collector flow logic in the real system is maintained at the last selected state (OFF or Oii) for 10 minutes before another switch is allowed. The simulation models this as 15 minutes (one step size) in order to simplifiy the model logic. This makes a minimal difference over a year sinulation since, in general, the collector comes on once per day and goes off once per day.

A tank minimum temperature cutoff for the heat exchanger flow wis modeled in the simulation. At the time the study was performed, some consideration was beins given to such a control in the real syster. In addition, ITC studies assumed a $100^{\circ} \mathrm{F}$ minimum, altlough, apparently, no control logic was used to enforce it. In order to assess the impact of such a control, it was left as a study parameter, and Table 1 indicates the effects of its variation. 
IBM ANALYSIS

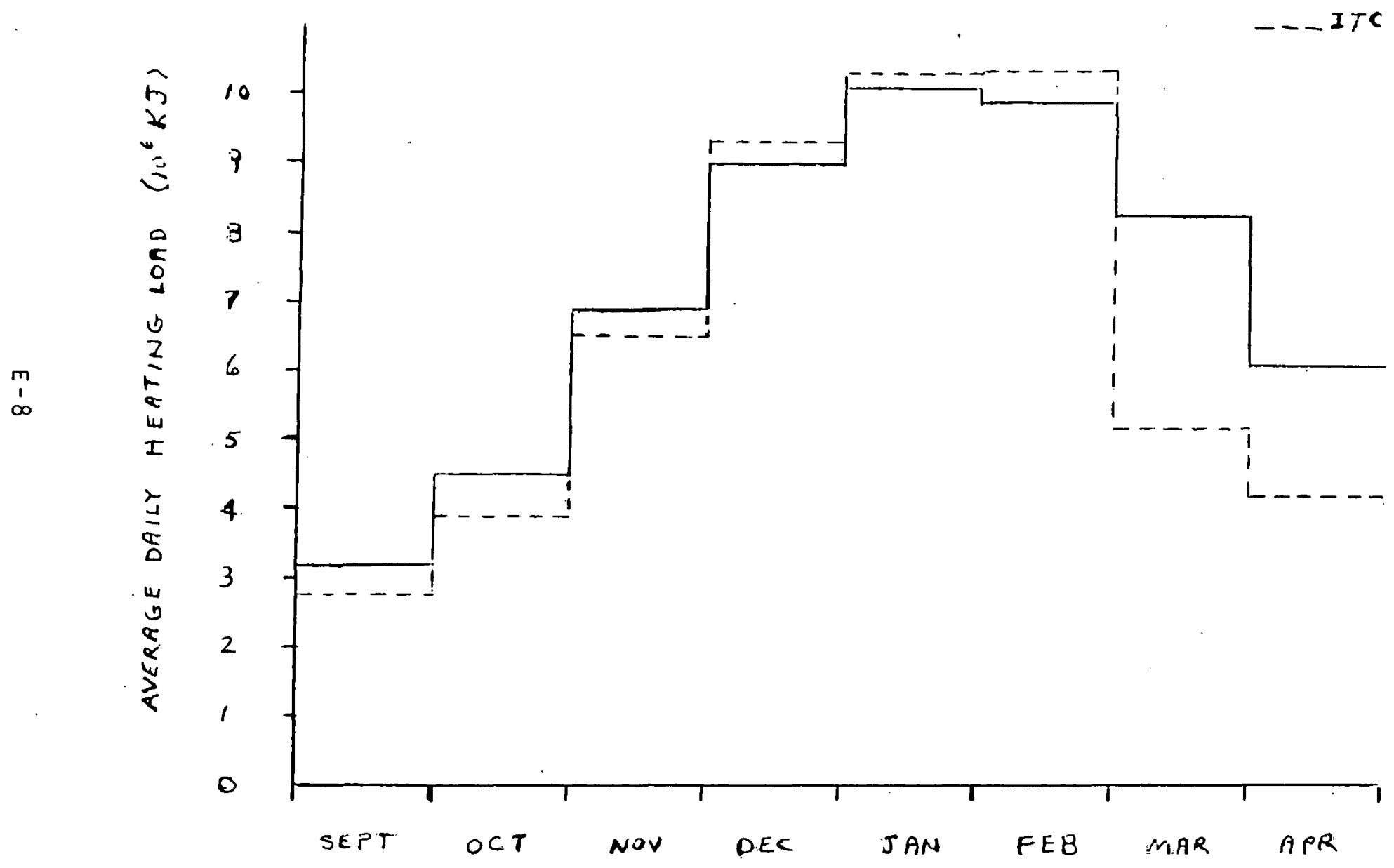

FIGURE A. HEATING LOAD COMPARISON 
TRHSYS MODEL DESCRIPTIO:-

\section{A.0 INTROOUCTION}

The TRNSYS model used in this Telex study is shown in scheriatic form in Figure A-1. Water heated by the collector is pumped into a storage tarik when the collector/tank temiperature difference is greater than $5^{\circ} \mathrm{F}$. Flow continues until the difference is ?ess thar. $2^{\circ} \mathrm{F}$. A relief valve limits the tank temperature to less thail $610^{\circ} \mathrm{F}$. When a heating load is present, water is pumped from the tank into a water/air duct heat exchanger at one of three flow rates $\{106,154$ or $260 \mathrm{GPF}$; dependent on the amount of heating required. The fan circulates air through the duct heat exchanger across the auxiliary resistance heating and through the building. First stage heating from the solar sto:age tank is activated at $68.7^{\circ} \mathrm{F}$; second stage heating from the auxiliary, at $66.9^{\circ} \mathrm{F}$. Since a heating load was available orily for a single zone, the building was treated as a single zone with a single composite duct heat exchanger, fan and auxiliary heat scurce.

The model used in this study is shown in information flow form in Figure A-2. Each unit in the simulation is grouped into a loop and discussed belcw. Solution order of the urits is indicated in the figure by the numbers on the left side of each unit.

\section{A. 1 HEATING LOAD PROFILE}

Units 12 and 16 generate the heating load. Unit 12 is a building model with a capacitance of $450,000 \mathrm{~kJ} / \mathrm{C}^{\circ}$, a heat loss coefficient of $13847 \mathrm{~kJ} / \mathrm{hr}-\mathrm{C}^{\circ}$ and no internal heat gain. The heating load is given by the equation

$$
O_{H}=13847 \frac{K J}{A r-C^{\circ}}\left(20.38^{\circ} \mathrm{C}-T_{A}\right)
$$

where $T_{A}$ is the external ambient temperature. Unit 16 prevents summer room overheating by simulating cooling at a level of $25.56^{\circ} \mathrm{C}\left(78^{\circ} \mathrm{F}\right)$. Energy required for this is not accounted in the heating system. 


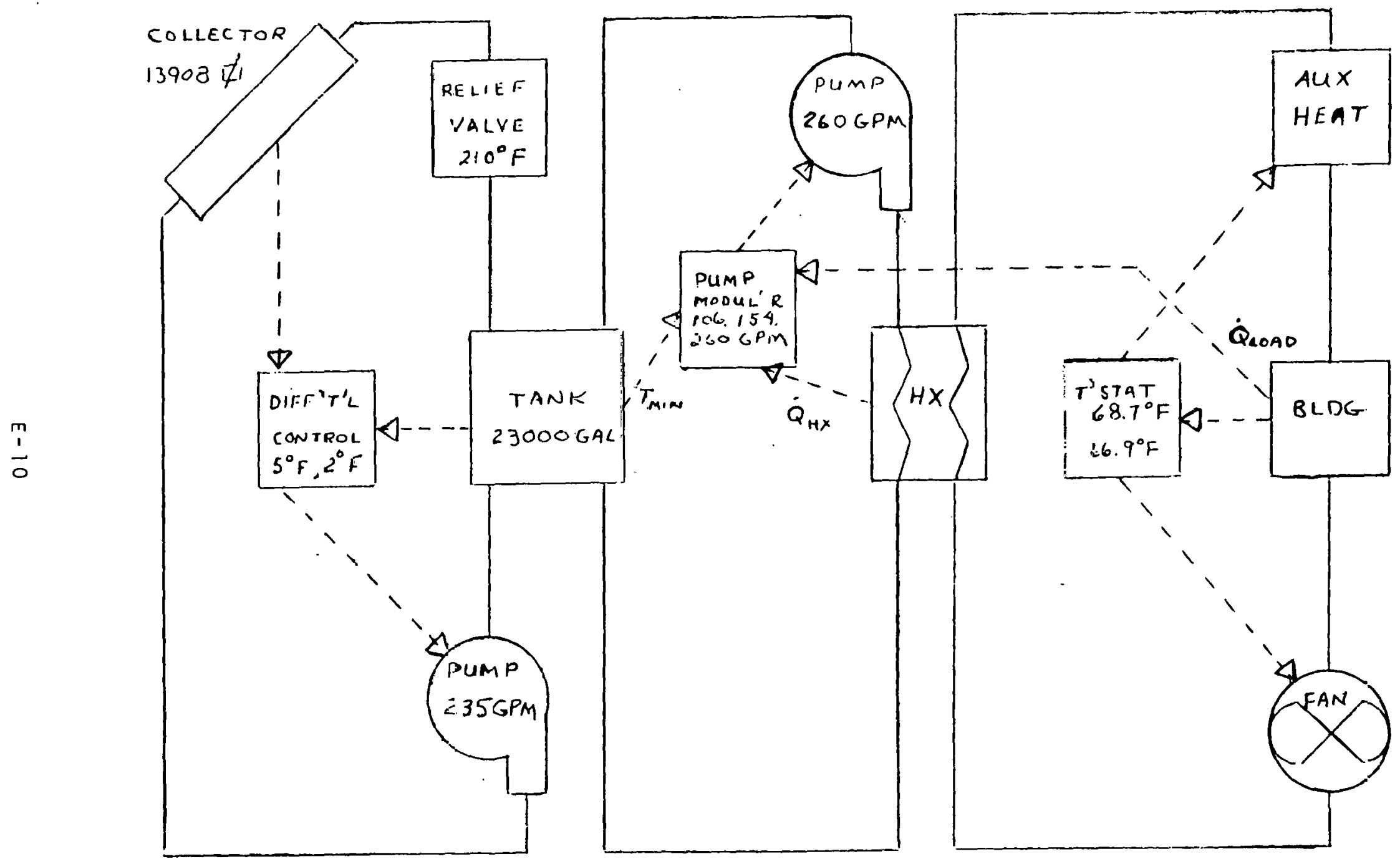




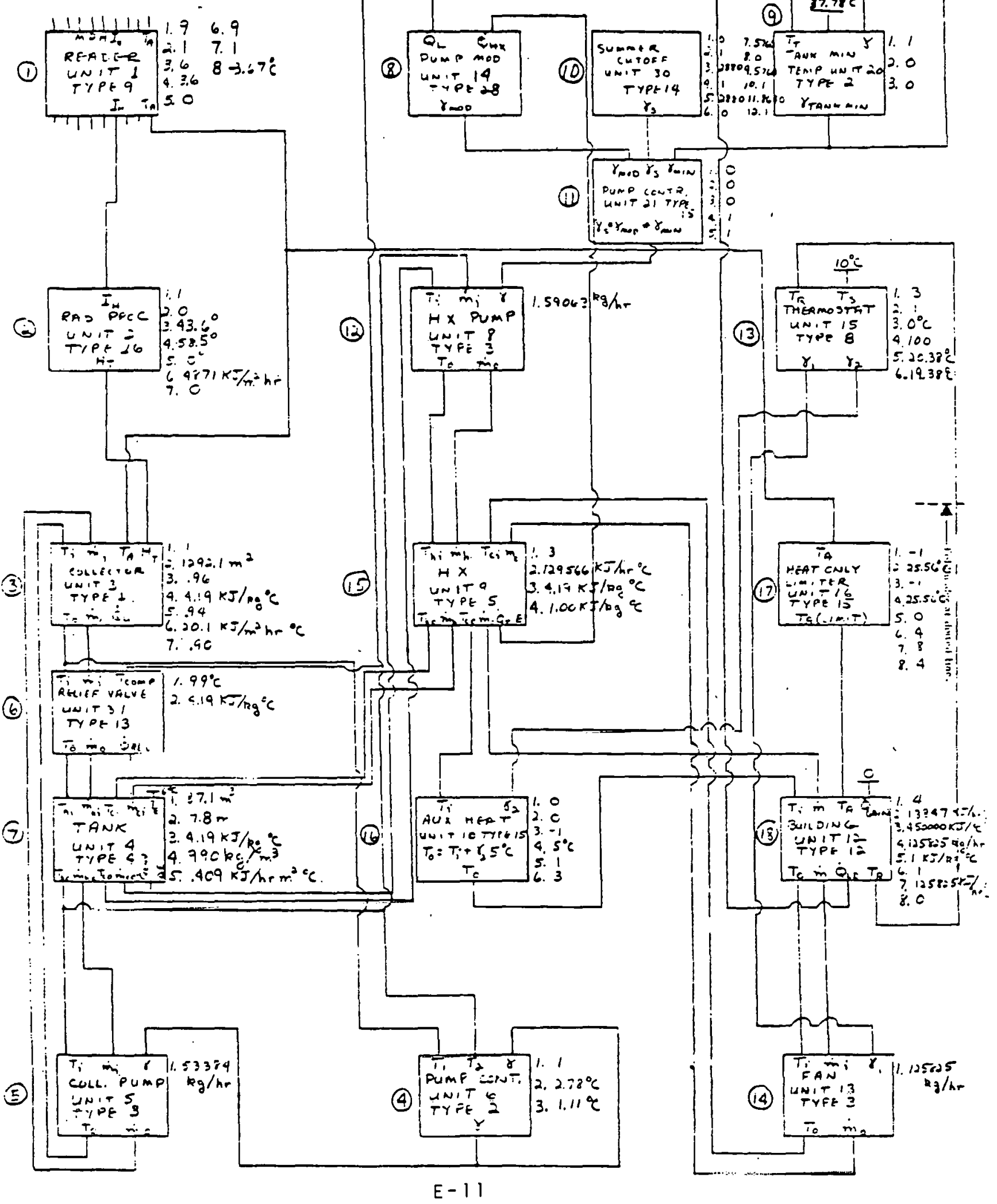




\section{A.2 COLLECTOR LOOP AINO CONTROL}

Units 1, 2, 3, 5, 6 and 31 comprise the collector loop and its ccritrol. Unit 1 reads design year weether data from Madison, Wisconsin, anc reduces the ambient temperature by $3.67 \mathrm{C}^{\circ}\left(6.61 \mathrm{~F}^{\circ}\right)$ to approximate Bive Earth, Minnesota, weather. Unit 2 transforms horizontal insolation data to that incident on a collector facing due south at a latitude of $43.6^{\circ}:$ and tilted at $58.5^{\circ}$ to the horizontal. The collectors (Unit 3 ) use water as a heat trarisfer medium and are modeled with en efficiency factor $\left(F^{\prime}\right)$ of 0.96 , a loss coefficient $\left(l_{L}\right)$ of $20.1 \mathrm{~kJ} / \mathrm{m}^{2}-\mathrm{hr}-\mathrm{c}^{\circ}$, an absorptance $(a)$ of 0.94 , and a cover transmittanice $(\tau)$ of 0.90 . The total collector array area is $120 \mathrm{z} .1 \mathrm{~m}^{2}$. The collector pump (Unit 5) has a capacity of $53384 \mathrm{~kg} / \mathrm{hr}$ (235 GPM) and is controlled by Unit 6 . The pump is activated if the temperature differential between the collector outlet and the storage tank is greater than $2.780^{\circ}\left(5 F^{\circ}\right)$. Subsequent deactivation occurs when the differential falls below $1.11 \mathrm{C}^{\circ}\left(2 \mathrm{~F}^{\circ}\right)$. The mininum activation/deactivation time interval is 15 minutes. A relief valve (init 31 ) is placed in the loop to limit simulated tank temperatures to boiling at $100 \mathrm{ft}$. altitude $\left(00^{\circ} \mathrm{C}, 210.2^{\circ} \mathrm{F}\right)$. Hater in the collector flow:s through hot storage to cumpiete the loop.

\section{A.3 HOT STORAGE}

Urit 4 mudels a water-filled, $87.1 \mathrm{~m}^{3}$ (23,000 gallon) tank with a heigh: of $7.8 \mathrm{~m}$. The heat $10: 5$ coefficient is $0.409 \mathrm{~kJ} / \mathrm{r}_{\mathrm{r}}-\mathrm{mr}^{2}-\mathrm{C}^{\circ}$. It is assuried to be an isotherrial (fully-mixed) tank in a constant anibient temperature of $6^{\circ} \mathrm{C}$ $\left(42.8^{\circ} \mathrm{F}\right)$. The simulation recuires that the tank be full; thus the riodeled dimensions are difterent trori the actuai tank dimensions (a capacity of $29,7 \pm 6$ gallons). The modeled tank has a capacity of $2 j, 000$ gallons and the same wetted surface area as the actual tank.

\section{A.4 HELTTHG LOOP}

The heatirn loop consists of a water loop (Units $8,9, i 4,20,21$ and 30 ) and an air loop (Units 10,13 and 15). The water loop plimps water from the hot storage tarik (Unit 4) through a duct heat exchanger (Unit 9) arid tack via a pump (Unit 8) niodulatable to levels of 105, 154, and $260 \mathrm{GPM}$. 
The air loup blows air throuch the ' sat exchanger (Unit 9) across auxiliary resistance heating (Unit 10), throu.h the building (Unit 12) ane back via a corposite fan (Urit 13) with $125825 \mathrm{~kg} / \mathrm{hr}$ capacity. Operation of this is under control of a two-stage thermostat (Unit 15).

In the water loop, the heat exchanger is crossflow water/air with an overall heat transfer coefficient of $129566 \mathrm{~kJ} / \mathrm{hr}-\mathrm{C}^{\circ}$. Pump control is by three logical functions: (1) minimum tank temperature (Unit 20); (2) heating load requirement modulator (Lnit 14); and (3) sumiser cutoff (Unit 30). These three functions are All'ed by Unit 21 to provide a finil modulated pump control sigrial. The mininum tank tamperature control disables the punp if the tank temperature falls belol: the set point (values of $0^{\circ} \mathrm{C}\left(32^{\circ} \mathrm{F}\right), 13.38^{\circ} \mathrm{C}\left(06.88^{\circ} \mathrm{F}\right), 37.78^{\circ} \mathrm{C}$ $\left(100^{\circ} \mathrm{F}\right)$, and $4 E .11^{\circ} \mathrm{C}\left(115^{\circ} \mathrm{F}\right)$ were used as stucy parameters). The moduictor selects the mininium flow rate necessary to meet the heating load via the heat exchanger; it selects full or: if all rates are insufficient. During the 120 day period from May 1 through August 28 , the summer cutoff disables the pump coripletely.

In the air lcop, tha auxiliary heater is sized to provide a $50^{\circ}$ tempercture rise in the absence of solar assist at the ASHRAE $21 / 2 \%$ temperatcre for Rochester, Ninnesota $\left(-25^{\circ} \mathrm{C}\right)$. This is supplied by a heater capacity of $629125 / \mathrm{kJ} / \mathrm{hr}$. First stage heating (solar onily) is selected by the thermostat when roon temperature falis below $20.38^{\circ} \mathrm{C}\left(68.7^{\circ} \mathrm{F}\right)$ by activating the fan. Second stige heating (resistance) is activated in ajaition to that available from solar if room temperature falls below $19.38^{\circ} \mathrm{C}\left(66.0^{\circ} \mathrm{F}\right)$. 


\section{APPENDIX F \\ DESIGN REVIEW COMMENTS}
Appendix F-1. NASA Design Review Comments on InterTechnology Corpora- tion's Original System Design (December 20, 1976)

Appendix F-2. Reply to NASA Review Comments Letter from Norman C. Pardue, Jr. Consulting Civil Engineer

Appendix F-3. Reply to NASA Review Comments by InterTechnology Corporation 
APPENDIX F-I

NASA DESIGN REVIEW COMMENTS

ON INTERTECHNOLOGY CORPORATION'S

ORIGINAL SYSTEM DESIGN

(DECEMBER 20, 1976) 


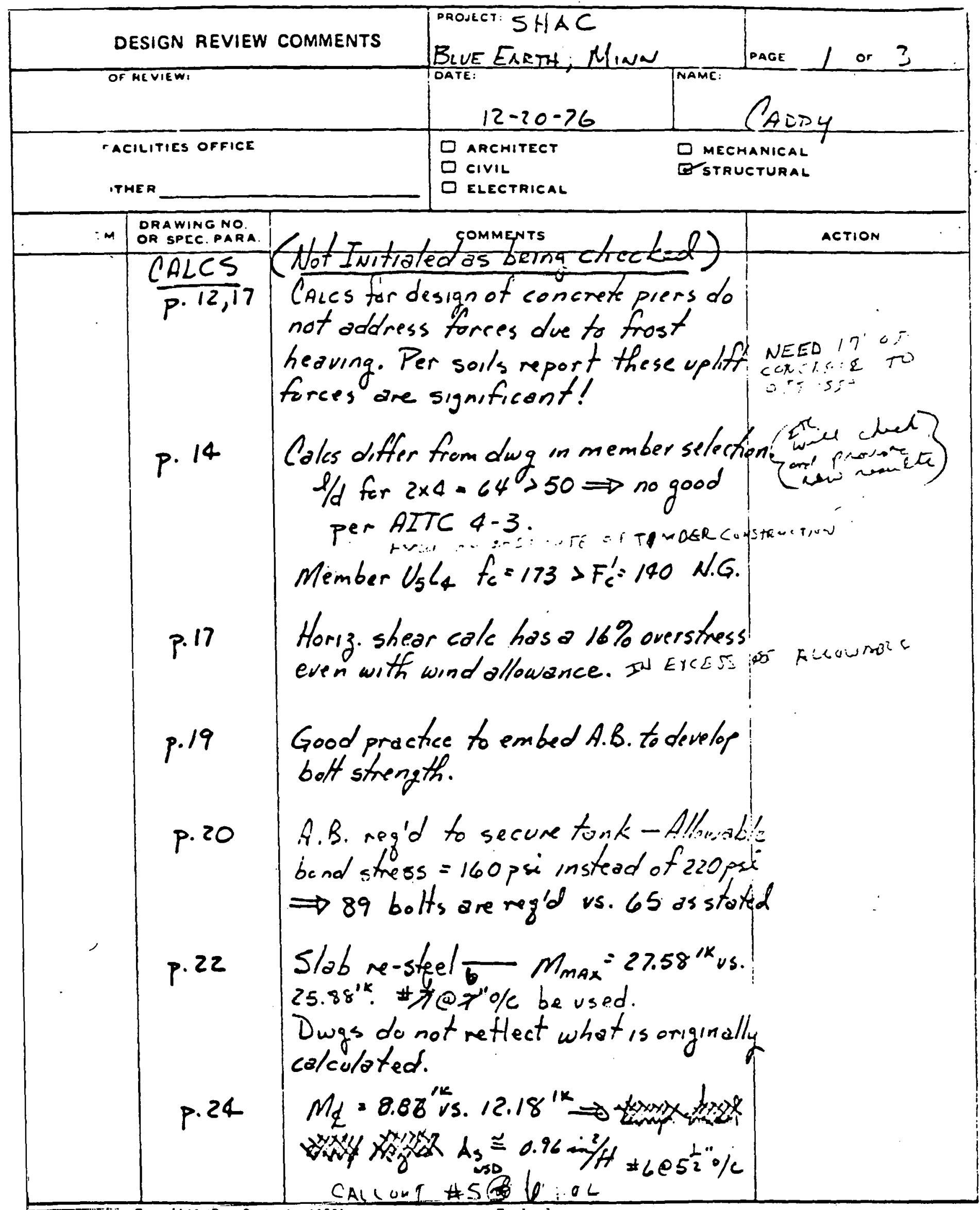




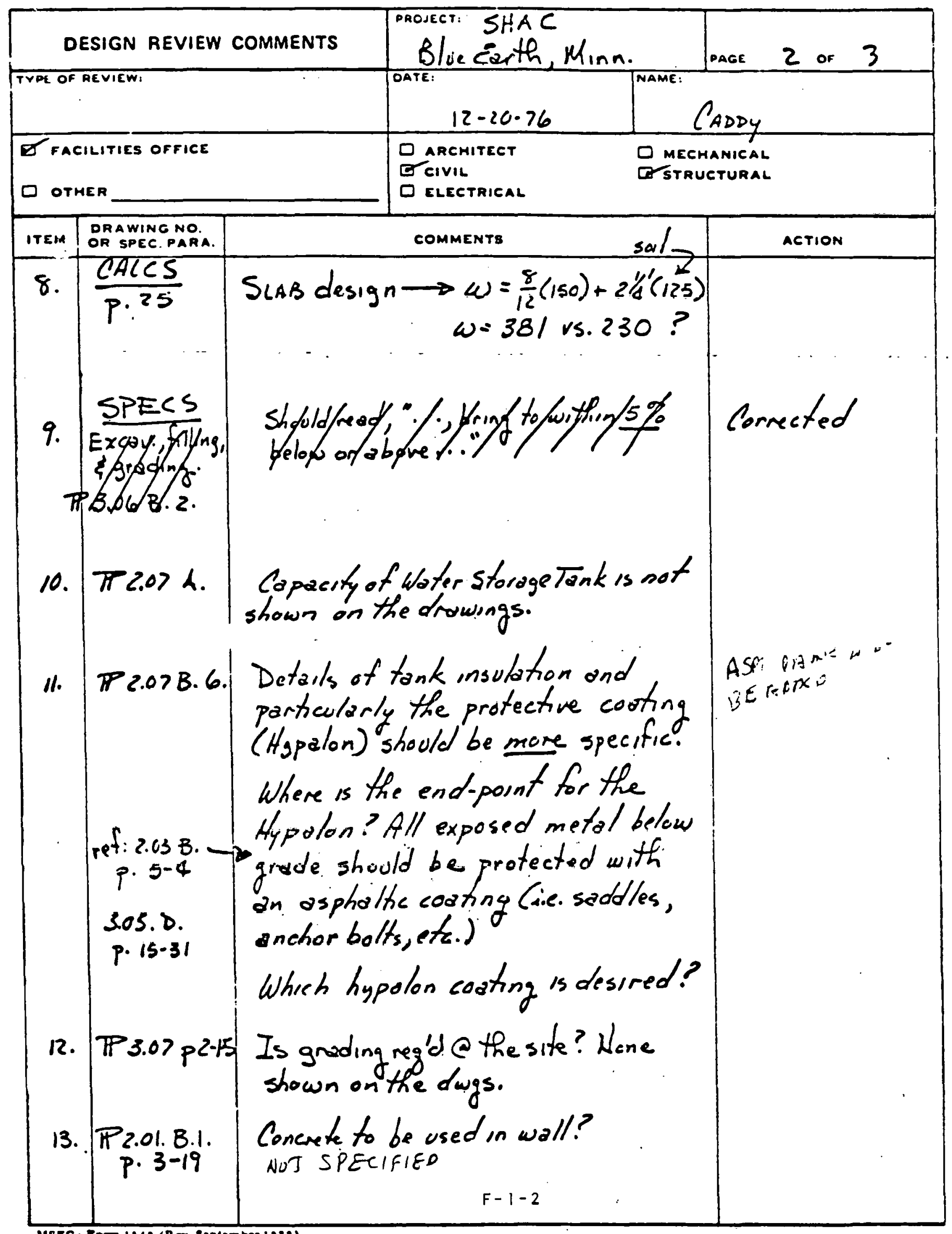




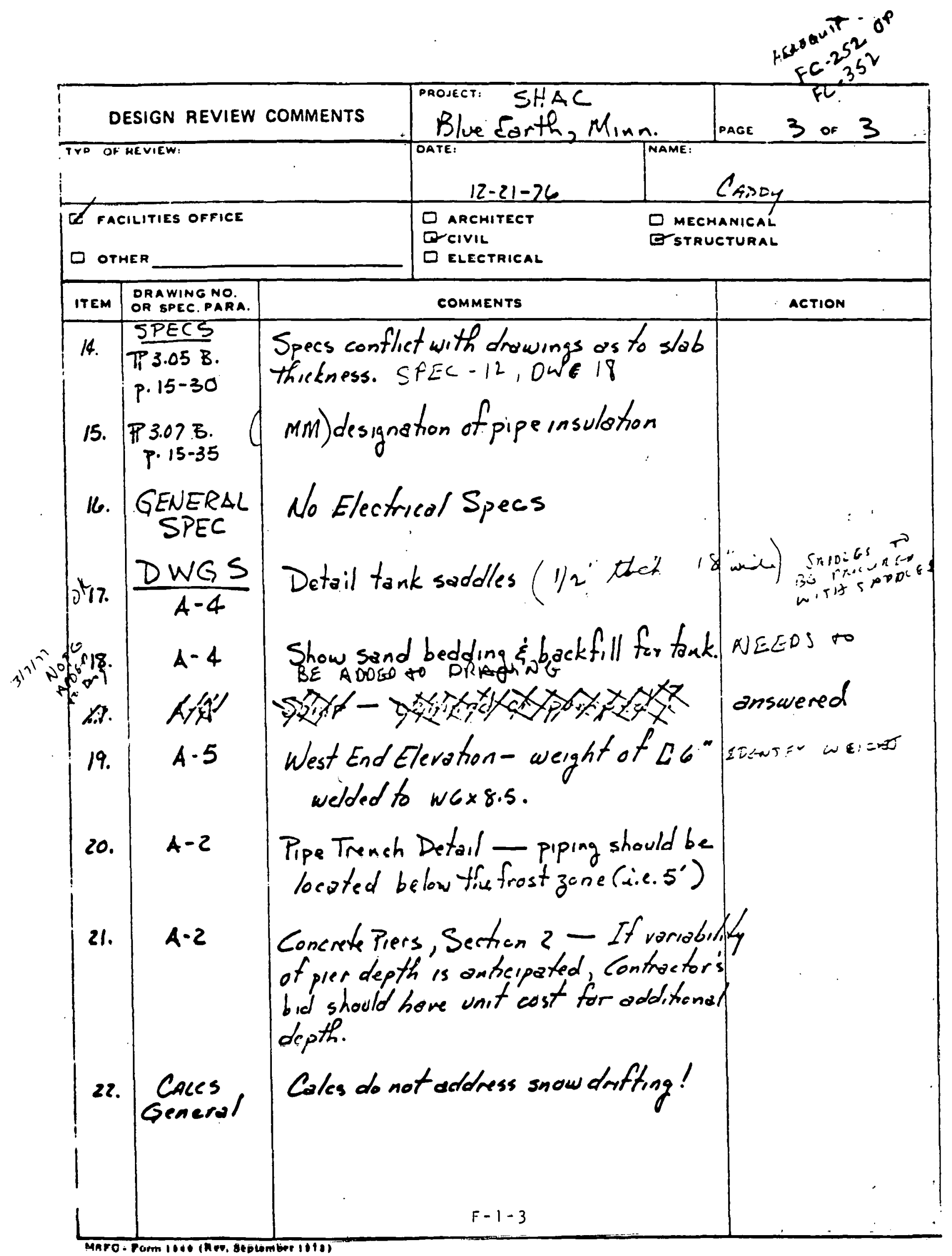




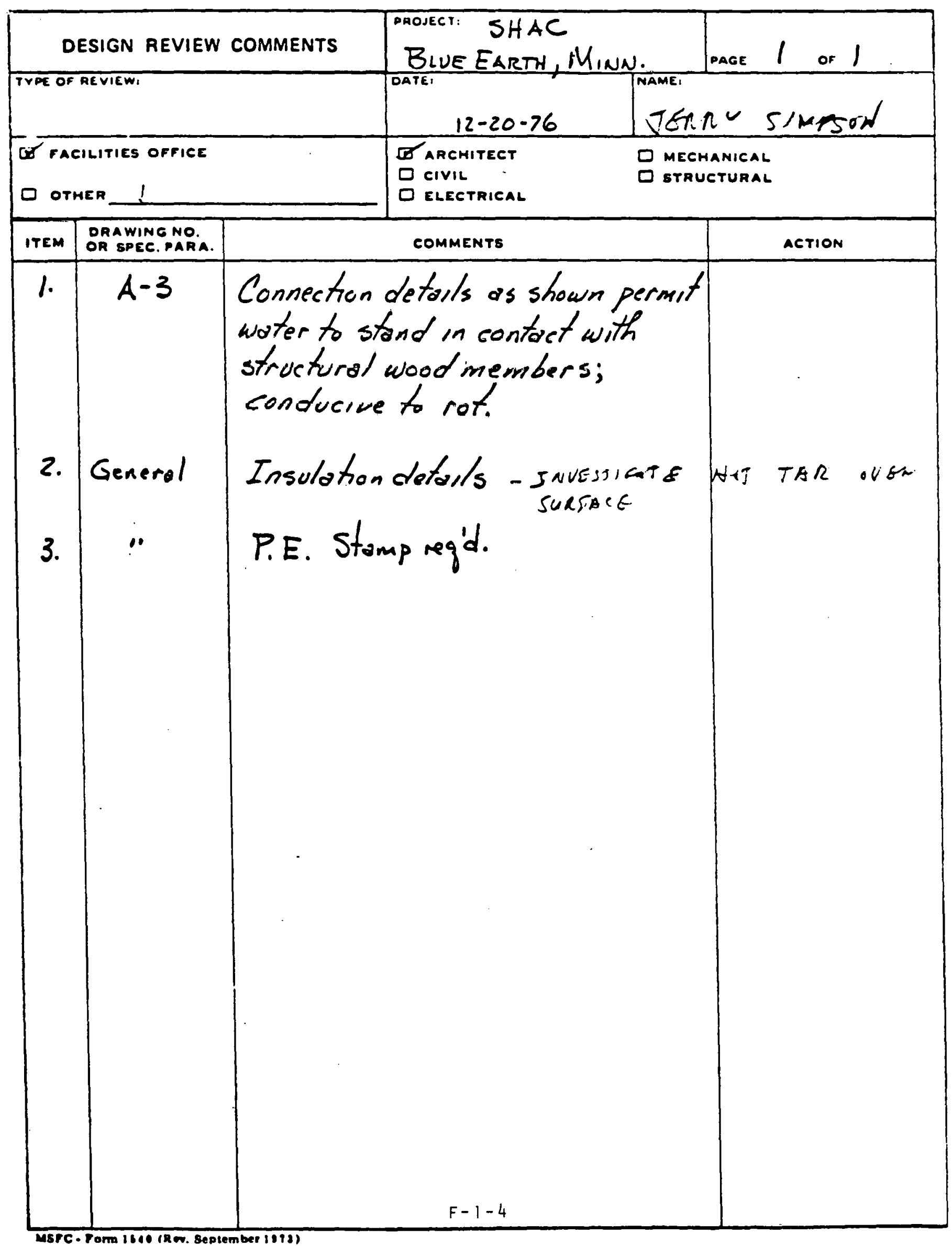




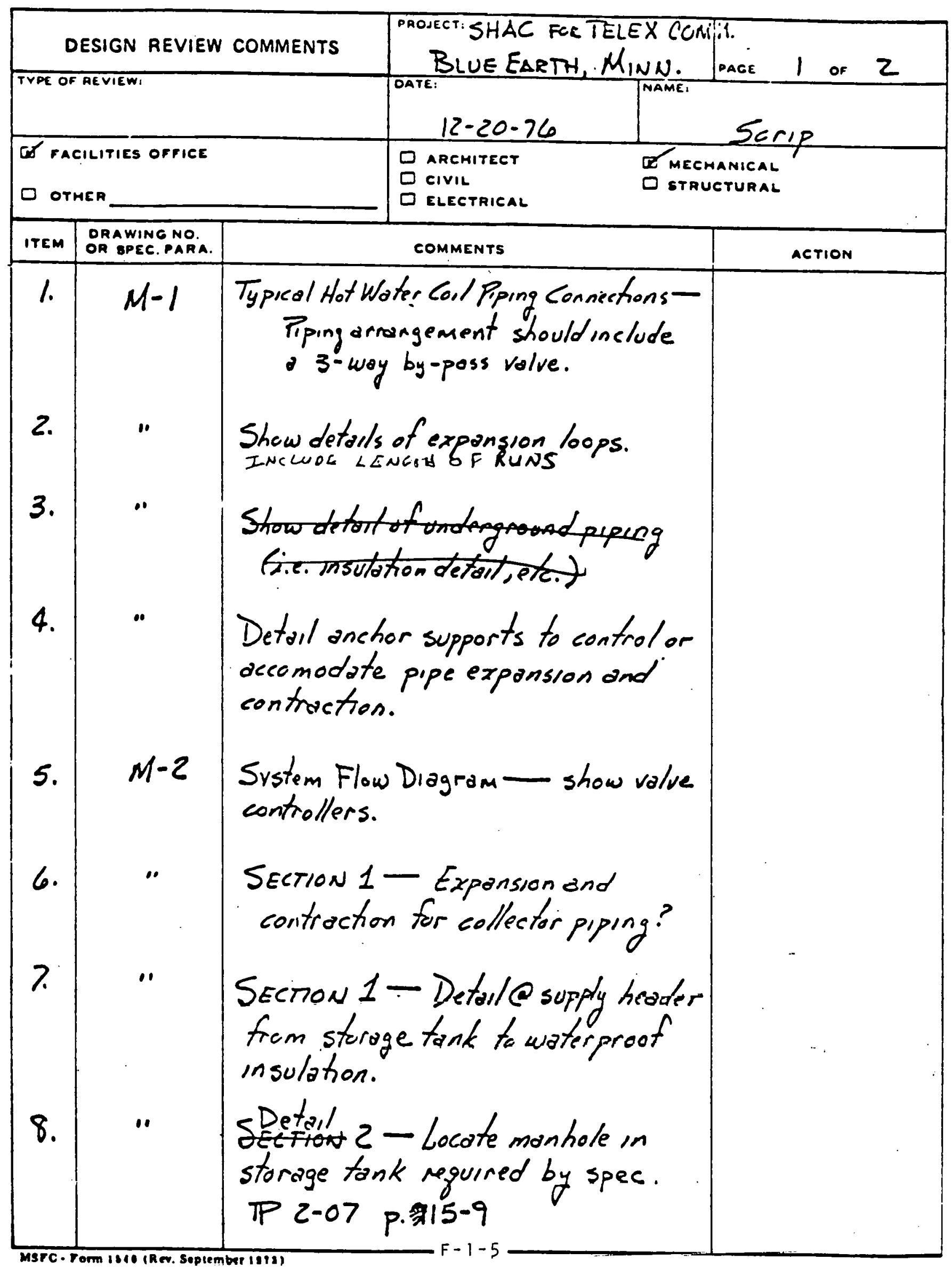




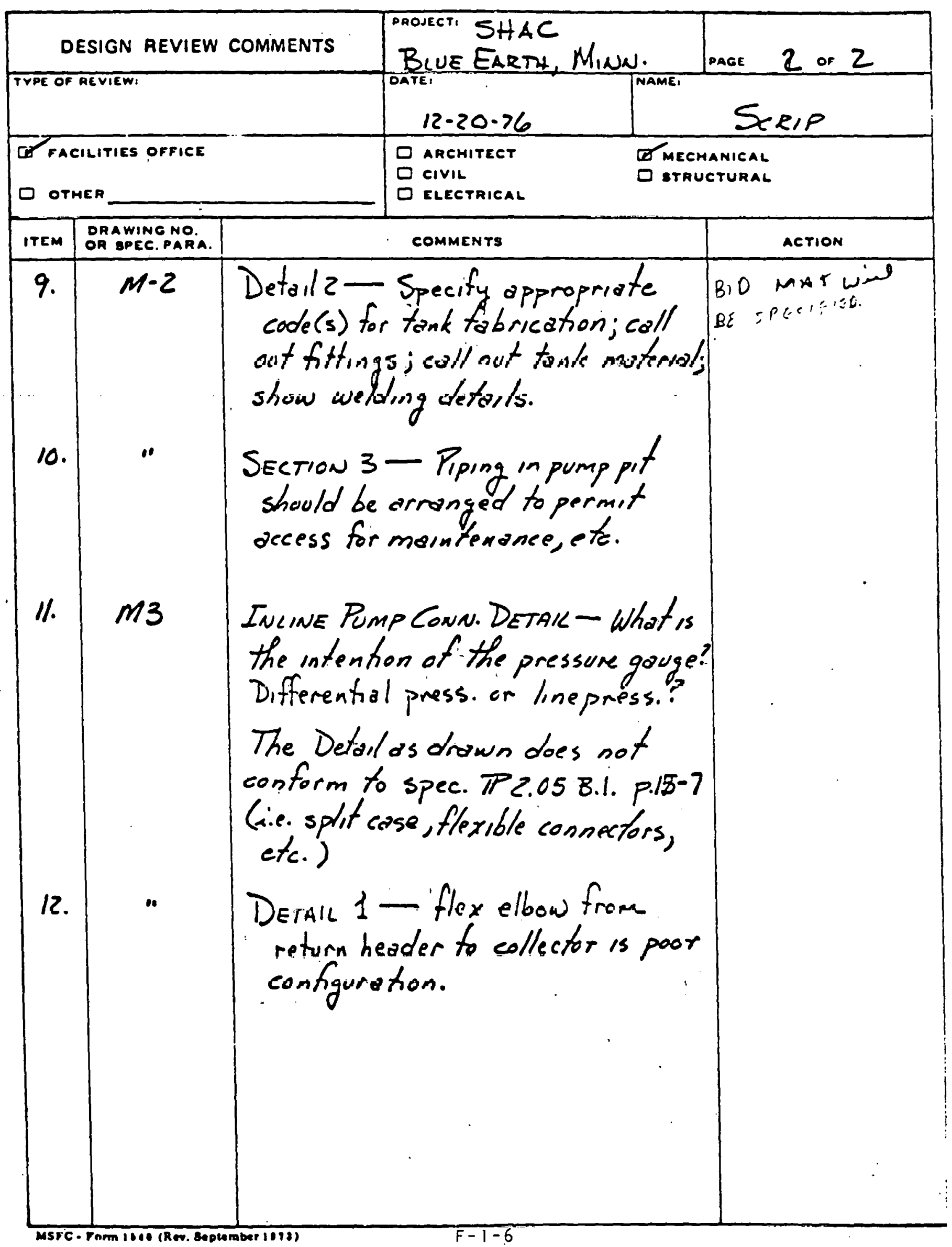




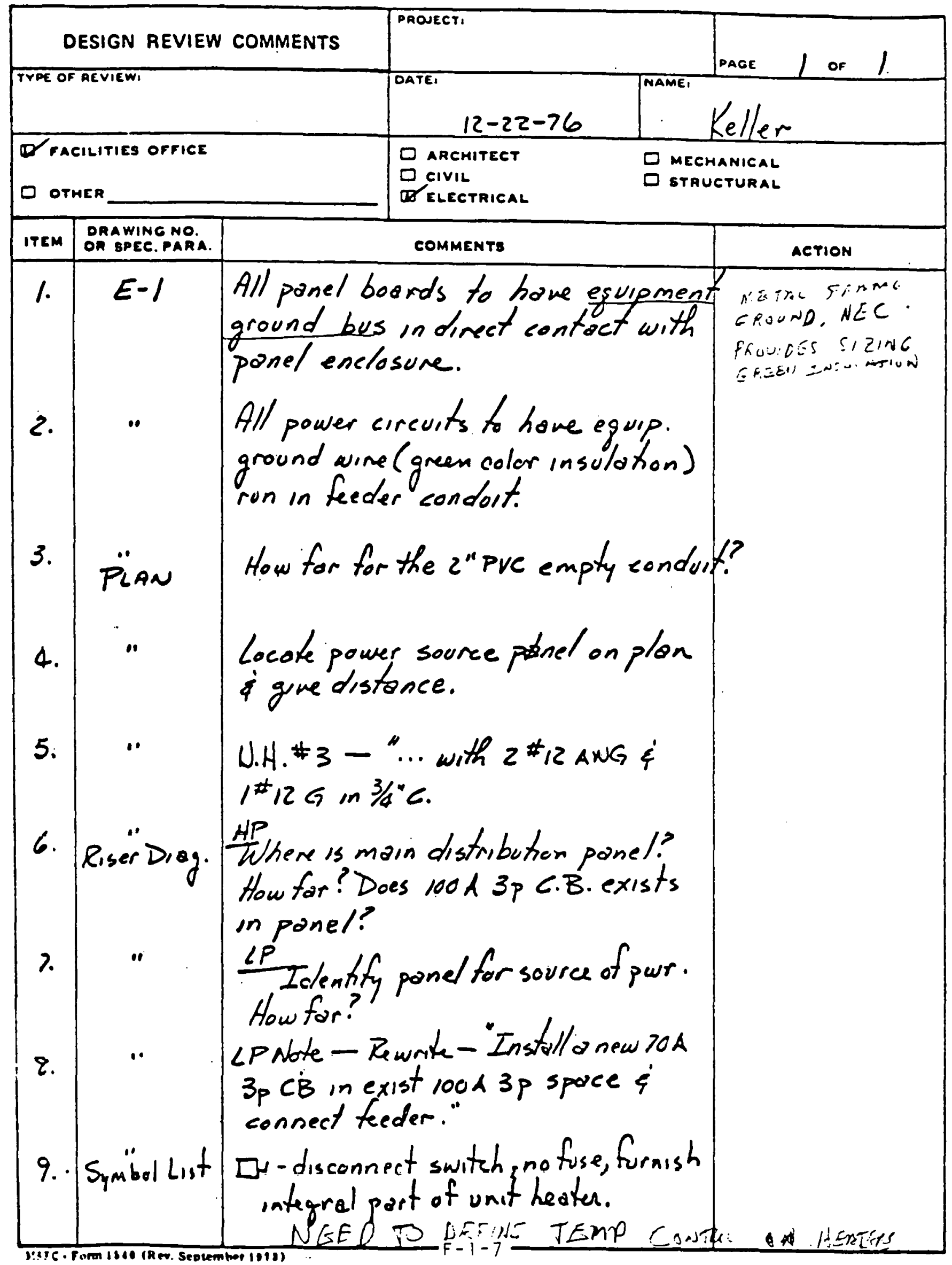




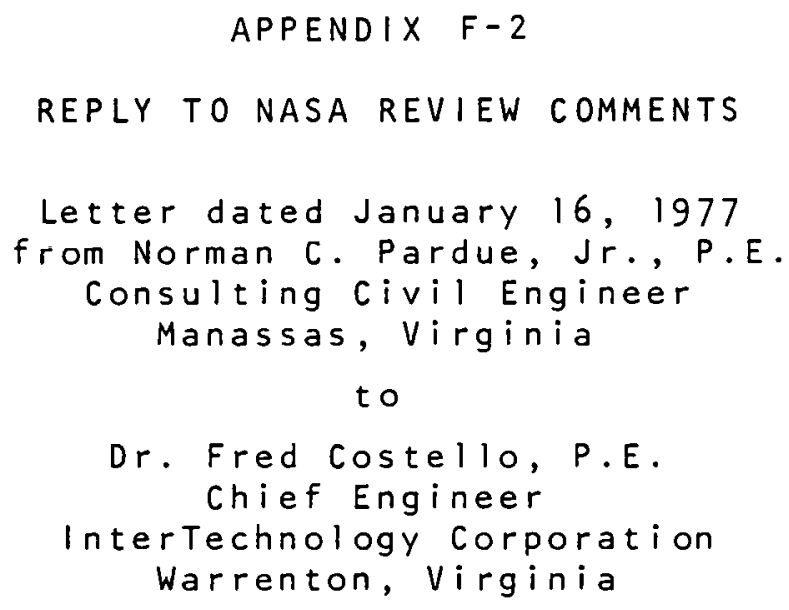


noRman C. PAROUE, JR., P.E.

COMEULTINO CML CNOINECA

cons ocn. cowosiaceta ume

marnsene. naginu seiro

(70)1 724.4284

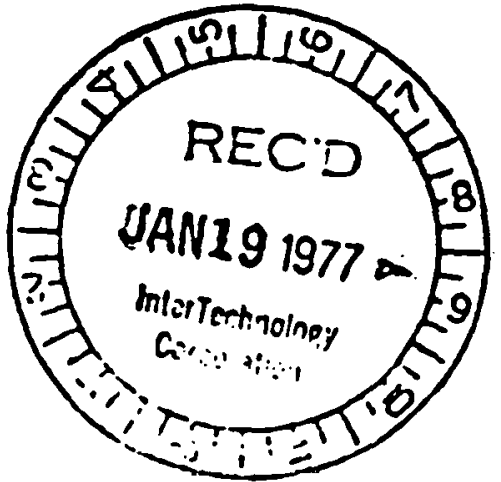

Res Telex Compunications, Inc.

Blue Earth, Minnesota

Solar Heating System Project

ERDA contract no. E(49-18)2376

Dr. Fred Costello, P.E.

Chief Engineer

InterTechnology Corporation

Harrenton, V1roln1a 22186

Dear Fred:

As ITC's structural consultant, I have reviewed the structural portion of the NASA design review comments. I find most of the comments to be extremely fallacious and misleading. In many instances the review comente show a lack of sound, practical engineering judgement and an inability to read elther the calculations or design drawlngs. There are gross errors in fact regarding what is purported to be in the calculations and design drawings. I an much dismayed and incensed at the quality of the review and the professional ethics of the NASA men involved for not glving me or ITC the courtesy of a phone call for clarifications on questions that they had prior to 1ssuling a formal review report to your client (Telex). And, I can well appreclate your concern about misplacing your trust in me when fallacious comments, such as these, are made about ny calculations and professional judgement. The damage of such mendacity has been done and no rebuttle, however effective, is as potent as the intial charges. Fortunately, our relationship is such that I hope these review comments will not adversely affect the goodw1ll I have enjoyed up til now.

NASA certainly has performed no detalled review analysis and design of the structural portion of the project. It appears that the reviewers merely flagged areas in the design and calculations where in my judgement negligible overstressing was permissible and noted as so. (I will explain later in this letter the rationale behind such judgements.) In other instances, the revieners: citeeas faults design situations that do not exist. For instance, iten 3 of the revie: comments cites page 17 of the calculatiors for overstress in horlzontal shear of a notched beam. Casual review of the design drawings by the design revlewers would have revealed to them that no such situation exists. This calculation was a determination of the stresses that existed at an earlier time in the course of the calculations when notching of the diagonal $2 \times 6$ struts was consldered to acconmodate jo1st hangers. Th1s Idea was later dismissed, partially because of the calculation of the overstress. Calculations by their very nature are not stat1c, but 
reflect the enflneer's continuing evaluation and judgement. Another instance of such fross misrepresentation is found in review comnent 1 tem 4 where the design reviewers cite page 19 of the calculations for using $3 / 4^{\prime \prime} \phi$ anchor bolts in the concrete plers. These being, they clalm, oversized bolts. Casual revlew of the calculatlons and design plans wil reveal no mention of $3 / 4^{\mathrm{m}} \phi$ anchor bolts in the concrete plers. The calculations call for $1 / 2^{\prime \prime} \phi$ anchor bolts with $6 "$ embedment as do the desion plans. The most blatant example of poor practical engineering judgenent is 1 liustrated in the desion review comnent 1tem 1 where the desion reviowers cite a 17 foot deep concrete pler as possibly beling required. A good size high rise buliding. I suspect, could be supported on such a foundation. I sincerely question the qualifications of the design reviewers. A registered, professional clvil or structural englneex with experlence in design would not even suggest a 17 foot deep pler, nor would such a qualified individual misinterpret or misrepresent the sicuations cited above. Further, it dismayed me that the reviewers did not question more pertinent design criteriat such as the active, and passive soll pressure or the soll density. These criteria are not found in the solls report, but were requested of Mr. IDonovan Stormoe over the phone by me and later documented in a letter (attached). It also dismayed me that the reviewers did not catch the errors in the calculations that I was arare of but had not corrected due to their insignificance. There are many other such fallaclous statements which I w1Il cover later in this letter.

It is my feeling that ITC must rebut 1tem by item these perniclous comments as not only is my pcofessional reputation at stake, but ITC's as well. However, before I rebut each 1tem I would first like to elaborate on the nature of structural calculations in the field of civil engineering and what is required of engineering judgement.

Anoung the major responsiblities of the consulting structirral engineer is to provide his client with a structure that serves the cllent's needs, is economical, and is not hazardous to health or iffe. In performing those funcions he draws on many jears of education and experience to solve design problems. Particularly important for developing a snlution for structural designs are calculations and deslon plans (or akotches). It would be extremely misleading to assume that the structural englneer analysises or designs every item of a design through mantpulation of numbers, formulas and code requirements. Many of the things considered by the practicing enflneer never get down on the paper. Other considerations are so obvious to the practicing enginter that he may merely cite his reasoning as "by inspection:" Iong beans, for instance, will probably be more critical in bending rather than in shear. An experienced structural engtneer may likely not show a calculation for the shear stress, or only once for one beam and not for other simillar beans. Likewise, by experlence a practicing engineer will not show cumputations for a solution to a situation in which by experience the engineer knows beforehand the proper solution. I an referring here to 1 tem 14 of the mechantical section of the design review.

The test of the structural design is not the amount. of calculations performed or their rifid computational accuracy. AII structural designs by their very nature are models, and as such are subject to varlations in modeling as performed by each structural enfineer. The true test 16 the reasonableness of the engineer's approach, and the wt1mate solutions does it perform 1ts function? Throughout all of this the structural englneer must

$$
F-2-2
$$


exercise his professional judgement. Codes, for all the1r value, are merely one measure of a structure's adequacy and in many instances the codes are Inadequato or grossly sever (see the 1976 Englneering Neus-Record artical on Henry Degenkolb, Consulting Structural Engineer). S1tuatiors and codes Invarlably call upon the englneer to exercise hls rational judgenent based on his experience. Examples of some areas that require such judgements are determination of what consitutes lateral support for a bean or what consitutes fixity for a colunn. Further, in the course of a design the structural englneer may come across a nember that is slightly overstressed. It 18 at that type of 81tuation where the designer must reflect on the design philosophy, load assumptions, safety factors, modeling, computational accuracy, as well as, the real world situation in determiniss whether to accept the menber or reject 1t. This type of judgement can only be done by an englneer who has thoroughig absorbed the design philosophy and computations. Typically, a structural engineer may comment that ho will be more conservative in designing colums than in designing beams, thus reflecting his appreciation of the relative importance of these members. The foregoing, by way of lilustration, consitutes in a $8 \mathrm{mall}$ way what is meant by "englneering judgement."

Englneering judgement intially requires adopting a design philosophy. It would be clarifyling here to state that I was consulted to design an economical structure that would have at least a twenty year 11fe. This was ITC's major concern regarding the structure (1n addition to 1 ts practical functioning). This design philosophy is totally justified, as solar en ergy systems are costing much nore than the commoniy advertised $\$ 20$ per square foot of collector area. Experience Indicates that costs in the neighborhood of between $\$ 40$ and $\$ 80$ per square foot are more $11 k e l y$. At these costs, It has been explained to me solar energy may not prove competitive with other conventional energy sources. With this in mind, I opted for wood as the structural material. Treated wood easily has a twenty year 11fe; It is eas1ly constructed and malntained; and. 1s one of the least expensive structural materlals. Likerise, when Mr. Stormoe, the soils engineer, reported requiring a bell footing at the end of the concrete pier. I questioned him on his design philosophy. I explained to him that the cost of such a foundation would be excessive and unjustified. I told him that we could tolerate seasonal movements of the structure up and down provided we did not get excessive differential movement. I again questloned him about a foundation curb. He discouraged the curb ldea citing that water would freeze under such a footing and subject the structure to differential heaving: Understanding our requirements of an inexpensive, but functional foundation that, would not be exposed to differential heaving, he recommended a drilled and castin-place concrete pier with a tip elevation below the frost line.

(During the course of our conversation, Mr. Stormoe mentioned that he had been recently involved in the foundation requirements for afrport runway lamps which require no movement and that the bell footing was a carry over from his design philosophy on the previous project. He felt that if movement could be tolerated, then certainly a bell footing was an excessive requirement.) Attached is a copg of a letter from $\mathrm{hr}$. Stormoe documenting this, as well as, the active and passive soll pressures and 8011 density. 


\section{REBUTTAL OF DESIGN REVIEN COMMINTS}

ITEM:

1. I have checked these calculations. There is no code requirement that I know of that require calculations to be initialed as being checked. To be sure, many consulting offlces may require this of their employees. In some offices this may be very rigorous i in others very lax. In some offices merely the approval of the chief englneer 18 required on the final design. In any event, these structures are not of such compexity (nor a hazard to I1fe) to warrant a Ilgorous independent check by another structural engineer. A consultant, such as myself, rigorously reviews his own designs prlor to the formal submission for construction bids or building permits. It is understood by ITC that I should be consulted agaln for complete document revien prlor to 1ssue for bias or buliding permits.

The concrete plers do not address forces due to frost heave as we can tolerate seasonal movement of the structure, so long as it 18 not differential movenent. The s011s enfloeer was consulted concerning this. See his attached letter and the body of this letter for further ampliflcation.

2. I do not see any discrepancy between the members selected in the calculations and as shown on the drawlings. The reviewers nay have outdated prints.

In regard to the $L / d$ ratio comment citing the A.I.T.C. requirement that $I / d$ for simple columns be equal or less than 50 (I/d $\leq 50$ ). let it be understood that this is an area in which englneering judgement must prevall. When computing the stresses in, the members, I did not feel it warranted to comply with the $L / d$ requirement since the allowable stresses conputed for the $2 \times 4: \mathrm{s}$ was based on

$$
F_{\mathrm{C}}=\frac{0.3 \mathrm{E}}{(\mathrm{I} / \mathrm{d})^{2}}
$$

which reduces allowable stress inversely as the (I/d) ${ }^{2}$ rat10 increases. And, in addition. I felt that my design loads in the critical reversal conditionwere excessive. The lange compressive force in Ug $\mathrm{U}_{4}$ ( $175 \mathrm{lbs}$. ) is the result of $a$ wind load from the back of the collectors. I computed this load at 1.75 t1mes the wind load from the front of the collectors to account for wind suction. If one reviews the Uniform Bullding Code (UBC, $1976 \mathrm{ed}$.$) section 2311,c. one will find that it$ states "Roofs of unenclosed bulldings, roof overhangs . . . or similiar structures unenclosed on one or more sides shall be designed to withstand upward pressures equal to one and one-fourth times those values set forth in Table No. 23-F." A copy is attached. This is merely one of the considerations I made while considering the use of $2 \times 4^{\prime} \mathrm{s}$. Additional considerations that I took into account were the function of the structure and the consequences of its fallure. As for the function, there is no hazard to ilfe should the structure fall; the loading condition would be extremely unlikely and temporary 1n.nature; and, in any event, the truss plates provide some fixity for the member Ugly. Also, the UBC wlad table alght allow a 15 psf design load in this area of Minnesota. See attached charts. We have checked with the local bullding department and they require a 20 psf 
deslon wind load, but they might concede that lowering the wind load requirement for this structure would be in order. Nevertheless, let us revier the design considering 20psf wind load. Let us first reduce reversal forces in propo rt lon to the UBC requirements. Lat us alsa in view of the incorrect loading of the truss, correct the applied loads. I had been aware of thls error earlier, but have not changed the computations to reflect it because the error 18 inconsequent1al to the final design. I was dismayed that with all that was considered by the revlewers that they had not c1ted this.

\section{Hind from the Ilghts seo calculation page 13}

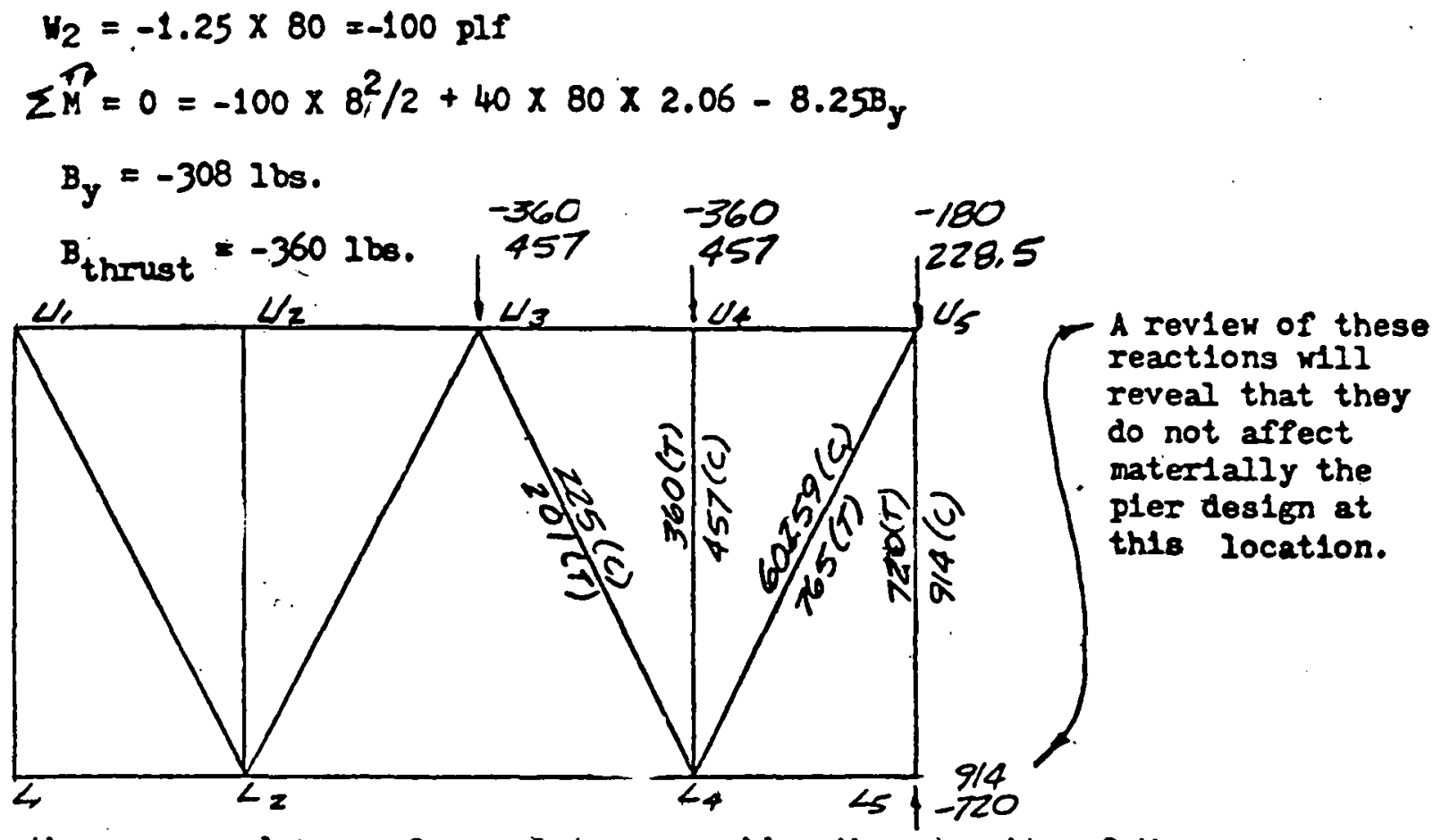

With the corrected truss forces let us consider the capacity of the members. As I mentioned earl1er the $I / d \leq 50$ requirement I felt under certatn clrcumstances warranted being neglected when in the judgement of the engineer the structure wllI perform adequately for its function. Remembr that this structure is not a bullding. Armed with this design review's questioning my judgement concerning the sizing of the inembers for the truss, I decided to call outside independent agencles for their requirements. I particularly wanted information on simple wood column fixity and the basis of setting an arbitrary L/d ratio for wood columns reqardless of loading conditions and fixity. It seemed unreasonable to me that $2 \times 4$ columns 1ightly loaded or temporarily heavily loaded should be required to conform to a maximum length of 6.25 feet. In fact if one reads the A.I.T.C. section $4-3$ cited by the design reviewers, it states in the second and third paragraphs justification for the use of engineering judgements

"The procedures presented have been found to be the methods most sufted to the particular member or systen in question: however, other methods may be used 19 substantlated by tests or sound englneering principles.

"The examples are 1Ilustrative only. In actual deslon, all the . conditions which wight be expected to have a bearlng on the ablilty 
of the member or structure to support all ant1c1pated loads safely should be considered."

To settle the question I called Mr. Bob Hewit, Director of Englincering of the National Forest Product Assoclation (IFPA), Washington, D. C. which publishes the National Desim Specification for Stress-Grade Lumber and Its Fastenings. I explalned to hin the Information I was looking for and he recommended the following USDA reports "Test of Large TImber Columns and Presentation of Forest Product Laboratory Column Formula" by Newlin and Cahagan (technical bulletin \#167, 1930). Th1s may be obtalned at P.O. Box 5130, Madison, Wisconsin or possibly from the government printing office. I asked whether this would apply to small columns and he Indicated that 1t would. A discission of the I/d rat1o linitation would be found there. I then explained in more detall the specifios of my problem of trylus lo deleimlie an eti"ective $L$ for a $2 x 4$ compression nember in a wood truss clting the temporary nature of the loads and the fixity at the connections as ample justiflcation for using a $2 \times 4$ of an I/d ratio greater than 50. He then pointed out the NIPA is in the process of revising their code requirements concerning the I/d ratio statement to include a provision for the engineer's judgement in determining fixity at the connections. This has been a source of controversy anoung englneers. Some maintain that no allowance can be made. Others maintaln that an allowance for fixtty can be made. Nr. Hewlt indicated that the origlnial intention was for the engineer to apply his judgement and that this new code is beling revised to clear up the controversy. I asked if the A.I.T.C. will concur in their new code, and he informed me that one of the directors of the NFPA sits on the board of the A.I.T.C. and they are revising their code llketlse. Hewlt also offered that the Canadian Code already reflects this pending change and that there have been many instances of $2 \times 4^{\circ} \mathrm{s}$ being used in situations as columns with effective lengths over 6.25 feet; however, he Inaged that the applied loads were low. He then recommended that I talk with Bob Spangler, Managing Director of the Truss Plate Institute, Washington, D.C. regarding column flxity provided by truss plate connectors. Mr. Spangler told me that the Truss Plate Institute's design specification allow an effective $L$ factor of .8 for compression members in a truss, and that certainly there are $2 \times 4^{\prime} \mathrm{s}$ in compression used in trusses that are longer than 6.25 feet. He volunteered that actual studies by an independent testing agency found that. the effective I factor to be more in the range of.$?$. Bascd on these discussions and my mmfessional judgement, I do not feel that there should be any concern for the adequacy of the truss as designed. See attached spectfications.

Nok in this Iight, let us examine the truss members again. Certalnly, there are members whose $I / d$ ratio exceod 50 , and there aro possibly members whose effective L/d rat10 exceed 50 , but are the stresses in the members significant. 
$U_{5} L_{5}$

$$
\begin{aligned}
& F_{c}=\frac{P}{Z}=\frac{914}{.5 .25}=174 \mathrm{ps} 1 \\
& F_{c}=\frac{0.32}{(\mathrm{~L} \cdot / \mathrm{d})^{2}}=\frac{.3 \times 1.5 \times 10^{6}}{(.8 \times 92 / 1.5)^{2}}=186.9 \mathrm{po1}>I_{c}-0 k \\
& K / \mathrm{d}=.8 \times 92 / 1.5=49<50-0 k
\end{aligned}
$$

Notes thls does not include a $1 / 3$ increase in otrese duo wind loading.

$\therefore$ Use 2X4 DFL - studs srade

$\mathbf{U}^{\mathbf{I}_{4}}$

$I_{c}=\frac{P}{T}=\frac{602.59}{5.25}=114.8 \mathrm{ps} 1$

$F_{c}=\frac{0.3 E}{(\mathrm{~L} / \mathrm{d})^{2}}=\frac{.3 \times 1.8 \times 10^{6}}{(.8 \times 94 / 1.5)^{2}}=215 \mathrm{pst}>\mathrm{f}_{\mathrm{c}}-0 \mathrm{k}$

$\mathrm{KL} / \mathrm{d}=.8 \times \cdot 94 / 1.5=50.13 \cong 50$ - say ok

Noter this does not include a $1 / 3$ increase in stress due ust loading.

$\therefore$ Use $2 \times 4$ DFL - No. 1 grade

Other members in the truss can IIkewise be justifled, especlally in vieu of their considerably lower loadings.

Please note that in the origlnal calculations U $\mathrm{JL}_{4}$ was not otressed to 173 psi as was purported in the design revlew comments. Agatn they have misread and misinterpreted the calculations.

3. As noted in the body of this letter, a situation with iorizontal shear in a notched beam does not exist. The review comment is fallacious in its import.

4. This comment is erroneous in stating that it is good practice to ombed anchor bolts to develop bolt strength. See response to item 5 below. It is also erroneous in stating that I called for $3 / 4 " \phi$ anchor bolts for the plers, nor is this indicated anywhere in the drawings. I call for $1 / 2^{n} \phi$ anchor bolts with 6 inches of embed ment to resist tension.

5. Typically, anchor bolts are not deslgned to develop concrete bond strese nor bolt stress. Th1s is the type approach used to develop deformed reinforcing bars (rebars). An anchor bolt is not a rebar. Typically. anchor bolts are designed with concrete shear strength as the rode of fallure to be avolded. When designing anchor bolts the structural englneer has several alternatives. I w1ll only mention two here. Theoretical design of anchor bolts is quite complex and generally not warranted except in sophistlcated structures requirling 11kewlse design calculations. Most structural onglnoers will refer to a bulliding code like the UBC. See Table No. 26-G, "Allowable Shear and Tension on Bolts" (attached).

In Item no. 4 above I call for a $1 / 2^{\prime \prime} \%$ anchor bolt with 6" embedent The UBC allows a 950 Ibs. tension load in a $1 / 2^{\circ} \mathrm{B}$ A.B. Wth $4^{\prime \prime}$ embednent $F-2-7$ 
Wth inspection for proper placement, that value ray be increased $100 \%$ wh1ch 1819001 bs., and considering that such loading is due to wind, we can allow a $1 / 3$ increase which is 2527 Ibs $>2100$ Ibs - ok.

Now let us consider the design reviex comment that 89 anchor bolts are required versus ITC's 65 to secure the tank. Consider one thing first, it is highly unlikely that this tank will be burled and not contain Iiquid; thus no bouyancy effect. If the condition should occur 1t will only be of short duration. Referring to UBC Table No. 26-C we find that $3 / 4^{\prime \prime} \phi$ anchor bolts with $5^{\prime \prime}$ embedment are good for load of 2250 Ibs. each. If the englneer inspects the bolts for proper placement, the allowable load may be Increased $100 \%$ to $4500 \mathrm{Ibs}$. each. If one considers the temporary nature of the loading a $1 / 3$ increase should be allowed. Then due to the temporary nature of the loading, the capacity of the bolt would be in the range of 5985 Ibs. each.

$$
\text { No. A.B. req'd. }=\frac{\text { bouyancy foroo }}{\text { bolt capacity }}=\frac{311^{k}}{5.985} \mathrm{k} / 601 t=52 \text { wolks. }
$$

In actual fact ITC's deslgn provides for 70 anchor bolt.s whth 7 ' embedment (2" longer than the UBC minimum). This is perfectly adequate.

The other method a structural englneer might use to design anchor bolts would be similiar to the design method found in the Prestressed Concrete Inst1tute Design Handbook for Precast and Prestressed Concrete, figure 6.1.12 (attached) where formulas and theory are developed for tension capacity of weld headed studs in concreto. As I stated earller anchor bolts are not rebar and actually have, at the very least, a head which contributes to the developwent of a shear cone in the concrete Blmiliar to a weld headed stud. Illustrations

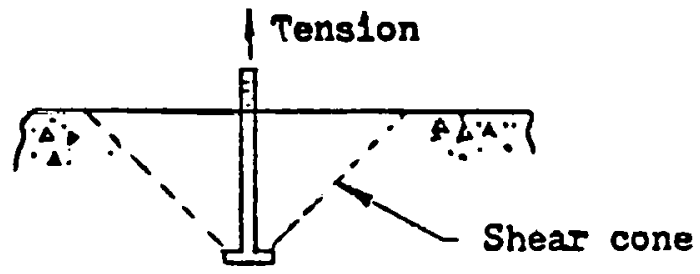

6. The slab rebar as designed are adequate. The design reviewers must have an old print, because I recall a drafting error in which the draftsmen mistakenly indicated the temperature rebas as the main rebars.

The rebars as shown on page 22 of the calculations are correct and the

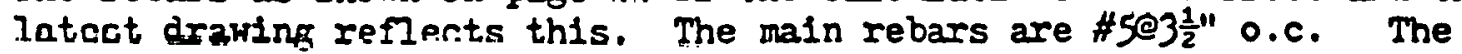
difference in moments as computed by the design reviewers versus the moments I computed is insignificant. One engineer's model may be more or less accurate than another's. Who is to say which?

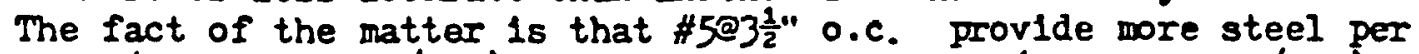
foot (1.05 sq. in./ft.) than either \# 07 " 0.c. (1.03 sq.in./ft.! or

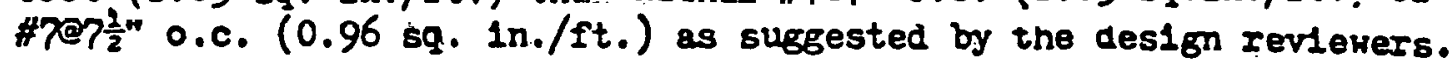

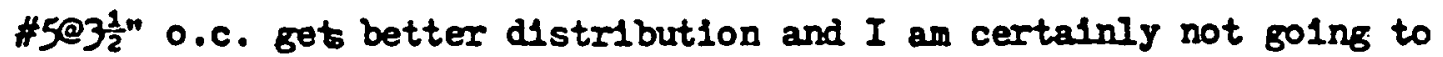
reduce the area of steel that I feel 18 required.

7. Again the difference in moments computed by the design reviewers and myself 18 insigniflcant. ITC's mont is reater and the calculations

$$
F-2-8
$$




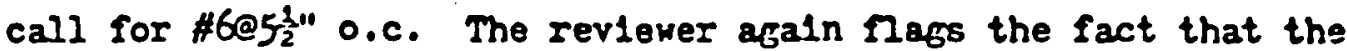
the drawing of the wall at the center line location indicates \#sest" $0 . c$. falling to notlce that the wall in the drawing 18 a $12^{\text {n }}$ wall while the wall in the calculations 18 a $9^{\prime \prime}$ wall. The reviewer may not have had the addendum to the calculations, but missing such an obvlous discrepancy certalnly casts doubt in my eyes as to his

redentials. A copy ot the structural calculation addendum is attached.

8. The design revlewers here lag the uniform load over the pump pit alab malntaining the Wri381 plf va.'ITC's 230 plf. Part of what has happened here is that my calculations reflect only a 1"-6" Found cover over the slab. After the computations, unknown to me, it was decided to Increase the cover to 2'-4". Nevertheless, it w1ll be shown that the slab design is adequate. (Notice that the reviewer did not 1nclude a live load on the slab. This is certalnly unrealistic.) It should also be noted that the slab was designed for simple bending ( $M=h_{L} 2 / 8$, urrestralned rotation at the supports) which 18 not totally realistic, but is conservative and in line uith englneering judgement. The slab has definite continustis at the walls

$$
\begin{aligned}
& W= .67 \times 150+40+2.25 \times 125=421.25 \mathrm{plf} \\
& \text { acrual span }=9^{\prime} \\
& M_{u}=1.4 \times \mathrm{wL}^{2} / 12 \text { (due to cont1nuity at the } \\
&=1.4 \times 421.25 \times 9^{2} / 12=3.98^{\mathrm{k}}<4.02^{\mathrm{k}}-\text { actual morts) }
\end{aligned}
$$

9. I do not have a copy of the specifications and therefore cannot comnent, except to say that it is understood by ITC that I have complete desifo review privileges and that any discrepancles will be corrected.

10. No comment required.

11. I have not been involved in the selection of the protective coating and expect others at. ITC to respond.

12. Site frading is not required as the site is level.

13. See 9 above.

14. See 9 above. 'An 18" slab is required.

15. See 9 above.

16. Not my area of responsibility.

17. Typically, tank saddles are not designed by consultants but by the vendor. It is the vendor's responsiblity to provide adequate and properly designed saddles.

18 Sand bedding and backfill are not required and represent an additional and unwarranted expense. He intend to the lay the tank on und 1sturbed

$$
F-2-9
$$


soll and backfill with the excavated so1l. Band $1811 \mathrm{kely}$ to compress, whereas the undisturbed soll 18 11kely not to. What is the rationale behind this?

19. $c 6 \times 8.2$

20. I question the validity of this requirement. My feeling is that provided the plpe 18 well insulated (I do not know if this 18 case) there 18 ilttie reason to require the plpe at

a lower elevation. At any rate lot us check with solls enginoer.

21. Varlability of the pler depth 18 not anticipated. See 80118 engineer's attached letter.

22. Snow drifting showd be a indnimal problem since the bottom of the solar collectors 154 feel above grade. Snnw w1ll not. stand on tho collectors and if 1 t should, the design loads based on wind loadings would be adequate. One does not apply simultaneously wind loads and snow loads under these design clrcumstances.

Architectural:

1. The wood is pressure treated per the specifications and it is highly unlikely that the wood will rot due to standing in water accumulated on the top of the plers.

2. I have not been consulted in this area.

3. A P.E. stamp is not required until the final design for submission to the bullding department. Preliminary designs are rarely (almost never) stamped by a reglotered englneer.

Mechanical:

I w1Il respond in this area only where I have had involvement.

14. This is an area where past experience and engineering judgement prevall. I have had lengthy experlence in the support of piping with Bechtel Corporation's Refinery and Chemical Division and based on this experience I determined that 24 foot spacing would be adequate. Attached is a copy of a design standard used by Bechtel in determining how offen to support piping. Note that they cite past experience in justifyling the deflection of the piping. If the reviewer is concerned about the bending stresses, shear stresses and deflecilion. It would be a simple matter for him to perform a moment distribution and find a criteria by which to judge the adequacy or inadequacy of the spacing. If my memory serves me well the plping sizis we are concerned here with are between $2^{\text {n }} \phi$ and 4" $\phi$. I will have to reviek the plping drawings to see if there is any reasonable concern.

I would like to restate that peior to this design being submitted formally for blds and the bullding permit that I should be consulted to revien that portion of the design plans and specifications that directly relate to my epecialty. In addition I should like to review the bld package 
for proper contractural arrangements to assure that the contractor complies with the design and speciflcatlons. During the course of preparing this rebuttie. I have notice additional alnor changes I would like to conslder, and I w1ll discuss these detalls with you at a later date.

In conclusion, I would like to assure you, your client and the NASA design reviewers that in my judgement there is nothing substantivaliy in error with the structural design for this project. Further, From what I have seen in these revieu comnents. I do not feel that NASA 18 qual1fled or in a position to judge the structural design for this project. Ve (ITC). I feel, have taken an in depth look at this project, and it 18 obvious to me that NASA has not.

Again, fallacious comnents as made by the design reviewers have no place in a formal professional review of this nature. Many of the problems the reviewers have had in revlewling the calculations and drawings could have been cleared up whth a simple courtesy phone call. I am not certain about a violation of professional ethics, but it is definitely suspect. I 1ntend to contact the American Soclety of Civil inglneers for their opinion. I certalnly feel that I and ITC are owed a formal epology for such perniclous coments to Telex prlor to our being consulted.

The reviewers and Teley should rest easy since this design is still subject to our review (and revision) which has been much wore substantive than NASA's review, and particularly in view of the fact that we are ultimately responsible for the design and not NASA.

If I can be of further assistance to you in this matter, please do not hesitate to call. Should the NASA revlewers $\mathrm{wlsh}$ to contact me, I may be reached at the followlng numbers: 202-872-8688 (days) or 703-307-9190 (erenings). Please note my new address at

75 s. Reymolds St, G120

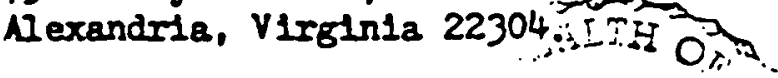

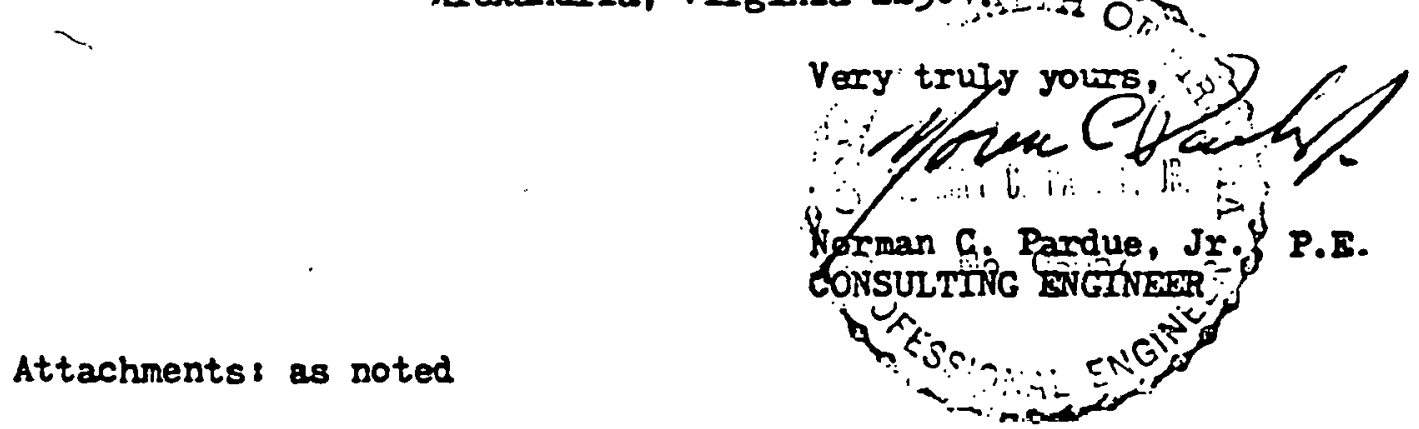


APPENDIX F-3

REPLY TO NASA REVIEW COMMENTS

BY INTERTECHNOLOGY CORPORATION 


\section{ARCHITECTURAL/STRUCTURAL COMMENTS}

We are limiting our remarks to NASA review comments on architecutural and structural to items 11,13 and 16 , of the structural review, and 1 and 2 of the architectural review. Our structural consultant has adequately answered the other items. NASA should refer to the attached letter for these remarks. We are, however, adding some additional comments to his answers on items 5,19 and 20.

ITEM

REMARK

5 Inspection will be requested per Section 03300, para. 3.01 A-2 of the specification, so the higher loading cited by the consultant apply.

11 See Sheet M-2, Section- 3 for the end points of the hyplon protective Coating. Corrosion proteztion for the exposed metals to be buried can be found in Section 15600, para. 2.07 B-4 of the specifications.

13 "Footings" in Section 03300, para. 2.01 B-1 should read "Pit Halls". This will be corrected in the $100 \%$ submission.

14 Specification should read 18 inch. This will be corrected in the $100 \%$ submission.

15 The dimension in millimeter $(0.40)$ will be added.

16 No Comment required.

19 Weight will be indicated on drawings at $100 \%$ submission.

20 Pipes from the storage tank to the building will be buried at $5^{\prime}$ below grade, the collector supply and return piping will remain at $3^{\prime}-0^{\prime \prime}$ below grade, and will be so indicated on the drawings for the $100 \%$ submittal. 


\section{ARCHITECTURAL}

1 In addition to the remark of our consultant, the amount of standing water on top of the piers at any given time will be insignificant.

2 NASA's comment includes the necessary reply.

3 Drawings shall be stamped on application for buliding permit. 


\section{MECHANICAL COMMENTS}

1 We disagree with the comments. We recommend the 2 way valve as designed for the following reasons:

a) Two-way valves allow only that quantity of water to flow through the underground supply and return matns which is actually required by the heating colls to satisfy the building heat load. The rest of the water is by-passed around the pump in the pit.

b) Reduced flow in several hundred feet of undergroud pipe reduces heat losses from pipes. The controls are designed such that our pump can be automatically shut down during prolonged periods of reduced heating loads.

c) Reduced tlow also results in reduced pipe friction losses which means savings in pumping horse power.

d) Two-way valves cost much less in material as well as installation costs.

2 Expansion loops have been sized according to the charts provided by the manufacturer of the specified pipe (Perma-Pipe) and the charts given in the Carrier Pipe Design Manual.

3 Comment withdrawn by NASA

4 We will provide an anchor support detail in our $100 \%$ submission.

5 In standard HVAC design practice only a description of control sequence is provided. A control diagram can be prepared if requested by the $c$ i ient.

6 High temperature flexible hose is not sensitive to ultra-violet sun rays. As NASA noted, the flexible hose accomodates expansion and contraction.

7 Comment withdrawn by NASA.

8 We will locate the manhole on our drawings. 
9 Tank materlal is called out in specifications section 2.07 page 9. He did not call out fittings because we were waiting for Instrumentation design from NASA so that all fittings can be called out together.

10 The piping in the pit has been designed to permit easy maintenance. The contractor is also required to submit shop drawings for all work. We plan to make necessary revisions at that time.

11 Specification Section 2.05 page 7 does not call for flexible connectors. It calls for flexible coupling between pump and motor. The words "Split Case" will be deleted from specifications.

12 All pipe penetrations will be added to the drawings in $100 \%$ submission.

13 According to the manufacturer, conduit at all the elbows is slightly oversized to accomodate pipe expansion. We will also call this out in our spectfications. See structural corments. 


\section{ELECTRICAL COMMENTS}

1 See Electrical specifications para. 1.07 grounding systems.

2 Same as item 1.

3 Same trench as for line shall be used.

4 We will comply in next submission.

5 Wire is oversized because of the long run from Panel board. Panel board will be shown in the next submission.

6 We will comply and show the panel in next submission.

7 We will comply and show the panel in next submission.

8 We do not understand the necessity of changing our wording.

9 We will comply. The heater is electric.

10 We will change to 200 watts.

11 Yes. 
APPENDIX G

TECHNICAL SPECIFICATIONS 
APPENDIX G

TECHNICAL SPECIFICATIONS

Collectors:

Storage:

Controls:

Underground $\mathrm{Pipe}$ :

Pumps - Collector:

- Load (2):

- Sump:

- Emergency Sump:

Collector Flow Balancing:

Floating Coils:

Unit Heaters:

Flow Switches:

Heating Control:

Water Treatment:

Valves $v-1, v-2$

Shut-off Valves on

collector:

Supply Lines

Space Heating Valves:
InterTechnology/Solar Corp. Mark III

Arrow Tank and Engineering Corp.

Johnson Controls

Rovanco Insul-8

Bell E Gossett $80-3 \times 3 \times 9 \frac{1}{2} \quad 7 \frac{1}{2} \mathrm{hp}$

Bell E Gossett $80-2 \frac{1}{2} \times 2 \frac{1}{2} \times 9 \frac{1}{2} \quad 5 \mathrm{hp}$

Aurora $531-4 \times 4 \times 7 \mathrm{~A} 2 \mathrm{hp}$

Peabody Barnes $151 \mathrm{CU}-13 \times 3$

Bell E Gossett Circuit Setters

McQuay 5 WH, 5 WS

McQuay UDH

MCDonnell FS4-3, FS4-3-20

Penn Controls M80J Proportional

Motor Activator

Penn Controls VgoAA 2-Way Single Seat Globe Valves

Culliqan Mark 512

Johnson Controls VB 3752 , VB3970 with VA3200 Electro-Hydraulic

Valve Activator

Milwaukee Bronze Gate Valves

Gate - Milwaukee

Balance - Rockwell Plug

Check - Milwaukee 
APPENDIX H

PERFORMANCE FACTORS AND SOLAR TERMS 
The performance factors identified in the site equations (Appendix C) by the use of acronyms or symbols are defined in this appendix.

section 1 describes general acronyms used in this report. Section 2 includes the acronym, the actual name of the performance factor, and a short definition.

Section 3 contains a glossary of solar terminology, in alphabetical order. These terms are included for quick reference by the reader.

Section 1. General Acronyms

Section 2. Performance Factor Definitions and.Acronyms

Section 3. Solar Terminology 
ATCE

ASHRAE

BTU

COP

DHW

ECSS

HWS

KWH

NSDN

SCS

SHS

SOLMET

TCE
Auxiliary Thermodynamic Conversion Equipment.

American Society of Heating, Refrigeration, and AirConditioning Engineering.

British Thermal Unit, a measure of heat energy. The quantity of heat required to raise the temperature of one pound of pure water one degree Fahrenheit. One BTU is equivalent to $2.928 \times 10^{-4} \mathrm{kwh}$ of electrical energy.

Coefficient of Performance. The ratio of total load to solar-source energy.

Domestic Hot Water.

Energy Collection and Storage System.

Domestic or Service Hot Water Subsystem.

Ki lowatt Hours, a measure of electrical energy. The product of kilowatts of electrical power applied to a load times the hours it is applied. One kwh is equivalent to 3,413 BTU of heat energy.

National Solar Data Network.

Space Cooling Subsystem.

Space Heating Subsystem.

Solar Radiation/Meteorology Data.

Thermodynamic Conversion Equipment. 


\section{SECTION 2}

\section{PERFORMANCE FACTOR DEFINITIONS AND ACRONYMS}

\begin{tabular}{ll} 
ACRONYM & \multicolumn{1}{c}{ NAME } \\
ASTECH & $\begin{array}{l}\text { Change in Energy Stored } \\
\text { in Cold Storage }\end{array}$ \\
ASTEFF & Cold Storage Efficiency \\
ASTEI & $\begin{array}{l}\text { Energy Delivered to } \\
\text { Cold Storage }\end{array}$ \\
ASTEO & Energy from Cold Storage \\
ASTLOSS & Cold Storage Loss \\
ATCECOP & $\begin{array}{l}\text { Auxiliary Cooling Subsystem } \\
\text { Coefficient of Performance }\end{array}$
\end{tabular}

ATCE1 Auxiliary Cooling Subsystem Thermal Energy Input

ATCEL Auxiliary Cooling Load

ATCEOPE Auxiliary Thermodynamic Conversion Equlpment Operating Energy

DEFINITION

Change in stored energy in cold storage during specific time period.

Ratio of the sum of energy supplied to cold storage and the change in cold storage energy to the energy removed from cold storage.

Amount of energy delivered to cold storage from the load.

Amount of energy removed from cold storage by the chiller

Total energy losses from the cold storage subsystem.

The ratio of the auxiliary cooling subsystem load to thermal or electrical energy input.

Equivalent thermal energy supplied as a fuel source to the auxiliary thermodynamic conversion equipment.

Thermal energy removed from the air being cooled by the auxiliary thermodynamic conversion equipment.

Energy required to support the operation of the auxiliary thermodynamic conversion equipment; e.g., pumps, fans, etc. 
ACRONYM

ATCERJE

ATST

$A \times E$

AXF

$\therefore A \times T$

$\therefore B L$

CAE

CAF

CAREF
NAME

Auxiliary Rejected Energy

Average Cold Storage Temperature

Auxiliary Electric Fuel Energy to Load Subsystem

Auxiliary Fossil Fuel Energy to Load Subsystem

Auxiliary Thermal Energy to Load Subsystems

Building Load

SCS Auxiliary Electrical

Fuel Energy

ses Auxlliary Fossil Fuel Energy

Colleclur Array Efficiency
DEFINITION

Amount of energy intentionally rejected from thermodynamic conversion equipment as a by-product of its operation.

Average temperature of the cold storage medium.

Amount of electrical energy required as a fuel source for all load subsystems.

Amount of fossil energy required as a fuel source for all load subsystems.

Thermal energy delivered to all load subsystems to support a portion of the subsystem loads, from all auxiliary sources.

Sum of heat conducted through the building walls and ceilings, and heat convected through cracks, doors, and windows as air infiltration.

Amount of electrical energy provided to the SCS to be converted and applied to the SCS load.

Amount of fossil energy provided to the SCS to be converted and applied to the SCS load.

Ratlo of the collected solar energy to the incident solar energy. 
ACRONYM

CAT

$C D D$

CDE

$* C L$

CLAREA

CLEF

CLEFOP

CLS
NAME

SCS Auxiliary Thermal Energy

Cooling Degree-Days

Controlled Delivered Energy

Space Cooling Subsystem Load

Collector Array Area

Collection Subsystem Efficiency

Operational Collection Subsystem Efficiency

Solar Energy Contribution to Cooling Load
DEFINITION

Amount of thermal energy supplied to the SCS by the auxiliary equipment. For vapor compression units, it is CAE multiplied by compressor efficiency.

A rough measure of the cooling requirement. This performance factor is the difference between the mean daily temperature, TAVE, and $65^{\circ} \mathrm{F}$. If the mean is $65^{\circ} \mathrm{F}$ or less, cooling degree-days are zero.

Space heating intentionally delivered by the space heating subsystem including solar and auxiliary. This does not include heat losses from electric motors, pipes, storage, and other equipment.

Energy required to satisfy the temperature control demands of the space cooling subsystem.

The gross area of one collector panel multiplied by the number of panels in the array.

Ratio of the energy collected to the total energy incident on the collector array.

Efficiency when there is fluid in the collector loop.

The portion of the total cooling load which was satisfied by solar energy. 
COPE

SCS Operating Energy

COPEI

CS S AUX

$\div$ CSCEF

CSE

CSEO

* CSFR

CSOPE
Solar-Specific Operating Energy

Auxiliary Energy to ECSS

ECSS Solar Conversion Efficiency

Solar Energy to SCS

Energy Delivered from ECSS to Load Subsystems

SCS Solar Fraction

ECSS Operating Energy
Amount of electrical energy required to support the SCS operation (fans and pumps) which is not intended to directly affect the thermal state of the subsystem.

The operating energy necessary to the functioning of the solar energy portions of the SCS.

Amount of auxiliary energy supplied to the ECSS.

Ratio of the solar energy supplied from the ECSS to the load subsystems to the incident solar energy on the collector array.

Amount of solar energy delivered to the SCS.

Amount of energy supplied from the ECSS to the load subsystems (inr.luding any auxiliary energy supplied to the E(SS).

Percentage of the SCS load which is supported by solar energy.

Amount of energy used to support the ECSS operation (e.g., fans, pumps, etc.) which is not intended to affect directly the thermal state of the subsystem.

* Primary Performance factors 


\begin{tabular}{|c|c|c|}
\hline ACRONYM & NAME & DEFINITION \\
\hline CSRJE & ECSS Rejected Energy & $\begin{array}{l}\text { Amount of energy intention- } \\
\text { ally rejected or dumped } \\
\text { from the ECSS subsystem. }\end{array}$ \\
\hline CSVE & $\begin{array}{l}\text { SCS Electrical Energy } \\
\text { Savings }\end{array}$ & $\begin{array}{l}\text { Difference in the electrical } \\
\text { energy required to support } \\
\text { an assumed similar conven- } \\
\text { tional scs and the actual } \\
\text { electrical energy required } \\
\text { to support the demonstra- } \\
\text { tion sCs, for identical scs } \\
\text { loads. }\end{array}$ \\
\hline CSVF & SCS Fossil Energy Savings & $\begin{array}{l}\text { Difference in the fossil } \\
\text { energy required to support } \\
\text { an assumed similar conven- } \\
\text { tional scs and the actual } \\
\text { fossil energy required to } \\
\text { support the demonstration } \\
\text { scs, for identical scs loads. }\end{array}$ \\
\hline EHL & Equipment Heating Load & $\begin{array}{l}\text { Amount of energy supplied to } \\
\text { the space heating subsystem } \\
\text { equipment: solar, auxiliary } \\
\text { thermal, operating energy } \\
\text { converted to heat, and losses } \\
\text { from the space heating equip- } \\
\text { ment which contribute to } \\
\text { heating (the building heating } \\
\text { load less internal gains). }\end{array}$ \\
\hline GENOPE & $\begin{array}{l}\text { Power Generation } \\
\text { Operating Energy }\end{array}$ & $\begin{array}{l}\text { The electrical energy requir- } \\
\text { ed to operate the ECSS and } \\
\text { Rankine subsystems when they } \\
\text { are in the power generation } \\
\text { mode. }\end{array}$ \\
\hline HAE & $\begin{array}{l}\text { SHS Auxiliary Electrical } \\
\text { Fuel Energy }\end{array}$ & $\begin{array}{l}\text { Amount of electrical energy } \\
\text { provided to the SHS to be } \\
\text { converted and applied to the } \\
\text { SHS load. }\end{array}$ \\
\hline
\end{tabular}

TPimary Performance Factors 
HAF

HAT

HDD

HOPE

HOPE 1

HOURCT

HSE

HSEL

HSEM
NAME

SHS Auxiliary Fossil

Fuel Energy

SHS Auxiliary. Thermal Energy

Heating Degree-Days

SHS Operating Energy

Solar-Specific SHS Operáting Ellergy

Record Time

Solar Energy to SHS

Solar Energy Losses to Load

Measured Solar Energy to SHS
DEFINITION

Amount of fossil energy provided to the SHS to be converted and applied to the SHS load.

Amount of thermal energy provided to the SHS by the auxiliary SHS.

A rough measure of the heating requirement. This performance factor is the difference between the mean daily temperature and $65^{\circ} \mathrm{F}$. The medll is the aveituf of the minimum and maxlmum $t \in m-$ peratures for a given day. If the mean is 65\% or more, heating degree-days are zero.

Amount of energy required to support the SHS operation (which is not intended to be applied directly to the SHS load).

Operating energy necessary to the functioning of the solar energy portions of the SHS.

Count of hours elapsed from the start of 1977.

Amount of solar energy delivered to the SHS, including thermal losses from solai heated fluids.

Solar energy losses from storage and other equipment which heat the conditioned space.

Solar energy intentionally delivered to SHS by the distribution network. Does not include solar energy losses which also sometimes contribute to space heating. 


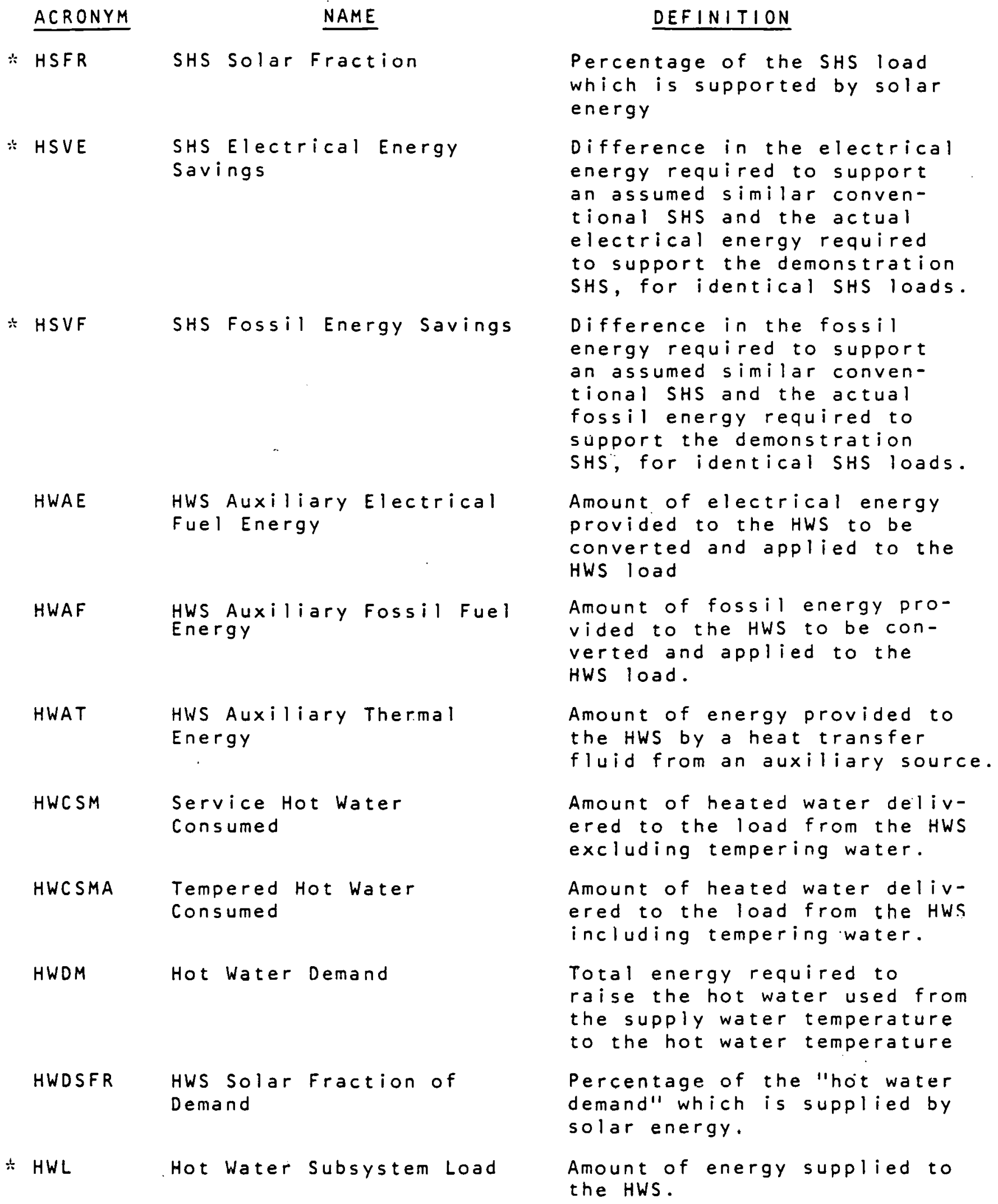

:T Primary Performance Factors 
ACRONYM

HWOPE

HWOPEI

Solar-Unique HWS Operating

HWSE

HWSE 1

* HWSFR

* HWSVE

* HWSVF

LINLOS

UUTVC

PARA Energy

Recirculation Loop Losses

Cuoling Produced

HWS Operating Energy

Solar Energy to HWS

Solar Energy to Preheat Tank

HWS Solar Froetion

HWS Electrical Energy Savings

HWS Fossil Energy Savings

$$
\text { Rankine Parasitic Power }
$$

\section{DEFINITION}

Amount of energy required to support the HWS operation which is not intended to be applied directly to the HWS load.

"Operating energy" necessary to the functioning of the solar energy portions of the HWS.

Amount of solar energy delivered to the HWS.

The amount of solar energy inpur to a preheat tank.

Percentage of the HWS load which is supported by soldi energy.

Difference in the electrical energy required to support an assumed similar conventional HWS and the actual electrical energy required to support the demonstration HWS, for identical HWS loads,

Difference in the fossil energy roquired to support on assumed similar cunventional HWS and the actual fossil energy required to support the demonstration HWS, for identical loads.

Thermal energy losses due to recirculation of hot water in a large building loop.

Space cooling provided by the air conditlonel, encrgy removed from the conditinned space.

Amount of auxiliary electrical energy supplied per unit time to the refrigerant pump and the Rankine subsystem controls. 
ACRONYM

PRELOS Preheat Tank Losses

PWRGEN Rankine Power Generated

PWRSVE Rankine Power Generation Savings

RANKOUT Rankine Turbine Output

REFF

RELH

ROPE

RSCAE
Relative Humidity

Rankine Operating Energy

Rankine Auxiliary Electric Used

\section{DEFINITION}

The difference between the input solar energy to a preheat tank and the output solar energy to the HWS tank. This includes losses and changes in internal energy.

Amount of electrical energy per unit time produced by the motor generator from the shaft power of the gas turbine.

The net output of the Rankine engines when operating in the power generation mode.

Mechanical energy developed at the output shaft of the Rankine engine gas turbine. Includes energy losses in the gearbox. This shaft output can drive a motor generator or an air conditioning compressor.

The ratio of RANKOUT to RSE. This percentage was developed from laboratory experimental data taken from gas turbines operating under typical conditions at the solar sites.

Average outdoor relative humidity at the site.

Amounl of electrical energy required to support the Rankine system. Includes energy for boiler feedwater pumping, cooling tower pumping, cooling tower fan and parasitics.

Amount of auxiliary electrical energy supplied to the motor generator for driving the air conditioning compressor. 
ACRONYM

NAME

RSCOP

RSE

RSRJE

* SE

SEA

$*$ SEC

$\div$ SECA

SEDF

* SEL

SEOP
Rankine Coefficient of Performance

Rankine Solar Energy Used

Rankine Energy Rejected

Incident Solar Energy

Incident Solar Energy on Array

Collector Solar Energy

Collected Solar Energy by Array

Diffuse Insolation

Solar energy to Load Subsys tems

Operational Incident Solar Energy
DEFINITION

The ratio of useful energy provided by the Rankine subsystem including the associated air conditioner to the operating and auxiliary energy input to the subsystem. Specifically, it is (OUTVC + PWRGEN)/(RSCAE + ROPE).

Amount of solar energy supplied to boil the refrigerant which drives the Rankine cycle gas turbine.

Amnunts of energy intentionally iejected through the cooling tower from the Rankine condenser and air conditioning condenser.

Amount of solar energy incident upon one square foot of the collector plane.

Amount of solar energy incident upon the collector array.

Amount of thermal energy added to the heat lransfer fluid for each square fool of the collector area.

Amount of thermal energy added to the heat transfer fluid by the collector array.

Amount of diffuse solar energy incident upon one square foot of a collector plane.

Amount of solar energy supplied by the ECSS to all load subsystems.

Amount of solar energy incident upon the collector array when the collector loop is active. 


\begin{tabular}{|c|c|}
\hline ACRONYM & NAME \\
\hline SFR & $\begin{array}{l}\text { Solar Fraction of Systen } \\
\text { Load }\end{array}$ \\
\hline SSSR & $\begin{array}{l}\text { System Solar Savings } \\
\text { Ratio }\end{array}$ \\
\hline STECH & $\begin{array}{l}\text { Change in ECSS Stored } \\
\text { Energy }\end{array}$ \\
\hline STEFF & ECSS Storage Efficiency \\
\hline STEI & $\begin{array}{l}\text { Energy Delivered to } \\
\text { ECSS Storage }\end{array}$ \\
\hline STEO & $\begin{array}{l}\text { Energy Supplied by ECSS } \\
\text { Storage }\end{array}$ \\
\hline STLOSS & Storage Loss \\
\hline STOCAP & Storage Capacity \\
\hline STPER & $\begin{array}{l}\text { Effective Heat Transfe } \\
\text { Coefficient }\end{array}$ \\
\hline
\end{tabular}

\footnotetext{
SYSCOP System Coefficient of Performance

* SYSL System Load
}

DEFINITION

Percentage of the system load which was supported by solar energy.

The ratio of the sum of the solar contributions to the system load minus the solarspecific system operating energy to the total system load.

Change in ECSS stored energy during specific time period.

Ratio of the sum of energy supplied by ECSS storage and the change in ECSS stored energy to the energy delivered to the ECSS storage.

Amount of energy delivered to ECSS storage by the collector array and from auxiliary sources.

Amount of energy supplied by ECSS storage to the load subsystems.

Total energy losses from the storage subsystem.

The volumetric storage capacity of the storage subsystem.

The overall heat transfer coefficient for the hot solar storage tank as measured for the month: ratio of storage loss to product of outside tank area, temperature difference across insulation, and number of hours in the month.

The ratio of the total solar energy delivered to the load to the sum of the solar operating energies.

Energy required to satisfy all desired temperature control demands at the output of all subsystems.

* Primary Performance Factors 


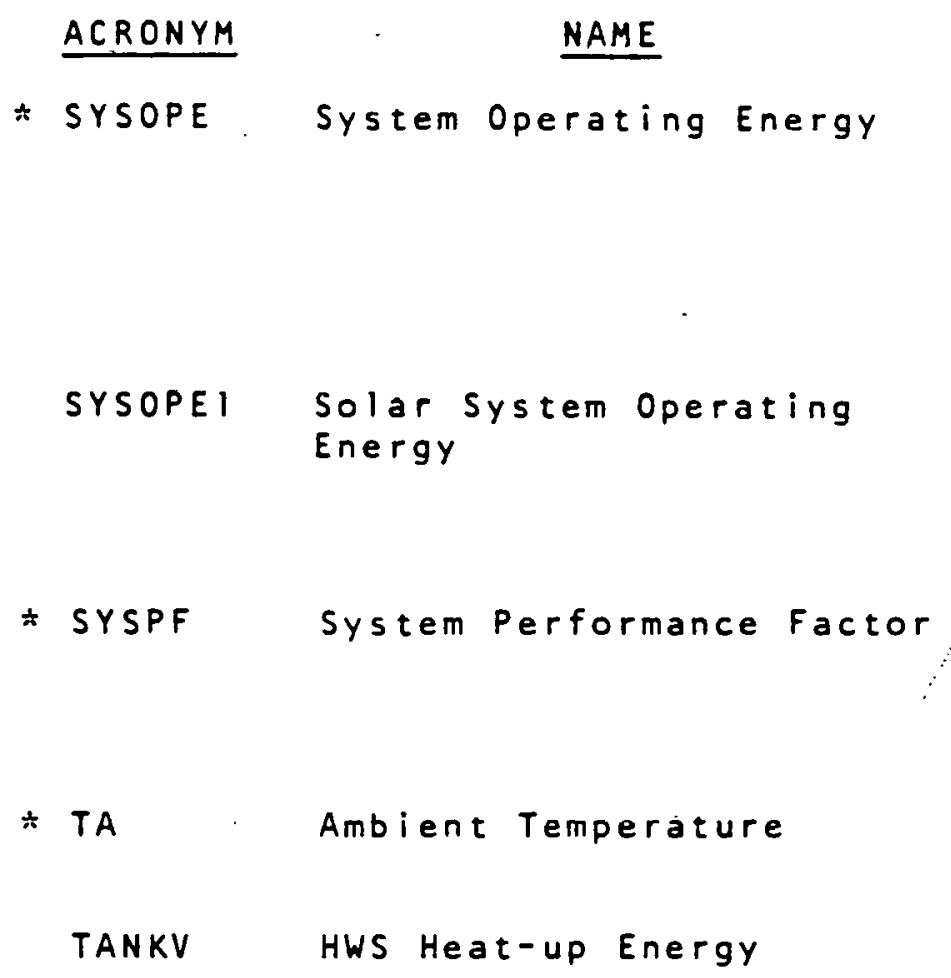

TAVE Averoge Daily Temperature

$\div$ T B

TCECOP TCE Coefficient of

TCE I

TCEL Performance

Building Temperature

TCE Thermal Input Energy

Thermodynamic Conversion Equipment Load
DEFINITION

Amount of energy required to support the system operation, including all subsystems, which is not intended to be applied directly to the system load.

Operating energy that is specifically used for the solar components of the system.

Ratio of the system load to the total equivalent fossil energy expended or required to support the system load.

Average temperature of the ambient air.

The energy required to heat all the water in the HWS tank from the cold water supply temperature to the hot water outlet temperature.

The average daily temperature as defined by the National Weather Service; 1.e., the average of the minimum and maximum temperatures for a given day.

Average temperature of the air in the controlled space of the building.

Coefficient of performance of the thormodynamic conversion equipment, typically, the ratio of equipment load to thermal energy input.

Equivalent thermal energy which is supplied as a fuel source to thermodynamic conversion equipment.

Controlled energy output of thermodynamic conversion equipment. 
ACRONYM

TCEOPE TCE Operating Energy

TCERJE TCE Reject Energy

TDA

$*$ TECSM

THW

TRANKC

TRANKS

TST

* TSVE
Rankine Condensing Water

Temperature

Rankine Solar Water Temperature

ECSS Storage Temperature

Daytime Average Ambient Temperature

Total Energy Consumed by System.

Service Hot Water

Temperature

Total Electrlcal Energy Savings
DEFINITION

Amount of energy required to support the operation of thermodynamic conversion equipment (e.g., pumps and fans).

Amount of energy intentionally rejected or dumped from thermodynamic conversion equipment as a by-product or consequence of its principal operation.

Average temperature of the ambient air during the daytime (during normal collector operation period).

Amount of energy demand of the system from external sources; sum of all fuels, operating energies, and collected solar energy.

Average temperature of the service hot water supplied by the system.

Temperature of the heat transfer fluid at the inlet to the condenser of the gas turbine subsystem.

Temperature of the heat transfer fluid at the inlet to the refrigerant boiler of the gas turbine.

Average temperature of the ECSS storage medium.

Difference in the estimated electrical energy required to support an assumed similar conventional system and the actual elecirical energy required to support the system, for identical loads; sum of electrical energy savings for all subsystems.

* Primary Performance Factors 
ACRONYM

* TSVF

WDIR

WIND
NAME

Total Fossil Energy

Savings

Supply Water Temperature

Wind Direction

Wind Velocity
DEFINITION

Difference in the estimated fossil energy required to support an assumed similar conventional system and the actual fossil energy required to support the system, for identical loads; sum of fossil energy savings of all subsystems.

Average temperature of the supply water to the hot water subsystem.

Average wind direction at the site.

Average wind velocity at the site.

Primary Performance Factor 
Absorptivity

Active Solar System

Air Conditioning

Ambient Temperature

Array

Auxiliary Energy

Auxiliary Energy Subsystem

Backflow

Backflow Preventer

Beam Radiation
The ratio of radiation absorbed by a surface to the total radiated energy incident on that surface.

A system in which a transfer fluid (liquid or air) is circulated (by pump or fan) through a solar collector.

Popularly defined as space cooling; more precisely, the process of treating indoor air by controlling the temperature, humidity, and distribution to maintain specified comfort conditions.

The surrounding air temperature.

An assembly of a number of collector elements, or panels, into the solar collector for a solar energy system.

In solar energy terminology, the energy supplied to the heating or cooling load from other than the solar source, usually from a conventional heating or cooling system. Excluded are operating energy, and energy which may be supplemental in nature but does not have the auxiliary system as an origin; e.g., energy supplied to the space heating load from the external environment by a heat pump.

In solar energy terminology, the auxiliary energy system is the conventional heating and/or cooling equipment used as a supplement or backup to the solar system.

Reverse flow.

A valve or damper installed in a pipe or duct to prevent reverse flow of the fluid.

Radiated energy received directly, not from scattering or reflecting sources. 
Collected Solar Energy

Collection Subsystem

Collector Array Efficiency

Collector Conversion

Efficiency

Concentrating solar

Collector

Conditioned Space

Control system or

Subsystem

Cooliny Degree-Doys

Cooling Tower

Diffuse Radiation

Drainback

Draindown.
The thermal energy added to the heat transfer fluid by the solar collector.

The assembly of components that absorbs incident solar energy and transfers the absorbed thermal energy to a heat transfer fluid.

Same as Collector Conversion Efficiency. Ratio of the collected solar energy to the incident solar energy. (See also Operational Collector Efficiency.)

Ratlo of thermal energy outpul to solar energy incident on the collector array.

A solar collector that concentrates the energy from a larger area onto an absorbing element of smaller area.

The space in a building in which the air is heated or cooled to maintain a desired temperature range.

The assembly of electric, pneumatic, or hydraulic, sensing, and actuating devices used to control the operating equipment in'a system.

The sum over a specified period of time of the number of degrees the mean daily temperature is above $65^{\circ} \mathrm{F}$.

A heat exchanger that transfers waste heat to outside ambient air.

soler rodlatiun which is scottered by air molecules, dust, or water droplets and incapable of being focused.

Automatic dralning of the collogtor orray and piping to storage each time the collector pump shuts off.

A system equipped with automatic or manual values which drain the solar collectors and collector piping to prevent freezing in the event of cold weather. 
Duct Heating Coil

Effective Heat Transfer Coefficient

Energy Gain

Energy Savings

Expansion Tank

F-Chart

Fixed Collector

Flat-Plate Collector
A liquid-to-air heat exchanger in the duct distribution system.

The heat transfer coefficient, per unit plate area of a collector, which is a measure of the total heat losses per unit area from all sides, top, back, and edges.

The thermal energy gained by the collector transfer fluid. The thermal energy output of the collector.

The estimated difference between the fossil and/or electrical energy requirements of an assumed conventional system (carrying the full measured load) and the actual electrical and/or fossil energy requirements of the installed solar-assisted system.

A tank with a confined volume of air (or gas) whose inlet port is open to the system heat transfer fluid. The pressure and volume of the confined air varies as the system heat transfer fluid expands and contracts to prevent excessive pressure from developing and causing damage.

A computer program developed by the University of Wisconsin Solar Energy Laboratory, which calculates solar heating system performance and economics.

A solar collector that is fixed in position and cannot be rotated to follow the sundaily or seasonably.

A solar energy collecting device consisting of a relatively thin panel of absorbing material. A container with insulated bottum and $s$ ides and covered with one or more covers transparent to visible solar energy and relatively opaque to infrared energy. Visible energy from the sun enters through the transparent cover and raises the temperature of the absorbing panel. The infrared energy reradiated from the panel is trapped within the collector 
Flat-Plate Collector (Continued)

Focusing Collector

Fossil Fuel

Glazing

Heat Exchanger

Heat Transfer Fluid

Heating Degree-Days

Incidence Angle

Incident Solar Energy

Insolation

Instantaneous Efficiency because it cannot pass through the cover. Glass is an effective cover material (see Selective Surface).

A concentrating type collector using parabolic mirrors or optical lenses to focus the energy from a large area onto a small absorbing area.

Petroleum, coal, and natural gas derived fuels.

In solar energy terminology, the transparent covers used tio reduce energy losses from a collector panel.

A device used to transfer energy from one heat transfer fluid to another while maintaining physical sogregation of the fluids. Normally used in systems to provide an interface between two different heat transfer fluids.

The fluid circulated through a heat source (solar collector) or heat exchanger that transports the thermal energy by virtue of its temperature.

The sum over a specified period of time of the number of degrees the mean daily temperature is below $65^{\circ} \mathrm{F}$.

The angle between the line to a radiating source (the sun) and a line normal to the plane of the surface being irradiated.

The amount of solar energy irradiating a surface taking into account the angle of incidence. The effective area receiving energy is the product of the area of tho surfare times the cosine of the angle of incidence.

Incoming solar radiation

The efficiency of a solar collector

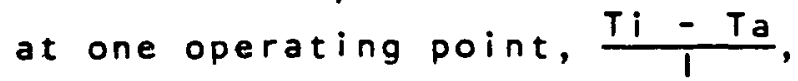
under steady-state conditions (see operating Point). 


\author{
Instantaneous Efficiency \\ Curve
}

Load

Manifold

Microclimate

Nocturnal Radiation

Operating Energy

Operating Point

Operational Collector Efficiency

Outgassing
A plot of solar collector efficiency against operating point, $\frac{\mathrm{Ti}-\mathrm{Ta}}{1}$, (see Operating Point).

That to which energy is supplied, such as space heating load or cooling load. The system load is the total solar and auxiliary energy required to satisfy the heating or cooling requirements.

The piping that distributes the transport fluid to and from the individual panels of a collector array.

Highly localized weather features which may differ from long-term regional values due to the interaction of the local earth's surface with the atmosphere.

The loss of thermal energy by the solar collector to the night sky.

The amount of energy (usually electrical energy) required to operate the solar and auxiliary equipments and to transport the thermal energy to the point of use, and which is not intended to directly affect the thermal state of the system.

A solar energy system has a dynamic operating range due to changes in level of insolation (1), fluid input temperature ( $T i)$, and outside ambient temperature ( $\mathrm{Ta}$ ). The operating puint is defined as:

$$
\frac{T i-T a}{1}\left(\frac{O F \times h r \times f t^{2}}{B T U}\right)
$$

Ratio of collected solar energy to incident solar energy only during the time the collector fluid is being circulated with the intention of delivering solar-source energy to the system.

The emission of $g a s$ by materials and components, usually during exposure to elevated temperature, or reduced pressure. 
Passive Solar System

Pebble Bed (Rock Bed)

Reflected Radiation

Rejected Energy

Retrofit

Selective Surface

Sensor

Solar Conditioned Space

Solar Fraction

Solar Savings Ratio

Storage Efficiency, $n_{s}$

Storage Subsystem
A system which uses architectural components of the building to collect, distribute, and store solar energy.

A space filled with uniform-sized pebbles to store solar-source energy by raising the temperature of the pebbles.

Insolation reflected from a surface, such as the ground or a reflecting element, onto the solar collector.

Energy intentionally rejected, dissipated, or dumped from the solar systom.

The addition of a solar energy system to an existing structure.

A surface that has the ability to readily absorb solar radiation, but reradiates little of it as thermal radiation.

A device used to monitor a physical parameter of a system, such as temperature or flow rate, for the purpose of measurement or control.

The area in a building that depends on solar energy to provide a fraction of the heating and cooling needs.

The fraction of the total load supplied by solar energy. The ratio of solar energy supplied to loads divided by total load. Often expressed as a percentage.

The ratio of the solar energy supplied to the load minus the solar system opcrating energy, divided by the system load.

Measure of effectiveness of transfer of energy through the storage subsystem taking into account system losses.

The assembly of components used to store solar-source energy for use during periods of low insolation. 
Stratification

System Performance Factor

Ton of Refrigeration

Tracking Collector

Zone
A phenomenon that causes a distinct thermal gradient in a heat transfer fluid, in contrast to a thermally homogeneous fluid which results in the layering of the heat transfer fluid, with each layer at a different temperature. In solar energy systems, stratification can occur in liquid storage tanks or rock beds, and may even occur in pipes and ducts. The temperature gradient or layering may occur in a horizontal, vertical, or radial direction.

Ratio of system load to the total equivalent fossil energy expended or required to support the system load.

The heat equivalent to the melting of one ton $(2,000$ pounds $)$ of ice at $32^{\circ} \mathrm{F}$ in 24 hours. A ton of refrigeration will absorb 12,000 BTU/hr, or 288,000 BTU/day.

A solar collector that moves to point in the direction of the sun.

A portion of a conditioned space that is controlled to meet heating or cooling requirements separately from the other space or other zones. 